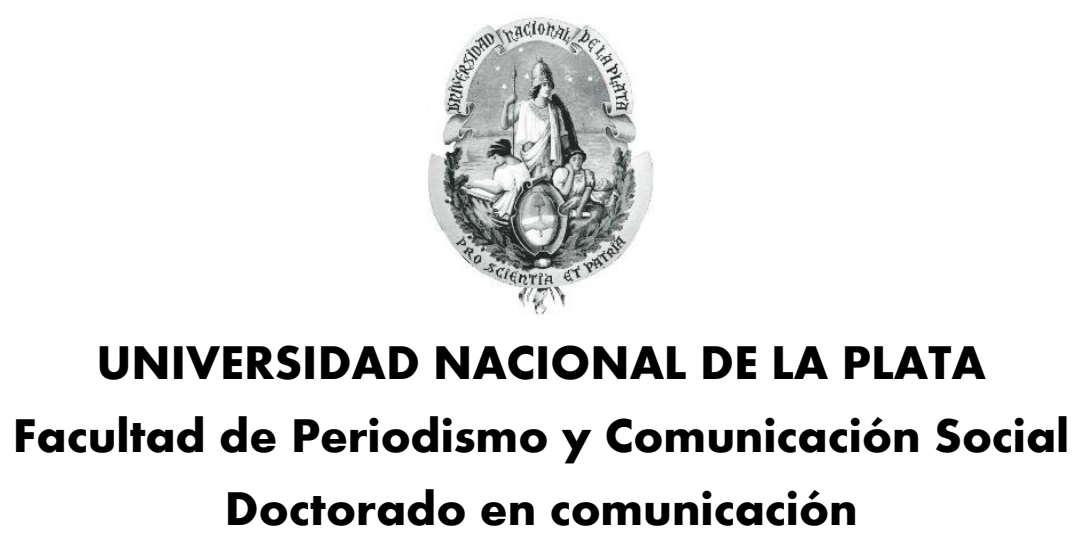

Trabajo de tesis para optar al título de DOCTORA EN COMUNICACIÓN

\title{
Experiencia, ciudad e identidad en torno a la organización barrial Tupac Amaru de San Salvador de Jujuy
}

Director: Alejandro Kaufman

Co-directora: Alejandra García Vargas

Doctoranda: Melina Gaona

Cohorte 2011 


\section{Agradecimientos}

Quiero agradecer en principio a mis directores. A Alejandro Kaufman por haber cumplido con su tarea de director de un modo en el que solo él puede lograrlo, incidiendo en cada detalle sin procurarlo, como maestro desde lo más humano de sus reflexiones.

A Alejandra García Vargas, cuya labor en esta tesis y a lo largo de toda mi formación académica ha sido clave. Inspiradora y motivadora, con cada expresión de aliento y con palabras agudas ha sabido guiar gran parte de la tarea que hoy se ve plasmada en esta investigación.

A Verónica Ficoseco, compañera y complementariedad en cada debate. Quiero agradecerle porque informalmente le cabe el rol de tercera directora por el nivel de compromiso desinteresado que ha manifestado en cada momento de mi investigación. Su templanza, su cariño y su consejo fueron y son matiz orientador de mi persona en estos años.

A Andrea Noelia López, Andy, que es una hermana que me dio la vida y el cable a tierra necesario. El resultado de esta investigación se inició de manera conjunta y con ella aprendí día a día a 'ponerle el cuerpo' a las militancias. Seguro la vida nos seguirá encontrando en cuantos rumbos tomemos.

A Gonzalo Zubia, quien acompañó de manera cotidiana el transcurso por el doctorado y con quien compartí debates intensos y caldeados, a la par de carcajadas y momentos entrañables.

A Moncho Burgos, mentor compinche quien es un pilar fundamental de mi formación personal y profesional, cuya ética y valor por la comunicación, la política (y el fútbol) me han ayudado a orientar caminos y crecer en muchos ámbitos y terrenos.

A lxs maestrxs que tuve en la carrera de comunicación en la Universidad Nacional de Jujuy, quienes luchan día a día desde la universidad pública de frontera por transformar la realidad de miles, que como yo, nos sentimos inspiradxs por su labor para seguir en la tarea.

A lxs docentes del Doctorado, quienes me brindaron una experiencia inigualable por la calidad de cada uno de los seminarios, corriéndose de los esquemas disciplinares para enseñarnos con la mirada puesta en lo que los escenarios nos requieren.

Al Conicet que, en una apuesta por el fortalecimiento federal de investigadores y docentes, me brindó la posibilidad de formarme. Sin su financiamiento estipulado para el desarrollo profesional de jóvenes del interior del país esta tesis no hubiera sido posible. A la Universidad Pública por la cual transité y transito como estudiante, docente e investigadora. Considero que no es sino acompañando lo social desde una posición colaborativa crítica por parte de la ciencia y de la educación que se pueden propiciar cambios medulares en la sociedad.

A lxs amigxs y compañerxs con quienes en muchos momentos discutí partes de este y otros intereses: a Luis Urtubey y a lxs grandes amigxs que me dejó la UNJu; a Bárbara Biblao y a toda la oficina 34 de la UNQ; a Cleopatra Barrios y a todxs lxs compañerxs que me ha dado el doctorado; a lxs Vectores. A Edit y Felipe, amigos que me dio esta hermosa ciudad. A la comitiva colombiana que me recibió y fue mi familia en estos años.

A mis padres, a quienes les dedico esta tesis. A mi hermano, Sebastián. A mi abuelo. A toda mi familia, quien supo acompañarme desde el amor y el entendimiento en cada uno de mis nuevos retos. 


\section{ÍNDICE}

1. 1. Planteos iniciales del recorrido

1. 2. Partes y capítulos de la tesis. Aproximación conceptual 16

1.3. Antecedentes sobre organizaciones sociales y sobre la organización barrial Tupac Amaru 21

1.3.1. Presentación. Marco global introductorio sobre movimientos sociales 21

1.3.2. Antecedentes a nivel nacional sobre organizaciones sociales 22

1.3.3. Antecedentes en Jujuy y sobre la Tupac Amaru 25

1.3.4. Estudios con perspectiva de género 27

PRIMERA PARTE. CLAVES DE LECTURA

2. MARCO METODOLÓGICO 30

2.1. Presentación 30

2.2. Construcción del objeto de estudio 32

2.3. Etnografía multi-situada 35

2.3.1. Registro múltiple en soportes mediáticos 37

2.3.2. Observación participante y entrevistas 41 
3. 1. Cohabitar. Espacios y ciudades 53

3. 2. La ciudad de San Salvador de Jujuy y su dimensión simbólica 65

4. LA TUPAC AMARU. EL FAUSTO JUJEÑO 82

4. 1. Surgimiento y estabilización 82

4. 2. La construcción de la (otra) ciudad a partir del fenómeno Tupac 93

4. 3. Enraizar la lucha. La educación, la salud y las obras en el centro de la ciudad: la sede central y los galpones recuperados 101

4. 4. Las cooperativas. Lxs obrerxs 106

4. 5. Tupaqueras 112

4. 6. El cantri 120

4. 7. El country. De la apetencia por la seguridad 124

SEGUNDA PARTE. APROXIMACIONES DESDE LA CRÍTICA CULTURAL 132 
5. 1. Traducciones teóricas posibles acerca de la multitud

5. 2. Acción, reacción; presencia y violencia

5. 3. Uniformadxs y dirigidxs. Ovejas, esclavxs y

el ejército comandado por Milagro Sala 143

5. 4. La escena festiva. Los reyes magos y el día del niño 152

6. CONFLUENCIA DE SENTIDOS EN LA OBRA ARQUITECTÓNICA URBANA DE LA TUPAC AMARU 158

6.1. Presentación 159

6.2. Breve descripción de la escena. La experiencia del panorama público 162

6.3. Observaciones sobre la obra 164

6.4. Replicar. La copia y la fantasmagoría 166

6.5. Indigenizar la ciudad 167

6.6. Jugar. Los juegos del parque 169

6.7. Veranear. La pileta y las configuraciones de la inclusión 170

6.8. Mostrar. Derroche como exhibición 172

6.9. Deshacer. El género y los cuerpos visibles 173

6.10. Satirizar e ironizar. Reapropiación simbólica y apuesta camp 175

7. DEMANDAS ÉTNICAS EN EL CONTEXTO MULTICULTURAL 177 
7.2. Comunidad, organización y demandas al Estado

7.3. “¿La Tupac junto a la presidenta Cristina!”. Ciudadanía y representación indígena 183

7.4. La marcha de los pueblos originarios en el bicentenario 191

7.5. Pluralismo y Multiculturalismo 192

7.6. Indígenas ¿rurales? 195

8. MARCHA DEL ORGULLO. REPERTORIOS DE VISIBILIDAD DE LA DIVERSIDAD 200

8.1. Presentación 200

8.2. Políticas de la identidad y registro de la diferencia 202

8.3. Contextualización histórica de la consigna del Orgullo 207

8.4. Disputa con los símbolos hegemónicos locales 211

8.5. Las imágenes de las reinas. La ilusión mujer 215

8.6. Experiencia y autoconciencia 218

9. CONCLUSIONES 223

10. REFERENCIAS BIBLIOGRÁFICAS 242 


\section{INTRODUCCIÓN}

\subsection{Planteos iniciales del recorrido}

Esta es una tesis sobre la Tupac Amaru. De esta manera fue definida habitualmente a lo largo de varios años tanto por mí, como por quienes estuvieron y acompañaron el proceso de investigación y reflexión. Esta primera expresión suena como una mención dispersa, gris o indefinida de algo que pretende ser tan preciso y sistemático como una tesis doctoral. Sin embargo, para comprender cuál es el objeto de esta investigación es necesario asumir que la Tupac Amaru es una excusa, un punto de partida a partir del cual podemos construir un cúmulo congruente de problematizaciones. Para ello se busca considerar a la experiencia territorial construyéndola analíticamente como una escena ${ }^{1}$ en el presente $^{2}$, y generar un análisis crítico a partir de imágenes de aquello que puede reconocerse como parte del movimiento social, en vinculación con diferentes articulaciones hegemónicas rastreables en el contexto local. Esta exploración se hace a partir de un vasto repertorio discursivo sobre el cual se dispone una crítica cultural orientada a desentramar las vías por las cuales se entablan voluntades de forma y reparto

${ }^{1}$ Aquello que llamamos escena se alza a partir de una interrogación que pretende "abarcar materiales [que carecen] de una formalización acabada y explorar los pliegues de sensibilidad de una trama cultural hecha no sólo de discursos constituidos, sino también de discursos flotantes, de difusas ideologías prácticas, de gestualidades semi-esbozadas, de simbolizaciones incompletas (Richard, 2001: 139). También apelamos a la definición de escena que da Silvia Delfino, y retoma Leavi (2013), en tanto ámbito "donde se tensan lenguajes, prácticas y culturas, a partir de modos diversos de intervención (...) cultural y política" (2013: 4).

${ }^{2}$ Se establece que el presente no cesa de fluctuar entre un pasado desde donde se acumula y un futuro hacia donde se proyecta un porvenir transformador (Cangi, 2013). 
de sentidos asignados.

La tesis establece en el pivote de la Tupac Amaru una serie de debates vinculados a un compendio cohesivo de problematizaciones: el modo en el que se cimientan, estructuran y desplazan desigualdades históricas entre distintos sectores de la sociedad jujeña; los relieves de las operaciones que constituyen a la diferencia a nivel local; las dinámicas en las que se libran las relaciones de poder y la manera en que se articula la hegemonía ${ }^{3}$ en el presente en Jujuy; el encausamiento por el que confluyen y se nombran demandas históricas locales que se canalizan por la vía del sujeto colectivo del movimiento; los procesos de agenciamiento y empoderamiento ${ }^{4}$ de una parte de los sectores populares urbanos; las expresiones materializadas que aportan indicios acerca del deseo colectivo; y la politización de la vida cotidiana y la conflictividad de lo comunitario como horizonte.

La experiencia, la identidad y los espacios de ciudad no se presentan en esta investigación como series o regiones analíticas aisladas o segmentos que distinguimos separadamente al interior del umbral problemático construido. En cambio, funcionan como un paraguas

${ }^{3}$ La noción de hegemonía rodea constantemente los planteos de la tesis. En una aproximación inicial podemos presentar una definición clásica que la concibe como "todo un cuerpo de prácticas y expectativas en relación con la totalidad de la vida. (...) Es un vívido sistema de significados y valores -fundamentales y constitutivos- que en la medida en que son experimentados como prácticas parecen confirmarse recíprocamente" (Williams, 2009: 151). También podemos aportar los desarrollos de Laclau (2011) en torno de las dimensiones de la hegemonía, asumiendo que en ella es constitutiva la desigualdad de poder, que se concreta cuando los intereses de un sector particular se presentan como objetivos universales de la comunidad, y que esta concreción se da a partir de la representación de que este particular cubre significantes vacíos que circulan en el campo social.

${ }^{4}$ Hablamos de empoderamiento recogiendo las complejidades de un concepto que supone que un grupo asume una posición de ejercicio de poder en relativa elevación por sobre otros, exhortándolos casi indefectiblemente a la reproducción de quienes los ejercían sobre ellos (Segato, 2011). Hablamos de empoderarse también asumiendo que el reconocimiento de sus intereses nubla u ocluye, obtura las demandas del resto de los sectores populares en Jujuy. La condición del empoderamiento de un grupo es su jerarquización por sobre otros. 
conceptual, o como espirales de contacto permanente con la intención de desmoldarlos de la abstracción teórica de la que surgen para modularlos de acuerdo con la atracción y refracción empírica concreta. Queda establecido que los tres conceptos que inauguran la temática de esta tesis operan como un carril amplio por el que se buscan recorrer las complejidades de la desigualdad y la diferencia, los modos de opresión y empoderamiento, los procesos de dominación y las instancias de agencia, a partir de la materialización de una serie específica de prácticas y sentidos que los definen como formación social específica (Hall, 2010). En este sentido, las intersecciones de la diferencia se asumen como parte de la reconstrucción particular en el contexto jujeño.

Estos procesos simbólicos se han sostenido como campo de disputa permanente en la vida urbana en San Salvador de Jujuy. En este caso, buscamos observarlas de manera puntual a partir del modo en el que "se nos presenta" la Tupac Amaru en Jujuy. Así, el fenómeno analizado es concebido como un punto de fuga dentro de procesos históricos de relaciones de poder en la ciudad. Se elige a este colectivo porque, consideramos, aúna muchos de los procesos que nos interesan discutir, y lo hace atravesando al menos los últimos quince años de la historia local. El caso, entonces, no se elige el azar, sino que se le adjudica la particularidad de ser representativo de un fenómeno de interés sociopolítico o la confluencia de muchos de ellos. Si bien es un proceso singular, le cabe la coincidencia observable de toda esta serie de desarrollos que se vivieron en los últimos años en Argentina y, específicamente, en Jujuy. No buscamos en ningún punto extrapolar, ni generalizar a partir de lo planteado.

El fenómeno se presenta como una experiencia singular instituyente. Consideramos que esta apuesta social tiende a romper barreras de las segmentaciones sociales, lo que genera una 
turbación colectiva ante la falta de aprehensión de ciertos procesos. Estos quiebres no pueden ser del todo observados si no se apela a un ruptura de tabiques disciplinares, y de miradas temáticas y conceptuales. Por ello, es necesario destacar en este punto que la tesis se mueve cognitivamente ante los requerimientos de un fenómeno de estas características. Sus instancias de difícil traductibilidad e inteligibilidad desde lo académico, se manifiestan culturalmente en un abierto rechazo dadas sus complejidades y matices.

El presente recorrido admite la imposibilidad de un análisis sobre una totalidad ${ }^{5}$. El planteo que aquí se hace procura una aproximación fragmentaria que permita agudizar la mirada y asumir la objetividad a partir de la presencia del sujetx en el reconocimiento y apelación a perspectivas colectivas, parciales y con intereses (Haraway, 2004). En tanto nos incorporamos a la crítica cultural mediante un conjunto variable de prácticas reflexivas y de escritura, la búsqueda explora en "pliegues de sensibilidad" hechos de discursos flotantes, de simbolizaciones incompletas y de sensibilidades (Richard, 2001). La combinación de ambas pretensiones -la fragmentariedad como inscripción responsable para la crítica cultural- nos convoca a ensayar una forma rapsódica (Barthes, 2005) en la que la presentación se vale de un discurso compuesto de rasgos, momentos, imágenes y conceptos que se intersectan y cruzan de manera internamente coherente ${ }^{6}$.

No intentamos operacionalizar el conflicto en busca de confirmar premisas, sino como

${ }^{5}$ Nos alejamos de una noción de sociedad como una totalidad. Esto es una lógica paradigmática dominante de época que reconocemos en muchas de las influencias teóricas de la tesis (Richard, 2001; Massey, 2012; Laclau, 2011; Guattari y Rolnik, 2006; Foucault, 2002).

${ }^{6}$ Barthes (2014) refiere a este armado como retazos de discursos que se presentan como figuras, que se dan en un orden no determinado pero sí distribucional, con referencias montadas a partir de trozos de origen diverso. "No invoco garantías, evoco solamente, por una suerte de saludo dado al pasar, lo que seduce, lo que convence, lo que da por un instante el goce de comprender (¿de ser comprendido?)” (Id.: 22). 
condición experimental analítica de contraste y apertura; nos valemos de la heterodoxia en las herramientas metodológicas de búsqueda; y aprovechamos distintas vertientes teóricas en el cruce entre cultura y política incorporando elementos característicos para combinarlos en una composición mixta de interpretaciones. Esta variedad de prácticas logra una consistencia teórica crítica que pretende armar un mapa hermenéutico a partir cada uno de los puntos del análisis.

Si bien se resigna inscribir la investigación de lleno en alguna de las esferas analíticas a las que recurrimos, apostamos a la productividad de abordar la escena de esta manera. Los antecedentes directos y el acervo teórico sobre los que se sostiene lo que exponemos se establece en la confluencia de grandes áreas o formas de conocimiento ${ }^{7}$, que disponen un movimiento entre los estudios culturales y la teoría crítica; los feminismos de la tercera ola, los feminismos latinoamericanos y los feminismos post-feministas; el post-estructuralismo y el postmarxismo; y los estudios postcoloniales, de subalternidad y el deconstruccionismo. Esta enumeración no hace más que guiar los bordes del territorio analítico sobre el que nos movemos de manera instersticial a fin de aportar, al menos de manera lateral, a cada uno de ellos. Este movimiento entre líneas desemboca en una tesis en la que se evidencian momentos en los que nos aproximamos más a unas vertientes que a otras, o se hacen más marcadas las voces de una línea que de otra. Esto lleva también a que muchas instancias se expongan de manera más incipiente y otras ahonden en desarrollos de mayor profundidad; y que algunos momentos se presenten

${ }^{7}$ No es objeto de la tesis hacer una genealogización de cada uno de los conceptos que se utilizan. Se tienen presentes los análisis de la historicidad de cada uno de los conceptos, de la acumulación histórica que portan cada uno de ellos y de su relación epistemológica, pero no hacen parte de los intereses de desarrollo en esta investigación puntual. La explicitación de Adorno acerca de la satisfacción de un recorrido ondulante de este tipo viene a convalidar nuestra posición: "No empieza por Adán y Eva, sino por aquello de que quiere hablar; dice lo que a su propósito se le ocurre, termina cuando él mismo se siente llegado al final, y no donde no queda ya resto alguno: así se sitúa entre las 'di-versiones"” (Adorno, 1962: 12). 
como secuencias descriptivas ${ }^{8}$ y otros con evidentes dimensiones argumentales. Cada una de las escalas planteadas se supedita a la pregunta inicial sobre la conflictividad de la diferencia en el contexto urbano y su desenvolvimiento a partir de los movimientos multitudinarios.

Todos estos planteos se ligan en el análisis en tanto el movimiento social y la producción social a partir del conflicto son preguntas inmanentes a lo comunicacional, dado que el interés está orientado la transformación, la opacidad o el desacuerdo, y las articulaciones históricas entre los materiales y sus condiciones de producción: lo que a grandes rasgos podríamos distinguir como el carácter activo y movilizante de lo simbólico y sus horizontes.

La búsqueda de estos horizontes simbólicos a partir de la multi-polaridad interpretativa que se programó no conduce hacia una intención neutral ni mucho menos. Al contrario, la teoría se procura con voluntad de intervención a partir de una posición ideológica y una situación asumidas. Con una problematización elaborada a partir de esta posición, la construcción fragmentaria parece la vía más adecuada.

Armada esta primera aproximación epistémica sobre la investigación, podemos adentrarnos en una proposición inicial acerca del montaje discursivo y los materiales analíticos construidos. Para explicitarla incorporamos una figura, como es la del Calibán, por una doble vía que se sostendrá como rúbrica permanente en la tesis ${ }^{9}$. Primeramente, en el sentido que construye

${ }^{8}$ De todas maneras, en la distinción entre descripción y argumentación no se desconoce la semejanza en la parcialidad de la interpretación de quien observa. La discriminación mencionada opera solo como abstracción analítica.

${ }^{9}$ Aquí aludimos puntualmente a las escenas de La Tempestad (Shakespeare, 2005) que movilizaron fructíferas consideraciones acerca del lugar del sujeto dominado y colonizado (en la relación entre Calibán y Próspero), el rol del aprendizaje de la palabra y el lenguaje, y la vía resistente o de rebeldía ("me enseñaste a hablar, y mi provecho es que sé maldecir ¡La peste roja te lleve por enseñarme tu lengua!”). 
Achugar (2000), retomando a Fernández Retamar (1971), en la presentación de un pensamiento local (latinoamericano) como un discurso en forma de balbuceo, lo que dictaría una aparente imposibilidad de generación de un discurso mayor que, en cambio, se daría como mala mímica de teorías convalidadas ${ }^{10}$. Ante esto, el autor plantea si acaso no puede tratarse de un discurso con su propia sistematicidad proponiendo el acogimiento de una situación de enunciación que no se rige de manera estricta por criterios forjados exteriormente y que se asienta sobre tal "balbuceo teórico" como estrategia escritural legítima. En función no solo de una historia local y concreta, sino de un posicionamiento dentro de dicha historia, dentro de un horizonte ideológico situado, como con el Calibán, encontramos en el uso de la palabra un vehículo de intervención sobre el propio destino académico.

Por otro lado, es este personaje literario el que nos permite adelantar una primera figura acerca del sujeto social retomado en la tesis. Más allá de una lectura inicial lineal que asocia al sujeto de posición subalterna con características traducibles a la situación del conquistado, subyugado y oprimido, recaemos sobre ella para incorporar la lógica de que lo que vemos de él es "la mirada" de quien ante él se encuentra. No oponemos aquí al Calibán y a Próspero ${ }^{11}$, sino que reconocemos en esta presentación antagónica que el vínculo se manifiesta a partir de la radical alteridad con la que uno construye al otro, y que esta condición de desacuerdo sienta las bases

${ }^{10}$ La convalidación científica y las pretensiones de legitimidad en los discursos imperantes han sido ampliamente criticados, entre otras instancias, por la puesta en cuestión de la auto-adjudicación de la transparencia y neutralidad en un pensamiento de raíz androcéntrica y blanca (Harding, 1993; Haraway, 2004; Curiel, 2011), y que más bien, a contracara del revestimiento de autoridad con que cuentan los expertos en la actualidad, la palabra intelectual debe ubicarse marginal o exiliadamente del poder (Said, 1996).

${ }^{11} \mathrm{O}$, para el caso, a la presencia de Ariel, representante de la cultura elevada y lo espiritual, como otro contraste. 
para las instancias opresivas y hostiles subsiguientes ${ }^{12}$. La exposición de esta imagen se hace en tanto ella condensa una atmósfera rígida que se mantiene transversalmente a lo largo de lo postulado en la tesis.

\subsection{Partes y capítulos de la tesis. Aproximación conceptual}

Como una última parte de esta introducción se genera un recorrido por antecedentes teóricos como lecturas que hacen al cúmulo teórico con el que se aborda esta tesis. Entre ellos circulan lecturas de sistematización sobre los movimientos sociales en contextos contemporáneos. Seguidamente, si bien a nivel nacional es vasto el ámbito de desarrollo académico acerca de la acción colectiva en las últimas dos décadas, nos abocamos a hacer un recorrido sucinto sobre aquellas líneas que consideramos más fructíferas en diálogo con nuestra propia investigación con especial énfasis en estudios que perciben la conflictividad productiva de la aproximación popular a lo político, estudios con perspectiva de género y etnografías en el campo popular politizado. Así también, disponemos introductoriamente los estudios llevados a cabo acerca de la Tupac Amaru como sujeto político, notando que las preguntas más recurrentes refieren a su relación con el Estado y a su rol de intermediario de intereses populares.

La primera parte de la tesis reúne capítulos que pueden establecerse como las claves de lectura de la investigación. La explicitación del método, la descripción crítica de la coyuntura con la que nos encontramos y la reconstrucción histórico cultural del sujeto sientan las bases para el

\footnotetext{
${ }^{12}$ Esta lectura sobre la obra teatral está basada sobre todo por lo planteado por Fernández Retamar (1971).
} 
estudio realizado.

En el capítulo metodológico se deja explícita la reconstrucción del sujeto de análisis y se deja en claro que su opacidad responde a una condición inherente dado su carácter simbólico. Por otro lado, se enumeran de forma organizada los recorridos trazados a partir de las herramientas de recolección elegidas, entre los recursos de la etnografía clásica y la etnografía multi-situada. Por último, en una primera instancia de aproximación empírica, se logra una reconstrucción periódica del fenómeno de análisis a partir de un eje problemático que cruza el crecimiento multitudinario con la conflictividad en la visibilidad.

En el segundo capítulo se presenta la abstracción analítica mediante la cual abordamos los espacios, a fin de mensurar la radicalidad de lo espacial en la condición de cohabitabilidad con la diferencia. Esto se emprende, así también, a fin de dar cuenta de que los espacios son una instancia primaria de materialización en la estructuración de las relaciones desiguales. Finalmente, incorporamos una serie de lecturas acerca del modo en que se dan y se dieron esas relaciones de poder para construir el espacio de ciudad San Salvador de Jujuy.

Un tercer capítulo, como cierre de esta primera mitad de la tesis, propone una reconstrucción propia acerca de la historia y las características de la organización barrial Tupac Amaru, a partir de materiales de circulación de la organización y la elaboración etnográfica. Consideramos así su génesis como medio recompositivo de las problemáticas sociales de los '90 en la provincia, las prácticas comunitarias, las dinámicas de inclusión y exclusión sobre las que se activan, las contradicciones entre la seguridad social y la supervisión securitaria en las materialidades cotidianas, y las contrariedades en torno de los lazos comunitarios. Este capítulo pretende dar 
cuenta de su apuesta fáustica, dimensión y magnitud insoslayable del desenvolvimiento local cotidiano en los últimos años, tanto para la vida de sus militantes, como del conjunto de la población jujeña.

Una segunda parte de la tesis en su conjunto retoma cuatro momentos analíticos o experimentos críticos. Cada uno de estos apartados tiene sentido autónomo y opera en sí mismo. A partir de aquí se exploran de manera más evidente distintas perspectivas o modos de proyectar la mirada, con el fin de incorporar lecturas sobre el fenómeno sin aspiraciones de capturarlo. El proyecto expuesto a partir de este punto, ya esbozado en momentos anteriores de la tesis, pretende rastrear el modo en el que se despliegan los discursos, las sensibilidades y las imágenes a partir de una pluralidad hermenéutica. En uno de ellos, retomamos una categoría, lo visible ${ }^{13}$; en otro, aludimos a un objeto empírico, un lugar ${ }^{14}$; como tercer capítulo de este segmento, retomamos dos momentos acontecimentales históricos en condición de performance ${ }^{15}$; $\mathrm{y}$, por

${ }^{13}$ Lo visible se establece como percepción y valoración del entorno social, por lo tanto, refiere a modos de intervención material sobre el mundo (Caggiano, 2012). El campo de lo visual opera de manera sistemática y "esta organización tiene mucho que hacer con relaciones sociales, desigualdad y poder, así como con significados y comunidad compartida" (Poole, 2000: 16). Acerca del modo de ver, establecemos con Berger que "lo que sabemos o lo que creemos afecta el modo en el que vemos las cosas" (2005: 13) y que "nunca miramos una cosa; siempre miramos la relación entre las cosas y nosotros mismos" (Id.: 14).

${ }^{14}$ El lugar, desde una lectura no reaccionaria que suele vincularlo a lo patrimonial, delimitado y de identidad unívoca, puede interpretarse en relación a la especificidad que en sí converge a modo de constelación de relaciones sociales entretejidas y conectadas en un sitio particular. El lugar es comprendido como un punto de encuentro e intersección, con sentidos extrovertidos que integra de manera afirmativa lo local y lo global (Massey, 2012).

${ }^{15}$ En este sentido, no hablamos de acontecimiento -y de muchas de las implicancias teóricas que confluyen en este concepto, difíciles de resolver en lo pronto-, sino que nos quedamos con la performance como articulación estética de lo acontecimental, de un acto concreto. Tomamos a la función performativa como "una declaración y un acto cuyos efectos se despliegan en el tiempo" (Butler y Spivak, 2009: 89); "una modalidad específica del poder, entendido como discurso. (...) Lo que se constituye en el discurso (...) llega a ser la condición y la oportunidad de una acción adicional. Esto no equivale a decir que puede darse cualquier acción sobre la base de un efecto discursivo" (Butler, 2008: 267 - cursiva en la versión original). 
último, aludimos a una consigna global ${ }^{16}$. Cada uno de estos apartados requiere un recorrido y un ejercicio diferenciado.

Es así que el cuarto capítulo refiere a la visibilidad local de la organización, la manifestación, la evidencia y los componentes que suscitan la generación de significaciones que circulan como parte del sentido común local. A partir de estas modalidades de lo visible se ensaya una impronta de lectura que interpreta parte de lo que se percibe en sintonía y analógicamente con procesos de sentido históricamente experimentados en el vínculo entre Estado, ciudadanía en su conjunto y sectores populares. La aversión y la afección que generan estos lazos impregnan transversalmente la temática que se delinea a lo largo de todo el capítulo.

El quinto capítulo refiere a la obra construida como parque en el centro del cantril $^{17}$, en una exploración a partir de distintas entradas por medio de un mismo objeto empírico, en el que se activan sentidos y sensibilidades respecto de lo indígena, lo local y el capital de modo satírico y desafiante. Accedemos a este lugar, esta escena, para atravesar con perspectivas diferentes cada uno de los elementos que forman parte del entramado de su inteligibilidad.

En el sexto capítulo, en alusión a dos momentos históricos, la marcha del bicentenario de los pueblos originarios y la asunción a la presidencia de Cristina Fernández de Kirchner en 2011,

${ }^{16}$ Cuando Perlóngher (2008) habla de un manso declive, una inflexión que modula las prácticas hacia una "idea" completamente visible alerta sobre las contradicciones que acompañan al camino de la disputa en clave de derechos y consignas de la identidad en contextos de las políticas de la diferencia. Al hablar de consignas nos referimos a los instrumentos y herramientas de reconocimiento que articulan tanto las vías inclusivas o emancipatorias, como los escollos de la administración y supeditación de los cuerpos a partir de ellas (Brown, 1995).

${ }^{17}$ Expresión utilizada por la propia organización para presentar el barrio construido por sus militantes en Alto Comedero, en una alusión paródica a las urbanizaciones privadas -diseñadas para sectores socioeconómicos elevados- conocidas como countries. 
se desanudan las implicancias, los riesgos y las potencialidades de la posibilidad de "presentarse" como indígenas en demanda al Estado. Los retomamos como acontecimiento performático con la intención de acompañar dicho discurso en una interpretación transversal, un vector que esboza sus caminos, obstáculos y orientaciones.

Por último, el séptimo y último capítulo de la tesis indaga en la marcha del orgullo LGBT organizada por la Tupac Amaru en Jujuy. Tomamos al orgullo como consigna global, es decir, como campo discursivo de disputa o reclamo, para observar el modo en el que adhieren, dialogan, se la apropian y batallan. Buscamos detonar a partir de esta consigna y un despliegue público de este tipo, discusiones acerca de los cuerpos visibles, las disputas por los símbolos locales hegemónicos y las condiciones que pugnan por la materialización de la identificación mediante el orgullo y la dignidad.

La tesis cierra con conclusiones que repasan y sistematizan las principales líneas transitadas, como punto de partida para una reflexión final acerca de las conflictividades en las que se libran los distintos modos de lazo social que se hacen presentes en la investigación. 


\subsection{Antecedentes sobre organizaciones sociales y sobre la organización barrial}

Tupac Amaru

\subsubsection{Presentación. Marco global introductorio sobre movimientos sociales}

Existen múltiples y heterogéneas caracterizaciones del concepto de movimientos sociales en tanto fenómeno global e histórico de larga data. Este concepto refiere a la acción y praxis humana colectiva en razón de fines políticos, culturales y económicos.

Podemos entonces reconocer miradas macro que intentan sistematizar los movimientos sociales a nivel global. Ellas funcionan como piso teórico contemporáneo enmarcando los cambios en el capitalismo tardío: interpretaciones acerca de la colectivización de singularidades (Hardt y Negri, 2005), de la no institucionalización de la participación, la función de los movimientos como articuladores de nuevas demandas (Laclau y Mouffe, 1987; Laclau, 2011), acerca de la reconfiguración identitaria frente a nuevas consignas y respecto de los repertorios de acción colectiva (Tarrow, 1997). También se suman aquellos estudios que los historizan (Tilly, 2010), que los presentan como sistemas sociales y redes sociales (Melluci, 1999), que analizan los repertorios de acción colectiva y sus razones (Touraine, 1997), los que ahondan en ciertos matices rearticulatorios de conflictos de larga data en razón de los cambios en la posmodernidad globalizada (Castells, 2004).

Así también, dada la coyuntura regional elegida se destacan como antecedentes para nuestro trabajo algunos estudios de movimientos sociales latinoamericanos con foco en la región andina 
boliviana: desde el entramado de las organizaciones sociales que forjaron el movimiento indígena hacia el poder estatal (Albó, 2008; Zibechi, 2006; Rivera Cusicanqui, 2003, 1983; González Casanova, 1985; García Linera, 2005, 2004; Stefannoni y Do Alto, 2008) hasta la producción intelectual que acompaña y critica el proceso gubernamental (García Linera, 2012; Stefanoni, 2012; Vicepresidencia del Estado Plurinacional de Bolivia, 2010; García Linera y Stefanoni; 2009).

\subsubsection{Antecedentes a nivel nacional sobre organizaciones sociales}

Otra instancia relevante de los antecedentes refiere a lo desarrollado a nivel nacional en torno al fenómeno de las organizaciones sociales barriales, piqueteras y de desocupados en gran parte del país. En el recorrido bibliográfico acerca del tema se presentan tres procesos históricos fundamentales para la sistematización de una dinámica de los movimientos sociales en la Argentina como son las puebladas de Cutral-có y plaza Huincul, los piquetes y la protesta como método combativo masivo en Jujuy y Salta y los fenómenos de territorialización barrial que se dieron (y estudiaron) sobre todo en el conurbano bonaerense. Con esto en mente, parece importante ubicar lo que sucedió a partir de diciembre de 2001 como resultado de un proceso acumulativo que excede y antecede esa fecha. Si bien los acontecimientos de diciembre de 2001 muestran una magnitud inédita y dicho momento se comprende como una bisagra en los movimientos sociales a nivel federal, todo el repertorio de acción y lucha por la consecución de mejores condiciones de vida por medio de la colectivización territorial debe inscribirse en tradiciones previas que tienen origen en colectivos con una gesta muy anterior al nuevo milenio. 
Lo acontecido a partir de ese momento se puede leer en clave de estabilización de un repertorio para la protesta, la reproducción comunitaria y de demandas a un tipo de Estado reformulado.

La literatura acerca de la beligerancia, los movimientos sociales y la acción colectiva en la Argentina de las últimas dos décadas tiene un listado extenso y difícilmente abarcable, no sólo por la cantidad de material escrito y publicado al respecto, sino también porque implica considerar más de una década de proyectos de investigación abocados a estas temáticas, centros de estudio y análisis (tanto universitarios y desde diversas disciplinas, como políticoterritoriales), seminarios de investigación, etc.

De todas maneras, a partir de los textos más visitados podemos esbozar un bosquejo consistente con el encuadre de nuestra investigación, y que incluye las siguientes áreas de interés:

- Estudios que indagan en las transformaciones políticas iniciadas durante la década de los ‘90. Se destacan sobre todo entre esos análisis el foco puesto en el desplazamiento definitivo del Estado hacia el neoliberalismo y su incidencia en la vida de lxs trabajadorxs a nivel federal, el desdibujamiento de las certezas sociales, la crisis económica y los paliativos colectivos. También se distinguen en estos estudios las primeras observaciones sobre los nuevos modos de supervivencia y organización comunitaria y las fibras de una recomposición en las identidades colectivas basada fuertemente en lo territorial (Delamata, 2004; Fernández, 2011; Auyero, 2004; Auyero y Cafassi, 2002, Masseti, 2004). Requiere una mención aparte, por la contribución y la repercusión académica que consiguió, el trabajo en conjunto entre Svampa y Pereyra (2003) en donde se sistematiza 
tempranamente buena parte de las trayectorias de lxs trabajadorxs desopadxs, los repertorios de protesta en distintas experiencias federales y el rol de lxs jóvenes y las mujeres en dichas luchas.

- Análisis acerca del involucramiento de lxs sujetxs de sectores populares con la acción política (sobre todo peronista) en donde se asume que dicho vínculo es propiciado por vía del clientelismo (Auyero, 2001) o porque ven, en su lugar, afiliaciones identitarias territoriales de otro tipo (Merklen, 2005; Schuttenberg, 2011). La compilación de Forni y Castronuovo (2014) acerca de la organización colectiva y la figura del Estado promueve debates actualizados acerca de las modificaciones durante el kirchnerismo en la eterna disyuntiva entre interés-desinterés, militancia-contraprestación, clientelismo-consecución de bienes a partir de la acción.

- Trabajos de los que se desprende un involucramiento más directo entre acción política e investigación, sobre todo en estudios en el conurbano bonaerense (Fernández, 2011; Ferrara, 2003; MTD Solano y Colectivo Situaciones, 2002). De manera situada y detallada, actualizando categorías por medio de una labor etnográfica, Manzano (2013) trae un nuevo aporte a la bibliografía al respecto.

- Estudios genealógicos que analizan la figura de los piqueteros a contraluz de los análisis históricos del lumpenproletariado (esta vez, en clave afirmativa) (Rodríguez, 2007). O aquellos que sitúan a las formas asamblearias, comunales y de protesta de la mano de una necesaria historización de dichos repertorios en el contexto argentino (Lobato y Suriano, 2003).

- Abordajes antropológicos acerca de las configuraciones espaciales que operan en las nuevas dinámicas urbanas (re)politizándolas (Grimson, Ferraudi Curto y Segura, 2009). 
Etnografías que permiten observar de qué manera se atraviesan las politicidades con el entramado cultural y moral (Frederic, 2004) o los modos que adquiere la subjetividad colectiva en el movimiento de los desocupados (Retamozo, 2009) o los procesos de discriminación y criminalización de la colectivización de los pobres (Korol, 2009).

- Aquellos trabajos que ponen atención a la creatividad política y la regeneración social (poiesis) en este tipo de vínculos (Dri, 2008; Eroles, 2009; Nuin, 2008).

- Compilaciones de abordajes sociológicos en torno de la estructura de los movimientos sociales, los modos de ciudadanía, la identificación colectiva y el vínculo con el Estado (Kessler, Svampa y González Bombal, 2010; Villanueva y Masseti, 2007; Bráncoli, 2010).

\subsubsection{Antecedentes en Jujuy y sobre la Tupac Amaru}

Algunas de las investigaciones mencionadas anteriormente hacen foco parcial en la historia de la movilización jujeña desde fines de los ‘ 80 , por los niveles de repercusión que tuvo y por las figuras de relevancia que alcanzaron el plano nacional durante la época. El marco local, de un crónico olvido distributivo federal como parte de características históricas y razones coyunturales geográficas y económicas, derivó a que en la década de los '90 la situación socioeconómica se agravara drásticamente (Lagos y Gutiérrez, 2009) por el exponencial aumento de los trabajadores desocupados y de los sectores empobrecidos. Entre los estudios realizados en Jujuy hacemos alusión a aquellos que se enfocan en los grandes conflictos de inicios de los '90 (sobre todo el 'Libertadorazo') (Kindgard, 2009; Rodríguez Blanco, 2002). En ellos se destaca el modo en el que en este período histórico las organizaciones sindicales 
normalizaron un repertorio de lucha de características 'movimientistas' y asamblearias (Castillo, 2007) que se extendió entre distintos colectivos configurados como actores políticos relevantes, no sólo a nivel provincial, sino también a nivel nacional (Olmedo, 1998). Entre los antecedentes locales, también se identifican reconstrucciones analíticas a partir de la cobertura periodística local, tanto de los históricos piquetes en la ruta nacional 34, como de los cortes en la capital provincial (García Vargas, 2002; Kindgard y Gómez, 2000).

Asimismo, encontramos estudios específicos acerca del fenómeno que supone la organización Tupac Amaru en el contexto jujeño.

Los trabajos de Battezzati $(2014,2012)$ definen a la Tupac como sistema de intermediación de los intereses de los sectores populares frente al Estado, de carácter jerárquico informal, monopolizador de las demandas del campo popular local, y consideran las posibilidades de asociación y reclamo entre los distintos niveles de gobernabilidad.

La investigación de Moscovich (2009) también hace hincapié en el accionar de la organización respecto de los gobiernos nacional, provincial y local, los canales de derivación de los recursos y el evidente peso de la Tupac en distintas disputas por la legitimidad y la representatividad frente al gobierno local tradicional.

El trabajo de Rodríguez Blanco (2011), que aborda algunas de las cuestiones ya planteadas en los trabajos antecedentes, se aboca al estudio del movimiento en tanto articulación de redes clientelares y redes de protesta, con transferencia discrecional de recursos, en el que conviven formas asamblearias con prácticas no democráticas. Asimismo, cuestiona a la figura de Milagro Sala como encarnación de un espacio de poder no revocable, con privilegios económicos que la 
separan del resto de lxs militantes.

Tabbush y Caminotti (2015), por su parte, indagan en las dimensiones de género en la Tupac, en donde encuentran un panorama rico para considerar el empoderamiento de mujeres y su lugar protagónico en la organización, el papel de liderazgo por parte de una mujer indígena, el reconocimiento de identidades sexuales diversas y las dificultades para la incorporación de una agenda acerca de las problemáticas de las mujeres. Definen a la Tupac como organizaciónbienestar, como fuente de ingreso, protección social y de acceso cultural para sus militantes.

Finalmente, Gaona (2011), Gaona y López (2013) y Cortéz, Gaona y López (2010) plantean etnografías en clave de género que se preguntan por la cotidianidad de la vida de los integrantes de la organización, la imposibilidad de disociación de la experiencia militante, comunitaria, laboral, familiar, doméstica y social entre quienes viven en el cantri de Alto Comedero y el rol que la organización juega en la elaboración cotidiana, los tipos de familia que se conforman y el quiebre cultural que supone la incorporación de mujeres en roles de liderazgo y en oficios no previstos según patrones de socialización de género hegemónicos.

\subsubsection{Estudios con perspectiva de género}

En relación a los estudios de organizaciones sociales y movimiento piquetero desde una perspectiva de género, con los años se han ido incrementando las investigaciones pertinentes como antecedentes.

Encontramos estudios que historizan el rol desplegado por las mujeres en las primeras luchas 
piqueteras en el interior del país y su incidencia en la transformación a partir de la experiencia de politización (Andújar, 2005); en los que se pone en cuestión la participación de las mujeres y la organización de lo cotidiano, la cuádruple carga de trabajo, los roles que ocupan en el ámbito público (Causa y Ojam, 2008; López, 2011); la manera en que se constituyen demandas feministas populares cuando se articulan en el marco colectivo, en tanto cadena de equivalencias (Di Marco, 2011, 2003); las agendas de género y espacios de mujeres que posibilita la reunión, y el margen de receptividad que se les permite en territorios fuertemente masculinizados y volcados a una agenda de clase (Partenio, 2008); la consolidación de las desigualdades en la práctica por medio del encumbramiento de liderazgos masculinos y la reafirmación de los roles de cuidado femeninos (Cross y Freytes, 2007).

El cruce entre clase y género devela en todos estos trabajos una reformulación de categorías comunes a la bibliografía sobre politicidad en sectores populares. Sobre todo al tener en cuenta el carácter eminentemente androcéntrico que portan aún en la elaboración crítica muchas de las categorías políticas que utilizamos en el análisis. Estos estudios nos advierten acerca de la distancia en la experimentación ciudadana aún en un panorama progresista, las operaciones de reformulación identitaria a partir del involucramiento político, el reconocimiento de opresiones y violencias a partir de la colectivización de la experiencia personal, los avatares del peso cultural en vistas a conjugar tiempo familiar/doméstico, tiempo de trabajo remunerado y tiempo comunitario, y los alcances transformadores de estas vías comunitarias para la concienciación de género. 


\section{PRIMERA PARTE. CLAVES DE LECTURA}




\section{MARCO METODOLÓGICO}

\subsection{Presentación}

La construcción del corpus para movilizar las reflexiones y teorizaciones generadas en esta investigación fue conseguida a partir de distintas etapas de elaboración y encuadre de una serie de recursos empíricos. Este programa de recolección fue llevado adelante alternadamente durante un período de ocho años (2008-2015), mediante el cual asumimos que fue saturada la meta de componentes necesarios para dar cuenta de la amalgama de significados, imágenes y experiencias que recorren a la organización barrial Tupac Amaru en el sentido que pretendemos analizar en esta tesis.

En tanto se hizo un seguimiento exhaustivo de la trayectoria organizacional y movimientista, de los constantes devenires y modificaciones a lo largo de los años, se intentará mediante diversas vías dar cuenta de dichos procesos. Este trabajo pretende la indagación sobre elementos de orden popular que operan como espejos conceptuales reforzando todo un andamiaje de legitimación de modos identitarios que, asumimos, son el sostén de discursos contemporáneos locales que constriñen, en doble línea, tanto a los debates como a los procesos políticos y de transformación.

Frente a este tipo de discursos distinguimos escenas estético/políticas que pretenden 
abarcar materiales [que carecen] de una formalización acabada y explorar los pliegues de sensibilidad de una trama cultural hecha no sólo de discursos constituidos, sino también de discursos flotantes, de difusas ideologías prácticas, de gestualidades semi-esbozadas, de simbolizaciones incompletas. (Richard, 2001: 139).

Asimismo, apelamos a la definición de escena que propone Silvia Delfino, y retoma Leavi (2013), en tanto ámbito "donde se tensan lenguajes, prácticas y culturas, a partir de modos diversos de intervención (...) cultural y política” (2013: 4).

Los materiales que retomamos para la construcción de estas escenas tienen origen empírico. Una explicitación acerca de las herramientas metodológicas aplicadas y los criterios de configuración del corpus es detallada en los apartados acerca de los modos etnográficos construidos, tanto en la fase más tradicional de dicho método, como en su reconfiguración consistente con los recursos y experiencias de significación cultural contemporáneos, la faceta multi-situada de la etnografía.

Como observación final de este apartado introductorio y antes de pasar al detalle en profundidad del diseño metodológico es importante señalar que la investigación está atravesada por el criterio epistemológico de la 'objetividad fuerte' (Harding, 1993) dado que, como afirma Alcoff, "ningún trabajo teórico es ajeno a la experiencia de quien lo ha escrito" (1999: 125). Esta posición, a distancia de subjetivizar lo planteado, revela en la reflexividad misma los propósitos de construcción de un análisis consistente. El reconocimiento de la 'situación' ${ }^{18}$ de

18 Tanto Haraway, como Harding remarcan la relevancia de reconocer las condiciones que atraviesan a la 
quien escribe hace a la vigilancia epistemológica hacia la validez del conocimiento: una crítica sobre el contexto de quien escribe, las implicancias del bagaje de formación académica, los presupuestos científicos, la naturalización sobre las valoraciones sociales y las posiciones personales como elementos constitutivos y fundantes del proceso de investigación. Esto a fin de ubicar en el mismo plano crítico al sujetx de análisis y al sujetx que investiga (Harding, 1998), y recuperar el proceso mismo como riqueza de la reflexión, en tanto visibiliza la situación (Haraway, 1991), los intereses y los deseos de quien investiga. Entonces, este movimiento pendular entre análisis comunicacional de una escena político/cultural, evaluación sobre el campo teórico de inscripción y lectura de la propia incorporación a dichos debates y al terreno empírico es transversal a la escritura de la tesis.

\subsection{Construcción del objeto de estudio}

Las preguntas iniciales de investigación que formulamos parten del seguimiento específico sobre una noción de sentido amplia que cobra magnitud en el contexto urbano jujeño como parte del sentido común local ${ }^{19}$. Esta noción a la que nos referimos contiene las arbitrariedades de lo difuso pero señalable, en tanto amalgama de experiencias y discursos acumulados, como caracterización opaca e irresuelta en relación al sentido mismo que toma en un entramado

investigadora: con un género, una procedencia geográfica, un nivel educativo, una orientación sexual, intereses políticos. Esto contribuye a evidenciar la vía por la cual se generan las problematizaciones en esta y en cualquier investigación. La problematización tiene que ver con que ello sea efectivamente un problema para alguien (Harding, 1998).

${ }^{19}$ En el sentido gramsciano del término como pensamiento genérico de carácter difuso y disperso en una cierta época y en un cierto ambiente popular (Gramsci, 2011). Como su terreno es ambiguo y se sustenta sobre una suerte de filosofía reducida incoherente es más difícil de derribar que un pensamiento coherente y articulado (Gruppi, 1978). 
cultural específico. Para decirlo de otro modo, interrogamos al sentido común en su contexto de circulación y legitimidad.

Aquello que en las categorías analíticas en otros momentos de la tesis es definido como sujetx políticx, como masa, como multitud o como abigarramiento político de singularidades, se encuentra en los insumos del campo en el abanico sustantivo que llama a 'la Tupac', 'los tupaqueros', 'Unidos y Organizados', 'las organizaciones sociales', 'los piqueteros', 'la Milagro', 'la organización de Milagro Sala', u otrora 'la CTA'. Nombres que intentan aunar en un mismo apelativo, y como parte del sentido común local, toda una serie de características recurribles acerca de disputas por los lugares, los cuerpos y las pertenencias en una lucha cultural/política.

Poner de manifiesto el carácter heterogéneo y contradictorio de los materiales no implica una falta de precisión en la definición del problema, sino que da cuenta de la opacidad inmanente de la maquinaria simbólica social como objeto (Delfino, 2012). "Si la realidad es impenetrable, existen zonas privilegiadas -pruebas, indicios- que permiten descifrarla" (Ginzburg, 1999: 162). En estos casos, la heterodoxia como práctica resulta operativa para armar desde fragmentos, mapas de relaciones que se nos presentan como situación de producción de sentido.

Bajo esta premisa es que se construye una serie de constelaciones conceptuales (Benjamin, 2005) con intención expositiva, en la búsqueda de una genuina yuxtaposición de elementos, como sistema de imágenes e ideas a modo de representación que apela a los fenómenos, sin intentar subsumirlos categorialmente. Ésta es considerada una vía plausible dado el registro empírico sobre el que sostenemos nuestro análisis. Para ello se asume la necesidad de dividir y 
deconstruir imágenes a fin de reelaborarlas en un nuevo registro.

Para presentar la multiplicidad de factores que intervienen en la búsqueda interpretativa de lo colectivo, se ordena un mapa rizomático que da cuenta de los planos en los que se procuran leer las influencias, los elementos en curso y las conceptualizaciones posibles, tal como lo plantean Deleuze y Guattari (2004). Resulta operativo utilizar el modelo rizomático debido a que permite contemplar la mayor cantidad de percepciones y elaboraciones discursivas singulares, en pos de conservar la polifonía de los registros. Así también, nos posibilita observar elementos de otro modo inasibles desde un enfoque holístico. El enfoque de investigación se ve de este modo sometido a un esfuerzo de lectura transversal sobre distintas operaciones colectivas que responden a lógicas no del todo discernibles desde una mirada general.

El sujeto de análisis de esta investigación está construido a partir de una base de nominación tan amplia como las maneras en las que se intenta coyunturalmente caracterizarlo (sentidos comunes sociales, políticos y académicos). Por ello, se recurre a una serie de técnicas que fragmentariamente dispongan las capas posibles para el análisis. Operativamente, la exploración se basa en rastrear y recuperar la circulación de signos y sentidos a partir de las distintas modalidades en las que se hace visible el fenómeno analizado.

En base a lo hasta aquí establecido sostenemos que resulta adecuado para abordar este fenómeno un descentramiento del lugar al cual recurrir empíricamente. La labor investigativa se somete a un posicionamiento por momentos pendular, por momentos nómade que aprovecha el reconocimiento de la enorme disponibilidad de instancias interdiscursivas de época. La 
adopción de la multi-situación ${ }^{20}$ (Marcus, 2001) como estrategia implica buscar desde una perspectiva móvil, una aproximación interpretativa de un 'algo' difuso y no del todo discernible. Ese ‘algo’ y el intento pragmático-metodológico es definido por Marcus (2001) y Abu-Lughod (2006) como 'seguir la cosa', 'seguir la metáfora' o 'seguir la trama'21.

\subsection{Etnografía multi-situada}

La propuesta de un análisis multi-situado en un contexto local ${ }^{22}$ es pertinente por cuanto este tipo de abordaje implica retomar como parte de las escenas analizadas tanto a actores sociales con pie 'físico' en un territorio actual ${ }^{23}$, como en ámbitos espaciales de otro tipo, heterotópicos o virtuales -desde donde operan con igual trascendencia en la disputa por la constitución de sentidos hegemónicos-. Es el caso de ámbitos como las redes sociales mediadas tecnológicamente, los medios masivos de comunicación y otro tipo de circulación de imágenes y discursos de orden variado. En todos los casos se contemplan los estatutos de valoración que se le asigna a cada elemento en base a las condiciones de producción y circulación en las que se

${ }^{20}$ Cabe una mención a las diferentes traducciones que permite una expresión como 'multi-sited', la cual puede leerse como multi-localizada, multi-situada; multi-ubicada; inclusive multi-colocada.

${ }^{21}$ Marcus (2001) distingue cada una de estas fórmulas como distintas una de la otra. Sin embargo, en la investigación se circula entre uno y otro recurso para asir de alguna manera eso que se presenta a veces como noción, como parte de la trama o imaginario y como sujetx.

22 “Gupta y Ferguson (1997a: 39) han propuesto que la 'marca distintiva de la antropología' debería ser encontrada 'no en su compromiso con 'lo local' sino en la atención a los problemas epistemológicos y políticos de la locación.” (Abu-Lughod, 2006: p. 266)

${ }^{23}$ La distinción entre actual y virtual no los coloca como extremos opuestos o identifica a uno con lo no real o inexistente respecto de un otro de plena realidad. Lo que se intenta manifestar es que lo actual y lo virtual son dimensiones de la experiencia social que difieren en el estatuto ontológico de su materialidad, siendo de todas maneras ambos reales, relevantes, atravesados por experiencias significativas e igualmente politizables (Ficoseco, 2014). 
nos presentan.

Respecto de lo señalado en el párrafo anterior, cabe aclarar que se asumen como relevantes dos aspectos inmanentes a la experiencia: por un lado, lo visual se convierte en un terreno decisivo en la ponderación perceptiva sensorial; y por otro, se generan coordenadas espaciales virtuales con materialidad de peso en la vida de las personas -aunque aún no del todo explícita o reconocible- en donde se desarrollan elementos fundamentales de la reproducción social cotidiana (Ficoseco, 2014).

La comprensión y conjugación de ambos puntos como parte de una etnografía tornan a los modos clásicos de la práctica etnográfica en un terreno de fecundidad renovada. La riqueza de sentidos que afloran al atender de modo transversal diversos tipos de soportes, vías de comunicación e intercambio, como circulación permanente de imágenes y discursos da lugar a que se redefina la asimilación misma de aquella información que se obtiene en el contexto etnográfico clásico.

La multiplicación de dispositivos de tecnificación de la mirada y el reordenamiento de las experiencias en torno a esta disposición sensorial hace de cada sujetx y cada vínculo un objeto de enfoque multi-local (Ferrer, 2005). Cada escena cobra sentido cuando se la trasvasa con las imágenes y los discursos que la preceden y envuelven.

Los métodos de recolección de materiales para el análisis requieren reconocer las condiciones actuales de producción de sentido frente a un modelo contemporáneo cognitivo que predispone a un tipo de apropiación visualmente mediada como parte de la experiencia. Y en ese sentido, el dispositivo de mediación es un fragmento más de esta nueva forma de subjetividad. 
Me interesa proponer a las redes mediáticas e informáticas como orientadoras de la visión y como voluntades de poder que pretenden instaurar una matriz total al interior de la cual un modo de pensar y de vivir queda enmarcado y desde el cual el mundo se expone ante nosotros. (Ferrer, 2005: 7)

Para alcanzar esta reconstrucción analítica de las espacialidades múltiples en las cuales se entabla la búsqueda se hace conveniente diseñar un "mapa de los efectos de superficie" o “cartografía deseante" (Perlóngher, 2008), a modo de registro del movimiento y de cómo la multiplicidad de voces e imágenes sincrónicas requieren de un desenvolvimiento rizomático sobre dichos espacios.

\subsubsection{Registro múltiple en soportes mediáticos}

Durante el trabajo de campo realizado se asistió a la popularización y extensión en el uso de nuevos soportes discursivos: nuevos modos de ver generaron modificaciones sobre el objeto mismo al reconfigurar la producción de sentido en torno de éste a partir de otras formas de circulación y visibilidad a nivel local y nacional. Esto implicó la revisión y adecuación de las modalidades de recolección de datos a la luz de nuevos territorios y dispositivos.

El tránsito de los soportes por los que circularon y circulan imágenes y sentidos acerca de la Tupac hace de cada uno de esos espacios de búsqueda un ámbito posible para la reconstrucción histórica de la organización. En los primeros años, como punto de partida de lo analizado en esta tesis, el principal medio de circulación y comunicación del que se disponía eran los vídeos 
grabados en CDs; los discos musicales en los que grababan sus canciones coreadas por militantes; y algunas revistas de periodos de distribución reducidos. En el caso de las revistas se destacan 'Tupaquero, hoy', ‘Aukan’ y ‘Pachakuti'. En los vídeos institucionales se encuentran documentados actos, discursos, marchas y manifestaciones, imágenes de las obras en construcción y los avances generales categorizados y rotulados a partir de las áreas de Educación, Salud, Trabajo y Vivienda. En cuanto a las revistas, los contenidos se distribuyen principalmente en torno a tres ejes: entrevistas a militantes, galerías fotográficas de las obras realizadas en la provincia y actividades institucionales con autoridades y referentes de la política tradicional.

A esto se suman los folletos extendidos también de producción institucional centrados principalmente en la enumeración sucinta de los avances a nivel provincial en cada una de las localidades en las que la Tupac está presente, articuladas en las cuatro áreas ya mencionadas: Educación, Salud, Trabajo y Vivienda. Este tipo de medio de difusión opera hasta la actualidad.

El material descripto hasta aquí se encontraba disponible hasta 2008 en la sede central de la organización, por lo que su accesibilidad dependía de la visita al edificio por parte del/la interesadx. A partir de ese año, con la ampliación de dispositivos y espacios de circulación multimedia, el discurso institucional o de allegadxs y militantes se modificó y amplió a gran escala.

Por otro lado, a modo de propaganda, con los años han ido incorporando presencia mediática masiva en el ámbito jujeño mediante la publicación de suplementos exclusivos dedicados a fechas relevantes para la organización (día del trabajador, algunos aniversarios de la creación de 
la Tupac), anuarios anexados a los dos diarios locales con distribución masiva (Pregón y El Tribuno) y la cobertura televisiva año a año por parte de los dos canales de cable capitalinos (Canal 4 y Canal 2) de las celebraciones de Reyes Magos y del Día del niño.

La mayor parte de los circuitos transitados para la recolección y producción de materiales para nuestro análisis se da en medios periodísticos digitales de Jujuy y todo el país, la agencia de noticias Indymedia ${ }^{24} \mathrm{y}$ algunos blogs como disparadores de opiniones e historias.

Contemplamos también algunas producciones audiovisuales y literarias que no pueden considerarse material estrictamente producido por la organización, pero contaron con el aval institucional. Se trata, por un lado, de una serie de documentales, cortometrajes y películas de relativo alcance ${ }^{25} \mathrm{y}$, por otro, del libro 'Jallalla' (Russo, 2010). Entre los productos audiovisuales pueden destacarse 'Construyendo un Milagro' (Busaniche, 2005), 'Milagro en Jujuy' (Pereira, 2008) y ‘Algo está cambiando’ (Buj y Palumbo, 2012).

La Tupac cuenta con un área de prensa y comunicación. Desde 2008 la principal vía de difusión que utiliza esta área es la página web www.tupacamaru.org.ar en donde se publica buena parte de la información disponible, tanto la retomada de otros medios, como la generada por la organización. Esta sección de la organización realiza un seguimiento intensivo de las tareas llevadas adelante por los distintos sectores, áreas y localidades vinculadas con la organización.

${ }^{24}$ El dominio http://argentina.indymedia.org/ fue utilizado en la búsqueda de información sobre todo en la primera parte de la investigación, cuando la Tupac aún pertenecía a la Central de Trabajadores de Argentina.

${ }^{25}$ Mientras que la primera de las películas mencionadas fue distribuida más bien 'de mano en mano', los documentales de Pereira y de Buj y Palumbo circularon en cines argentinos y canales como Encuentro y Telesur. 
Así también, con la aprobación de la Ley de Servicios de Comunicación Audiovisual ${ }^{26}$ se impulsó una radio comunitaria, la FM 107.9 Pachamama, que funciona en la sede central y que cuenta con programación propia de emisión diaria. A fin de realizar un sondeo de los contenidos de la programación en esta radio, durante el trabajo de campo se llevaron a cabo períodos de escucha y registro. En primera instancia estos períodos coincidieron con momentos clave de la organización en la agenda mediática provincial y nacional, lo cual se complementó más adelante con la consideración de períodos de menor protagonismo, a fin de realizar un contraste entre distintos momentos de visibilidad.

En la aplicación de las técnicas de recolección de materiales se priorizaron tres ámbitos que consideramos importantes debido a la circulación de datos e interacciones virtuales que ahí se presentan: las redes sociales masivas Twitter y Facebook, videos de Youtube y los comentarios en las noticias de portales virtuales.

En las redes sociales mencionadas se analizaron perfiles de usuarios vinculados directamente a la Tupac Amaru y al Frente Unidos y Organizados, como la página y el usuario Milagro Sala. Así también, se rastrearon discursos en torno de la organización en perfiles públicos, grupos abiertos y páginas de Facebook a partir de una búsqueda por coincidencias basada en las sugerencias nativas del sistema. En Twitter, el rastreo de datos se concretó mediante la aplicación Twitdeck ${ }^{27}$ con el uso de diferentes palabras clave ${ }^{28}$, sondeando contenidos desde

${ }^{26}$ Ley 26.522. De servicios de comunicación audiovisual. Sancionada por el Senado y Cámara de Diputados de la Nación Argentina el 10 de octubre de 2009 y promulgada el mismo día.

${ }^{27}$ Aplicación que permite al usuarix generar una serie de columnas de monitoreo que se pueden conjugar entre grupos de usuarios, palabras clave, actualizaciones de perfil, menciones y búsquedas de diverso tipo.

${ }^{28}$ Además de la exploración mediante \#TupacAmaru (y Tupac Amaru), \#tupaquero, \#tupaquera, \#tupaqueros, \#FUyO (y Frente Unidos y Organizados), \#Jujuy y Milagro Sala, fue necesario agregar a los sistemas de 
2013.

También se realizó una selección de videos en Youtube. Ésta consistió en reconocer decenas de materiales audiovisuales vinculados a la organización, generados institucionalmente, por parte de los militantes y del resto de la comunidad en los que se retoman momentos de manifestación y/o conflictos en la vía pública y contenidos diversos en los que, entre otras cosas, se presentan denuncias contra el accionar de la organización. A modo de datos complementarios, se consideran los comentarios realizados por los usuarios debajo de cada uno de los videos, en tanto voces a tener en cuenta dadas las valoraciones y opiniones vertidas en estos ámbitos.

Del mismo modo, se consideran las opiniones que generan las noticias acerca de la Tupac Amaru en medios de información digital. Los foros de comentarios de las noticias periodísticas señalan fragmentos de sumo interés acerca de los sentidos circulantes en torno de la organización y de su principal referente.

Estos datos y los relatos obtenidos en entrevistas y notas de campo son recuperados en referencias explícitas a lo largo de toda la tesis.

\subsubsection{Observación participante y entrevistas}

Cuando hablamos de investigación etnográfica comprendemos el carácter presencial habitualmente asociado a esta metodología, el tipo de retórica empleada y una manera particular

búsqueda, dado el error habitual, las fórmulas Milagros Sala, Milagro Salas y Milagros Salas, que es, por ejemplo, común en las publicaciones en redes sociales de diario El Tribuno. 
de acercarse y vincularse con lo empírico: es decir, la etnografía puede considerarse como método, como enfoque y como texto (Guber, 2001).

Además de la conjugación de los tres puntos mencionados, en esta investigación se contempla la instancia reflexiva inherente también al método etnográfico. Esto es la atención a la relación entre ámbito de abordaje y procedimientos empleados. Cabe señalar que la investigación atiende al criterio de 'doble hermenéutica' (Giddens, 1993) de acuerdo al cual la instancia analítica se funda sobre una interpretación de las expresiones elaboradas por parte de los sujetos acerca de su comprensión y de su modo de relación con la realidad.

La actitud reflexiva sobre la práctica de la investigadora, de acuerdo a lo que sugieren Hammersley y Atkinson (1994), implica someter a crítica todo tipo de inserción social con fines analíticos dada la imposibilidad de esquivar la propia condición subjetiva/social. El ejercicio reflexivo también supone reconocer los límites de inteligibilidad que imponemos sobre cada escena, a fin de no pasar por alto los presupuestos de quien investiga ${ }^{29}$, sus márgenes comprensivos y los límites del discurso en el cual lxs sujetxs pueden elaborar reflexiones acerca de sí.

Consideramos necesaria la aclaración previa dado que proporciona información acerca del proceso de construcción del 'estar allí' etnográfico (Geertz, 1989). Este es el dispositivo de producción de conocimiento que le da validez al método, concretado en la articulación entre

29 A estos preconceptos, que también llamamos sentido común académico, se los entiende como el conjunto de figuraciones teórico-metodológicas, las primeras lecturas y aproximaciones que hacemos con ellas y de las que nos valemos para aproximarnos a las relaciones sociales. Se trata de una serie de percepciones que ocurren en el reconocimiento mismo del campo, que definen de alguna manera nuestras indagaciones y que responden de forma plena a las limitaciones de inteligibilidad que supone cualquier tipo de discurso (sea o no académico) (Gaona y Ficoseco, 2014). 
conocimiento académico, la relación directa de la investigadora con lxs sujetxs y la reflexión crítica en torno de ambas instancias. Cuando hablamos de la relación directa con lxs sujetxs no lo hacemos ubicándonos en una situación experiencial de equivalencia con ellxs, sino más bien asumiendo que el acercamiento etnográfico y la escritura están basados en una aspiración de 'hablar cerca o próxima a', en lugar de 'hablar acerca de’ (Minh Ha, 1991; Chen, 1992) 1xs sujetxs involucradxs.

Más allá de esto, se contempla la instancia de lo que etnográficamente se denomina "inmersión subjetiva" (Guber, 2005: 174). Esta noción refiere a cómo se vivencian en términos de comprensión muchas de las lógicas internas que desde una mirada externa, superficial o de corto plazo no logran distinguirse. Fue en el trabajo prolongado, en las visitas sucesivas y en el acostumbramiento a las rutinas de la organización que se elaboraron datos que enriquecieron al abordaje hermenéutico.

En lo que concierne a la aplicación del método de la entrevista no estructurada, se registraron más de un centenar de audios de conversaciones grabadas y el número total se duplica sumando las llevadas adelante off the record, tanto de manera individual como en grupos de personas, de diferentes extensiones, concertadas previamente o de forma ocasional ${ }^{30}$. Resulta oportuno aclarar que en muchas de las entrevistas grabadas se observó una tendencia de lxs entrevistadxs a inscribir los relatos institucionales y auto-biográficos en clave de corrección moral. En lugar de considerar esto un obstáculo o de cuestionar la veracidad, dudar o deslegitimar estas

${ }^{30}$ Estos diálogos se dieron sobre todo en los momentos más intensivos del trabajo de campo durante la segunda mitad de 2008 y principios de 2009; durante casi la totalidad de 2010; el verano de 2012; alguna semana del otoño y en octubre de 2013, durante el período de campaña electoral; a fines de 2014; y en marzo de 2015. 
opiniones, decidimos llevarlo a la reflexión que se desarrollará más adelante acerca de las implicancias que supone el refugio en el discurso política e institucionalmente correcto.

A estos diálogos se suman algunas impresiones obtenidas de modo directo mediante observación en el terreno. Es así como se registran y comprenden apariencias, gestos, sonrisas y expresiones de cansancio; es decir, el lenguaje corporal como relieve observable de la experiencia. En el mismo sentido, también se recuperan significaciones territoriales cuya comprensión se alcanza en el transcurso cotidiano: los tipos de fachada en algunas casas (liminalidades de la privacidad), quiénes circulan en autos de un tipo o en motos por el barrio según la hora del día, qué significa llevar un morral en las obras, el orden en el que se encolumna la marcha colectiva, la organización de los horarios y los lugares a lo largo del día. Todos estos elementos que de una u otra manera quedan en el anecdotario de las observaciones, hacen parte de los intentos por llegar a conocer y dar cuenta de la experiencia de lxs sujetxs.

Participamos (observamos) varias semanas de obras de construcción de viviendas; asistimos al trabajo en las fábricas, las herrerías, los recreos de las escuelas y los jardines, las salitas de cuidado de primera infancia, el centro cultural; fuimos a las piletas, a los quinchos, a las casas de muchxs de lxs entrevistadxs; concurrimos a festejos, manifestaciones, acampes, cortes de puentes; transitamos los pasillos de la sede central y dialogamos con quienes esperaban ser atendidxs por lxs médicxs, y con lxs profesionales que llevaban currícula para ser incorporadxs a la organización; dialogamos con algún grupo de jóvenes interesadxs en hacer una 'copa de leche' en la vera del Río Grande de la villa Punta Diamante con la ilusión de que la Tupac haga una pileta ahí; esperamos impregnadxs de la impaciencia de lxs presentes la llegada de Milagro 
a alguna asamblea de delegadxs; fuimos a la cancha con la Banda de la flaca ${ }^{31}$; seguimos a lxs candidatxs del Frente Unidos y $\operatorname{Organizados}^{32}$ (FUyO) en algunas de las ciudades del interior de la provincia y en el acto de cierre de campaña de la primera elección a la que se postularon. Caminamos hasta el cansancio para identificar los cambios y el crecimiento en el cantri, nos persiguieron los perros y en varias ocasiones nos advirtieron y señalaron los serenos como lxs extrañxs en el barrio ${ }^{33}$.

A continuación, como última instancia de reflexión metodológica se organizan períodos analíticos en la historia de la organización.

\subsection{Periodización histórica}

La periodización es parte del ejercicio de vinculación de lo teórico y lo empírico. Por medio

${ }^{31}$ La banda de la flaca es el nombre que adquiere la barrabrava identificada con la Tupac Amaru. 'La flaca' es uno de los apodos que recibe la líder de la organización, Milagro Sala.

${ }^{32}$ El Frente Unidos y Organizados es un frente político que aúna a una serie de partidos políticos, corrientes y movimientos sociales lanzado a partir del histórico acto del 27 de abril de 2012 en el estadio José Amalfitani (Vélez Sarsfield) que reunió a más de 150 mil militantes. Bajo este frente popular se congregan las agrupaciones militantes vinculadas al progresismo, el peronismo de base y el kirchnerismo. El nombre repone la consigna de convocatoria y un fragmento del discurso pronunciado por Cristina Kirchner: "Son ustedes, las nuevas generaciones, los que tienen que seguir escribiendo su propia historia. Y deben hacerlo bajo el lema de este acto: Unidos y Organizados para profundizar la transformación histórica”; y a la vez, vira simbólicamente un fragmento de un discurso de Juan Domingo Perón en 1953: "Pienso yo que el año 2000 nos va a sorprender o unidos o dominados".

${ }^{33}$ Muchos de los tránsitos más difíciles de la investigación transcurrieron durante las estadías de seguimiento observacional y de entrevistas debido a la crudeza de algunos relatos (y la naturalidad con la que se contaban), por el inevitable involucramiento empático con algunxs de ellxs, por algunas voluntades exiguas en la colaboración o por el mayor grado de mezquindad de quienes están en ejercicio de poder por sobre otrxs militantes. Las pasiones, entre el enamoramiento, el desencanto y desilusión, y la incertidumbre por la posibilidad de continuidad en muchos momentos requirieron ensayar cierto dominio estoico para aprender e incorporar sentidos revelados a partir de la propia experiencia de tránsito 'cerca de' la Tupac. 
de la periodicidad construimos la progresión del objeto en etapas o estadios mediante un cruce entre aquellos hitos que consideramos relevantes para la historización del movimiento analizado, la identificación de los cambios procesuales que se van dando, y la selección y aplicación de métodos de seguimiento diversos para considerar dichos períodos. Aunar cada uno de estos momentos como parte de un seguimiento que derive en la generación de un análisis teórico implica reconocer el marco histórico de cada momento, los recursos disponibles para la acumulación empírica y el trazado teórico que va requiriendo cada uno de los procesos analizados.

Más que como recurso didáctico-metodológico de organización, obedece a la constatación de que durante cada uno de los momentos señalados existen derivas y corrimientos, modificación de percepciones culturales y de intereses frente a la problematización del objeto que requieren dar cuenta de un trayecto institucional y político-histórico que se modifica tanto a ojos de la comunidad en la que se desarrolla como de la investigadora que lo analiza. La definición de la situación (Harding, 1993) desarrollada previamente también responde a este tipo de reconocimientos.

A continuación se presenta una síntesis de lapsos que no pretende dar cuenta de todas las modificaciones en el trayecto del movimiento sino que sirve como un nuevo zócalo de historización local que toma en la Tupac Amaru la ruta para ahondar de manera sustancial en las configuraciones culturales y formaciones políticas dominantes.

Esta periodización se asienta como parte de las estrategias metodológicas procurando definir un modo de lectura del fenómeno analizado que reconozca las variabilidades de su curso 
histórico. El eje problemático es formulado por el cruce crecimiento multitudinarioconflictividad visible. Esto se presenta, además de como un anticipo de lo que será el desarrollo histórico en profundidad de la gesta de la organización analizada, como una primera aproximación que tiene presente las diferentes fuentes conflictivas que confluyen en la organización en tanto condensadora de sentidos locales.

\subsubsection{Períodos y procesos}

Podemos reconocer una primera etapa a la que caracterizaremos como "período embrionario".

Éste se ubica a partir de 1999 con el mito fundacional del puñado de personas que comenzaron con la primera copa de leche. Muchos de los referentes actuales se auto-legitiman reconociéndose presentes cuando "no eran más que diez o quince" quienes participaban de los primeros pasos de la labor territorial.

Entre este período y los primeros años del 2000, con la relativa estabilidad institucional provincial -solo basándonos en la permanencia durante la totalidad del mandato del gobernador Eduardo Fellner-, la Tupac se convierte poco a poco en interlocutor destacado entre las organizaciones de desocupados de la provincia, en gran medida debido al eclipsamiento del rol que había ocupado la Corriente Clasista y Combativa (CCC) hasta ese momento como conductora de las protestas locales.

Un segundo período reconocible se puede establecer a partir de fines de 2003 cuando se le asigna a la organización la primera partida presupuestaria por parte del gobierno nacional para 
la construcción de viviendas en el marco del Programa de Emergencia Habitacional. La asignación más formal de recursos por parte del Estado nacional y la organicidad que implicó la constitución de cooperativas de construcción le dan un aplomo que comienza a consolidar a la Tupac como una de las dos organizaciones de mayor porte en la provincia.

Este "período de crecimiento exponencial" es clave, sobre todo a partir de la escalada de la obra construida por la organización, ya no solo a nivel local capitalino, sino a nivel provincial. El período que se extiende a partir de 2003 implica el inicio de la etapa de crecimiento más pronunciado de la organización, el cual, en un arco que comprende los quince años de la Tupac, marca un ascenso exponencial en el número de militantes y afiliados ${ }^{34}$. Es también la etapa en la que las manifestaciones sociales derivan en apuestas masivas de relevancia en el ámbito central de la ciudad de San Salvador de Jujuy, en la retícula céntrica patrimonializada, en edificios públicos y en los puentes, arterias de comunicación de la ciudad en su conjunto. Toda esta progresión (de masividad, acrecentamiento de la administración de recursos del Estado, de injerencia destacada en la cuestión sindical, de avance edilicio y de presencia pública en general) hace destacar al movimiento como figura de trascendencia incomparable en la provincia hasta 2008, cuando podríamos advertir un nuevo momento de la organización.

Como parte de la caracterización del tercer período, cabe destacar la relevancia política que adquiere también a nivel nacional e internacional en el plano de reunión y organización sindical, comunitaria y territorial, cuando Jujuy es sede de la Constituyente social durante octubre del

\footnotetext{
${ }^{34}$ Este crecimiento también se encuentra asentado en el vínculo articulado con otras 27 organizaciones sociales en la provincia a través de la participación y rol de liderazgo en la Red de Organizaciones Sociales de Jujuy.
} 
mismo año, mostrando su capacidad organizativa y de despliegue al hacer de anfitriona de la masiva convocatoria. Para este momento la Tupac ya sostiene el peso de interlocutor local de suma importancia frente a la política tradicional, voz mayúscula entre las organizaciones sociales de la región, inclinador de la balanza de la Central de Trabajadores Argentinos a nivel federal (aportando más de 70 mil afiliados a la CTA) ${ }^{35}$, intermediador fundamental de los recursos disponibles por medio de distintos programas de política pública nacional y actor de roce internacional con movimientos políticos afines en toda Latinoamérica.

Pero el inicio del siguiente período implica un acontecimiento de otro tipo, resultado de un proceso intrínseco a la constitución identitaria y posicional de la organización en su conjunto y que supone una situación de discusión permanente hasta la actualidad por parte de cada unx de los integrantes de la organización entrevistadxs. Este acontecimiento es el escrache ${ }^{36}$ que recibe en el Concejo de Ciencias Económicas de la capital jujeña el senador nacional por la provincia Gerardo Morales, figura clave de la política local y del radicalismo a nivel federal y opositor acérrimo de los gobiernos kirchneristas. A raíz de este suceso, el dirigente radical acusa el involucramiento de organizaciones que 'responden’ a Milagro Sala y la denuncia penalmente por amenazas y agresiones. Esto genera la viralización de la noticia hasta el conjunto del plano nacional, haciendo de este hecho la primera escena noticiable de gran escala en torno de la líder de la organización, y del accionar del movimiento en su conjunto. Además de la denuncia penal,

${ }^{35}$ Esta tendencia se sostiene hasta septiembre de 2010, cuando la Tupac decide abandonar su afiliación a la Central, luego de un conflicto de apoyos en las elecciones internas llevadas adelante entre los candidatos Hugo Yasky y Pablo Micheli.

36 "Morales denunció a la dirigente kirchnerista Milagro Sala por el escrache". Disponible en http://www.perfil.com/politica/Morales-denuncio-a-la-dirigente-kirchnerista-Milagro-Sala-por-elescrache-20091019-0015.html visto por última vez el 9/4/15. 
se vincula por medio de declaraciones mediáticas televisivas, radiales y gráficas - de distintos personajes del ámbito político nacional- a la organización con la malversación de fondos, la tenencia y uso de armas de fuego por parte de lxs militantes, además de una "colombianización" de la política a causa de las organizaciones sociales kirchneristas ${ }^{37}$. En la conjugación de fenómenos que acontecen en torno de la Tupac podemos considerar a este corte histórico como “período de obturación de demandas, intereses y visibilidad de los sectores populares".

El último período supone tres frentes basados en acontecimientos de gran magnitud para la organización y de un peso de repercusión sumamente relevante en las percepciones dominantes en la población jujeña y nacional acerca de la Tupac. Los reunimos en tanto acontecen a partir de 2011, pero se sostienen como parte de las características que confluyen en los procesos más actuales de la organización. A este período lo caracterizaremos como "período de desgaste y recomposición”.

El primero de ellos tiene que ver con la situación de la toma de tierras del ingenio Ledesma por parte de habitantes del pueblo de Libertador General San Martín durante julio de 2011. La violenta represión policial en el intento de desalojo acarreó la muerte de cuatro personas y más de 60 heridos. El paradigmático pueblo, símbolo de la lucha piquetera y de desocupados durante los ‘90, fue escenario del punto de partida de un período estrepitoso a nivel provincial en el que las tomas se replicaron en distintas ciudades. El involucramiento de distintas organizaciones

37 Tanto Morales como Elisa Carrió encabezan por esas semanas una seguidilla mediática iniciada en el programa 'A dos voces' de la señal de cable TN, en la que denuncian dicha escalada de los vínculos políticos con el delito en manos de las organizaciones sociales kirchneristas, que puntualizan como 'colombianización'. "Carrió: 'Algo prepara Kirchner para diciembre" Disponible en http://www.perfil.com/politica/Carrio-Algo-prepara-Kirchner-para-diciembre-20091021-0045.html visto por última vez el 9/4/15. 
sociales, entre ellas la Tupac, no sólo en la organización de la acción colectiva para secundar las tomas, sino también en las posteriores negociaciones con el gobierno provincial y el sector empresarial, es el puntapié que reconocen en la conducción de la organización como definitorio a la hora de resolver involucrarse en la política tradicional partidaria ${ }^{38}$.

Así, a este nuevo período de cesión de terrenos y construcción acelerada de vivienda también se le suma, como otro de los hechos de referencia, el planeamiento de la conformación partidaria de la Tupac Amaru en lo que será ya para la campaña de las elecciones legislativas de 2013 el Partido por la Soberanía Popular alineado dentro del Frente Unidos y Organizados por la Soberanía Popular (FUyO). En un récord histórico de afiliaciones en la provincia, el partido se presentó ante la Justicia Federal Electoral, llevando en un camión las fichas de más de 73 mil afiliadxs en un par de semanas ${ }^{39}$.

La creación de la figura del partido, más la asunción de tres diputadxs provinciales y una serie de concejales en distintas localidades de la provincia durante el mismo año, trae aparejado un complejo proceso de redefinición por el cual se desdibujan institucionalmente las acciones que corresponden a la organización barrial y las que conciernen al partido político.

Entre ambos momentos ocurre un último evento a señalar, hecho que perdura hasta la actualidad en el imaginario nacional acerca del accionar de la Tupac Amaru y de Milagro Sala.

${ }^{38}$ Dichas afirmaciones surgen en las entrevistas realizadas a Milagro Sala, Germán Noro y Raúl Noro durante el período eleccionario legislativo en 2013. Más allá de lo relatado en entrevistas, es evidente el peso de la convocatoria previamente expuesta hacia Unidos y Organizados para la participación en estos ámbitos formales a partir del año 2012.

39 “Unidos y afiliados: el Partido Político 'Soberanía popular' presentó 73 mil adhesiones ante la justicia federal" (disponible en: http://www.lavozdejujuy.com.ar/component/content/article/24538-unidos-yafiliados-el-partido-politico-qsoberania-popularq-presento-73-mil-adhesiones-ante-la-justicia-federal visto por última vez el 19/5/15). 
En agosto de 2012, la visita del equipo del programa 'Periodismo para todos' de Jorge Lanata al barrio de la organización en Alto Comedero y el conflicto generado entre lxs productores de ese programa y algunxs de los encargados generales del barrio generó repercusiones a nivel nacional. Frente a este episodio reflotaron fuertemente discursos acerca del accionar violento de lxs militantes y de la organización y se generaron nuevamente debates acerca de los recursos económicos, la productividad material, las lógicas de afiliación de lxs militantes y los procedimientos colectivos en el ámbito jujeño. 


\section{ESPACIO SOCIAL Y ESPACIOS DE CIUDAD}

\section{1. Cohabitar. Espacios y ciudades}

En el presente apartado adoptamos como punto de partida la necesaria dimensión espacial en la teoría social. Hablamos aquí del carácter sociocultural que opera en la producción de los espacios, es decir, del cruce entre espacio y sociedad que deviene en lo que llamaremos espacio social $^{40}$.

A partir de los planteos de Massey $(2004,1994)$ presentamos un argumento clave para la investigación que tiene que ver con el modo de concebirlo. Ello es que el espacio es producto de relaciones, constituido a través de interacciones, desde lo global a lo más íntimo y próximo; es la esfera que hace posible la existencia de la multiplicidad traducida contemporáneamente como pluralidad, y la esfera en la que coexisten distintas trayectorias, es decir, que existe la heterogeneidad; está siempre en construcción a partir de las relaciones; y es siempre político.

La condición de heterogeneidad del espacio no debe pasar desapercibida, dado que esto implica tener presente lo radical de la cohabitabilidad de la alteridad y la diferencia, como parte intrínseca de la constitución de cada espacio social.

Cualquiera sea su entidad simbólica, el espacio responde de igual manera a las lógicas y

${ }^{40}$ Si bien autores como Soja (2010) hablan de espacialidad para referir a este cruce, haciendo la distinción de aquello que reconoce como espacio, optaremos por la noción de espacio social, más cercana a los planteos de Lefebvre (1974) y Massey. 
características aquí planteadas: es siempre producido, reconocido y reproducido; legitimado, disputado y resistido; con capacidad de incorporar elementos diferentes, intentar clasificarlos y ubicarlos e intentar dirimir roles para cada unx 'presente'.

El planteo hasta aquí expuesto es de raíz materialista e intenta superar la dualidad espaciotiempo como forma de análisis, o la preeminencia de uno por sobre otro. Se entiende que así como el tiempo es el posibilitador de la progresión y la transformación, el espacio cumple un rol igualmente fundamental en tanto posibilitador de la multiplicidad de elementos (Román Velásquez y García Vargas, 2008; Harvey, 2007).

Esta posición se presenta como no esencialista acerca de lo que corresponde a la espacialidad como vía de análisis. Entendemos que los espacios no se limitan a meros escenarios a priori neutrales, vías para comprender o superficies dentro de las que se contienen las relaciones sociales, sino que son en sí mismos un hecho social, una producción (Lefebvre, 1991) o un producto en constante proceso; los espacios son forma y dimensión de lo social (Román Velásquez y García Vargas, 2008), "parte integral de la producción de la sociedad" (Massey, 2005: 123). Es decir, que cada lugar que construimos analíticamente y que construyen lxs sujetxs involucradxs en el territorio de análisis no son vistos como escenarios en donde transcurre lo acontecido sino, en cambio, configuración producida por dichos acontecimientos y dichos vínculos y condicionante de lo que allí pasa. No se trata en este caso de posicionar la mirada en lo espacial, ni de hacer un remarcado énfasis en su carácter de producido, sino más bien en entender el modo en el que la sociedad al experimentar el vínculo produce geografías.

El espacio (social) no es una cosa entre las cosas, un producto cualquiera entre los productos: más bien envuelve a las cosas producidas y comprende sus relaciones en 
su coexistencia y simultaneidad: en su orden y/o desorden (relativos). (Lefebvre, 1991: 129)

Atender a los sentidos, configuraciones y disputas que se articulan en torno a la construcción de esos espacios implica aproximarnos al modo en que un orden de relaciones sociales es cristalizado y visibilizado como normativo, mientras que otras posibles configuraciones son clausuradas al producirlas ubicadas como marginales o impropias en un marco de inteligibilidad que solo permite entenderlas de esa manera.

Esta materialización de lo espacial se construye a partir de las significaciones que hacen lxs actorxs y lo atraviesa afectándolxs tanto en sus modos de acción, como de apropiación. El espacio social depende de que sus participantes interpreten y signifiquen qué pasa a su alrededor. Por tanto, es percibido, valorado, caracterizado, conceptualizado y representado a partir de la experiencia vivida.

El abordaje problemático de los espacios devela distintas instancias por las cuales las prácticas, y los sentidos producidos en ellas van estructurando y materializando napas significantes que intervienen de manera fundamental en la intersección de relaciones que se reconocen como espacio.

Lxs sujetxs no sólo construyen actuando los espacios, sino que se construyen a sí mismos al actuarlos. Es decir, que en el juego de significar y reproducirlos, se posicionan y legitiman como actores -no del todo libres, no del todo determinadxs (García Vargas, 2010a).

Las trayectorias previas, la fórmula de percepción espacial previa con la que se incorporan a nuevos lugares, también implican complementar discursos hegemónicos y tradicionales de los 
nuevos espacios experimentados a partir de esos términos de lectura. Los sentidos comunes acerca de las formas y dimensiones de los espacios condicionan de manera específica el modo en que se los experimenta. Sin embargo, la conflictividad y complejidad siempre presentes en las experiencias redefinirán a su vez el desarmado y rearmado de sus propias definiciones espaciales y territoriales.

De los espacios sociales contemplamos necesaria también la definición de los espacios de ciudad. Dice Park que la ciudad es la más consistente y más lograda tentativa de las personas por hacer del mundo en donde viven un lugar de acuerdo con sus deseos. Indirectamente, y sin ninguna idea clara de la naturaleza de su tarea, al hacer la ciudad, las personas se rehacen a sí mismxs (Park, 1967, cit. en Harvey, 2013).

La producción del espacio de ciudad no se da de manera lineal, ni de una vez para siempre; sino que la ciudad se entreteje en una constante disputa condicionada por las relaciones de poder, de producción y de consumo, y de visibilización de lxs actorxs atravesadas por los sentidos atribuidos a cada lugar.

Los sentidos de ciudad son "social e históricamente construidos" (García Vargas, 2010a: 18) de manera simultánea en varias escalas y están vinculados con un conjunto de relaciones de poder específicas. Estos sentidos se configuran a partir de la experiencia más cotidiana de proximidad, como a partir de sentidos más arraigados en la memoria colectiva y los imaginarios sociales que circulan y se sostienen sobre todo a través de mediatización de los discursos (Burgos y García Vargas, 2008), las representaciones cartográficas (García Vargas, 2003) y los 
rituales (Gaona, 2014c) ${ }^{41}$.

La ciudad porta en sus formas las claves de los sentidos hegemónicos que la constituyen. La legitimación de lxs actorxs que producen las interpretaciones de ciudad ${ }^{42}$, los sentidos que delimitan posibilidades de acción, participación y apropiación entre los actores, y la espacialización que portan todas las experiencias humanas condicionan los usos y sentidos de ciudad en una jerarquización fragmentada que territorializa las relaciones dentro de ella. "Es así que el sentido de ciudad dominante se parece al sentido común y, como él, configura un horizonte de expectativas que es restringido" (García Vargas, 2010a: 22).

Es también restringido el acceso a condiciones de mejor calidad de vida reguladas en el cruce Estado-mercado: el acceso al transporte público, a bienes culturales gratuitos, a requisitos mínimos de habitabilidad proporcionados por el Estado (cloacas, electricidad, agua potable, gas, y la anhelada noción de la vivienda). Esta serie de elementos que se reportan fundamentales para la vida en la urbanidad, se ven la mayor parte de las veces velados frente a una agenda acerca de lo que se asume como clave en la habitabilidad urbana: la fluidez del tránsito, la noción actual de 'seguridad', las estéticas mercantilizadas, etc. Este tipo de experiencia de la ciudad responde a una ciudadanía patrimonialista y de consumo (Svampa, 2005) que predomina actualmente en las lógicas de comprensión urbana.

${ }^{41}$ Las referencias bibliográficas señaladas en este párrafo corresponden específicamente a estudios realizados en San Salvador de Jujuy y hacen al mapa de interpretación de los procesos hegemónicos de constitución de la ciudad.

42 "Se parte del reconocimiento de que en la sociedad hay una lucha por la hegemonía, que pasa por la disputa entre campos (...), 'dueños' y administradores de un capital social objetivado en discursos, instituciones y prácticas que tiene como finalidad el impulso y la legitimación de ciertas concepciones del mundo". (Reguillo, 2007: 4) 
Las distancias, la segregación y las fronteras (aún las más próximas) no son partes fortuitas en el armado de una ciudad, sino que son parte del proyecto de constitución de las desigualdades sociales en lenguaje espacial. "El límite no es un hecho espacial con efectos sociológicos, sino un hecho sociológico con una forma espacial" (Simmel, 1986, cit. en Segura, 2009: 43). El aislamiento percibido por algunos sectores de la sociedad, o la efectiva materialización de la necesidad de distanciar a elementos indeseables (barreras, paredones, relocalizaciones forzadas ${ }^{43}$ ) condiciona la experiencia de ciudad de tal manera que en la ecuación los procesos de segregación se hacen simbólica, física, económica y culturalmente más y más difíciles para aquellxs relegadxs en el mapa.

El impulso de las ciudades modernas por los cuerpos móviles no es contradictorio con las trabas puestas a la circulación de todas las alteridades que no se correspondan con las expectativas y arquetipos planteados para cada espacio de ciudad. La ilusión de lo público y lo fluido se sostienen sobre todo a partir de la velada promesa de segmentación de lo heterogéneo, de la fragmentación en los ámbitos de circulación y de la negativa al contacto en la experiencia masiva que supone la ciudad. Los muros se generan en la percepción misma, mediante la clasificación inmediata sobre los cuerpos que circulan (Sennet, 1997).

Las condiciones materiales que cimientan estas barreras funcionan performativamente ${ }^{44}$,

${ }^{43}$ Para el análisis de este tipo de casos, ver Carman 2011, 2006.

44 Territorializamos nuestras experiencias y a partir de este mecanismo, por el cual intentamos darle sentido de soporte material a nuestras intersecciones relacionales, es que definimos las proxemias y lejanías, las distancias y las cercanías. El territorio, en este sentido, es "de un orden más accesible" (Segato, 2007: 71), en tanto espacio recorrido y apropiado políticamente (Ibíd.). El reconocimiento por el cual los sujetos se escenifican a sí mismos en un terreno que ya fue definido previamente por otros, hace a las interpretaciones de sus experiencias en él, inicialmente desproblematizadas, incorporándose al territorio como actores con un rol. 
ejerciendo poderes preeminentes por los cuales legitiman su propia sustancialidad. Los bordes de lo experimentado, de aquello que se ve, se practica y se siente, de alguna manera van construyendo imaginarios acerca de los límites y las tramas posibles a través de las cuales simbolizamos los espacios y simbolizamos los cuerpos. La mayor o menor porosidad accesible depende de la jerarquía por la que se organicen culturalmente factores de género, de clase, etnia, raza, nacionalidad, religión y sexualidad.

Así también, las coordenadas sociales que nos imaginamos en la ciudad, aquellas que parecen más naturales, los nortes y los sures, las diferencias topográficas que definen a uno u otro punto de la ciudad, están cargadas de percepciones que hacemos, sentimientos que nos generan, preconceptos que armamos inclusive a partir de aquello que no conocemos en la ciudad (Grimson, 2009). Así como en el Río de La Plata hablar de 'tercer cordón', el oeste, o el bajo remite a procesos clasificatorios comunes -aunque no coincidentes-, en San Salvador de Jujuy hablar de El Alto, la zona sur o la vera del río, nos construye un mapa social que logramos identificar de manera casi instantánea.

La vigencia y eficacia de estas percepciones y de otras que regulan las relaciones sociales se apoya en parte en la invisibilidad de los modos de ejercicio de poder y en la naturalización del vínculo jerárquico mediado sobre todo por el género y la clase. Pero nunca esta determinación puede hacerse de manera acabada. Poner la mirada en las construcciones espaciales hegemónicas nos habilita a pensar también -inevitablemente- no sólo en lo que queda por fuera del modelo normalizado, sino también en las disputas por la vigencia de esos sentidos, y sus resistencias, lo que marca experiencias territoriales violentas y dispares.

Como ya mencionáramos, cuando hablamos de inaccesibilidad, no lo hacemos en un sentido 
estrictamente de clase, sino en razón de la multidisposición generada también a partir de marcas que tienen que ver con otras operaciones de exclusión social fundadas en elementos de género, de sexualidad, de raza, de etnia, etc.

Por un lado, no es sólo que el capital se esfuerce por generar paisajes operativos para las dinámicas de mercado como parte de sus lógicas de sostenimiento (Harvey, 2014), sino que además hace operar a los espacios de ciudad de manera expulsiva, organizando, expandiendo o aglomerando sectores poblacionales, actividades y modos de habitar y practicar cada espacio en razón de dichas lógicas ${ }^{45}$.

Se naturaliza de tal manera que los espacios de ciudad son mosaicos fragmentadores de los vínculos -en razón del consumo, la división social del trabajo, la posibilidad en el acceso a partir de las distancias- que la producción alternativa de dichos espacios (economías comunitarias, reapropiación de lo patrimonializado, visibilización de lo velado) fuerza a evidenciar su carácter restrictivo.

Para seguir haciendo énfasis en el carácter eminentemente activo del espacio -en la doble vía: por producido y por productor- es necesario remarcar su condición de espacio generizado. En este sentido, por su inapelable disposición a partir del género termina por dicotomizarse en beneficio de ciertos grupos ${ }^{46}$. El feminismo y los abordajes con perspectiva de género han hecho notar históricamente la manera en que el género ${ }^{47}$, como una forma primaria de relaciones

45 "El espacio social se produce y reproduce en contacto con las fuerzas productivas (y las relaciones de producción)" (Lefebvre, 1974: 133).

46 "Las distinciones $A$-No $A$ invisibilizadas o dadas por hecho son peligrosas, y por su peculiar afinidad con las distinciones de género parece importante para la teoría feminista ser sistemática en reconocerlas" (Jay, 1981: 47).

47 "La universalidad de la subordinación femenina, el hecho de que existe dentro de cada tipo de acuerdo social y económico y en sociedades de diferentes grados de complejidad, me indica que estamos en contra 
significantes de poder (Scott, 1996), atraviesa los sentidos sedimentados acerca de los espacios y lugares.

La noción de ámbito público, que resulta clave a la hora de pensar la práctica política, así como las posibilidades de reconocimiento, visibilización o mera audibilidad de lxs sujetxs, es repensada y replanteada desde el feminismo, en tanto aparato construido sobre la base de "una noción ideológica masculinista" (Fraser, 1993: 32) que funciona en razón del pleno dominio de clase y de género. Asimismo, las mismas universalizaciones acerca del vínculo del género respecto de lo público y lo privado fueron también muy criticadas políticamente porque las distinciones analíticas de este tipo cargan con prescripciones occidentalizantes o 'blancas' que terminan por nublar procesos históricos por parte de colectivos no identificados con este desenvolvimiento experiencial del espacio y la producción (Mohanty y Alexander, 2004; Haraway, 1991).

La división sexual del trabajo, parcialmente modificada por la inserción laboral remunerada fuera del hogar por parte de las mujeres, no modifica de hecho las cargas culturales que sostienen modelos polarizados respecto de qué hacer con el tiempo libre de trabajo, las responsabilidades familiares, las labores comunitarias, etc. Suenan a discursos conocidos y comunes en lo contemporáneo pero la aplastante soberanía patriarcal que sigue operando, no nos permite superar, avances de por medio, hábitos y comportamientos culturales opresivos para con las mujeres. Ochy Curiel se pregunta, al hablar del proceso constituyente en Colombia, “¿cuántas mujeres tuvieron que hacer la comida, lavar y planchar los trajes formales de la mayoría de las

de algo muy profundo, muy terco, algo que no se puede arrancar simplemente reordenando algunas tareas y roles en el sistema social, o inclusive reordenando toda la estructura económica" (Ortner, 1974: 67-68). 
y los constituyentes (incluyendo los de los indígenas y sectores progresistas) para que pudieran definir los términos en los que se reformaría la constitución y se definiría la nueva nación?" (Curiel, 2011: 70).

Esto no es una crítica a lo meramente formal, a la histórica exclusión de los terrenos de las instituciones políticas/públicas, sino que además procuramos llamar la atención sobre la apabullante vigencia y el sostenimiento con la que experimentamos lugares permitidos para unxs y no para otrxs (Massey, 1994), sometimientos (Segato, 2013), y disposiciones corporales y de tránsito autorizadas mediante la socialización (Tiqqun, 2013).

El proceso por el que se sexualiza el cuerpo y se lo liga indefectiblemente a la naturaleza, a lo doméstico, a la intimidad y la reserva, como artefactos que lo delimitan, hace de la socialización en el espacio por parte de ese cuerpo una experiencia de antemano predefinida por los límites mismos de la normativa de género. Esto hace inherente a cada cuerpo roles y condiciones, posibilidades y expectativas.

En otra instancia, y de la misma manera, las marcas étnicas predefinen los términos en los que se incluye al sujetx en el territorio, remitiéndolx al imaginario de lo rural o condicionando su acceso a la urbanidad de forma domesticada, en una negociación mediante la entidad categorial que tiene como resultado la pérdida en la inclusión. El quiebre del vínculo convivencial se marca también en términos de racismo ${ }^{48}$ y violencia. El espíritu fundacional de la nación, con la

48 Un racismo que "no se ampara bajo la idea de desigualdad de razas -y su jerarquización en inferiores y superiores- sino que se propone como consecuencia de una mirada sobre el estado de cosas. Inductivo y no deductivo. (...) Y por momentos, en sus presentaciones más refinadas, como derecho a la diversidad: son otros, merecen realizar su propia cultura, afirmar sus lógicas sociales, sus fórmulas económicas. Y para el cabal cumplimiento de esos derechos nada más adecuado que el territorio que les pertenece y que se encuentra lo suficientemente lejos del que lo denuncia" (López, 2012: 15-16). 
avanzada sobre las fronteras indígenas y sus pretensiones aniquiladoras, imprime en sus ciudades los visos de blancura asumida.

De esta manera el espacio social de ciudad se define tácitamente blanco, masculino y capitalista. El carácter ideológico por el cual producimos los espacios, les damos sentidos, contiene en sí una fuerte carga que generiza, clasifica y organiza en dimensiones de lugar y territorio los vínculos permitidos o posibles. La legitimación de estos sentidos da pie a una materialización reconocida como parte del orden natural por el cual los espacios se nos presentan (al parecer, de antemano) de esta manera.

La posibilidad de imaginar los espacios por fuera de esta rutina de lectura acostumbrada encuentra sobre todo en los movimientos sociales los motores para iluminar circunstancias opresivas y otras concepciones de la ciudad. Cada manifestación, protesta, apropiación de territorio, funciona en tanto pone en crisis la naturalidad con la que se experimentan las divisiones de poder a través del espacio. La operatoria analítica en este caso se asienta sobre la posibilidad de reconocer las cargas políticas permanentes de cada espacio a partir de los conflictos que convergen en la ciudad mediante dichas manifestaciones. Usar un puente como espacio de reunión celebratoria o de protesta $^{49}$, armar una carpa en la plaza ${ }^{50}$, celebrar el ritual de agradecimiento a la pachamama en una institución estatal ${ }^{51}$, vestir a las estatuas de la casa de

49 "Ciudad sitiada: caos, temor e incertidumbre" (Pregón, versión impresa del 15/03/08); "Festival de Reyes

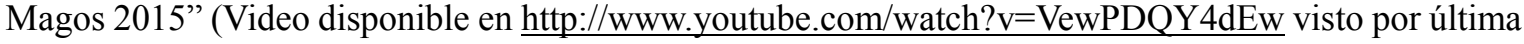
vez el 10/10/15).

50 "Tarifazo: La CTA y organizaciones sociales levantaron el acampe luego de un acuerdo con el gobierno" (La voz de Jujuy diario digital, 30/09/09, disponible en http://www.lavozdejujuy.com.ar/component/content/article/1479-ahora-tarifazo-la-cta-yorganizaciones-sociales-acampan-alrededor-de-casa-de-gobierno visto por última vez el 10/10/15).

51 "Milagro Sala juró como diputada y hubo ceremonia ancestral" (Télam, 27/11/13, disponible en http://www.telam.com.ar/notas/201311/42522-milagro-sala-juro-como-diputada-provincial-y-hubo- 
gobierno con chalecos sindicales ${ }^{52}$, son todas muestras de reapropiaciones disruptivas de lo patrimonializado. La potencia política de cada uno de estos gestos es inconmensurable por fuera de las nociones de geografías de poder, resistencia y derecho a la ciudad. Tal como plantea Harvey ¿cómo podría ser ejercitado el derecho a la ciudad para transformar la vida urbana? ¿Y qué visión de los movimientos sociales construimos para guiarnos en la lucha? Y de manera de asegurar resultados positivos en vez de caer en una violencia sin fin, un punto es claro: no podemos dejar que el miedo a la violencia nos acobarde y nos estanque en una pasividad sin sentido. Evitar el conflicto no es la respuesta (Harvey, 2013).

La propuesta de un derecho a la ciudad no es un beneficio individual, en tanto demanda esfuerzos, compromisos y solidaridades colectivas. La lectura de este tipo de luchas requiere desenfocar el horizonte hegemónico de derechos contemporáneo y considerar un carácter histórico más allá de ellos en la resistencia y la lucha de poderes.

Si bien en la actualidad los derechos parecen codificarse en términos individuales: $¿$ es el derecho a la vivienda un elemento de lo privado? ¿La salud, la educación, el trabajo han de ser vehiculizados en razón de percibir el beneficio como personal? Este tipo de preguntas, movilizadas en parte por los planteos de Brown (1995) acerca de los Derechos Humanos como régimen discursivo en el que se entablan las luchas, procura imaginarlas como piso productor de demandas que pueden devenir en vías hacia procesos emancipatorios no previstos o en un regionalismo crítico $^{53}$, como puede ser el reconocimiento de la presencia indígena en las

ceremonia-ancestral.html 27/11/13 visto por última vez el 10/10/15).

52 "Trabajadores y Gobierno procuran superar el conflicto" (El Tribuno, versión impresa del 13/03/08).

${ }^{53}$ Con regionalismos críticos nos referimos al concepto acuñado por Spivak (2012; Butler y Spivak, 2009) para considerar una localización de la resistencia y la disputa entre la especificidad local, la sinergia con 
ciudades, el respeto por la diferencia sexual, la desestigmatización de las juventudes, la necesidad de conformación de redes de cuidado infantil.

\section{2. La ciudad de San Salvador de Jujuy y su dimensión simbólica}

Para este apartado, en el que atendemos de manera más específica al espacio de ciudad San Salvador de Jujuy, asumimos al análisis de la urbanidad desde una perspectiva que pretende tener presente la coyuntura ${ }^{54}$. Esto supone atender a la materialidad de las condiciones, la sobredeterminación histórica específica y la provisoriedad de las relaciones de fuerzas, lo que promete adentrarnos analíticamente en las negociaciones y rearticulaciones permanentes entre los poderes (Grimson, 2009). La definición y localización de la coyuntura por teorizar requiere ocuparnos de rastrear el modo en el que se anudan las imágenes que dan cuenta de los movimientos contextuales.

$\mathrm{Al}$ analizar una urbanidad como la jujeña debemos entonces pensar cada imagen local como una escena en espiral, que en este caso se mueve a través de lo global, Latinoamérica y la región andina, la nación Argentina, el noroeste y la frontera, la provincia y la región de valles, entre las que además circulan una acumulación histórica frente a cada una. Así también, tener presentes las expectativas asentadas acerca de lo que respecta al futuro en los discursos circulantes. Imaginar la ciudad como un espacio local, en un contexto de cruces tan particulares como el

otras regiones y los diálogos globales, sosteniendo como abstracción el horizonte del Estado en un movimiento que pase por encima y por debajo de los nacionalismos y los etnicismos poscoloniales.

54 Cuando en la tesis se habla de coyuntura, se lo hace en el sentido en el que lo dan Hall (2010b) y Grossberg (2006). 
jujeño, requiere asumir la agencia de lo local por sobre los rumbos de lo global, lo nacional o inclusive lo regional (Massey, 2005). Con esto nos referimos a las dificultades comunes para observar coyunturas específicas en los contextos de análisis cuando los terrenos de lo analizado no son de las proximidades de lo más habitualmente visto en el ámbito académico, político o mediático. Una buena parte de los estudios sobre ciudades a nivel regional refieren a contextos en los que se tienen más presentes nociones como metrópolis ${ }^{55}$, megaciudades (Bolle, 2008), megalópolis (Freitag, 2012), o el rol de las ciudades periféricas en función de las ciudades globales (Sassen, 1999). Son comunes las alusiones a caracteres latinoamericanos, argentinos, del noroeste argentino, como si fuera posible amalgamar en una metalepsis toda una serie de procesos históricos diferenciados y marcos culturales particulares. Todas estas advertencias fueron tenidas en cuenta a la hora de construir una problematización que considere el contexto de San Salvador de Jujuy. Así también, la elección de la Tupac Amaru puntualmente como fenómeno local jujeño; si bien es una organización que incide en toda la provincia o, inclusive, en latencias nacionales, hay un interés por tener presente una coyuntura en particular, la de la capital provincial.

Existe al interior de cada ciudad una disputa entre los sentidos hegemónicos acerca de lo que representa y de lxs actorxs en ella, intentando homogeneizarla y unificarla, y existen de igual manera, una serie de heterogeneidades que la hacen una y varias ciudades a la vez. La diversidad de actores, de experiencias de ciudad, de tránsitos, accesos y condiciones de habitabilidad la hacen particular para cada unx (García Vargas, 2010a).

${ }^{55}$ Concepto, por otra parte, que sostiene con gran vigencia los planteos de Simmel (1903) y Benjamin (2005). 
Se retoma a San Salvador de Jujuy como espacio social, en el sentido que le da Massey (2005): constituido a partir de las interrelaciones, posibilitador de la multiplicidad y la pluralidad en coexistencia, en permanente construcción, por ende, nunca cerrado, y eminentemente político. Como espacio de ciudad responde a dinámicas internas en las que se expresan distintas instancias de relaciones de poder, traducidas en lugares, y se constituye en diálogo con elementos de figuración acerca del afuera, como parte del mapa que ubica imaginariamente a la ciudad con un horizonte de expectativas, valores y deseos respecto de la relación con tal exterior constitutivo.

Habiendo planteado esto, podemos introducirnos a la construcción analítica de la ciudad de San Salvador de Jujuy. Primeramente, debemos ubicarla como la capital de la provincia de Jujuy, perteneciente al departamento Manuel Belgrano, y ubicada en la región noroeste de la Argentina sobre el valle surandino ${ }^{56}$.

El crecimiento más marcado de la ciudad de San Salvador de Jujuy se da sobre todo durante la primera mitad del siglo XX. Si el Gran Buenos Aires creció más de un 200\% durante ese período, San Salvador de Jujuy lo hizo en un 579\% (García Moritán, 2010). Este marcado crecimiento no está vinculado con el fenómeno de las masas advenidas de ultramar, proceso migratorio al que habitualmente se alude a la hora de considerar los modos en los que "fue poblada" la nación. Al contrario, el corte en la mayor escalada de inmigración europea (hasta la década del 1930) coincide con el momento de mayor expansión demográfica de la ciudad

\footnotetext{
${ }^{56}$ En la provincia se reconocen cuatro grandes regiones: la Puna (Santa Catalina, Yavi, Rinconada, Cochinoca y Susques), la Quebrada (Humahuaca, Tumbaya y Tilcara), las Yungas y el Ramal (Valle Grande, Ledesma, San Pedro y Santa Bárbara), y los Valles (Manuel Belgrano -San Salvador de Jujuy, Reyes y Yala-, San Antonio, Palpalá y El Carmen).
} 
norteña, debido sobre todo a la inmigración boliviana (García Moritán, 2010; Caggiano, 2005), altamente involucrada con la producción zafrera y minera. En la actualidad, un 4,1\% de la población de la provincia es procedente de Bolivia, lo que demuestra una tasa aún alta de migración limítrofe. Este proceso, sostenido a lo largo de casi un siglo, opera articulando las identificaciones locales, ciertas adscripciones, tensiones y rechazos internos frente a la demanda por pertenencia nacional (Caggiano, 2005).

De acuerdo con el censo $2010^{57}$, se congregan en la ciudad capital 265.249 habitantes, lo que supone casi un $40 \%$ de la población provincial en una superficie que corresponde solo al 3\% del territorio provincial total. Esta primera muestra de la concentración poblacional en un sector urbano en la provincia se confirma al señalar que otro 37\% de la población está reunido en solo tres ciudades (El Carmen, Ledesma y San Pedro ${ }^{58}$ ). Si consideramos que San Salvador de Jujuy, Palpalá y El Carmen (con los pueblos de Perico y El Carmen), ciudades contiguas en el mapa provincial, reúnen a 2 de cada 3 habitantes de Jujuy podemos convalidar el argumento acerca de la aglomeración urbana en la que se concentra la población jujeña.

Este fenómeno acumulativo de la población genera una fuerte desarticulación entre los distintos sectores de la provincia, entre un drenaje histórico de las zonas altas (Karasik, 2005) y un marcado crecimiento urbano en las regiones productivas más dinámicas -basadas sobre todo en la centralización de la administración pública, y en el sector privado, a partir del tabaco y la caña-.

\footnotetext{
${ }^{57}$ Fuente: Instituto Nacional de Estadísticas y Censos. Censo Nacional de Población, Hogares y Viviendas 2010.

${ }^{58}$ Por su parte, el departamento Palpalá, colindante con el departamento Manuel Belgrano, concentra a otro $7,81 \%$ de la población provincial.
} 
Sin embargo, a las asimetrías históricas generadas a partir de la postergación económica regional y un estancamiento en el crecimiento industrial local, se le agrega el cimbronazo económico, productivo y social que significó para el conjunto de la provincia la opción del Estado Nacional hacia finales del siglo XX por las medidas hacia la instalación de un modelo neoliberal y una ideología conservadora como rumbo de los destinos federales. El experimento de la desregulación del mercado, eliminación del proteccionismo, intervención del Estado en la presión tributaria y transferencia de la renta a los sectores económicos más altos, el desfinanciamiento de la seguridad social y el desguace de las empresas públicas con posterior venta a capitales privados coordinó todos los elementos para una metamorfosis social que devino en el incremento de los índices de desigualdad iniciados hacía décadas en la provincia, fomentando altísimos niveles de desempleo, exclusión y marginalidad (Lagos y Gutiérrez, 2009). Tal como afirman Lagos y Gutiérrez, estas políticas afectaron de manera más pronunciada a las regiones periféricas, por no tener una inserción clara en el nuevo modelo.

Palpalá, cuna de la siderúrgica Altos Hornos Zapla, es un territorio paradigmático para considerar lo que supuso el traspaso de empresas públicas al sector empresarial privado, sobre todo en una provincia con bajos índices de empleo generado a partir de la industria (Jerez, e. p.). La agudización de la falta de empleo a partir de la reducción de mano de obra debido a las privatizaciones provinciales a inicios de la década de los '90, como parte del proceso que transcurría como receta económica a nivel nacional, supuso un destino laboral incierto, desconcierto en los sectores de mano de obra no técnica, y un desbarajuste generalizado entre las familias de lxs empleadxs desocupadxs. Buena parte de la población involucrada en este sector de la producción se vio obligada a recurrir al cuentapropismo, los microemprendimientos 
y a la dependencia de planes sociales (Bergesio, Golovanevsky y Marcoleri, 2009b). Este y procesos similares de supresión del empleo generaron una escalada conflictiva en los sectores urbanos de la provincia que se instalaron mediante luchas crónicas a lo largo de toda la década en forma de piquetes, marchas, huelgas, tomas y acampes.

A nivel nacional, las percepciones de inestabilidad y crisis económica se sintieron de forma más pronunciada recién después de mitad de la década de los ‘ 90 , con un estallido generalizado ya durante el gobierno de De la Rúa en diciembre de 2001. Sin embargo, en Jujuy ya a fines de la década de los ' 80 y durante todos los '90 se sufrió una situación de "ingobernabilidad” (Lagos y Gutiérrez, 2009: 102), anticipándose diez años a la crisis nacional, a causa de la falta de poder de decisión por parte del gobierno provincial, la marcada disputa a partir de intereses patrimonialistas por parte de los gobernantes, la inacción frente al desempleo y la crisis económica. Esto provocó que la provincia se ajustara políticamente al tránsito de ocho gobernadores a lo largo de la década, con una caída virulenta y conflictiva en el caso de cuatro de ellos $^{59}$ (Lagos y Gutiérrez, 2006). Todo este período estuvo en manos de gobiernos justicialistas.

La situación local se desdobló entonces en dos modos de experimentación de la ciudadanía política. Por un lado, como parte del giro conservador promulgado por las lógicas neoliberales, un gran sector de la población se volcó a una anomia despolitizada traducida en la mediatización

${ }^{59}$ Ricardo De Aparici renuncia (1987-1990); Eduardo Huáscar Alderete completa el mandato del anterior (1990-1991); Roberto Rubén Domínguez renuncia (1991-1993); José Carlos Ficoseco renuncia (19921994); Oscar Agustín Perassi completa el mandato de los dos anteriores (1994-1995); Guillermo Eugenio Snopek fallece (1995-1996); Carlos Alfonso Ferraro renuncia (1996-1998); Eduardo Alfredo Fellner completa el mandato, y es electo y reelecto (1998-2007). 
de la política tradicional ${ }^{60}$. Por otro lado, la emergencia del movimiento de desocupados y la fuerza que adquirieron parte de los gremios estatales ${ }^{61}$ se tradujeron en una potente resistencia popular frente a gobiernos débiles, un marcado uso de la fuerza oficial para combatir la protesta y un clima generalizado a lo largo de toda la década de beligerancia social e inestabilidad gubernamental.

Consideramos que estas tres instancias de la ciudadanía local -un sector de la población que se desvincula de la acción participativa política, un sector tendiente al conflicto público en razón de demandas de clase frente al Estado, y un gobierno caudillista justicialista que responde a los rumbos federales sin un fuerte peso de reconocimiento y legitimidad local- se sostienen hasta la actualidad.

Estas modificaciones en la convivencia urbana se tradujeron también en un agravamiento de las marcas de desigualdad territorial, a partir de la marcada expansión de asentamientos populares y las disputas por la cesión de terrenos y condiciones de hacinamiento en la zona sur de la ciudad. Por otra parte, se terminaron de consolidar en los sentidos de ciudad una marcada distancia entre lo que acontece entre los ríos Grande y Chico (o Xibi Xibi), y el resto de la

60 Esto se vincula también con la modificación en los consumos a partir del acceso al servicio de cable privado con transmisión casi exclusivamente de contenidos producidos en la región metropolitana nacional, y por otro lado, a la influencia y la marcada parcialidad en la producción mediática local influida por el uso discrecional de la pauta oficial a nivel local (García Vargas, Arrueta y Brunet, 2009).

${ }^{61}$ Kindgard (2009) reconoce que la tendencia alineada con el gobierno por parte de la Confederación General del Trabajo (CGT) generó la necesidad de la expresión de demanda y de lucha a partir de nuevos sindicatos disidentes: el Movimiento de Trabajadores Argentinos (MTA), la Corriente Clasista y Combativa (CCC) y la central obrera independiente Congreso de Trabajadores Argentinos, que más tarde pasó a llamarse Central de Trabajadores de la Argentina (CTA), la cual conjuga a los gremios de CTERA y ATE. En Jujuy, durante los años de mayor conflicto tiene una gran preponderancia el Frente de Gremios Estatales (FGE), el cual, entre otros gremios contaba con el Sindicato de Empleados y Obreros Municipales (SEOM), con el 'Perro' Santillán como figura rutilante en las luchas de la década. Otra de las configuraciones claves de la época a nivel político es la Multisectorial, compuesta por sindicatos, organizaciones de estudiantes y colegios profesionales. 
ciudad. Este encuadre fundacional urbano entre ambos ríos va a marcar históricamente los modos de experimentación de la ciudad, organizando en torno de éste la mayor parte de las actividades políticas, administrativas, comerciales y turísticas ${ }^{62}$ de la ciudad (García Vargas, 2000).

La influencia topográfica es un condimento más a la hora de pensar a la ciudad, no sólo por estos ríos que hacen de tabiques en la programación urbanística, sino también por toda la serie de desniveles, cerros, depresiones y veras que han sido condición de toda la expansión territorial capitalina. Cuando García Vargas (2009: 156) hace mención a una ciudad en la que según los medios 'hace falta espacio' (y modernidad) se refiere también a las dificultades que presenta (y el esfuerzo económico que supone) el terreno físico de cara a la construcción y habitabilidad. Y porque buena parte de la tierra disponible pertenece a terratenientes y a capitales empresariales privados.

Los puentes que conectan al casco céntrico con el resto de la ciudad operan como arterias conectoras de los distintos sectores y barrios, y por ellos confluyen los tránsitos entre los ámbitos barriales y el comercio, el empleo y el ocio. A grandes rasgos puede considerarse que al norte del centro se encuentran las clases más acomodadas, las imágenes más pintorescas dentro de la ciudad y la mejor calidad de acceso a los servicios; en la zona sur, en cambio, se concentra la cuota más popular y populosa de la población local con un marcado déficit en el acceso a infraestructura (Bergesio, Golovanevsky y Marcoleri, 2009b).

${ }^{62}$ El turismo en la capital provincial no tienen parangón con los enormes flujos que transitan por la región de la Quebrada de Humahuaca y, entre los atractivos ofrecidos a nivel local solo se cuentan unos cuantos edificios gubernamentales, iglesias y algunos hitos históricos del período independentista concentrados en su mayoría alrededor o en las proximidades de la plaza Belgrano (Gaona, 2014b). 
La marcada 'estatalidad' en la conformación del casco céntrico de la ciudad, sobre todo en el sector más patrimonializado en ella, se corresponde en buena medida con los designios del espacio público metropolitano, de acuerdo a lo planteado por Gorelik (1998). La casa de gobierno, la catedral, la policía provincial (ex cabildo), la legislatura provincial, edificios de orden público, el mercado artesanal, el shopping Annuar, el histórico edificio del diario Pregón y la peatonal representan nodos vitales en la experiencia jujeña, todos los cuales orbitan en torno o próximos a la plaza Belgrano.

Este espacio público, clave a la hora de interpretar los procesos de dominación y resistencia al interior de la sociedad jujeña, debe comprenderse tal como propone Gorelik (Íd.), como un horizonte en dos sentidos: horizonte conceptual que permite el cruce entre las dimensiones política y urbana; y un horizonte político, como tensión permanentemente en disputas hacia la inclusión y el derecho a la ciudad. Ambas acepciones podrían sintetizarse en la concepción que hace de lo público Kaufman (2012) quien lo concibe como una promesa.

La fractura urbana acentuada a partir de la década de los ' 90 hace parte de las lógicas del tipo de ciudad configurada a partir del neoliberalismo (Svampa, 2001; Grimson, Ferraudi Curto y Segura, 2009). Para establecer a grandes rasgos el modo en que se estructuró la ciudad de San Salvador de Jujuy, retomamos algunos de los puntos planteados por García Moritán y Echenique (1990), y retomados por Bergesio, Golovanevsky y Marcoleri (2009a), para señalar las divisiones socioeconómicas espaciales generadas en la ciudad:

- División Centro-Periferia: El nivel socioeconómico de los habitantes va descendiendo a medida que uno se aleja del centro de la ciudad; 
- División Norte-Sur: Al norte del río Grande viven los grupos más acomodados económicamente, mientras que al sur del río Xibi-Xibi los niveles socioeconómicos descienden;

- División Convexa-Cóncava: los grupos de menores ingresos se instalan "en los contornos de los lechos de los ríos, en los límites de las zonas inundables, a un nivel inferior del centro de la ciudad, mientras que las residencias de la burguesía ocupan las alturas del oeste y las laterales de las colinas del norte" (Bergesio, Golovanevsky y Marcoleri, 2009a, p. 48).

Esta "espacialización de la diferencia" (García Vargas, 2006: 6) también se tradujo manifiestamente en la señalada problemática habitacional a nivel local y provincial. Las brechas y contracciones topográficas se convirtieron así en anatomía de la topografía socioeconómica. Así, la 'falta de espacio' mencionada encontró un canal de ampliación mediante las estrategias de los sectores populares por 'ganar' terreno y tierra, no sin dificultades en la disputa por las parcelas, inaccesibilidad a servicios básicos y transporte, o condiciones de vivienda digna. Hablamos de una escalada de la acción de los sectores populares teniendo como resultado una masiva expansión de los asentamientos populares (García Moritán y Echenique, 1990) que se ubican en territorios poco valorados por planificadores estatales y sectores de mayores recursos: márgenes de los ríos y arroyos, laderas de montañas, zanjones, al costado de las rutas y caminos, ubicados cerca del sector administrativo y de mayor acceso a recursos.

El caso paradigmático de esta expansión es Alto Comedero. Este barrio, con orígenes recién en 1986, ubicado a unos cinco kilómetros del centro de la ciudad, reúne según las estimaciones censales alrededor de la mitad de los habitantes de la ciudad, es decir, alrededor de unas 130 mil 
personas (Bergesio, Golovanevsky y Marcoleri, 2009a). El carácter que adquieren sus formas de desarrollo y habitación habla a las claras del requerimiento de vivienda como fenómeno local, por otra parte, reconocible en distintas latitudes latinoamericanas.

Este terreno elevado respecto del resto de la ciudad, con desniveles y suelo arcilloso, sostiene como centro originario y jamás expropiado, al aeroclub local. La diversidad que ha operado en la expansión del barrio habla a las claras del modo de intervención por parte del Estado en los espacios periféricos de la ciudad ${ }^{63}$. Es así una conjugación entre ocupaciones de terrenos privados y loteos fiscales con construcción de viviendas precarias, loteos privados, viviendas construidas por el Instituto de Vivienda y Urbanismo de Jujuy (IVUJ), con financiamiento del Banco Hipotecario Nacional, y por cooperativas de trabajo mediante programas nacionales mediados por las organizaciones sociales (esta última modalidad implementada recién a partir del año 2004) (Fournier, 2002; Gaona, 2011). Sin embargo, la intervención por parte de los gobiernos para la expansión barrial, sobre todo en períodos electorales, no se condijo con apropiadas ampliaciones en los márgenes hasta donde llegan organizadamente los servicios.

En Alto Comedero se multiplican los reclamos por la escasa presencia de escuelas públicas, la exigüidad de servicios de seguridad regulares, la ineficacia del "puesto de salud grande" (como se llama al hospital allí radicado, gran edificio sin insumos y con poco personal), la ausencia de fuentes de trabajo, la escasez de transporte público y la carencia de pavimentación. (Bergesio y Golovanevsky, 2010: 120)

${ }^{63}$ Existe una puja histórica desde distintos sectores políticos en la ciudad por intentar municipalizar Alto Comedero. Durante 2015 se presentó el tercer proyecto que procura llevar adelante el nuevo municipio, en este caso, impulsado por lxs diputadxs del FUyO. Sin embargo, de acuerdo con declaraciones mediáticas, éste, como los anteriores intentos, no cuenta con el apoyo municipal, ni provincial. 
Existe en la evolución de ambos ámbitos a lo largo de las últimas décadas, el casco céntrico y la conformación del barrio Alto Comedero, fuerte intervención de un Estado que legitima a cada decisión un modelo de jerarquización de los espacios a través de la calidad de vida, la acentuación de las distancias a pesar de su relativa cercanía y el tipo de ciudadano que, se espera, acceda a uno u otro. Son dos ciudades al interior de una: la que está entre los dos ríos y el logotipo de la ciudad hace funcionar metonímicamente como 'la' ciudad ${ }^{64}$; la otra, aquella en la que 'implosiona' ${ }^{65}$ la población desde distintos puntos de la ciudad, la región y la provincia.

Como parte de la reconstrucción cartográfica de la ciudad, es también importante considerar los sentidos que de Jujuy se elaboran en el espacio mediático. Éste "resulta co-constitutivo del espacio social -y de sus vínculos con el espacio físico- ya que no se limita a dar forma a algo previo y ya existente sino que es parte del proceso de formación, estabilización, crítica o ruptura de la mayor parte de las figuras que se presentan al debate social" (García Vargas, 2011: 47). Así, en la reconstrucción de los sentidos hegemónicos de la ciudad, un relato especialmente eficaz como constructor y reproductor de mensajes que influyen en la manera en que nos representamos el mundo en que vivimos y nuestro entorno es aquél que producen los medios masivos de comunicación.

Aún en ciudades medianas, como la que se analiza, se comprende que la experiencia está atravesada y se hace inteligible en gran medida en los términos en los que los medios suministran

${ }^{64}$ García Vargas (2003), en un análisis semiótico acerca de los mapas de la ciudad, analiza el logotipo de la Municipalidad de San Salvador de Jujuy que ilustra únicamente los dos ríos y nueve cuadras al interior de ellos.

${ }^{65}$ Bergesio, Golovanevsky y Marcoleri (2009b) atribuyen el desborde habitacional experimentado en Alto Comedero a la marea inmigratoria proveniente de distintos sectores de la provincia a partir de la crisis socio-económica. 
la base de las 'imágenes' de la vida, las prácticas y los valores de los grupos y clases y; las imágenes, representaciones y valoraciones que hacen a la totalidad social (Hall, 2010b).

Los medios masivos de Jujuy construyen un sentido hegemónico para la ciudad y para la gente que habita esa ciudad (García Vargas, 2004, 2010; Burgos y García Vargas, 2008). La presentan como

una ciudad argentina, que es la capital de una provincia de frontera, que en ella hace falta espacio y modernidad, y también que es necesario recordar el pasado [un pasado vinculado con el heroísmo de los locales durante el proceso de independencia nacional]. (...) La ciudad se construye por oposición a otras (a algunas otras: Buenos Aires y Salta), a la naturaleza (que es también una especial naturaleza: los paisajes patrimonializados de la Quebrada de Humahuaca), y se ubica en un espacio nacional (cuyo exterior constitutivo se restringe a uno de los países fronterizos: Bolivia) (García Vargas, 2010b: 86). ${ }^{66}$

Además de algunos de los factores externos mencionados que influyen en la construcción de la ciudad, operan interpretaciones acerca de lo internamente visible y no visible. Es así como mediante una operación de recorte espacial la ciudad es circunscripta a su centro histórico y comercial. Esta identificación de la ciudad con su centro

${ }^{66}$ Otro faceta en esta caracterización hegemónica acerca de Jujuy -en contraste con otros lugares, culturas y hábitos- que retomamos en este caso de manera lateral desde la mirada de un ensayista habla de "esa otra Argentina, que no veranea en Punta del Este, pero que realiza, con la participación de vastos sectores populares, la fiesta del Tantanakuy; que no posee, como Buenos Aires, una de las concentraciones más altas del mundo, por habitante, de psicoanalistas, psiquiatras y psicólogos, y que, sin embargo, conserva profundos sentimientos religiosos, donde el cristianismo termina por perderse, sincretismo mediante, en la noche de los tiempos y donde, con excesiva frecuencia, los curanderos reemplazan a los médicos" (Espejo, 2007: 25). 
elude la mostración de los barrios, que se restringen en cambio a las noticias sobre infraestructura - en base fundamentalmente a partes de prensa de los organismos públicos - o bien al espacio de las crónicas policiales. El mapeo de actores que hacen los medios reproduce la espacialización diferencial de actores asignando lugares desfavorables para quienes escapan del rol de ciudadanos ideales para la igualmente idealizada Tacita de Plata. (García Vargas, Gaona y López, 2012: 4)

Aquello que no queda idealizado, que queda fuera de la norma, aparece en noticias encuadradas en las secciones policiales y tiene que ver con otros sectores que no son ese centro: la zona de la terminal, los barrios de la zona sur o de los distintos sectores populares de la ciudad (García Vargas, 1999). Y aquello que tiene que ver con la gestión del Estado, la obra pública que apunta a la resolución de necesidades urgentes, también se presenta en esos otros sectores; mientras que el embellecimiento, la puesta en valor y patrimonialización es presentado en el ámbito céntrico público.

A esta modalidad de construcción del espacio jujeño capitalino debemos agregar otro lente con igual influencia. Nos referimos a aquella mirada y modos de decir frente al norte del país por parte de los medios de la ciudad de Buenos Aires. En este caso, las imágenes generadas plantean una operación de sinécdoque que hace opaca la diferencia provincia-ciudad, y en general suelen reportar casi exclusivamente circunstancias que tienen que ver con situaciones de criminalización de la frontera (López, 2013), visibilización de la pobreza, o escenas de violencia social sobre todo en órbitas de la política ${ }^{67}$. También es recurrente la presentación de lo rural-

\footnotetext{
${ }^{67} \mathrm{Al}$ momento de cierre de la redacción de esta tesis (octubre de 2015), en el portal digital de Todo Noticias
} (señal de cable TN), en 19 de las últimas 20 noticias con el Tag \#Jujuy se vinculaba a militantes de la 
paisajístico-turístico en imágenes de la Quebrada de Humahuaca.

El vínculo con el resto del país se experimenta de manera compleja e inclusive conflictiva. La demanda por el reconocimiento como parte del territorio nacional se abre en el abanico de instancias reproductivas locales, tanto en lo mediático masivo (Burgos y García Vargas, 2008), como en eventos deportivos (Burgos, 2014), en festividades determinantes de la cultura popular jujeña, como son la Fiesta Nacional de los Estudiantes (Ficoseco, 2010) o el Éxodo Jujeño (Gaona, 2014c; Maya, 2014), y suele sostenerse como horizonte simbólico presente en los conflictos políticos, de beligerancia popular y ante cualquier cruce por delimitar selectivamente 'qué significa ser jujeñx ${ }^{\text {}}{ }^{68}$.

Se comprende que hablamos de la articulaciones hegemónicas en el marco de los procesos de reconocimiento e identificación en pugna, en los que diferentes formas de representación, trabajo discursivo y demarcación de límites simbólicos (Hall, 1997) operan estableciendo, no solo cierta reciprocidad constitutiva entre diferentes grupos como orden de sostenimiento, sino también la configuración contingente y localizada de jerarquizaciones entre grupos 'señalables' (Hall, 2010a).

organización barrial Tupac Amaru y a Milagro Sala con situaciones de violencia social durante el período de campaña electoral.

${ }^{68}$ Una común caracterización analítica utilizada en los estudios acerca de identidades en torno de lo jujeño es aquella que elaboraran Belli y Slavutsky, la cual, a riesgo de parecer una apreciación que por escueta puede tener atisbos esencialistas por discutir, sirve como introducción a elementos recurrentes en la autoidentificación local/provincial. Para estos autores, ser jujeño "puede tomar el orden jurídico -se es jujeño porque se nació aquí- donde la identificación distingue entre quien nació y permaneció en la provincia de aquellos que fueron migrantes temporarios. Otro modo enunciativo de marcar la identidad jujeña, por parte de los agentes es indicar rasgos, signos distintivos: el jujeño ama su tierra, celebra con unción 'el éxodo jujeño', es muy católico y venera a sus santos, etc.: o bien señala diferencias nítidas (que suelen tomar la forma de oposiciones) con la vecina provincia de Salta y con los sureños, especialmente marcado para el caso de cordobeses y porteños" (1994: 121). 
De este modo, el reclamo de pertenencia nacional

no es naturalmente unívoco y constituye un espacio político ideológico donde se enfrentan fuertes contradicciones. Bajo ciertas condiciones podrán priorizarse los aspectos más reaccionarios del discurso de la nacionalidad (la adhesión a la cultura oficial, la hostilidad contra los bolivianos), pero bajo otras condiciones puede representar la demanda de participación y democratización real de la sociedad, al amparo (de) la común membresía al sistema político. (Karasik, 1994: 69)

Esa identificación está trasvasada por lo que suponen los cuerpos mismos, como movimiento fronterizo entre lo que ‘son' y lo que los constituye por fuera de sus límites (Butler, 2008). Esa materialización depende de la propiedad reiterativa que se introduce como régimen de verdad discursivo. La formulación material existe en la medida en que su espacio de inscripción se delimita por aquello que excluye. Así, la demanda inclusiva respecto del resto del país apela a una configuración excluyente de los elementos internos.

La aparente incomodidad con la que se asume la identificación nacional en el contexto jujeño implica que 'hacerse' argentino exhorte a retomar de las prácticas tradicionales jujeñas los medios para borrar ciertas marcas negativamente valoradas. El reconocimiento, los estatutos de la existencia más legítima y más habitable, no sólo hacen ponderar ciertos modos de ser ciudadanxs, sino que accionan para velar a todos aquellxs que aparezcan negadxs de ese pretendido ser. Eventos y festividades como los mencionados -la Fiesta Nacional de los Estudiantes y la evocación del Éxodo- apelan a la construcción de un 'nosotros' que se construye también a partir de una exterioridad, ajenidad o alteridad que, si bien nublada, late 
constantemente tanto como parte del relato histórico, como de la imposición de un tipo de corporalidades admisibles -con femineidades y masculinidades admisibles- (Ficoseco, 2010) en el presente.

Por ejemplo, en el caso de la evocación del Éxodo y de las diferentes performances que 'reconstruyen' los eventos históricos, se presentan imágenes como parte de la tradición jujeña que de hecho no requieren de interlocución con algún pasado, sino más bien del margen suficiente para la habilitación al fijar los símbolos con los cuales sería posible imaginarse signos visibles que perdurarían de tal pasado. Es legitimar por vía de lo performado y lo visible tal pretendida subsistencia.

Las distintas modalidades de construcción de sentidos de ciudad que hemos presentado hasta aquí tienen que ver con la intención de narrar la ciudad y los procesos hegemónicos que en ella ocurren como una red, una "red de simultaneidades históricas" a fin de desplegarla como discurso temporalmente sucesivo (Bolle, 2008: 30). Toda esta serie de materiales nos permiten esbozar una cartografía local como punto de partida para pensar un problema político y una movilización teórica: las disputas, resistencias, convalidaciones y actualizaciones de San Salvador de Jujuy ante la controversia de sentido que supone el fenómeno de la Tupac Amaru. 


\section{LA TUPAC AMARU. EL FAUSTO JUJEÑO}

\section{1. Surgimiento y estabilización}

Los cimientos de lo que hoy se conoce como parte de la organización barrial Tupac Amaru tienen origen en la labor encauzada desde la Asociación de Trabajadores del Estado (ATE) y la Central de Trabajadores de la Argentina ${ }^{69}$ (CTA) a partir de 1999. La inserción de muchxs de lxs actuales militantes y dirigentes de la organización tiene inicio ya durante el gobierno de De Aparici en Jujuy, a fines de la década de los ' 80 , integrándose a las líneas de ATE.

Las protestas, huelgas, cortes de rutas, de calles y puentes, y diferente tipo de manifestaciones en contra de los distintos gobiernos que se precipitaron a lo largo de la década se experimentaron también como un período de formación en la beligerancia y la resistencia popular, inscribiéndose en la historia local como vía de experimentación ciudadana válida.

Muchos compañeros nuestros fueron encarcelados para que bajáramos los brazos

69 La CTA nació como central sindical autónoma y alternativa, disidente y desasociada de los sindicatos identificados con el peronismo, y contraria a las políticas neoliberales acentuadas en la década de 1990. Aunque es una central sindical, desde sus orígenes reúne características 'movimientistas', por su composición, formas de lucha y prácticas asamblearias. Podría definirse como un "movimiento social sindical" (Waterman, cit. en Giorgetti, 2010: 6). Fue fundada por Víctor De Gennaro (que fue quien recomendó a Milagro Sala empezar con la tarea territorial en la provincia de Jujuy) y Germán Abdala. La CTA, reconocida como organización sindical de tercer grado (central que congrega a sindicatos del sector, los que a su vez incorporan a organizaciones de base) reúne a nivel nacional a dos de los sindicatos más afectados por las políticas de Reforma de los '90, la Asociación de Trabajadores del Estado (ATE) y La Confederación de Trabajadores de la Educación de la República Argentina (CTERA). En Jujuy reúne, entre otros, a: ADEP, ADIUNJU, ATE, FJA, AMMAR y SOEA Ing. La Esperanza (Fuente: http://www.ctajujuy.org.ar/spip.php?rubrique4 Visto el 17-08-2010). La Tupac Amaru estuvo afiliada a la CTA hasta septiembre de 2010. 
y nos fuésemos a las casas. Pero, al contrario, a medida que íbamos a parar a la cárcel, a medida que nos pegaban, como todo coya, duro, resistíamos y la pegada de la policía la recibíamos como si fuese un galardón porque nos daba más fuerza para salir adelante y porque estábamos seguros de lo que estábamos haciendo. (Milagro Sala, Milagro en Jujuy, 2007)

El cruce entre lxs primerxs militantes de la organización se dio por dos carriles: entre las líneas sindicales mencionadas y las tribunas de la hinchada conocida como la "Lobo Sur" en los partidos del Club Gimnasia y Esgrima de Jujuy. Tal como lo grafica Burgos (2014), este club tiene una marcada escalada como marco de referencia local durante la década de los '90 a partir de haber ascendido tres categorías de manera consecutiva, hasta llegar a la Primera División ${ }^{70}$. El club se convierte en espacio de tránsito de distintos representantes de la política tradicional y de potenciación de la participación política local en general. Por allí transitan, tanto los distintos gobernantes a nivel municipal y provincial, como los dirigentes sindicales y militantes más belicosos de aquellos años. La movilización de muchxs de lxs jóvenes de aquellos ámbitos que pertenecían a distintos barrios populares ${ }^{71}$ de la ciudad se generó apelando a la búsqueda de apoyo de las luchas sindicales de ATE. Muchos de estxs jóvenes vivían en situación de calle o en condiciones precarias.

En aquel momento Milagro Sala era secretaria gremial de ATE en Jujuy y, junto con Nando

\footnotetext{
70 "Este proceso de ascenso deportivo lleva a su presidente Ulloa a manifestar 'somos la cara de Jujuy en el país"” (Burgos, 2014: 108).

${ }^{71}$ Los sectores que más se movilizaban en aquellos años eran los de los barrios San Pancho y Mariano Moreno.
} 
$\operatorname{Acosta}^{72}$ (secretario general), encabezaron las primeras acciones comunitarias por fuera de la beligerancia territorial para contrarrestar la situación de los sectores empobrecidos, trabajadores desocupados y empleados estatales en situaciones precarias en los barrios populares de la capital provincial. Así, las primeras tareas de organización comunal tuvieron que ver con la generación de copas de leche (merenderos) en algunos barrios de San Salvador de Jujuy.

Cuando yo era delegado de mi barrio yo era como toda la changada que está acá. Éramos cuatro en la copa de leche. Estaba el Papa, yo, el loco Guille y uno más. Y para todo el mundo éramos cuatro locos. Un día me acuerdo que vamos a la CTA y la Milagro dice "hay que ser solidarios y empezar a laburar con los chicos en los barrios” y nosotros “¿y cómo hacemos?”, “ustedes háganlo y a la mierda, no me interesa, háganlo, quiero que los chicos de los barrios tengan qué comer" porque en el barrio el que pasó cosas jodidas, pasó cada hambre. Y fuimos cuatro locos, hicimos la copa de leche, un día abrimos las puertas de la casa del Papa, y pum, un tacho afuera. Ya habíamos ido censando por todas las calles y vinieron los chicos y toda la gente nos miraba. “¿Estos son peronistas o radicales?” (...). Íbamos, buscábamos a los chicos, los alimentábamos y los íbamos a dejar a la casa. Mirá el laburo que hacíamos nosotros, los vagos. En el barrio decían "eh, qué les pasó a estos" [semejantes hijos de puta-agrega Chespi, un compañero a su lado-]. No entendían. (...) Y se juntaban setenta, ochenta chicos, cien, y no nos daba a vasto, (...) y se agregaron otros vecinos que les gustó la idea (...) y así

\footnotetext{
${ }^{72}$ Ambos dirigentes se conocen militando en la Juventud Peronista, poco tiempo después de que Sala saliera de la cárcel, en donde había movilizado un motín en reclamo por modificaciones en la administración de la comida en el sistema penitenciario local.
} 
abrimos otra copa de leche, y otra, y otra. Lo poblamos. (...) Los mismos peronistas y radicales que nos puteaban terminaron laburando adentro de la copa de leche. Se afiliaron a la CTA y abrieron su copa de leche. Les cambiamos el bocho a todos. Eso es parte del poder. Ahora todo el barrio es CTA. De la primera copa de leche, ahora muchos son delegados [de copa de leche] o presidentes [de cooperativas]. Éramos cuatro locos, ahora todo San Pancho está loco. (Pilo Mansilla $^{73}$, Construyendo un Milagro, 2005)

Yo si tenía plata ponía el azúcar, el que no tenía iba a buscar la leña al monte, el otro se encargaba de hacer el fuego, y no teníamos ni un bolsón, lo hacíamos así a pulmón. (Militante, Milagro en Jujuy, 2007)

Se fueron organizando así réplicas de la tarea de las copas de leche en distintos barrios de la ciudad: El Chingo, Punta Diamante, Barrio Norte, Villa San Martín, etc. Muchxs militantes que permanecen entre las masas de la organización en la actualidad se reconocen como parte de esas primeras acciones territoriales. A medida que se fueron sumando, se fueron así también disputando la entrega de bolsones de mercadería y planes $\operatorname{Trabajar}^{74}$, los cuales, en una práctica

${ }^{73}$ Este relato corresponde a un militante que formó parte de la organización desde los primeros años. Mansilla perteneció a la Tupac hasta el año 2011, cuando encausó el proyecto de una nueva organización social, la agrupación "La 27", la cual se declaraba en disidencia a la Tupac Amaru, pero en apoyo al gobierno nacional y al partido justicialista.

${ }^{74}$ La respuesta del menemismo a partir de 1997 y de los sucesivos gobiernos de De la Rúa (1999-2001), Rodríguez Saá (2002) y Duhalde (2002-2003) a la conflictividad social fue la oferta de planes laborales mediados en un primer momento en mayor medida por municipios y 'punteros'. La elección de los beneficiarios y la ejecución de las contraprestaciones quedaba sujeta así a decisiones atomizadas. A partir de la presidencia de De la Rúa, sin embargo, se inicia el proceso de traspaso de algunos de los planes a la gestión de las organizaciones sociales, las cuales recién a partir de ese momento comienzan a ser reconocidas como actores políticos - con creciente capacidad de administración de recursos y de movilización social. 
habitual de las organizaciones sociales, se dividían entre dos o más militantes.

En este sentido, la CTA como central sindical fue de las primeras en notar la potencialidad organizativa de lxs desocupadxs y percibió esta necesidad de una inscripción territorial de las clases populares. Fue así como comenzaron a organizarse proyectos comunitarios en la ciudad. A las copas de leche, se les sumaron los roperos comunitarios y las huertas. Y así se fue llevando adelante una doble tarea de reproducción de experiencias comunitarias, por un lado, y de consolidación de la organización colectiva a nivel territorial, por el otro. La cantidad de personas que se fueron incorporando durante los primeros años dio lugar no solo a ampliar el protagonismo barrial, sino también a constituirse como una base social emergente que pudiera demandar de forma directa la intervención del Estado para solucionar situaciones apremiantes en la provincia.

Ya hacia 1999 estxs militantes, liderados en gran medida por Milagro Sala, se organizan configurando los primeros cuadros de la organización barrial Tupac Amaru. Las dos opciones en pugna para dar nombre a la organización fueron las de Che Guevara y Tupac Amaru. En asamblea ganó la designación con el nombre del rebelde indígena porque consideraron que tenía más que ver con el contexto local. Sin embargo, ambas imágenes, sumadas a la de Eva Perón son parte de la triada simbólica más habitualmente reconocida en la iconografía de la organización hasta la actualidad ${ }^{75}$. Más allá de esto, la Tupac Amaru fue reconocida e identificada fuertemente como la organización de la CTA al menos hasta bien avanzada la

75 "Evita, por lo que hizo Evita por los que menos tienen; el Che, que decía que había que endurecerse pero no perder la ternura jamás con el tema de la disciplina, que la libertad es una cosa y el libertinaje es otra; Tupac Amaru por los pueblos originarios" (Milagro Sala, Algo está cambiando, 2012). 
década del 2000. Sus propios militantes - en entrevistas y conversaciones durante el campo-se identificaban de esta manera. La acción colectiva territorial se ve así marcada históricamente por sus orígenes sindicales y en torno de la demanda al Estado. Desde la gestación del movimiento podemos distinguir tres vías de inscripción política claves para la interpretación de esta organización, y de muchas de las que se fueron institucionalizando en el umbral entre una década y la otra: la raíz combativa sindical de origen; el corte justicialista con el que se identificaban muchxs de sus militantes ${ }^{76}$; y la importancia de la inscripción territorial barrial cotidiana.

Llega entonces el período identificado históricamente como de mayor declive económico y debacle de la institucionalidad política a nivel nacional, diciembre de 2001. Sin embargo, la experiencia de la crisis económica y política de aquel año se experimentó a nivel local como línea de continuidad de un conflicto de muy larga data, que, en cambio, encontró a la provincia en una relativa estabilidad gubernamental habiendo sostenido por primera vez en muchos años a un mismo gobernador en el poder -durante los tres años antecedentes. No obstante, la crisis económica se sostuvo ya como marca estructural de la experiencia local y la población bajo la línea de pobreza para ese año alcanzaba un 68,1\%, de acuerdo con el INDEC (Lagos y Gutiérrez, 2009).

El año 2003, con la asunción de un nuevo gobierno peronista a nivel nacional a cargo de Néstor Carlos Kirchner, el cual había ganado las elecciones con un muy bajo nivel de legitimidad,

\footnotetext{
${ }^{76}$ Sin embargo, se hallaban ante un gobierno peronista a nivel provincial y nacional que desconocía la tendencia histórica del movimiento en favor de los trabajadores y los sectores más vulnerables (Kindgard, 2009), lo que desdibujaba así el horizonte partidario como fórmula de la acción militante por el sostenimiento de dichos principios.
} 
encuentra a la organización en ciernes frente a la consolidación de los métodos autogestivos, comunitarios, asamblearios y con una fuerte dinámica de toma de decisiones de manera colectiva, además del manejo hábil de los métodos de lucha pública y la pericia de muchxs de ellxs en la gestión de recursos frente al Estado por su involucramiento con los sindicatos locales ${ }^{77}$.

La percepción del gobierno nacional acerca del cooperativismo como vía de generación de empleo digno y la estimulación de la participación se sumó como parte de las estrategias de construcción transversal por parte del recientemente asumido gobierno kirchnerista. La transversalidad, retomando a Torre (2004, cit. en Forni y Catronuovo, 2014), refiere a la forma alternativa de construcción de legitimidad y respaldo puesta en marcha por el presidente Kirchner con vistas a incorporar a sectores de un peronismo de izquierda, a movimientos de izquierda no peronistas (ambos sobre todo congregados en las figuras de las nuevas organizaciones sociales), en negociación con las líneas más tradicionales y hegemónicas del justicialismo que lo habían apoyado de manera parcial para su ascenso al gobierno. Así, la doble vía, la posibilidad de acceso a recursos para la producción -y no el mero asistencialismo que caracterizara el perfil de buena parte de los programas anteriores- y el acercamiento político a un nuevo gobierno a nivel nacional, dispuso a la organización a un nuevo período en su historia.

Una interpretación un tanto simplista acerca de los primeros momentos de vínculo entre organizaciones sociales de bases peronistas y el nuevo gobierno las ubica integradas,

${ }^{77}$ Este argumento acerca de la destreza y capacidad en la negociación y gestión de recursos en torno del Estado por la experiencia sindical y municipal de muchos de ellxs es sostenida también por Battezati (2012). 
disciplinadas y cooptadas desde un primer momento a partir del relativo éxito de los programas productivos y de asistencia implementados (Svampa y Pereira, 2003 [2009]). Esta lectura, acerca de un adormecimiento en los movimientos y en la lucha por parte de los sectores populares, desconoce no sólo la historicidad disruptiva de la movilización colectiva, sino también el tenor periódico que adquieren esas relaciones de fuerza y las modificaciones que se pueden configurar entre un modelo de Estado y otro. Con esto queremos decir que los movimientos sociales locales se constituyen como actores que confrontan al Estado en razón de redefinirlo de manera integracionista o inclusiva. Lo revolucionario en los movimientos de este tipo es lograr la interrupción en el curso histórico de un tipo de Estado.

Hoy le damos las gracias al Gobierno, pero el día que nos falle, vamos y les pateamos la puerta. (Presidenta de cooperativa, entrevista de julio de 2008)

Hacia fines de 2003 se consigue la aprobación para participar del Programa Federal de Emergencia Habitacional ${ }^{78}$, lo que convoca a la coordinación para la organización de cooperativas de construcción de viviendas. Esta sería la primera experiencia de manejo autónomo por parte de la organización de fondos genuinos dispuestos directamente desde el Estado Nacional destinados a la producción. Sería también la puesta a prueba de la administración de puestos de empleo por parte de la organización, en lugar de los históricos planes de desocupados.

78 "El Programa busca solucionar la emergencia habitacional y laboral a través de la participación de los beneficiarios del Plan Jefes y Jefas de Hogar y desocupados, organizados en forma de Cooperativas de Trabajo, para la construcción de viviendas. De esta manera, la política del programa resuelve simultáneamente problemas habitacionales y laborales, permitiendo aplicar fondos, actualmente destinados a subsidios por desempleo en la emergencia, a la generación de un proceso productivo que permita la reinserción social y laboral." http://www.vivienda.gob.ar/emergencia/descripcion.html visto por última vez el 05/10/2015) 
Después de pelearla tres días en Buenos Aires nos dan para hacer las trescientas viviendas y, típico de porteño, nos dicen "si lo hacen mal no vengan a joder más". (Milagro Sala, Construyendo un Milagro, 2005)

En asamblea, se conformaron de manera casi inmediata cincuenta cooperativas de trabajo, se solicitó a la Legislatura Provincial la cesión de los primeros terrenos en el barrio Alto Comedero y se presentó un proyecto de ley para que la provincia comprara tierras para futuras ampliaciones en la construcción en el mismo barrio. La efectiva obtención de las tierras requeridas se propició mediante la toma de la Legislatura y las habituales $\operatorname{carpeadas}^{79}$ y movilizaciones en la zona que comprenden la plaza Belgrano, y las intersecciones de las calles San Martín y Gorriti (frente a la casa de Gobierno y la Legislatura provincial).

Tal como hemos planteado en la periodización establecida para el análisis de la organización, a partir del momento de inicio de las tareas de construcción de viviendas de forma masiva se da una escalada exponencial de crecimiento en los cursos políticos de movilización popular.

Hacer de dispositivo por el que drenaron las más vastas formas de demandas de clase históricas a nivel local le permitió a la organización la acumulación de un capital simbólico que se fue evidenciando de manera más pronunciada a lo largo de los años. La gestión frente al Estado, la alineación convencida a la par de un modelo de gobierno a nivel nacional y las modulaciones estratégicas en la disputa con el poder político provincial, le permitieron consolidarse como vía

79 La Tupac Amaru se caracterizó históricamente por incrementar la presión de los reclamos por medio de los acampes en la plaza principal de la ciudad. Este tipo de metodología de protesta requiere de un gran esfuerzo y organización por parte de lxs militantes y delegadxs ya que, además de las ollas populares que se sostienen para todxs lxs presentes, en muchos casos se movilizan familias enteras por días desde sectores alejados de la ciudad hacia el casco céntrico. 
hegemónica alternativa, tanto en lo que refiere al desarrollo material a partir de los recursos del Estado, como a la disposición masiva de militantes políticxs reunidos en causas comunes.

Ya establecida como poder hegemónico alternativo y síntesis simbólica de los deseos y demandas de un fragmento de los sectores populares locales, la Tupac dio varias muestras de dicho salto: la organización de la Constituyente Social en 2008, la marcha de los pueblos originarios en el bicentenario argentino ${ }^{80}$ en 2010 , y la conformación de un partido político y frente electoral -el Partido por la Soberanía Popular (PSP) y el Frente Unidos y Organizados por la Soberanía Popular ${ }^{81}$ (FUyO) a partir de 2013.

El análisis de esta nueva encrucijada traducida en configuración política partidaria tiene el evidente componente del movimiento que ha asumido al Estado como horizonte de todas las luchas que buscaron reconfigurarlo, expandirlo y abrirlo en razón de las solicitudes populares. Pero nos parece destacado señalar también una experiencia en alguna medida análoga que corresponde a un emergente andino de carácter en muchos puntos comparables. La conformación del Movimiento Al Socialismo (MAS) en Bolivia ha estado permanentemente en la perspectiva transformadora que ha encarado el movimiento local. Stefanoni y Do Alto definen al MAS como un

archipiélago de movimientos sociales y sindicales con ritmos, culturas políticas y objetivos no siempre coincidentes ni fáciles de articular, y con fronteras

${ }^{80}$ Este acontecimiento será parte del análisis del capítulo 7 de la tesis.

${ }^{81}$ El cual ha incluido al PSP, al Movimiento de Renovación Cívica, al Partido de la Concertación y a Quiaqueños, en las elecciones legislativas de 2013; y al PSP, al Movimiento de Renovación Cívica, al Partido Comunista, al Partido por la Diversidad, y a Por un nuevo San Antonio, en las elecciones generales de 2015. 
ideológicas más amplias y pragmáticas que conservan referencias nacionalistas revolucionarias al tiempo que incorporan un componente étnico-cultural casi inexistente en la izquierda clásica local. $(2006,19)$.

La conformación del movimiento en tanto que partido político tiene la rúbrica de ambas expresiones: las bases de la justicia social peronista y la raíz comunal andina. Esta indigenización del peronismo le agrega a la cuota histórica de clase un componente étnico novedoso. La acumulación de la experiencia movimientista de cara al Estado, sumada a la experiencia sindical de militancia, y al roce y negociación permanente con las dirigencias de los partidos políticos provinciales y nacionales han allanado parte del camino hacia la conformación del partido. Esta es una traducción institucional de una acumulación histórica instituyente.

Existe un voto corporativo que se traza como parte de las líneas de militancia y de sostenimiento de los objetivos programados por la organización. La elección de los representantes se decide también como parte de las decisiones asamblearias, y como tal, se asume que debe ser respetada y convalidada en el voto.

El resultado del viraje de la organización hacia el partido ha sido eficaz en el proceso eleccionario, permitiendo el ingreso de seis diputados provinciales y una serie de concejales en distintas localidades de la provincia en los primeros dos comicios de los que participaron (20132015). Con un $12 \%$ y un $8 \%$ de los votos en las últimas dos elecciones se convirtieron en tercera y cuarta fuerza, respectivamente. Por su parte, Milagro Sala, electa diputada provincial en 2013, se convierte en Parlamentaria del Mercosur por el Frente para la Victoria a nivel nacional en 2015. En este caso, ingresa en quinto término con un $37 \%$ de los votos a nivel nacional. Sin 
embargo, esta elección también conlleva la derrota histórica del justicialismo a nivel provincial, después de treinta y dos años de mandato ininterrumpido, frente al contrapoder radical, que catapulta a Gerardo Morales como nuevo gobernador.

\subsection{La construcción de la (otra) ciudad a partir del fenómeno Tupac ${ }^{82}$}

Tal como fue planteado, a partir del Plan de Emergencia Habitacional se dio inicio a la obra que un par de años después sería conocida como el cantri de los pobres, en uno de los habituales gestos paródicos por parte de la organización. La construcción de viviendas se inició formalmente en el año 2004. Hasta enero de 2015 el barrio llevaba construidos veinte sectores de viviendas habitadas (alrededor de cuatro mil viviendas solo en ese sector de la provincia) ${ }^{83}$.

Entre los relatos de muchxs de lxs obrerxs se da cuenta de la elección de un terreno inhóspito, con desniveles y malezas de todo tipo ubicado en Alto Comedero, pero que permitía una vista panorámica de los cerros más cercanos. Estos terrenos se ubican en el extremo sur de Alto Comedero, a un costado de la Ruta Nacional 9, antes del río Los Alisos. El barrio limita con asentamientos, un barrio del sindicato de los empleados de comercio y la feria de ropa americana Virgen de Urkupiña.

${ }^{82}$ Los fragmentos de peso descriptivo en este apartado y los subsiguientes responden a la necesidad de satisfacer una comprensión de la magnitud de la Tupac Amaru a nivel material productivo y de injerencia en la vida de lxs sujetxs.

${ }^{83}$ De acuerdo con el Anuario 2014 de la organización, además de las cuatro mil que corresponden al cantri, se llevaban construidas otras cuatro mil repartidas entre distintos barrios de la localidad capital, Palpalá, Perico, El Carmen, La Esperanza, Monterrico, Calilegua, Humahuaca, Libertador Gral. San Martín y San Pedro. Esto lleva el número a ocho mil viviendas en total en toda la provincia. 
La primera etapa se construyó en la mitad del tiempo estipulado y así se fueron incorporando en los meses y años subsiguientes distintas etapas de viviendas ${ }^{84}$. A partir de la segunda etapa se re-administraron los recursos para las obras mediante la conformación de fábricas de materiales propias: la fábrica de caños de hormigón, bloques y adoquines, la metalúrgica, y la de muebles de caño facilitaron la obtención de elementos fundamentales para la construcción con precios abaratados.

Las fábricas del cantri fueron construidas enteramente por la organización. A diferencia de un proceso metropolitano de recuperación de fábricas cerradas durante los años precedentes, mediante la vía autogestiva y cooperativa, en este caso, se montaron emprendimientos enteramente nuevos en un territorio impensado como polo productivo local -un barrio construido por desocupadxs en Alto Comedero-.

Los compañeros nuestros han aprendido. Es impresionante ver que los compañeros para aprender a hacer las puertas y ventanas se han ido camufladamente a una empresa metalúrgica a aprender. $\mathrm{Y}$ una vez que aprendieron bien -estuvieron dos meses ahí-, vinieron y les enseñaron a los compañeros nuestros. Nosotros no teníamos ni idea cómo se construía. (...) Teníamos lo mejor en maquinaria, siempre compramos lo mejor, pero entendíamos muy poco. (...). Esto nos sirvió para entender que a medida que pasa el tiempo cada compañero se tiene que ir perfeccionando para enseñarles a los que vienen atrás. (Milagro Sala, En obras, 2012)

\footnotetext{
${ }^{84}$ Un análisis más detallado acerca de lo que respecta a las tareas y labores por parte del sector obrero de la organización será presentado más adelante en este capítulo.
} 
Esta serie de emplazamientos productivos estuvieron y están dedicados tanto al abastecimiento de las obras de construcción, como a la venta abierta al público en general. Así, las fábricas operan también en producción con empresas, otras fábricas y escuelas del medio local, y, en el caso de la fábrica textil, con un local de venta propia en el centro de la ciudad.

En lo que respecta a las casas, sabemos que el derecho a la vivienda y la noción de trabajo digno están eminentemente alojados en los orígenes del peronismo, son parte de sus bases y hasta la actualidad perduran como horizontes del deseo ciudadano. En el caso argentino, la posibilidad de acceso masivo a la vivienda opera además como una de las demandas más fundamentales hacia el Estado. Sin embargo, la eficacia estatal en la intervención en favor de la vivienda, como hemos presentado en la descripción de la estructuración urbana de los últimos años en la provincia realizada en el capítulo 3, ha demostrado un gran déficit. El escaso oficio por parte del poder estatal para dar respuesta a estas necesidades, y la expansión y predominio del mercado en la definición del acceso a la tierra, ha generado un nivel de conflictividad por la tierra que deja como saldo no sólo experiencias trágicas por las expresiones masivas más categóricas y exacerbadas de la real carencia de oportunidades ${ }^{85}$-y la reacción violenta de la fuerza estatal-, sino además toda una huella histórica colectiva de trayectorias resignadas a las condiciones más pobres en el habitar: hacinamiento, migraciones continuas, despojos y desalojos, desamparos, resignación a situaciones prolongadas de violencia familiar y de género,

${ }^{85}$ Los últimos dos episodios de mayor repercusión en la disputa por la tierra en Jujuy se dieron en los años 2011 y 2012. El primero, en julio del 2011, en la ciudad de Libertador Gral. San Martín, más específicamente, en terrenos propiedad del Ingenio Ledesma, cuando unas quinientas familias accionaron para la ocupación de quince hectáreas requeridas desde hacía años a la empresa, la cual tiene cercada a la localidad entera por terrenos de su propiedad. La toma y la intervención para el desalojo por parte de la policía, dejaron un saldo de cuatro muertos. El segundo episodio, también en el interior de la provincia, en este caso en Humahuaca, se dio a modo de enfrentamiento entre representantes de la organización social Tití Guerra y vecinos de la localidad, dejando como saldo trágico una muerte. 
fluctuaciones permanentes en las convivencias, albergues provisorios y en condiciones funestas. Cada una de estas experiencias no es expresada ligeramente, sino que es confirmada en relatos dramáticos por parte de lxs militantes.

De esta manera, del otro lado de estas experiencias, se construye la ilusión de la vivienda no solo como un instrumento de reproducción cotidiana necesario, sino que se consagra como un símbolo. La vivienda es en efecto uno de los bastiones del discurso modernista. Aún más allá de la reivindicación en tanto que derecho ciudadano establecido en demanda desde hace décadas, la vivienda se sitúa de manera radical fundante en la organización de la vida de las personas: es la posibilitadora de las convivencias -sean o no familiares-, opera como pivote espacial de los tiempos de la reproducción cotidiana, dibuja las fronteras del resguardo privado frente al avasallante ámbito público, se presenta con la perspectiva de la a veces inusual posibilidad de perdurabilidad, etc.

Para la continuidad del análisis acerca de la construcción de la ciudad que venimos elaborando a partir de esta experiencia política popular, además de la vivienda y la fábrica, se distinguen toda una serie de materializaciones que hacen a una programática alternativa para desarrollar y habitar la (otra) ciudad.

En este sentido, es fundamental para la Tupac el rol que cumplen las copas de leche, no sólo como sostenes de una parte de la alimentación de miles de niñxs en toda la provincia, sino por ser el sistema más integral de organización al que responden lxs militantes. En la actualidad la Tupac cuenta con más de 1200 copas de leche en toda la provincia. La organización de cada copa de leche está a cargo de unx delegadx y un sub-delegadx quienes, a partir de esta función, 
tienen la responsabilidad y el derecho a participar y tener voto en las asambleas generales. En algunos casos también existe la figura de tesorerx de la copa, dado que la gestión y organización en cada una de ellas es disímil. La capacidad y el tamaño responden a la cantidad de afiliadxs, el uso de la mercadería distribuida por la Tupac para el sostenimiento de las copas y la autogestión de recursos por parte de cada una de ellas.

Las copas de leche, los roperos comunitarios y las huertas son tareas fundamentales en las experiencias de trabajo comunitario en el barrio y en distintos puntos de la ciudad. El comunitarismo, como otra de las características que hacen al fortalecimiento de los lazos sociales, supone "un espacio de integración de diferentes grupos" que comparten un mismo horizonte político, como actores sociales diferentes pero reconociéndose con una misma obligación de intervención política (Mata, 2009, p. 29) ${ }^{86}$.

En la sumatoria de obras, desde la organización reconocen haber erigido el primer Centro Integral Comunitario (CIC) de la Argentina, construido en 45 días. En algún momento funcionó como guardería ${ }^{87}$, también como jardín de infantes y en la actualidad está dedicado sobre todo a la atención médica. Posee ocho consultorios y un laboratorio de análisis clínicos. La atención

${ }^{86}$ Esta primera noción de lo comunitario se hace sin perder de vista la complejidad ontológica de una experiencia de este tipo y los debates contemporáneos por la ruptura de todo tipo de esencialismos y desconocimiento de la alteridad en su nombre (Nancy, 2000; Blanchot, 2002). Esto es, tener presente que lo comunitario y la comunidad están constituidos por la paradoja entre lo común y lo individual, dada la contradicción que provoca una noción que se mueve entre lo propio y lo común, en la antinomia del individuo (en el orden de las lógicas en la que lo comprendemos contemporáneamente) y la comunidad. La apuesta por lo comunitario tiene el problemático horizonte siempre presente de incompletitud (Blanchot, 2002) pero se concibe como expectativa política colectiva.

${ }^{87} \mathrm{Si}$ bien, cabe aclarar que estos espacios comprometidos con la promoción y el cuidado de niñxs son institucional y estatalmente reconocidos como Centros de desarrollo infantil, entre lxs militantes, afiliadxs, trabajadorxs, y padres y madres fueron siempre mencionados y reconocidos como guarderías. Dado el caso, los nombramos de esta manera en la tesis. 
es abierta y gratuita. En 2010, solo ese centro de salud reunía la atención de 30 médicos entre las distintas especialidades. El primer objetivo del CIC construido fue "que no haya ningún chico desnutrido" (Milagro Sala, En Obras, 2012).

Uno de los edificios más importantes del barrio corresponde al Centro Modelo Integral de Rehabilitación (CEMIR) "Sergio Chorolque", un espacio destinado a la integración, rehabilitación y estimulación de niñxs, jóvenes y adultxs con capacidades diferentes. El nombre elegido en asamblea corresponde a uno de los hijos de Milagro Sala, quien, según el relato de lxs trabajadores, fue el impulsor del proyecto. Está inspirado en un centro con las mismas funciones en La Habana y el plano de aquel edificio fue replicado en la obra construida en el cantri. Es el único de carácter público y gratuito en toda la provincia, y ofrece atención fonoaudiológica, kinesiológica, fisioterapéutica, psicológica, odontológica y clínica, además de contar con docentes preparadxs para la estimulación temprana. Asisten a lo largo de la semana alrededor de 115 personas ${ }^{88}$, muchas de las cuales hacen uso todos los días de las instalaciones. Cuenta con diferentes espacios pedagógicos, un comedor, una cancha de básquet y fútbol, un parque adaptado a las capacidades de quienes asisten y una ambulancia propia para permitir el transporte de quienes concurren desde sus viviendas hasta el CEMIR.

Así también el barrio cuenta con un Salón de Usos Múltiples (SUM): un espacio destinado a las funciones de comedor comunitario sobre todo para lxs niñxs de la guardería y ancianxs. Posee un área de grandes dimensiones dedicado a la cocina, equipada con una cocina industrial que está funcionando de manera permanente para las distintas comidas a lo largo del día

${ }^{88}$ De acuerdo con entrevistas realizadas con el personal en ambos años, para 2010, se atendían alrededor de 70 chicxs; para 2015, la cifra ascendía a 115. Esto habla también del crecimiento sostenido de la atención. 
destinadas a lxs chicxs de la guardería. También se realizan eventos y festejos allí. Las guarderías, que están ubicadas en el edificio colindante, están provistas con cunas, televisores, reproductores de video, colchonetas de ejercicios, juguetes y pizarrones. En cada una de las salas, organizadas por meses y edades, trabajan dos responsables del cuidado-siempre mujeres, en muchos casos, obreras embarazadas que son reubicadas durante los meses de embarazo a estas tareas.

Uno de los últimos grandes edificios construidos por la organización en el barrio es el Centro Cultural Tupac Amaru, el cual cuenta con un cine teatro, una sala de computación y distintas salas utilizadas para el dictado de talleres ${ }^{89}$. El Centro funciona de 8 de la mañana a 23 horas, con dos primeros turnos para niñxs ${ }^{90}$ y un último turno dedicado a lxs adultxs que trabajan en el barrio. Así también, se organizan ciclos de cine-debate, se proyectan películas de circuito comercial de forma gratuita todas las semanas, se hacen espectáculos musicales con la presentación de artistas populares de talla nacional, obras de teatro y encuentros de debate y reflexión sobre 'Costumbres propias'.

La posibilidad de acceder a una oferta gratuita de formación cultural, de desarrollo de aptitudes por medio de pedagogías comunitarias, y a consumos culturales diversos en el propio barrio supone una transgresión en tanto que reivindicación del bien público. En la medida en que históricamente se ha mercantilizado el acceso a la imagen y la palabra como insumos culturales,

${ }^{89}$ Se estipula que niñxs, pre-adolescentes y adolescentes pasen horas a contra-turno escolar en el Centro. Las primeras horas del turno dedicadxs a hacer las tareas escolares con docentes que lxs acompañan y las restantes, entre talleres de música, cerámica, fotografía, danzas, gimnasia, informática, etc. El grupo de niñxs que se inserta en este tipo de actividades es reconocido desde hace años como Los Tupaqueritos.

${ }^{90}$ Lxs niñxs con un promedio de más de 7 en la escuela reciben una beca económica. En este Centro intentan llevar un control sobre el rendimiento y la asistencia de lxs alumnxs de la escuela Bartolina Sisa. 
la posibilidad de apropiación y uso por la vía comunitaria y pública, además del entrenamiento en la palabra reflexiva sobre dichos consumos, opera no solo dinamizando a lxs jóvenes como productorxs y consumidorxs críticos, sino que además desdibuja la naturalización de que dichos consumos son imaginables solo por vía del valor comercial.

La práctica política y cultural de las organizaciones sociales (...) es expresión y parte fundamental de un proyecto de cambio para transformar la producción de sentido y las normas del intercambio simbólico que configuran esa trama social que busca alterar. (Gardella, 2010: s/d)

Esto permite disputar una modificación simbólica en los márgenes de comprensión entre economía, cultura y comunicación (entre circulación y producción) mediante un nuevo modelo de acceso a la forma cultural (sea ésta a modo de productor o de consumidor). El mapa barrial y urbano se modifica al imaginar las condiciones para el acceso -y para un tipo de acceso- a la vuelta de la esquina en un barrio popular. Esto hace parte también del derecho a la ciudad.

Seguramente, la obra de mayor magnitud visual en el cantri, la que genera el impacto más apreciado y la que muchxs habitantes destacan como de mayor ostentación y beneficio sea el parque temático, el parque acuático y la réplica del templo de Kalasasaya ubicados en conjunto en la órbita central del barrio. Una búsqueda crítica de lo que supone el parque será llevada a cabo en un momento posterior de la tesis. 


\title{
4.3. Enraizar la lucha. La educación, la salud y las obras en el centro de la ciudad: la sede central y los galpones recuperados
}

\author{
"Voy a confesar algo, este era mi sueño porque cuando iba al colegio me enseñaban \\ inglés. Teacher, qué teacher; o me enseñaban francés. No terminaba de conocer \\ Tilcara pero ya me obligaban a que sepa francés. Mi sueño era construir un colegio \\ donde cada uno de ustedes aporte y diga lo que sienten con la plata que sobró de las \\ cooperativas. Porque antes nos decían que los negros, los piqueteros, los quemagomas, \\ los que marchamos no sabíamos pensar. Eso nos metían en la cabeza"
} Milagro Sala, acto de inauguración Colegio Germán Abdala, 2007

Las instituciones dedicadas a la educación vinculadas con la organización son de gestión social. La educación en la organización fue pensada inicialmente sobre todo destinada a la formación de lxs jóvenes y adultxs que conformaban las copas de leche y lxs trabajadorxs de las distintas cooperativas. Desde el fomento a la estimulación de la primera infancia, pasando por el nivel inicial, primario, secundario y terciario, además de la implementación del Plan FinEs ${ }^{91}$, la gestión de becas, hasta la oferta de acompañamiento con clases de apoyo y talleres, la Tupac ha concebido como uno de sus objetivos primarios que sus militantes $-\mathrm{y}$ el conjunto de la población que haga uso de la red educativa ofertada- atraviesen y concluyan el sistema educativo formal y no formal. La oferta está adecuada a atender las particularidades

${ }^{91}$ El Plan de Finalización de estudios Primarios y Secundarios para jóvenes y adultos generado por el Ministerio de Educación de la Nación a partir del año 2006 (Ley de Educación Nacional N²6.206). 
socioculturales, laborales, contextuales y personales, además, de procurar constituirse como ámbito inclusivo de estudiantes expulsadxs o excluidxs de otros espacios educativos formales en la provincia.

En la escuela primaria Bartolina Sisa se reúnen nivel inicial y los siete años de educación primaria que funcionan también a contra-turno con talleres de carpintería, técnicas agropecuarias, artes, deportes, danzas e informática -casi todas estas actividades llevadas a cabo en el Centro Cultural Tupac Amaru ubicado en el mismo barrio-- A esta escuela asisten alrededor de ochocientos cincuenta alumnos. Se ofrece allí también, con el nombre de Centro de Educación Integral de Jóvenes y Adultos, un programa de educación primaria para jóvenes y adultxs al que asisten cuatrocientos sesenta personas.

Tanto la escuela, como el colegio secundario Olga Arédez se encuentran ubicados en el centro del cantri. El colegio secundario ofrece un bachillerato orientado a adolescentes hijxs de lxs cooperativistas que trabajan en el barrio, de barrios cercanos y para adolescentes expulsadxs del sistema educativo tradicional. A este colegio asisten setecientos noventa alumnxs. El edificio destinado exclusivamente para este colegio se encuentra en construcción desde hace unos años en una obra de magnitudes grandilocuentes frente a la réplica del templo de Kalasasaya. Se pretende albergar a mil quinientos alumnos en cada turno escolar (mañana, tarde y noche).

El Colegio Germán Abdala para jóvenes y adultos funciona desde el año 2003. En el año 2007 se inauguró en el centro de la ciudad, ubicado frente a la sede central de la Tupac, el edificio destinado a este bachillerato. A este colegio asisten un gran número de obrerxs y cooperativistas después de terminada la jornada laboral, y su plan de Estudios está orientado hacia la 
planificación de Proyectos Sociales y Productivos de la Economía Social y Solidaria. Además de la currícula clásica de un programa de estudios, son materias obligatorias en la enseñanza las materias de "Autoestima", "Historia y cultura de Jujuy y de los pueblos originarios" y "Lucha del movimiento obrero". Cuenta en la actualidad con una matrícula de dos mil doscientos alumnxs.

Al instituto terciario Tupac Amaru, fundado en el año 2010, asisten alrededor de mil ochocientos alumnxs y cuenta con cinco tecnicaturas integradas a las necesidades y proyecciones laborales de lxs cooperativistas: Agente sanitario y promotor de la salud; Diseño y producción de indumentaria; Economía y desarrollo local; Enfermería profesional; y Turismo.

La sede central, además de ser un punto neurálgico en las actividades administrativas de la organización (Oficina de Cómputos, de Cooperativas, la sala de Asambleas, etc.), cumple con una serie de funciones sociales clave en lo que es la oferta de asistencia, promoción y toma de la palabra constituida en la actualidad. De manera destacada, cuenta con un museo temático de pueblos originarios. Así también posee una pileta climatizada, una cancha cubierta de hockey, básquet y vóley, la radio comunitaria Fm Pachamama, las oficinas de asesoría legal, la biblioteca, las salas de talleres, las oficinas de las distintas áreas cardinales de la Tupac (Pueblos Originarios, Derechos Humanos e Inmigrantes, Jubilados, Deportes y Cultura, Agua y Luz, y Comunicación y Prensa), y un consultorio de atención médica y odontológica.

La oficina de Asesoría Jurídica cubre la necesidad de contención legal para muchas personas en temas vinculados con situaciones familiares, cuotas alimentarias, la violación de derechos por parte de empresas que gestionan servicios públicos privatizados, los abusos policiales, entre 
otras áreas problemáticas en las que brinda asistencia.

Desde el área de Derechos Humanos se programan recorridos por toda la provincia relevando necesidades e informando acerca de la posibilidad de acceso a derechos muchas veces desconocidos o inaccesibles por parte de habitantes de algunas comunidades provinciales. Se asesora y se acompaña la tramitación de pensiones, documentos de identidad, Asignación Universal por Hijo, entre otros. Por otro lado, se colabora con los trámites de radicación de inmigrantes, en algunos casos entre personas con dificultades con el idioma español.

En la oficina de Agua y Luz se viabilizan soluciones a familias mediante la entrega de medidores y la instalación del servicio en distintos asentamientos; además, se colabora con la intervención para la gestión individual frente a las empresas.

Desde el área de Jubilados se realizan tareas de prevención y concientización sobre los derechos a los que es posible acceder y se colabora con las necesidades puntuales de cada unx de lxs ancianxs que se acercan a la sede. Además, se organizan viajes, se dictan clases de yoga, y diferentes tipos de talleres y actividades destinados exclusivamente a la tercera edad.

El área de Salud ubicada en la sede central ofrece consultorios externos de medicina clínica, oftalmología, odontología, pediatría, traumatología, otorrinolaringología, ginecología, cardiología, kinesiología, fisioterapia y masoterapia, entre otras especialidades. También se encuentra el laboratorio de Análisis Clínicos, la sala de Rayos X y un tomógrafo computado. Por intermedio del Plan RemediAr, se posibilita el acceso a medicamentos de todo tipo provistos en la farmacia ubicada en el mismo edificio. En caso de tratarse de medicamentos con los que no se cuenta o que son de mayor complejidad, se gestiona la entrega de dinero para que lxs 
pacientes accedan a ellos en el ámbito privado. Así también, se hacen operativos de entrega de anteojos recetados y, periódicamente, se hace entrega de prótesis, audífonos y sillas de ruedas para quienes así lo requieran ${ }^{92}$.

La radio comunitaria FM Pachamama, al aire desde $2009^{93}$, se enmarca en la ampliación del espectro de producciones y contenidos a partir de la Ley de Servicios de Comunicación Audiovisual. La permanente búsqueda de ampliación de las herramientas comunicacionales demostrada por parte de la organización encuentra en la nueva ley una vía de consolidación de toma de la palabra que se fue fortaleciendo a lo largo de los años, sobre todo a partir de la producción de contenidos por parte de los distintos sectores y áreas al interior de la Tupac ${ }^{94}$.

Por su parte, los galpones recuperados de la estación de trenes son una experiencia de reciclado de los predios que pertenecían a la estación abandonada a partir de la desarticulación de la empresa pública nacional Ferrocarriles Argentinos entre 1991 y 1993. Se encuentran ubicados entre el casco céntrico de la ciudad, el puente Gral. Otero y la villa Punta Diamante, borde urbano del río Grande. El descacharro, desmalezamiento y puesta a punto para su utilización fueron de las primeras obras más destacadas en el perímetro céntrico de la ciudad por parte de lxs militantes de la organización. Se construyó allí un anfiteatro abierto en el que durante un

${ }^{92}$ A modo de muestra de las magnitudes de la atención médica brindada, de acuerdo con el responsable del área de Salud, el doctor Luis Luna, se realizaron durante el año 2014 más de noventa mil consultas en distintas especialidades en toda la provincia.

${ }^{93}$ Si bien comenzó a funcionar en el año 2009, recién a partir de abril de 2013 se oficializó su transmisión.

94 "En primer lugar mi adhesión total y absoluta al Proyecto de Ley de Radiodifusión, porque básicamente democratiza la información, hay algunos medios acá en Jujuy, medios escritos y otros televisivos para los cuales por ejemplo la organización Tupac Amaru no existe, es decir no sale en los medios como si no tuviera existencia pública o existencia real; eso también es una forma de tiranía de la información". (Raúl Noro, militante, esposo de Milagro Sala, en el Foro Participativo de Consulta Pública para el Proyecto de Ley de Servicios de Comunicación Audiovisual, mayo de 2009) 
largo período se ofrecían recitales semana a semana, un polideportivo con quinchos y pileta de natación, un galpón que funciona como SUM y un parque recreativo.

\section{4. Las cooperativas. Lxs obrerxs}

La coordinación de las diferentes etapas de la construcción, las fábricas, la seguridad barrial y las distintas áreas que hacen al acceso a condiciones de bienestar en el cantri, en la sede central (salud, educación, deportes, talleres, guarderías, panadería, etc.) y en los galpones se establece a partir de la conformación de cooperativas de trabajo. En este apartado haremos foco concreto en lo que corresponde al trabajo en aquellas dedicadas a la construcción y las obras.

Inicialmente podemos señalar que en las cooperativas de construcción de viviendas es habitual la disposición de grupos a partir de unx presidentx de cooperativas y alrededor de veinte obrerxs ${ }^{95}$. Al respecto, la consigna de la CTA "La nueva fábrica es el barrio" es una ilustración de lo que ocurre en el cantri. Podríamos afirmar que se ha cumplido cabalmente con tal ideal, dado que gran parte de las personas que viven en el barrio sostienen las distintas líneas de producción, tanto en un sentido económico, material y productivo, como de promoción comunitaria, voluntaria y de asistencia. En este sentido, el trabajo territorial llevado adelante por la Tupac retoma el accionar de muchas organizaciones, esto es, la producción de un hábitat a partir de la gestión de programas nacionales de políticas habitacionales. Y lo lleva adelante

\footnotetext{
${ }^{95}$ A su vez, existen en el barrio, encargadxs de obra, que cumplen con la función de responsables de las cooperativas del barrio, las distintas áreas que allí también cumplen funciones, la coordinación de la seguridad barrial e, inclusive, los términos de las convivencias.
} 
con una optimización de los recursos obtenidos, lo que genera una multiplicidad de eslabones que hacen de su producción un sistema que puede llegar a abarcar la satisfacción virtual de casi todas las necesidades de sus participantes.

Además de la labor propiamente hecha en el cantri, el camino de llegada que atraviesa parte de Alto Comedero también tuvo la intervención por parte del trabajo de la organización con la realización de cordones cuneta, desmalezamiento permanente de la plazoleta y la cancha ubicadas en la vía principal hacia el barrio. Este tipo de tareas se suma a otras como el desmalezamiento y descacharrado en terrenos baldíos, escuelas y colegios, el refuerzo de barreras de los ríos urbanos, y el mantenimiento de espacios públicos recreativos. Este trabajo fue gestionado ante y otorgado por la municipalidad de la capital provincial. En general se considera que los fondos de programas públicos por los que pelea la organización corresponden principalmente a los del Estado Nacional. Sin embargo, una buena parte de los recursos obtenidos para nuevas tareas de este tipo provienen de la gestión frente al Estado municipal y provincial.

En lo que respecta al proceso de trabajo en la construcción, como ya hemos mencionado, fue dentro del mismo grupo en donde se propiciaron las bases para la formación de lxs obrerxs que ingresaron a las cooperativas, ya que casi en su totalidad se trataba de personas sin experiencia previa en la construcción.

Me metí acá a la obra. Yo no sabía nada, noción de nada tenía acá, ni agarrar una simple pala. Después con el tiempo me han enseñado, así la gente de acá nomás. Señores de obra a hacer cosas, a hacer mezcla, a hacer hormigón, cómo levantar 
una pared. (Obrera, entrevista de noviembre de 2010).

Tantos años que estuve acá por lo menos sé hacer varias cosas que ni yo me imaginaba iba a poder hacer, revocar, machimbrar. En la casa de mi viejo teníamos que hacer y de acá nomás nos fuimos con el papá de mi hijo a trabajar. Te ayuda saliendo de acá, afuera vos podés trabajar. (...) Aprendés oficios, otros oficios. (...) La gente de acá aprendió muchas cosas en el trabajo pesado. Porque vos vas a buscar a una chica y le decís: ‘¿vos sabés?’ y no todos saben hacer lo que hacen acá. Acá te enseñan. Ponele vos vas a ir a tu casa y no vas a pagar un albañil para que te levante pared. Vos sola lo podes hacer. (Obrera, entrevista de diciembre de 2010).

Los oficios se aprenden a partir de la práctica y del trabajo colectivo. El aprendizaje social se da así en un proceso de aprehensión a partir de un entorno común en el que unx se instruye a partir de unx otrx, quien facilita el conocimiento. Los oficios, entonces, no se dan como una tarea meramente productiva, sino también con una inclinación pedagógica colectiva. Este espacio, entonces, fue concebido como laboral, pero también como político y de aprendizaje.

Así también se generan modos de escapar al automatismo envilecedor de la tarea fabril y obrera. Las tareas se diversifican y se van modificando las labores de muchos cooperativistas a lo largo de los meses y los años.

Ponele que te dice el encargado 'vos vas a obras', ahí ya vas a aprender de a poquito a poco, ya vas a aprender qué trabajos se hacen ahí. A veces ya corre un tiempo y te dicen: 'bueno, vaya a aquel taller para que aprenda a hacer las 
armaduras'. O de ahí pasa un tiempo largo y de ahí ya vas a aprender a otro lugar, por ejemplo, acá a soldar. Pero vas rotando, tenés que saber un poquito de todo, así que tanto mujeres como varones hacemos ese recorrido. (Obrera, presidenta de cooperativa de hierros, entrevista de septiembre de 2010).

El sistema de relaciones laborales a la vez supone un tiempo-espacio de integración social, de relación con otros, un momento en el que se van conformando vínculos sociales y de identificación. La apuesta por el lazo de socialidad emprendida se basa sobre todo en la comprensión colectiva de que estos espacios de producción están vinculados, además de a la satisfacción de las necesidades más próximas y urgentes individuales, a la concreción de materialidades para el bien colectivo. Esto los lleva a encontrarse con ese sentido de identificación con lo producido y con el fin de para quién se produce. El valor del trabajo se significa no solo por lo obtenido, sino también por las relaciones de producción en un ambiente de encuentro colectivo en favor del bienestar común:

Primero era una obligación. Lo sentía como obligación, pero después la rutina empezó a hacerse más constante y te das cuenta de que lo que yo hago no es para mí, lo que ellos hacen no es para ellos tampoco. Capaz que sí es para ellos, pero el que tiene la vivienda ya lo hace para otra persona. (...) Y lo que nos llevó a nosotros era eso. Construir, construir y construir para que todos tengan su vivienda, porque la necesidad es grande. (...) Por eso vimos esa necesidad que cada uno tuvo en la cabeza y esa necesidad fue lo que nos movió. De ahí fue cuando empecé a militar, a sentir que esto era una militancia y yo sé que mis hijos, mi hija me extrañarán, pero yo sé que tiene su casa. (Obrero, presidente de 
cooperativa, entrevista hecha en octubre de 2010)

Parte de la identificación con el movimiento se vincula, así, a un desplazamiento de esa significación negativa que suponía la desocupación, a partir de la producción en favor del bienestar común y en el sentimiento de pertenencia colectiva.

Sin embargo, es muy marcada en los relatos la presencia de la figura de la desgracia pasada y la experiencia trágica. La oportunidad revitalizadora no deja de verse atravesada por el dramatismo con el que se articula el sufrimiento experimentado y la posibilidad latente de su retorno. Es común el relato del sacrificio laboral, la extenuación de los cuerpos y la elevada exigencia por parte de la organización.

Por otro lado, más allá de la configuración de espacios de trabajo de tendencias favorables para el aprendizaje y la integración de sujetxs excluidxs de otras esferas laborales, se generan escenas habituales de marcada jerarquización en el vínculo entre obrerxs, presidentxs de cooperativas y encargadxs. La combinación entre relaciones laborales a modo de subordinación, la corriente noción de 'derecho de piso' que opera como parte del lenguaje ${ }^{96}$, la tendencia a actuar en favor de lo individual y el recelo, hacen visibles las lógicas de una doctrina encarnada en lxs sujetxs en la que custodiar lo propio es prioritario por sobre el favor colectivo ${ }^{97}$. Estas

96 "Viste cuando vos llegabas y decían: 'no, ella es nuevita, tiene que pagar derecho de piso'. Pero no era porque me discriminaban, era por decir nomás, pero en sí, nos hacían pagar derecho de piso, nos hacían laburar a full, nos sacaban el jugo. Acá en la Tupac. Pero después con el tiempo ya no, ya íbamos bien. En el trabajo ya de diez, ya no era tanta la exigencia del trabajo, sino que era igual a la de todos. Ya pagamos el derecho de piso así que trabajamos igual que los demás" (Obrera, entrevista hecha en octubre de 2010).

${ }^{97}$ La interpretación de estas lógicas es afín a la que elabora Rivera Cusicanqui (Colectivo Simbiosis, Colectivo Situaciones, 2011) como parte de las prácticas en los talleres textiles del conurbano bonaerense, haciendo atravesar esta praxis con las fibras del colonialismo interno, la explotación y la desarticulación de las históricas redes comunitarias andinas. 
actitudes hacen parte de un repertorio de vilezas experimentadas en carne propia, tanto a raíz de la herencia de dominación colonial -desde los estratos de la servidumbre- y el histórico yugo despótico en plantaciones agrícolas, como de haber incorporado los residuos más trágicos del discurso neoliberal -la explotación y el ultraje- y dictatorial -el "no te metas". Parece así por momentos que la recomposición de lo material y lo económico es aún más sencilla que la recomposición del lazo social.

Esta crudeza del trabajo obrero, la imposibilidad de transmitir lo que se ve entre los cuerpos de lxs obrerxs, tal nivel de sacrificio y extenuación, se experimenta por dos vías, o al menos, dos acepciones comunes respecto de lo que significa el empleo del cuerpo para el trabajo articulado en palabras: Entre quienes asimilan la posibilidad del trabajo como una experiencia que 'soportan' por la obtención de dinero y el 'miedo' a la pérdida; y entre aquellxs que llegan a elaborarlo con un fin más allá del personal, quienes someten a una reflexión social, la tarea individual. Es decir, que aquello que se hace tiene un fin más allá del interés propio y próximo. Estas vertientes expresivas se dan de manera confluyente y contradictoria inclusive en relatos de una misma persona.

Sin dejar de subrayar las tensiones del trato en términos de subordinación y el individualismo residual mencionado, el engranaje subjetivo obrero se articula en un cruce entre lo agobiante de la tarea, el temor frente al horizonte subjetivo siempre presente de las experiencias de privación y carencias, la vitalidad de las nuevas experiencias de acceso a la posesión y al consumo, y la auto-identificación como parte de un proyecto que encarna en la noción de la moral del trabajo las bases para el bien común. 


\section{5. Tupaqueras}

Un número significativo de lxs obrerxs fueron y son mujeres, gran parte de las cuales no habían tenido hasta el ingreso a la Tupac experiencia previa en albañilería, herrería y construcción. Los oficios aprendidos son variados y comprenden tareas tales como levantar paredes, hacer el revoque grueso y el revoque fino, el preparado de las mezclas de cemento, el zarandeo de arena, la instalación de cerámicos y cielorrasos de machimbre, la realización de instalaciones eléctricas, de gas y de cañerías, el armado de los estribos y armaduras de hierro para las casas, la construcción de los bloques de cemento, el armado de la carpintería metálica, y la pintura de las viviendas, entre otras tareas. Tal como hemos planteado, fue dentro del mismo grupo en donde se propiciaron las bases para la formación de la gran mayoría de lxs obrerxs.

En el caso de las obras, la mayoría son mujeres. Si vos vas a la parte de hierros, todo lo que es estructura de hierros, son todas mujeres las que realizan. La sede está hecha por mujeres. Quien cavó para la pileta climatizada fue una mujer que manejó esa máquina. Que nos extrañó a todos ver semejante monstruo con una mujer manejando, imaginate para nosotros el orgullo, viste. Los muchachos se quedaban con la boca abierta, pero es lindo porque la mujer está abarcando un lugar hoy en día parejo. Y bueno, está saliendo a luchar. Ya no te quedás en casa

y te quedás con el conformismo. Yo creo que ahora la mujer tiene muchas posibilidades. (Obrera, entrevista de octubre de 2010)

Entre las mujeres, un gran número de las incluidas en los proyectos de construcción de 
viviendas están embarazadas ${ }^{98}$, o son madres solteras, analfabetas, ex presidiarias, mujeres con problemas de salud (sobrepeso, por ejemplo) y en un rango de edad que no entra dentro de los requisitos que se exigen habitualmente en el universo laboral privado. Por otro lado, es relevante señalar la participación de las mujeres ocupando un rol, no solo como constructoras u obreras, sino también como presidentas de cooperativas y encargadas de obras, cargos jerárquicos pocas veces alcanzados por mujeres en el ámbito laboral, en la acción sindical, y en el trabajo popular y comunitario. Esto, sin embargo, es solo una de las apreciaciones iniciales acerca de las incidencias de los vínculos atravesados por el género que se señalarán en la tesis.

A esta altura es importante establecer que hablar de mujeres implica un ejercicio de complejización de la categoría más allá del establecimiento de la habitual presunción de la construcción cultural sobre una condición biológica. Esta acepción común acerca de la diferencia de género esquiva un debate profundo acerca de lo que supone constituir a todas las inequidades a partir de una raíz supuestamente natural. Si bien el análisis basado en la distinción binaria (varón/mujer) permite hacer visibles condicionamientos y desigualdades históricas a modo de puntos de partida analíticos, este tipo de acepciones sobre la constitución del colectivo 'mujeres' no puede agotarse en una elaboración que las construya solo en condición de diferencia respecto de un "uno'99. En este sentido, el potencial de la categoría analítica mujeres se fortalece al concebirla más allá del sistema varón/mujer, que en definitiva responde a percepciones hegemónicas heterocentradas, patriarcales y modernas occidentales. Escapar de la

${ }^{98}$ En los casos en los que se mantiene en la sección de obras a las mujeres embarazadas, se las reasigna al obrador en donde trabajan haciendo inventarios de herramientas y materiales. Como ya hemos mencionado, parte de las mujeres que se encargan del estímulo y cuidado de lxs niñxs en las guarderías son obreras embarazadas reasignadas.

${ }^{99}$ La cuestión no es escapar del binarismo, ni negarlo, claro está. El alerta sobre ellos persiste en la pregunta acerca de por qué reaparecen permanentemente los binarios (Grossberg, 2006). 
universalidad del concepto, tal como ha transcurrido en los debates durante las últimas décadas al interior del feminismo, nos permite distinguir las situaciones que atraviesan a todas las mujeres invisibilizadas en la caracterización hegemónica de la mujer y de su rol social. Para ello, el feminismo poscolonial, el feminismo lesbiano, el feminismo negro y el postfeminismo han servido para iluminar la diversidad de opresiones que se intersectan con el género al pensar la etnia, la clase, la raza, la sexualidad, la identidad de género, la nacionalidad y la edad como factores que inscriben otro tipo de experiencias sobre los cuerpos más allá de la caracterización hegemónica de la mujer (Paredes y Galindo, 1992; Mujeres creando, 2005; Rich, 1980; Wittig, 1992; Curiel, 2011; Segato, 2007; Anzaldúa, 1987; Lorde, 1984; bell hooks, 1981; Haraway, 1991; Spivak, 2011; Butler, 2008, 2007, 2005) ${ }^{100}$. Esta explicitación acerca de las condiciones de heterogeneidad del colectivo abre la posibilidad a pensar otro tipo de situaciones, tanto en lo que refiere a otras subordinaciones, como a otras acciones agentes.

Construir esta conceptualización acerca del colectivo de mujeres permite dejar abierta la veta del análisis desde una perspectiva de género a lo largo de toda la tesis como eje articulador, atendiendo a su productividad epistemológica en tanto que lente que atraviesa las experiencias, las identificaciones y las demás materialidades en la reproducción empírica analizada; un lente que modifica las prioridades analíticas. Un ejemplo de ello refiere a la especificidad de pensar

100 "Estas teorías del posicionamiento social de las mujeres sientan las bases y organizan la teoría feminista 'genérica', en la que conceptos como 'la casa de la diferencia' (Lorde), 'conciencia opositiva' (Sandoval), 'mujerismo' (Walker), 'desplazamiento desde el centro a los márgenes' (Spivak), 'feminismo del Tercer Mundo' (Moraga y Smith), 'el mundo zurdo' (Anzaldúa y Moraga), 'la mestiza' (Andalzúa), 'capitalismo patriarcal racialmente estructurado' (Bhavnani y Coulson, 1986) y 'el otro inadecuad' (Trinh, 1986-7, 1989) estructuran el campo del discurso feminista conforme éste descodifica lo que suele entenderse por 'mujer' tanto dentro como fuera del 'feminismo'. Asimismo han surgido metáforas complejamente relacionadas en la escritura feminista de las 'mujeres blancas': 'clases político-sexuales' (Sofoulis, 1987), 'cyborg' (Haraway, 1985); y el sujeto mujer del feminismo (de Lauretis, 1987)" (Haraway, 1991: 243244). 
a las obreras y militantes, y por qué aún hoy es importante señalar que las mujeres emprendan y ocupen un rol destacado en cantidad y en jerarquías en lo que respecta al trabajo y a la militancia entre los sectores populares. Al interior de esta pregunta, considerar qué particularidades y tensiones guarda la Tupac en los procesos inclusivos de las mujeres.

Es importante señalarlas no solo porque en muchas aproximaciones analíticas sobre sectores pobres o empobrecidos suele hacerse foco en la condición de clase por sobre los demás factores de vulneración, sino porque cuando efectivamente se considera el elemento de género para pensar la condición de las mujeres pobres, se lo hace caracterizándolas como colectivo en función de un rol sociocultural dominante establecido: como vehículos de las necesidades ajenas, como un sector históricamente relegado a las tareas domésticas, como un sector cuya participación política y en el ámbito público en términos de militancia ha sido invisibilizado, o como colectivo homogéneo con el potencial para establecer una "agenda de temas de mujeres" (Di Marco, 2011; Partenio, 2008), soslayando dichas demandas al perfil hegemónico antes construido.

Todos estos factores son señalados como parte de un tema prolífica y fructíferamente estudiado, habiendo investigaciones antecedentes que sostienen y confirman estas premisas, las cuales sostenemos como parte de nuestras herramientas analíticas (Andújar, 2005; Di Marco, 2011; Partenio, 2008; Causa y Ojam 2008; Svampa y Pereyra, 2003 [cap. 4]). Además de las características enunciadas se reconoce una sumatoria de elementos que hace a la vulneración de las posibilidades en la situación de las mujeres obreras ${ }^{101}$.

101 El panorama armado acerca de los perfiles de personas que trabajaban en las cooperativas del cantri en el año 2010 muestra que: dos de cada tres mujeres no había concluido sus estudios secundarios; el promedio de varones que habían terminado el secundario casi doblaba al de las mujeres que así lo habían 
Como dato inicial, respecto de los trayectos previos de las militantes incorporadas, se confirma lo reconocido por la literatura en torno de las mujeres y las clases populares. Así es reconocible el modo en que opera en sus trayectorias un proceso de "feminización de la pobreza". Con esto nos referimos a la mayor posibilidad de las mujeres de ser pobres, debido a la discriminación laboral y a una menor tasa de empleo ${ }^{102}$; a los menores ingresos alcanzados por jornadas más largas; lo que también lleva a la mayor posibilidad de que un hogar sostenido por una mujer tenga más posibilidades de caer en la pobreza ${ }^{103}$; la invisibilización y la falta de retribución por el trabajo doméstico, de reproducción familiar y de cuidado ${ }^{104}$; la falta de recompensa al trabajo comunitario; que además deviene en pobreza de tiempo ${ }^{105}$ en la combinación de estas tareas y

hecho (60\% versus 33\%); y aun siendo el doble las mujeres en la muestra, era igual el número de varones que de mujeres que habían accedido o accedían a una enseñanza superior. Entre las quince jóvenes menores a veintinueve años, diez no habían concluido el secundario. El dato más relevante es que en todos los casos se trataba de jóvenes con hijxs o embarazadas. La maternidad adolescente incide decisivamente sobre las oportunidades y condicionamientos en su formación y futuras perspectivas de trabajo (Silveira y Camusso Pintos, 2010). Y, de hecho, en seis de los diez casos en los que las jóvenes decidieron interrumpir sus estudios fue debido a la maternidad adolescente. Por otro lado, los empleos previos a los que pudieron acceder algunas de las mujeres eran de inserción endeble, esporádicos, ocasionales, y la precariedad era un rasgo dominante en sus experiencias laborales.

${ }^{102} \mathrm{Si}$ bien las mujeres representan la mitad de la población, su tasa de empleo es más baja que la de los varones (en Argentina 43,1\% para las mujeres y 67,8\% para los varones, Encuesta Permanente de Hogares [EPH]. 3er trimestre de 2013).

${ }^{103} \mathrm{Al}$ respecto de la conformación de hogares en el cantri, sobre un muestreo realizado sobre 35 hogares, 20 de los 35 eran de jefatura de mujeres solteras, viudas o separadas con hijos. Así, los hogares monoparentales femeninos constituían la morfología familiar más repetida en las viviendas. Gran parte de las mujeres vive con unx solx hijx. Estudios que consideran los índices de pobreza en un hogar con jefatura femenina relevan el modo en que inciden el nivel de ingresos total, como la cantidad de habitantes (su edad y su sexo) por vivienda (Geldstein, 1997; Rotondi, 2000). Ya el hecho de que en el muestreo se encuentren solo hogares monoparentales femeninos da una pauta acerca de la relativa imposibilidad de autonomía y acceso a la vivienda por parte de las mujeres respecto de los varones.

${ }^{104}$ En entrevistas en profundidad entre diez mujeres menores a los 30 años en concubinato dentro del cantri, ocho de ellas asumían realizar todas las tareas domésticas no remuneradas en sus viviendas. De acuerdo con los indicadores relevados por el Ministerio de Trabajo, Empleo y Seguridad Social en 2013 (en un cruce entre la EPH y el Boletín de género de dicho ministerio) las mujeres dedicaban en promedio 6,4 horas del día a tareas domésticas no remuneradas (quehaceres domésticos, apoyo escolar y trabajo de cuidado) frente a un promedio de 3,4 horas por parte de los varones.

${ }^{105}$ Rotondi (2000) asegura que la mujer tiende a acceder a empleos cerca de su casa debido a la pobreza de tiempo, dado que dispondría de menor tiempo por la cantidad de tareas y responsabilidades asumidas por coordinar a diario. La reducción del radio de acción cotidiana (en el empleo, el trabajo comunitario y la 
de otras responsabilidades como tiempo de empleo remunerado, y tiempo de domesticidades y cuidado familiar; así como las mayores dificultades de acceso a una cobertura básica e informada en la salud.

Señalamos el factor de relevancia de un fenómeno como la feminización de la pobreza, no para establecer una asociación mecánica entre mujeres y pobreza, o para ubicarlas en un rol fijado como víctimas, sino para instaurar de manera más cabal el modo en el que se estructuran las condiciones de vulnerabilidad en las relaciones de género, con la dimensión de la pobreza como uno de sus factores de incidencia (Chant, 2003).

Cada uno de estos puntos son claves para considerar tanto el modo en el que las mujeres pobres se han incorporado al movimiento de la Tupac, como las dificultades con las que se encuentran en la reproducción cotidiana de sus vidas. Pero, más allá de esto sostenemos que hay factores que se hacen visibles recién de manera directa al recorrer las obras, las convivencias y las dinámicas experimentadas a partir de la inserción en la Tupac.

Queremos destacar tres elementos que nos parecen significativos en la incorporación de las masas del colectivo de mujeres a la organización militante y a las tareas de producción y construcción:

- Primeramente, la genuina consideración por parte de las mujeres de que no existe espacio para ellas por fuera de la Tupac. El peso de esta expresión no debe tomarse a la ligera. Hablamos de que no solo se trata de que no consigan ámbitos en los cuales desenvolverse

recreación) también es un factor a tener en cuenta. Así se genera un cruce de empobrecimiento temporal y espacial en la vida de las mujeres. 
en un empleo de condiciones dignas, de respeto y en el que se propicie su participación ${ }^{106}$ (con el impulso de redes de cuidado, desarrollo y alimentación infantil, escuelas y centros de salud cercanos); sino, sobre todo, la imposibilidad de imaginar una vivienda como aquella a la que acceden mediante las obras construidas ${ }^{107}$. Cuando decimos que el espacio tiene efectos sobre la vida de las personas también nos referimos a esto, a la magnitud que supone sentirse materialmente restringida en las posibilidades de habitar otro espacio que no sea el que se encuentra generado, en este caso en la organización.

- $\quad$ En segunda instancia, la veta de reconocimiento de la posibilidad de empoderamiento a partir de encontrarse frente a la figura de una mujer líder con la que se identifican. La atribución de una serie de características a Milagro Sala se encuentra en muchos casos imbuida de elementos positivos que son próximos a sus propias construcciones de sí mismas. Esta caracterización sobre la que se asienta parte de la identificación se elabora sobre la base de afectividades que cohabitan y no necesariamente son coherentes entre sí. En muchos casos refiere a la perseverancia para alcanzar algo 'a pesar' de ser pobre, por

106 “O sea, es más fácil para él [mi marido] conseguir trabajo afuera que para mí. (...) Porque vos salís de acá y a una mujer no la toman en varios lugares para trabajar como se trabaja acá. Y si te toman no creo que te paguen lo que a mí me pagan acá." (Obrera, entrevista de octubre de 2010).

"La parte que siempre se ve de las mujeres es que siempre viene acá o cayó acá en la organización por un tema de que si no ha sido golpeada, ha sido maltratada por alguna persona, o sometida a algún laburo en el que capaz que no le pagaban bien. La mayoría que llegó acá es porque tuvo necesidades de trabajo y tener bien a sus hijos." (Presidente de cooperativa, entrevista de octubre de 2010).

107 "La experiencia que yo tuve fue ser muchacha o niñera. Y la verdad que al compararlo con esto, me quedo con esto. Aparte de tener mi sueldo, mi casa, que vos sabes que si vas al plan FONAVI [Fondo Nacional de Vivienda] tenés que tener plata, ser de cuña o ser hermosa y pasar por las manos de ellos. Y no somos hermosos ni tampoco nada de eso. Acá lo único que a nosotros nos pidieron es organizarnos, trabajar, meterle adelante y cuidarnos entre nosotros." (Obrera, entrevista de octubre de 2010). 
no depender de una figura masculina ${ }^{108}$, por la fortaleza ${ }^{109}$, la dureza, o inclusive por una imagen construida en torno del maternalismo en la figura de Sala ${ }^{110}$.

- $\quad$ Un último punto que queremos señalar tiene que ver con el modo en el que la Tupac ha devenido en ámbito de encuentro de muchas mujeres lesbianas y trans, en tanto opera no sólo como lugar de oferta de empleo y trabajo relativamente estable -en un sector altamente intersectado por la vulneración a partir de la clase, el género, la sexualidad y la elección afectiva-, sino que además se elabora como espacio alterado y distanciado de las lógicas heteronormativas más violentas, desde los espacios institucionales generados para la promoción del respeto y la valoración ${ }^{111}$, hasta el desarrollo afectivo público más cotidiano entre militantes y obreras ${ }^{112}$.

108 “Acá por lo menos la flaca ha hecho cosas, sin ser diputada, sin ser concejal, sin ser un hombre delante de Milagro, ella lo hizo con lo poco que tenía" (Obrera, entrevista de octubre de 2013).

109 "Si Milagro no sería una mujer tan emprendedora y tan fuerte, que yo la admiro mucho, te digo que no tendríamos lo que tenemos" (Militante, entrevista de octubre de 2010).

110 "Por eso te digo que me indigna a mí que si hay alguien, algunos que hablen mal de nuestra mamita, porque yo la considero mi mamita a la Milagro (...). Porque ella, y acá sabemos todos, que de lunes a lunes está de aquí para allá para ver que saca para los que menos tiene. Anda trabajando, mirando en las provincias. Viendo por el que menos tiene para darle una solución" (Obrera, entrevista de septiembre de 2010).

111 “Ahora ya salí y todos nos miraban, que salíamos de la mano y más que acá es la igualdad, igual la gente nos miraba mal, porque era muy visible lo que se estaba viendo. Y después la flaca [Milagro] dijo que no había discriminación para nadie. (...) Hasta castigó también a varios" (Militante, entrevista de noviembre de 2010).

112 "Y después yo veía chicas que coqueteaban entre chicas y yo decía 'qué raro, chica contra chica'. Me quedaba shockeada, no podía creer qué pasó. O chango contra chango. Y acá en la Tupac se ve eso. Chu qué raro" (Militante, entrevista de octubre de 2010). 


\section{6. El cantri}

Quizá lo más duro era tener un techo; pero a la larga se conseguía, bueno o malo. Y desde la vivienda, primaria quizá, pero urbana al fin, parecía que se tenía el derecho a reclamar todos los beneficios de la vida urbana, aquellos de que gozaba el que ya estaba establecido e integrado.

José Luis Romero. Latinoamérica, las ciudades y las ideas

El cantri, como anuncia el cartel de bienvenida al barrio ubicado dentro de Alto Comedero, es una parodia con tintes de real en relación de comparación con la estructura y funcionalidad de este barrio con otras urbanizaciones de este tipo. Para empezar, tiene de parodia una razón de clase fundamental. A él se mudan, no aquellos ciudadanos que pueden económicamente y optan culturalmente por 'resguardarse' de la ciudad como un todo en reservas urbanas en las que se vinculan con pares de clase; sino que, como parte de un proyecto de urgencia habitacional, se construyeron -y construyen- miles de viviendas para que se muden ahí decenas de miles de sujetxs que carecían de condiciones mínimas habitacionales de forma previa, tanto militantes y obrerxs de la organización, como personas 'ajenas' al movimiento.

Tiene de country real lo funcional de su territorio. En los límites barriales, virtualmente se presenta todo lo necesario para la reproducción cotidiana de lxs sujetxs. En él se vive, se come, se trabaja, se va a la escuela, se compra, se duerme, se realizan actividades de esparcimiento y se recrea, se hace deporte, etc. Y así lo significan lxs vecinxs. 
Se fueron construyendo viviendas, en las cuales hoy en día nosotros somos parte de esa ciudad, porque ya es una ciudad. (...) Te digo que no tendríamos lo que tenemos. Hoy en día, si vos conocés el barrio, es una ciudad. (Militante, entrevista de septiembre de 2010)

Sí, cuando ellas [mis hijas] se enferman las traigo acá [al CIC]. Además usan la pileta, usan el parque. O sea, todas sus actividades están dentro de este lugar. De acá no salen salvo que para ir al colegio nomás. Pero después todo está acá adentro. No tienen necesidad de salir del barrio. (...) Y yo trabajo acá, vengo acá, tengo a mis hijas acá. Y bueno, salvo ir a pagar las cuentas y hacer cosas afuera o ir al centro, viste, y nada más. Después todo es acá adentro. (Vecina, entrevista de septiembre de 2010)

La funcionalidad que presenta el territorio parece plantear todo para que la experiencia cotidiana se escenifique como no demasiado distante de lo que suponen otras urbanizaciones privadas. Pero ese es el punto para un giro de tuerca fundamental para la reflexión. Los countries tienen como objetivo reformular la vida pública de los sujetos. Se privatiza aquello que era público, la vida con los otros, más cercanos o más lejanos. Tiene la intención de fracturar el vínculo, de establecer limitaciones extremas a la privacidad del individuo.

Sin embargo, este barrio, el cantri, tiene su génesis en la comunidad, en la labor comunitaria y en la relación estrecha de todos los ámbitos cotidianos en la vida de lxs sujetxs. Quienes viven en el barrio trabajan, en su mayoría, construyendo nuevas viviendas para más familias ${ }^{113}$; cientos

\footnotetext{
${ }^{113}$ En la gran mayoría de las familias, lxs adultxs que trabajan, lo hacen de una u otra manera en relación con
} 
de viviendas se prestan a diario al trabajo por parte de lxs cooperativistas en copas de leche para lxs niñxs del barrio; un número importante de estxs niñxs comen día a día en el comedor del CIC; la educación, la salud, los talleres recreativos y formativos, las áreas de esparcimiento, son todas de acceso público y gratuito, y de gestión comunitaria.

Este trastrocamiento fundamental de aquello que implicaría una urbanización cerrada, la fragmentación socio-económico-espacial y los miramientos acerca de lo privado como propio e individual (o a lo sumo familiar), resquebrajaría de plano escisiones espaciales pre-asumidas. No sólo con respecto a esos espacios sociales que responden a las características tipológicas que han presentado en las últimas décadas estas nuevas urbanizaciones, sino además en relación al histórico ánimo moderno occidental de dividir y cercenar los diferentes ámbitos de reproducción de la vida. Sin embargo, es necesario tomar los recaudos de lectura para que, más allá de estos preconceptos acerca del espacio, se incorpore esta experiencia barrial a una historicidad de los sectores populares por "desesferizar" los espacios en favor de una mayor productividad beneficiosa común (Carman, 2006).

Las concepciones previas acerca de las urbanizaciones cerradas, tanto las externas que la interpretan a partir de sus lógicas privatizantes, como la de lxs sujetxs mismxs que en el barrio habitan y gestionan el territorio, significándolo en buena medida como si de un country se tratara, deben ser detenidamente consideradas al reconocer en las observaciones los bordes de lo paródico, las naturalizaciones acerca de lo privado, el modo en el que se configuran imaginarios acerca de la seguridad y la cierta necesidad de una fuerte presencia de resguardo

las obras de construcción de viviendas. En más del 80\% de las familias del muestreo llevado a cabo al menos un integrante trabaja de esta manera. 
como parte de un mecanismo de defensa en el empoderamiento de los sectores populares.

Volviendo a las bases comunitarias de ejercicio barrial, asumimos que al delegar acciones en el trabajo comunitario en el barrio, tanto la Tupac como cualquier tipo de organización colectiva de este tipo, "adquieren un rol gravitante en la vida cotidiana de las familias de sectores populares” (Mezzini, Labecky y Bráncoli, 2010: 55), tanto por las necesidades que satisfacen de forma comunal, como por el trabajo necesario para llevarlos adelante. Como parte de las cotidianidades de algunxs, el trabajo comunitario implica destinar no solo horas de días, sino también modificar los usos de los espacios, dado que tanto las copas de leche, como los roperos comunitarios funcionan en las viviendas de las familias. Por unas horas del día la vivienda deja de cumplir con la función de espacio propio para transformarse en espacio de producción en función de otrxs. Decenas de personas se turnan durante la semana para transitar por la vivienda del/x encargadx de organizar la copa de leche en su casa para preparar desayunos o meriendas para lxs niñxs del barrio. Así, el 'espacio de lo íntimo' se convierte en el 'espacio de lo colectivo"114. "A partir de esta dinámica, se generan vínculos que hacen permeable la frontera de la familia y su vida doméstica como espacio privado (...). Es decir, la situación de las familias se torna cada vez menos privada y más (pública) comunitaria" (Lavandera y Maglioni, 2010: 134). Asimismo, el mundo laboral asume todo un universo de convivencias que se extienden más allá de las fronteras del lugar del empleo: se convive en el barrio con las mismas personas

${ }^{114} \mathrm{Si}$ bien estas prácticas complejizan las nociones de lo público y lo privado, históricamente el barrio aparece como una noción dinámica. Mayol (2000) afirma que en el barrio el límite entre lo público y lo privado constituye una separación que más que separar, une en la práctica a ambos elementos. Aquí ambas categorías no son exógenas, sino coexistentes, interdependientes, ya que en el barrio, una no significa sin la otra. Pueden reconocerse territorios no del todo delimitados, sino "espacios liminares" (Carman, 2006, p. 188). "Privatización progresiva del espacio público" (De Certeau, Giard y Mayol, 2000, p. 42), la apropiación de ese espacio funciona en ambas direcciones: como continuidad entre aquello que se percibe como más íntimo (la vivienda) y aquello que es más desconocido (la ciudad en su conjunto). 
con las que se convive en el trabajo. Se van dibujando de esta manera otras lógicas de relación que rigen los vínculos laborales, vecinales y comunitarios dado que las acciones que llevan adelante en el barrio aparecen en las representaciones de muchos integrantes como abarcadoras de casi la totalidad cotidiana. Las relaciones en los distintos ámbitos se condicionan así porque los vínculos entre compañerxs de trabajo son, en otros momentos, vínculos tanto con lxs mismxs vecinxs, compañerxs militantes, colaboradorxs en tareas comunitarias, encargadxs de la seguridad barrial como con familiares. En este sentido es ineludible considerar las tensiones que se generan en las relaciones por las jerarquías, las responsabilidades compartidas y los vínculos filiales; todos ellos indefectiblemente conectados y entretejidos entre las políticas de la organización, las relaciones barriales y las dinámicas intrafamiliares.

Así también, y en lo que refiere a la injerencia de la Tupac como estructuradora de la vida en el barrio, es importante mencionar a qué remite la presencia de agentes de articulación, control y vigilancia. Estas personas intervienen tanto en el sector productivo y comunitario, como en las formas en las que se vive y se convive en los hogares y en los espacios de esparcimiento común.

\section{7. El country. De la apetencia por la seguridad}

Parte importante de la vida en un country transcurre frente a los imaginarios acerca de la seguridad que implica la limitación territorial. Lo más próximo conocido, la fisonomía vallada, la frontera bien delimitada de lo externo, todo juega a favor de las sensaciones placenteras que provocan mecanismos de seguridad diversos, pero que tienen el fin de hacer materiales y 
visibles, presentes los elementos del resguardo de lo ajeno y desconocido (Svampa, 2001).

En este sentido, el cantri también brinda a sus habitantes mecanismos de protección barrial: las vallas en la entrada al barrio, cerradas y vigiladas en las noches, lxs serenxs que recorren todas sus calles las 24 horas del día, lxs encargadxs de obras -quienes personalmente se comprometen a lidiar con situaciones y conflictos, tanto en el ámbito laboral, como en el familiar y doméstico.

¿Qué trabajos hacen los serenos?

Mayormente vigilancia de distintos puestos de importancia. Mayormente las fábricas, salud. Mayormente el recorrido del barrio. (...) A la noche los ves. Yo creo que es cuando más importancia le dan. Mayormente la gente también tiene mucha familia. Como son gente nueva tienen mucha familia afuera. La gente va a visitar a su familia y realmente se ve necesario que haya serenos.

¿Vos consideras que la vida en el barrio cómo es?

Tranquila. Por ahora tranquila. Espero que siga así. (...) Yo antes vivía en Alto Comedero, en la casa de mi mamá.

¿Y crees que es distinta la vida acá que en otros lados?

Sí. De mi forma de ver, a mí me gusta mucho el barrio. Me siento tranquilo acá en el barrio. Yo creo que en otros lados ya son siempre los mismos problemas. Entonces uno se cansa de ver todo eso. Y acá te dan la posibilidad de que el barrio sea tranquilo. Tenés serenos de seguridad propia. Muchos menos problemas que en otro lado. (Vecino, noviembre de 2010)

No es casual el modo en el que se asocian las situaciones de inseguridad con los barrios 
colindantes, territorios populares concebidos desde los discursos de la seguridad como caldos de cultivo del delito. El temor social no es un elemento que atañe solo a los agentes territorialmente externos, sino que se percibe como situación peligrosa entre próximxs. Y en este sentido, la seguridad se percibe como una problemática que afecta directamente el patrimonio y la tranquilidad personales. Tal como plantea Rodríguez Alzueta (2014) en el miedo al delito opera sobre todo el resentimiento social, como respuesta de una sociedad descolectivizada y reindividualizada frente al malestar social generalizado que se experimenta desde hace décadas con el Estado neoliberal y penal o policial (Wacquant, 1999). Es difícil ante este panorama intentar dibujar lazos de solidaridad y comunidad, sobre todo cuando se sostiene de manera tan presente la inhospitalidad y la hostilidad como lógica social para el vínculo con unx otrx ${ }^{115}$.

Y más allá del castigo y la punición, lo que se focaliza es la prevención del disturbio y el delito. El control de las sensaciones de seguridad se basa en la presencia ubicua de elementos de vigilancia pertenecientes a la organización; de la relativa novedad vecinal entre los nuevos vecinos $^{116}$; y la contraposición entre lo experimentado previamente en otros sectores, frente a la tranquilidad que implican, no sólo la presencia de la seguridad, sino la pertenencia casi unánime a la organización social, lo que, en sus interpretaciones, implicaría una correspondencia de códigos comunes para la convivencia:

Nosotros acá la casita la dejamos así. Hay veces, vecinos que van dejan sin llave

${ }^{115}$ Utilizamos la noción de hospitalidad en el sentido que le dan Derridá y Dufourmantelle (2000) en tanto que no puede haber hospitalidad o justicia sino ahí donde, de manera inmensurable se tiene en cuenta la alteridad del otro, como alteridad absoluta, inesperada e irreductible.

116 Durante el período de campo durante 2010, entre los relatos conseguidos, el período de tiempo que llevaban viviendo en el barrio iba de entre los tres meses hasta los cinco años, como máximo. 
y vuelven y tienen que estar así. Para eso somos compañeros y estamos acá viviendo. Y no nos tenemos que robar acá entre nosotros. Quizás a veces si roban, son gente de afuera, que entran por la cuarta [etapa], que hay casas que están vacías. Entran por ahí y de ahí entran a robar. (Vecina, entrevista de noviembre de 2010)

La reiterada presencia hace verosímiles los discursos acerca del barrio como una entidad diferente, ajena a lo que sucede entre aquello que lo circunda. Sin embargo, esta suerte de presencia institucional del movimiento social hace de las experiencias de los sujetos un entramado complejo en vinculación con aquello que se representa como privado y cotidiano y aquello público y comunitario, barrial y de injerencia organizacional.

¿Qué tal es vivir al lado de la oficina de los encargados?

Un martirio. No me gusta. No los puedo putear a mis hijos a veces (...) No, no se puede. No me gusta. Mucho vigilante. Me siento vigilada, en serio, re vigilada. ¿Por qué?

Porque están todos los encargados, nunca me puedo hacer una jugada. Nunca me pude escapar del trabajo y venir acá, que lo parió. (...) Puta, por vivir al lado de la oficina. (...) Bueno, pero tiene sus ventajas y sus desventajas. A veces cuando hacen el día del niño todos los días mis hijos están ahí: 'qué es eso'. Y ya se vienen con algo. Bueno, pero ya los conozco a todos, cuando necesito mercadería le digo: ‘che ¿me podes dar mercadería, un bolsón?’. Y ahí nomás me da, no me queda lejos, ahí nomás. Pero sí es medio fule che. Me siento vigilada. Bah pero mientras no me rompan las bolas, igual. Eso es lo que me caga, que no puedo hacer la 
jugada. Ni venir un día a hacer una festichola.

¿Hay sereno en la oficina todo el día?

Sí, a la noche queda un sereno en la oficina, creo che. Creo yo, porque a la noche voy al fondo y se siente un ruido: 'debe ser el sereno' digo. Capaz que es el fantasma Tupac. (...) En la parte en la que estoy yo es tranquila. Mucho chusmerío, sí. Vos salís y ya aquel comué y aquel y aquel. Yo no salgo, estoy metida en la casa. (Vecina, noviembre de 2010)

El reconocimiento en los relatos de un cercenamiento de las privacidades y una reducción de los bordes de lo propio (de lo personal) se presenta como evidente disrupción acerca de las concepciones previas de las distintas escenas cotidianas. Se rehúye a disponer de todos los espacios como vidriera común. La lógica espacial que se construye e intenta reproducirse en el cantri tensiona el proceder que sostiene reminiscencias individualistas de lo que supone la reproducción cotidiana. En términos espaciales, no se dispone de pertenencias individuales; se antepone el bienestar colectivo y el orden funcional a las disposiciones organizativas.

$\mathrm{Al}$ respecto, vamos a señalar dos puntos que se destacaron como parte de los discursos más habituales respecto del cantri:

- Primeramente, un mito histórico acerca del barrio. La noción de que unx no puede ingresar sin autorización de la organización, y que la vigilancia privada restringe la libre circulación por el barrio y no permite el ingreso de fuerzas policiales externas. Desde que hemos iniciado la tarea de campo nos hemos encontrado con este tipo de discursos entre la población local que no pertenece a la Tupac.

- $\quad$ Por otro lado, que en tanto no se entregan inmediatamente los títulos de propiedad de las 
viviendas, lxs habitantes del barrio se sostienen 'cautivxs' de la organización ${ }^{117}$. O, en una versión discursiva cercana, que la Tupac Amaru -y Milagro Sala- pueden proceder a quitar la vivienda entre vecinxs que no adhieran a los rumbos políticos del movimiento. El porqué de esta captura difamatoria tenemos que rastrearla por diversas vías con el claro alerta de la complejidad de trazar una lectura de crítica cultural sobre un proceso histórico en marcha. El cantri es sobre todo una promesa para el beneficio colectivo e individual popular. Esto se representa de manera ubicua en modalidades diferentes a través de los relatos de quienes allí viven y trabajan. No es difícil un trazado analógico de lo que acontece en la creación de un barrio de este tipo y aquello que sucedió durante los planes quinquenales peronistas, tanto a nivel de materialización del acceso por parte de los sectores populares, como las reacciones y los mitos generados por las clases socioeconómicas más altas ${ }^{118}$ (Barrios y Fernández, 2008).

Además, en el cantri acontece un proceso transformador. Pretende ser transformador de los vínculos, de los espacios, de los tiempos, de los agentes institucionales que operan en el policiamiento cotidiano. Por qué no, también transformador del trazo entre adquisición, posesión y propiedad.

${ }^{117}$ Leandro Despouy, titular de la Auditoría General de la Nación, dice: "En Jujuy, el programa social de fortalecimiento del hábitat que encara Milagro Sala, hemos visto ahí enormes dificultades sea el modo en el que se canalizan los fondos, sea la precariedad de la vivienda. Y un sistema muy particular que es el tema del secuestro de los títulos. Las personas llegan a vivir en las casas pero nunca tienen la transferencia, que es una manera de tenerlos cautivos (...) La familia ya está viviendo y no le llegan los títulos. De esa manera se entiende que uno tiene que responder políticamente o clientelarmente a quien se la ha otorgado" (Despouy, en 'Un Mundo Roto', AM La Once Diez, el 20/08/14).

"La 'casa digna' a cambio de presiones y trabajos mafiosos para Milagro Sala. La gente no tiene siquiera las escrituras de su propia vivienda" (@flor923, tweet del 03/08/12, 3:38PM). "El 'Perro' Santillán a la carga: Sólo se puede tener una vivienda si estás en la Tupac Amaru de Milagro Sala. Política social K” (@chavotripero, tweet del 30/07/11,5:21PM).

118 "Incluso en nuestros días es posible escuchar historias que cuentan aquellas atrocidades cometidas por los nuevos habitantes que ponían plantas en los bidets, criaban chanchos en las bañeras, levantaban los pisos para hacer asados, rompían por falta de costumbre el equipamiento de cocinas y baños, o eran delincuentes y vagos" (Barrios y Fernández, 2008: 15). 
Vamos a ensayar a modo de ejemplo lo que aconteció en la conformación de los lotes cocaleros en el Chapare (Bolivia), de acuerdo con la etnografía de Spedding (2005), citada por Stefanoni y Do Alto (2006). Esta región es cuna del movimiento cocalero que sentó las bases para llevar al Movimiento al Socialismo (MAS) y a Evo Morales a un gobierno, desde entonces, plurinacional. Es también una muestra eficaz y vigente de una experiencia coordinada de organización política territorial a partir de la confluencia de una población heterogénea (ex obrerxs minerxs, indígenas, campesinxs). Los sindicatos locales otorgan los loteos para la producción familiar con la consigna de, además, participar de las tareas comunales de infraestructura (hacer caminos, construir escuelas, etc.) Así también, se asume un compromiso de participación en protestas, cortes de ruta y la asistencia a las reuniones sindicales. Los sindicatos, a su vez, tramitan los títulos de la tierra, median disputas entre terrenos linderos, e intervienen en conflictos de herencias o conyugales. En esta experiencia "al igual que en el resto del mundo andino, la propiedad de la tierra está ligada al cumplimiento de responsabilidades políticas locales que consolidan un espacio denso de deberes y derechos colectivos en torno al sindicato" (Stefanoni y Do Alto, 2006: 38). Más allá de normativas que convalidan dichas prácticas en esos contextos a nivel estatal, esta es una experiencia de operación comunitaria en la que coexisten una designación por la propiedad colectiva y una posesión privada de los bienes $^{119}$.

Hemos aludido repetidamente a lo comunitario. Sin embargo, por momentos parece poco

119 Podríamos aludir también a la noción de etnoterritorio (Bartolomé, 2010) como parte de la definición del territorio en las disputas por sus lógicas simbólicas étnicas, en una conjugación de cultura, identidad, historia y espacio. Sin embargo, la condición de 'colonización' de un territorio no habitado como es el caso de El Chapare hace más asimilable la comparación con la identificación colectiva a partir del encuentro en un nuevo territorio. 
eficaz frente a los anclajes subjetivos en los que se estructura la convivencia. Hay una genealogía de fondo en la noción de lo comunitario, genealogía no necesariamente procesada en el desenvolvimiento de la vida, pero que reflota como pulsión productora en un momento de descomposición, y como noción conservadora ante lo obtenido.

Hay una apuesta por una restitución de lo colectivo, pero ello significa un precio alto por costear. Los logros materiales de lo popular no descansan sobre lo obtenido, sino que históricamente se han visto y se ven fustigados por los sectores dominantes. Se dirimen de frente con sectores encolerizados que sostienen en pugna las disputas por las balanzas distributivas. Más allá de lo material y lo económico, la reconstrucción de algún tipo de lazo social requiere de márgenes de protección recia y liderazgos fuertes.

Pero esto refiere también a una agencia popular que adrede desoye a un sector del Estado y los sectores hegemónicos. Viabilizan otro modo de convivencia, una modalidad diferente de la administración del recurso (no como paliativo, no como asistencialismo, no como dádiva) y lo convierten en un proyecto difícilmente asimilable.

La actuación por la preservación se sostiene en una intervención consciente sobre retóricas que mediante artilugios discursivos del republicanismo y la libre expresión han proclamado un proyecto difamatorio durante los últimos años. La asimetría en el reparto de discursos visibles opera como coerción permanente que los constriñe a proteger impetuosa e implacablemente la calle, el barrio, el colectivo reunido, lo que se discute en asamblea, etc. Lo problemático en esto radica en que dicha salvaguardia busca los recursos dentro del derrotero de métodos y estrategias más fácilmente reconocibles como de protección y cuidado; métodos que, por otra parte, pueden inscribirse en lógicas pleiteantes y agresivas. 


\section{SEGUNDA PARTE. APROXIMACIONES DESDE LA CRÍTICA CULTURAL}




\section{MANIFESTACIONES Y ESCENAS DE VISIBILIDAD}

\section{1. Traducciones teóricas posibles acerca de la multitud}

Si algo queda claro es que la presencia visible de la Tupac genera la evidencia del conflicto y la diferencia; quita las estrías de un espacio aparentemente cerrado y homogéneo, y deja manifiesto que el espacio puede también ser un campo para lo múltiple y lo rizomático en el movimiento (Deleuze y Guattari, 2004).

Podríamos arrojar una primera definición acerca de las manifestaciones y la aparición de lxs tupaquerxs en la escena pública local. Asumir, por ejemplo, tres dimensiones de las militancias en la Tupac, en tanto que movimiento político populista: "la equivalencia entre las demandas insatisfechas, la cristalización de todas ellas en torno de ciertos símbolos comunes ${ }^{120}$ y la emergencia de un[a] líder cuya palabra encarna este proceso de identificación popular" (Laclau, 2007: 58). Podemos asumir entonces que existe en la conformación de la Tupac como movimiento político una condensación de significados con una racionalidad propia que intervienen en la esfera pública (Laclau, 2011).

La instancia productiva de la máquina hegemónica es también evidenciada en el punto

${ }^{120} \mathrm{E}$ símbolo en común más emblemático en este caso, fue la consigna que nombra las demandas insatisfechas que venía a 'llenar' la Tupac: "Por más trabajo, educación y salud". También podrían considerarse como parte de los símbolos aglutinantes la puesta en valor del indigenismo -materia pendiente histórica en la región-, las luchas por la verdad, la memoria y la justicia, y la histórica demanda por los elementos de 'lo local' de cara a la figuración predominante de 'lo federal' en Jujuy. 
transitorio de estabilización que supone la Tupac. Podríamos hacer una abstracción formal del proceso histórico y considerar, con Butler (2011b) y Laclau (2011), la lógica de la disputa en el campo político en tanto que la hegemonía no puede clausurarse, lo universal no puede identificarse en su totalidad con un particular y esta inconmensurabilidad deja abierta la vía para asumir que la lucha política es una lucha por (contingentes) universalidades en competencia: la premisa estaría dada por los movimientos tropológicos, es decir, por la emergencia de sujetos.

O ensayar, por ejemplo, el modo en el que lo molar -la ecuación en la que parecen cobrar sentido la representatividad colectiva, la identificación con el liderazgo y el encauzamiento en demandas de reconocimiento de corte global- y lo molecular -la singularización de las experiencias, los carriles del deseo, la hexis militante, o inclusive la marcada sensación situacional de quienes se inscriben en el movimiento tupaquero- funcionan como dimensiones coextensivas $^{121}$. Esta conceptualización no debería interpretarse como una lectura entre lo micro y lo macro, sino que ambas se tejen entre los movimientos emancipatorios, los giros hacia la reacción y la relativa transgresión que parece avizorarse en todas las relaciones visibles del movimiento.

Lo cierto es que cualquiera de estas lecturas antecedentes es aplicable al fenómeno visible de la Tupac Amaru en Jujuy, y, sin embargo, ninguna parece capturarla de lleno. También lo son

121 "No existe lógica de contradicción entre los niveles molar y molecular. Las mismas especies de elementos, los mismos tipos de componentes individuales y colectivos en juego en un determinado espacio social pueden funcionar de modo emancipador a nivel molar y, coextensivamente, ser extremadamente reaccionarios a nivel molecular. La cuestión micropolítica es la de cómo reproducimos (o no) los modos de subjetivación dominantes" (Guattari y Rolnik, 2006: 155 - cursiva en la versión original). 
las nociones de masa y multitud al considerarlas en la agencia y la potencia, más que en el letargo y la inacción. Podemos interpretar a la Tupac tanto como un devenir multitudinario, cuanto como un fenómeno de masa.

Existen ciertas características que atribuye Canetti (2010) a las masas. Utilizaremos algunas de ellas para guiar otra de las interpretaciones en torno al colectivo de la Tupac y aludiremos para ello a algunos de sus argumentos. La masa Tupac no es espontánea, como a veces parece; tiene origen en una masa de prohibición (de huelga, del 'ya no'), pero se constituye en la actualidad como masa de inversión (con una transformación de las jerarquías sociales lenta y dificultosa) y como masa festiva (en la demostración de lo conseguido); fue una masa abierta hasta cierto momento (de aparente ilimitado crecimiento), pero en un amesetamiento de su crecimiento parece constituirse en la actualidad como una masa cerrada (que procura perdurar, más que crecer); hay una identificación (una 'descarga') por la cual se sienten como iguales (aunque está presente el temor de la descomposición y la desintegración); existe en las masas el sentimiento de persecución (externo e interno); lo que genera además la concreción bien delimitada de una masa a la cual oponerse (la confrontación representacional es uno de los condimentos para la conservación de la integración).

Por otra parte, las propuestas de Hardt y Negri (2005) acerca de las multitudes -a modo de constelación de poderosas singularidades, que generan proyectos constituyentes creativos, pero en donde se pueden llegar a percibir correspondencias entre secuencias eventuales de resistencias específicas y fuerzas globales- permiten incorporar el lugar de la potencia en dicho devenir. Rescatamos además de este concepto el valor de las singularidades, no como solución al reconocimiento de las individualidades y la heterogeneidad colectiva, sino justamente por 
atender que más allá de una afirmatividad de las identidades, lo que se proponen las multitudes contemporáneas es replantear la posibilidad de su autodeterminación.

Sin embargo, consideramos relevante destacar en la multitud Tupac Amaru y en otro tipo de multitudes, la articulación política necesaria que viabiliza su concreción, pero que no parece del todo profundizada en los planteos antes expuestos. La multitud encuentra su sustancialización en la articulación, no en la mera unión de singularidades. "La multitud no es un arremolinamiento de desorganizados, sino, por el contrario, una acción organizada de personas organizadas previamente" (García Linera, 2009: 381). En este sentido, aludimos a la noción de multitudes articuladas para pensar al movimiento analizado, es decir, pensamos en la congruencia de fuerzas sociales, pluralidad de demandas, y un horizonte constituido por el deseo.

En la escena pública-política de la Tupac Amaru, como en distintos movimientos sociales de este tipo, convergen así las imágenes gregarias de la masa, la pluralidad de lo multitudinario en la contemporaneidad, la articulación de esas multiplicidades en demandas, y la figura de un liderazgo que se acompaña empeñosamente.

Sin embargo, por el momento no podemos procurar continuar sistematizando una multitud que consideramos que, más que por su coherencia interna, se anuda en gran medida a partir de la madeja que se teje desde la mirada aparentemente ajena, siendo que esto ajeno no corresponde exclusivamente a lo externo. Esta mirada ajena no se hace exclusivamente desde una mirilla inversa, sino inclusive como parte de la lupa con la que cada unx de lxs que están adentro parece 
mirar a quien estuvo a la par $^{122}$. Hay en la pasión por señalar ${ }^{123}$ una intención por muñirse de expectativas respecto de la anomia social a fin de proyectar los temores más generalizados sobre un grupo caracterizado ${ }^{124}$.

\section{2. Acción, reacción; presencia y violencia}

Para iniciar un recorrido por las escenas visibles de la Tupac es necesario asumir dos instancias como punto de partida. Primeramente, consideramos al espacio de ciudad como un espacio constituido en tanto tejido simbólico a partir del cruce entre espacio social, espacio mediático, espacio virtual, cuerpos, y la dimensión política de cada uno de estos elementos. Por otro lado, que la elaboración hegemónica se articula a partir del reclamo de pertenencia exclusiva por parte de solo algunos de los sectores sociales y actores. La progresión de la vida en la ciudad, su experiencia y su significación, parece entonces desenvolverse en la rutinización y estabilización que se articula en el ejercicio y el sostenimiento temporal de los sentidos más fuertemente impuestos acerca de la experiencia corporal urbana. El espacio de ciudad también implica "quien puede tomar parte en lo común" (Ranciére, 2014: 20) ${ }^{125}$.

122 Lo que ha resultado históricamente relevante es distinguir las diferencias entre el individuo aislado y aquel convidado a la masa (Le Bon, 2000 [1895]; Freud, 2013 [1921]).

123 "Nada teme más el hombre ( $\mathrm{sic}$ ) que ser tocado por lo desconocido. Desea saber quién es el que le agarra; le quiere reconocer o, al menos, poder clasificar. (...) Sólo inmerso en la masa puede el hombre (sic) redimirse de este temor al contacto" (Canetti, 2010: 7-8).

124 Dice Sartre acerca de la afección monoideísta pasional hostil hacia un grupo: "Se adelanta a los hechos que deberían hacerla nacer, va en su busca para alimentarse de ellos, hasta debe interpretarlos a su manera para que se vuelvan realmente ofensivos" (1948: 16).

${ }^{125}$ Estiramos aquí parte de las definiciones estéticas de la política por parte de Ránciere, al considerar a lo político como el reparto de lo sensible: el "sistema de evidencias que al mismo tiempo hace visible la existencia de un común y los recortes que allí definen los lugares y las partes respectivas (...). El reparto de lo sensible hace ver quien puede tener parte en lo común en función de lo que hace, del tiempo y el 
Sin embargo, cuando el constreñimiento de la politicidad de la ciudad parece agotarse en la ciudadanía formal del voto, le ocurre a la praxis generalizada de la experiencia urbana una sensación de aberración frente a todo aquello que no se corresponda con lo esperable según las contemporáneas lógicas de la ciudad. La interrupción del flujo y la condición vectorial del tránsito, la movilización de lo marginal hacia lo céntrico, o cualquier evidencia de una disrupción de sus códigos administrativos y civilizadores continúa generando reacciones sarmientinas acerca de la presencia de lo indeseado y lo no viable en las pretensiones hegemónicas de ciudad, traducidas en la actualidad sobre todo a partir de discursos vinculados a los pánicos morales (Thompson, 2014), al temor y al punitivismo de la conflictividad social (Rodríguez Alzueta, 2014).

Las organizaciones acá pelean por el aguinaldo, por plantas permanentes, por suba de sueldos, por los jubilados. Siempre están peleando. Si vos no peleás, no vas a conseguir nada. A veces no te dan bola en las marchas. Entonces, qué tenés que hacer, tenés que ir y reventar las puertas de la casa de gobierno, quemar gomas, hacer carpeadas. Porque si no, no te van a escuchar, vos le vas a pedir de buenas, no te van a dar. Y algunos critican a las organizaciones, pero cómo no critican a los políticos esos a los que vos les vas a pedir de buena manera y no te dan. (...) Para mí están bien las organizaciones porque se hacen escuchar. Un montón pueden decir que son una manga de vagos. Pero cuando suba la luz, todos van a hacer aca a EJESA ${ }^{126}$, y no es solamente para la Tupac o para las organizaciones,

espacio en los cuales esa actividad se ejerce". (2014: 19)

${ }^{126}$ Empresa Jujeña de Energía S. A. 
es para todos. (Militante-Obrera, entrevista de junio de 2008).

A veces a la gente no le gusta y dice 'uh, ya vienen esos patoteros' o hablan en las noticias de la Milagro, 'uh ya vienen a ensuciar la plaza Belgrano, a romper las plantas'. Hay gente que habla así. (Militante-Obrera, entrevista de noviembre de 2010)

Mi tío Manolito nos ve que estamos marchando, manifestando y yo le grito: “¡Manolito!” y no me da bola. "Los voy a cagar quemando, les voy a tirar piedras a esos", así dice mi tío después. (Militante-Obrera, entrevista de diciembre de 2010)

Por eso te digo que me indigna a mí que si hay alguien, algunos que hablen mal de nuestra mamita, porque yo la considero mamita a la Milagro ${ }^{127}$, si llegan a hablar mal de la organización es porque son unos hijos de puta, discúlpame la expresión. (...) Las cosas que el otro día he escuchado, a nosotros nos indigna. Pero nosotros a ellos, les hacemos ver con hechos. No le tenemos miedo a nada porque nosotros acá está todo bien presentado. Y vamos a salir adelante, no vamos a bajar los brazos, no le tenemos miedo a nadie. (Militante-Obrera, entrevista de septiembre de 2010).

${ }^{127}$ Esta figura maternal nos habla de la fuerte carga emocional que suponen los populismos, por una parte por las figuras de identificación mediante las cuales se los significa y, por otra, por la cercanía que se les atribuye a lxs líderes. Por otro lado, el modo en que se configura un rol de aprecio y respeto hacia una figura carismática fuerte y en un rol de liderazgo presenta de modo evidente el quiebre entre lo que significan las imágenes de varones y de mujeres. No es común encontrar a líderes varones identificados con la figura paternal por parte de sus seguidores; sin embargo, para muchas mujeres en estos roles -Eva Perón, sin ir más lejos- es más recurridamente observable el modo en el que comúnmente se las encasilla en estas figuras. 
Existen acerca de la presencia visible de la Tupac en las calles de la ciudad muchas consideraciones posibles. Parte de las interpretaciones de lxs militantes se vuelcan a considerar que lo que se consigue es fruto de la lucha y la presencia en la calle ${ }^{128}$. Otrxs comprenden la presencia en la calle como un gesto de apoyo hacia el liderazgo de Milagro Sala, que es, según estas lecturas, la que posibilita cada nuevo logro. Otras lecturas, menos comunes pero también escuchadas en el campo, extienden la presencia en las manifestaciones, las protestas y los festejos a repertorios más habituales de otros ámbitos, como la presencia en una hinchada de fútbol, la acumulación de historias de barrio, o el encuentro con amigxs y conocidxs. Se contrastan y conviven entre lxs militantes estas lecturas aparentemente despolitizadas -que interpretamos como otro tipo de politicidad ${ }^{129}$ - y aquellas que conciben de modo relevante la injerencia de su presencia en las calles de la ciudad. Más allá de cada concepción, el desborde de las corporalidades que genera algún tipo de disrupción sobre la rutina estabilizada supone un intercambio simbólico que vale la pena considerar en términos de acontecimiento político.

En contrapartida, y como parte de esta disrupción, distinguimos por parte del resto de la comunidad otras percepciones. Se expresan desde distintos sectores instancias de aversión que generan -y que ya se dibuja de alguna manera en los comentarios de estas militantes-, así como la apatía, sensaciones de peligrosidad, de desprecio, e inclusive actitudes aniquiladoras.

${ }^{128}$ Esta acepción es compatible con la percibida en muchas de las investigaciones acerca de la consecución de objetivos demandados al Estado a partir de la lucha (Svampa y Pereyra, 2003; Manzano, 2014; Alzina, 2012; Mezzini, Labecki y Bráncoli, 2010).

${ }^{129}$ Una interpretación acerca de estas prácticas que nos lleva a la posibilidad del aguante como politización resistente, en un concepto alejado de lo propuesto por Alabarces, Garriga Zucal y Moreira (2008) y más bien cercano a lo que advierte el Colectivo Juguetes Perdidos: "Vemos el aguante, no como un goce hedonista e indiferente hacia el otro, lo vemos como una micro-resistencia que se activa en múltiples y diferentes espacios de una sociedad precaria, desde los espacios de laburo, hasta los espacios de entretenimiento. (...) Toda afirmación en la precariedad aprende a resistir a los tropezones, instintivamente" (2011: 54). 


\section{Vamos \#Jujuy: "HAGA PATRIA Y MATE A UN TUPAQUERO".}

(@JujuyEnTuiter, tweet del 21/11/14, 7.49 PM)

\#Fellner dice "El kumpaje \#maraca tupaquero piensa que \#Jujuy es un corsódromo? Que se mueran de sida de una vez. ${ }^{130}$ (@ChauFellner, tweet del 20/11/14, 11.02 PM).

Negro tupaquero olor a cloaca. (@Valejuarezz, tweet del 13/10/13,2.59 PM).

Me cruce una gorda q le enseñaba a su bebe "tupaquero carajo" \#AsiEstamos. (@sofistacchiola, tweet del 06/09/13, 3.07 PM)

En un confuso incidente, dos personas resultaron heridas de bala durante una caminata de campaña de Milagro Sala, líder de la agrupación Tupac Amaru, que calificó el ataque como una "emboscada" y un atentado contra la candidata a diputada provincial en Jujuy. (...) El fiscal de la causa, Aldo Lozano, brindó una conferencia de prensa en la que mostró total coincidencia con la denuncia de la Tupac Amaru, al afirmar que "una cantidad de 10 individuos realizaron una especie de emboscada" contra los seguidores de Sala. El funcionario aseguró que "los disparos fueron realizados a matar", razón por la cual caratuló la causa como homicidio calificado por el concurso premeditado de dos o más personas en grado de tentativa. ${ }^{131}$ ("Una agresión contra la agrupación de Milagro Sala avivó la

${ }^{130}$ Fecha correspondiente a la marcha del orgullo LGBT organizada por el área de diversidad de género de la organización.

131 "El senador jujeño Gerardo Morales responsabilizó hoy a la dirigente de la Tupac Amaru, Milagro Sala, del 'clima de violencia' que desembocó en un atentado hacia su persona y acusó del hecho a 'una pelea de mafias' dentro de la organización, a la que comparó con una interna entre 'barrabravas"” "Morales 
violencia”, en La Nación, 23/10/13).

La condición para llegar a una homogeneización social y al consenso se hace a expensas de que la cultura pública hegemónica resuelva la convivencia mediante el dictamen de la necesidad de la 'eliminación’ del antagonismo. Según esta apreciación sacrificial de aquello que genera conflicto, recién se puede concebir a nivel local la convivencia democrática una vez expulsada la diferencia (Kaufman, 2011).

Se tejen y se han tejido históricamente discursos en torno de la violencia de la Tupac Amaru, cuyos estatutos de verdad y mentira no son debate en esta tesis. Lo que sí queda claro es que existe en razón del intercambio simbólico e interaccional entre los distintos sectores que se articulan alrededor y en contra de ella en el intercambio político jujeño una acumulación discursiva basada en la posibilidad latente de la aniquilación de lo diferente. La disposición hacia la violencia requiere no de la averiguación de lo factual, sino del sometimiento a crítica del por qué es que pueden sostenerse movimientos transformadores con modalidades diversas del ejercicio de la violencia. Y con esto hablamos no sólo de la organización sometida al análisis más profundo, sino a todos aquellos movimientos sociales, actorxs políticxs, partidos tradicionales, sectores institucionales y discursos mediáticos masivos que han sostenido e instigado cada uno de los episodios asimilados a la historia de la Tupac. Después de todo, planteamos en esta tesis a la Tupac Amaru como muestra o evidencia de procesos históricoculturales previos y vigentes.

relativizó el ataque a Sala: 'Es una pelea de mafias' entre la Tupac”, en Perfil, Disponible en http://www.perfil.com/politica/Morales-relativizo-el-ataque-a-Sala-Es-una-pelea-de-mafias-entre-laTupac-20131022-0029.html visto por última vez el 09/09/15). 
Dicho esto, podemos afirmar que la Tupac Amaru ostenta hoy en día no sólo la aparente monopolización de los recursos económicos nacionales destinados a la acción colectiva en la provincia, sino también, y de manera más destacada, la monopolización de un nudo sensible de las fibras de la violencia social. Es catalizadora simbólica de actitudes, no solo destituyentes de la institucionalidad política, sino de las más claras muestras de que los virajes del exterminio histórico latinoamericano y argentino continúan habitando el imaginario cultural acerca de cómo resolver el problema con el otro.

\subsection{Uniformadxs y dirigidxs. Ovejas, esclavxs y el ejército comandado por Milagro} Sala

En la transición simbólica por la cual se ha acostumbrado nombrar a lxs militantes de la Tupac Amaru y a Milagro Sala como sujetxs violentxs podemos incorporar otras tres vías discursivas sobre las que se sostienen estos andamiajes de sentido. Por un lado, un discurso escuchado y leído habitualmente que identifica a lxs militantes como esclavxs, ovejas o como soldadxs de un ejército. Por otro lado, y en la misma vía, la noción que asume que parte de esas lógicas de militarización se corrobora o convalida en su vestimenta y en su forma de actuar en masa. Por último, el rol de Milagro Sala como “dueña” autoritaria de este ejército.

En muchas de las manifestaciones registradas en video de los primeros años de la organización, cuando aún no estaban unificados los uniformes de trabajo (overoles, remeras con la identificación de la Tupac o de Unidos y Organizados), gran parte de los convocados desfilaban sin remera, con la camiseta de la selección argentina o con la de Gimnasia y Esgrima de Jujuy. 
Con los años, se modificó la estética colorida de las marchas y se fueron unificando el uso de dos colores a modo de identificación por parte de lxs militantes. Primeramente, las remeras blancas con inscripción en letras y símbolos color negro del logotipo de la organización, que a partir de la muerte de Néstor Kirchner también sumaron gráficas del matrimonio de presidentes, las leyendas "El amor vence al odio" y "Unidos y Organizados"; por otro lado, el color beige de los overoles de los cooperativistas de construcción; y, por último, el uso del mismo color de manera más marcada en las remeras a partir de la fundación del Partido por la Soberanía Popular.

El uso de las remeras, las gorras con inscripciones de la Tupac, los overoles, las camisas y los pantalones de trabajo con la identificación de la organización, así como el uso de chaquetas médicas y delantales ${ }^{132}$ fueron señalados y criticados en la intervención del periodista Jorge Lanata, refiriendo a una militarización de sus prácticas.

Hay distintos tapes en donde se ve a gente de uniforme marchando, capaz es una cuestión de diccionario, si todo el mundo tiene la misma ropa y el mismo color se le llama uniforme en español. Vi videos en los que están le gente con uniforme y con los palos iguales. Desde Buenos Aires no se entiende, porque se ve gente que a la vez está haciendo una obra y que a la vez usan métodos que suenan raros. Me suena raro ver a seiscientos tipos haciendo el saludo de 'Tupac, Tupac' [el periodista levanta el brazo en posición perpendicular a su cuerpo mientras dice esto] porque parecen las juventudes hitlerianas. (Jorge Lanata, en Periodismo para todos, 5/08/12).

132 Toda la indumentaria enumerada es manufacturada en las instalaciones de la fábrica textil de la organización en Alto Comedero. 
Ambas expresiones subrayadas en el fragmento dan luz al tono de condescendencia del intercambio entre el periodista y 28 militantes de la organización junto a Sala en una entrevista colmada de expresiones de ese tipo. No es casual, ni menor, el hecho de que un periodista blanco, que atravesó por la educación formal, capitalino, varón se refiera a lxs integrantes de la Tupac (en su mayoría mujeres, de tez morocha, rasgos indígenas, jujeñxs) haciendo alusión al correcto uso del lenguaje español en modo displicente.

La modalidad en la que podemos medir aquello que acontece como discurso, como crítica, y como injuria en las esferas mediáticas y virtuales dificulta el sostenimiento de un diálogo entre voces equiparables. La generación de contenido mediático y digital masivo y los contenidos producidos en las interacciones virtuales tienen un peso destacable en lo que refiere a la plataforma de sentidos que circulan y se reproducen. Se conoce que existe un altísimo consumo mediático a nivel nacional ${ }^{133}$. En particular, el programa mencionado tuvo en ese año un rating promedio de 15.7 puntos $^{134}$. Por otro lado, los veinte videos más vistos en Youtube con la búsqueda Milagro Sala tienen 1.119.250 visitas promediando la segunda mitad de 2015. Cuatro de ellos refieren al episodio con Lanata, otros cuatro, a situaciones en las que la dirigente insulta o agrede verbalmente (según los títulos de los vídeos), el resto se dividen en alusiones a su 'ejército', documentales, protestas, proselitismo, etc.

El efecto dramático del episodio de Lanata, o de los videos fragmentarios en internet, son recortes de un aparato injurioso. La crítica al proyecto político de la Tupac Amaru opera casi

\footnotetext{
${ }^{133}$ De acuerdo con la Encuesta Nacional de Consumos Culturales y Entorno Digital (2013), el 98\% de 1xs argentinxs miramxs televisión en un promedio de casi tres horas por día.

${ }^{134}$ Lo que equivale según las mediciones a un millón y medio de personas solo en ciudad de Buenos Aires y el Gran Buenos Aires.
} 
exclusivamente por los carriles del campo discursivo difamatorio respecto de las formas de ejercicio de la violencia que evidencian. Y ante la violencia se disipa cualquier argumentación respecto del proceder político y se traslada el foco comprensivo a las únicas aparentes vías de incorporación: la adhesión o el rechazo. Parece por momentos inaudible la voz política.

Ante el panorama acontecido en agosto de 2012 con la producción periodística que aparece en el cantri con una cámara oculta ¿Por dónde se podían considerar los argumentos en defensa de una situación de 'agresión' de este tipo? Si es por momentos tan difícil incorporar una voz política crítica en la esfera mediática pública ¿De qué manera discutir frente al recorte permanente que los deja escénicamente violentxs?

Durante toda la reunión Milagro se preocupó por mostrarse amable, pero al mismo tiempo, poderosa. Rodeada de militantes y con cámaras que registraron cada uno de nuestros pasos. Afuera en la calle, cientos de personas la apoyaron con banderas y un canto que no se interrumpió ni un segundo mientras estuvimos ahí. Durante una hora corearon lo mismo: "Somos buenos, nosotros somos buenos, nosotros somos buenos". Un mensaje para nosotros, o una oración de auto-convencimiento. (Jorge Lanata, en Periodismo para todos, 5/08/12)

Y aquí quedan en evidencia dos de los modos de respuesta. El primero, la respuesta mediática alternativa. Decenas de cámaras grabaron toda la mesa de diálogo entre militantes y periodista. Se evidencia el contraste entre uno y otro documento, en la preponderancia de la toma de la palabra y en la agenda de discusión. Mientras en el programa de Lanata predomina la voz del periodista y se acentúa la intención paternalista (patriarcal) por parte del entrevistador, casi 
unívocamente aconsejando a la dirigente; en el documento alternativo se escuchan en mayor medida las voces de lxs militantes, se describe la producción, los métodos y la documentación de las obras, y se da una discusión respecto del rol empresario en la provincia.

El segundo método es el que más logra avasallar al periodista. Adrede, como masa, copan la calle en la que está ubicada la sede central de la organización cientos de militantes que responden a la Red de organizaciones sociales. Sobre la calle, las veredas, las terrazas de los edificios de la cuadra, con banderas y con predominancia de los tonos de los mentados uniformes, una aglomeración de cuerpos que saltaban, gritaban y cantaban vitoreando “iSomos buenos!”. Este despliegue escénico que busca hacer sentir al grupo periodístico el peso del colectivo se da a la despedida del periodista, y mientras su vehículo se aleja, la multitud avanza cantando y acompañando el movimiento del rodado. Esta es una respuesta a la voz mediática masiva y al poderío de la voz del periodista político. Es una respuesta desde los cuerpos en la calle. Y es una maniobra irónica que, a la vez de proclamar benignidad, parece intentar escarmentar al invitado.

En otras cuestiones, en la comparación con un batallón militar, esclavxs u ovejas, se equipara en cualquiera de estos conceptos la falta de agencia individual y colectiva por parte de lxs tupaquerxs. Aún más allá, se les atribuye con cada una de estas lecturas sobre las masas la incapacidad de libertad: el carácter de unidades militarizadas sometidas a un comando de liderazgo, el mote del sometimiento a ser propiedad de alguien más, o la calificación de un ganado que se mueve en manada dirigida. No es novedosa la subestimación hacia los sectores populares movilizados, ni la estigmatización por la vía de la peligrosidad en el conjunto; las traducciones más comunes se encuentran en las lecturas del clientelismo, las típicas expresiones alusivas a la transacción de la presencia movilizada por la comida o por el plan social, o el 
despertar de los pánicos y la turbación, y la respuesta represiva hacia la acción colectiva.

Lo que sí se ha señalado de manera más plausible en la construcción social de estos sentidos en el caso de la Tupac es el foco que se pone sobre el supuesto liderazgo de esa militarización o conducción guiada hacia la violencia en la figura de Milagro Sala. No es, en muchos de estos eslabones de percepción y de sentido, mera metonimia del carácter violento colectivo, sino que se elabora su accionar como instigadora inmediata del envilecimiento popular colectivo.

Mientras una veintena de hombres apedreaban, mostraban pistolas y escopetas y disparaban contra lxs militantes de la Tupac, saltaban y les cantaban "Esclavos, esclavos, esclavos". (Notas de campo. 22/10/13 ${ }^{135}$ )

@MassiGuerraO jajajajajajajajaja trabajar en la Tupac? Ahí sos esclavo, no trabajador xD una vez que entras te reprimen y obligan (?) ha ._.(@AriOutspoken, tweet del 19/02/13, 8.13 AM)

@ AriOutspoken medio hitler es la mili salas :s ah. (@MassiGuerraO, tweet del 19/02/13, 8.15 AM)

@MarcePCsolution esa es la gente de Milagro Sala, busca los vídeos de ellos, parecen un ejército con uniformes caqui. (@MartinSOjeda, tweet del 2/03/15, 8.24 AM)

${ }^{135}$ Este episodio alude a la situación de violencia pergeñada en el Barrio Mariano Moreno de la ciudad capitalina mientras transcurría una de las caminatas de campaña electoral de cara a las elecciones legislativas de 2013. El tiroteo fue considerado por la Tupac una "emboscada para matar a Milagro", por el senador Gerardo Morales un "enfrentamiento entre mafias", y el caso fue caratulado como "Homicidio calificado por el concurso premeditado de dos o más personas en grado de tentativa" por la fiscalía jujeña. Imágenes del episodio disponibles en: https://www.youtube.com/watch? $\mathrm{v}=Z \mathrm{~V}$ suActJDrY visto por última vez el 10/09/15. También disponibles en los anexos. 
La piquetera jujeña Milagro Sala dispondría de un ejército de 10.000 militantes armados, listo para entrar en acción. (@DrFreedomAR, tweet del 18/02/15, 5.27 $\mathrm{PM})$

Milagro es una mujer de entre 50 y 60 años, de tez morena, rasgos indígenas, 1,60 y no más de 50 kilos (de acuerdo con la descripción del diario Clarín). Habla con acento jujeño muy marcado, muy diferente del porteño; sus palabras se entrecortan y arrebatan cuando habla exaltada; gesticula y sostiene sus expresiones con muchos ademanes; utiliza malas palabras o expresiones vulgares para hablar; no se incomoda al gritar organizando las filas de una marcha que la tiene a ella a la cabeza; y su presencia en general resulta avasallante. Estas caracterizaciones se suman a la elaboración de sentidos dominantes acerca de ella como 'violenta', 'agresiva' o 'machona'.

Tabbush y Caminotti (e. p.), al indagar en el modo en el que se elaboran los afectos públicos respecto de la líder y de la organización a partir de cómo es representada mediáticamente la Tupac Amaru, consideran que 1xs militantes son 'impregnados' de características negativas en su forma de hacer política.

Lo hacen a través de dos cadenas de sentidos: una centrada en la corrupción que cristaliza acusaciones de clientelismo e ilegalidad, y una segunda en torno al manejo y uso de la violencia que define a La Tupac Amaru como grupo de choque, armado, revolucionario y/o guerrillero. (Ibíd.: s/p)

Y, en lo que respecta puntualmente a Milagro Sala, de acuerdo con las autoras, los diarios construyen de ella una imagen de mujer racializada de los sectores populares que condensa en sí los usos de la violencia, las armas y una marcada "ausencia de feminidad". 
Entre los discursos observados se evidencia la incomodidad que genera que una mujer con alto perfil político no adhiera a elaboraciones más tradicionales de la vinculación mujer-política. Pero más aún, que esa mujer no reúna las cualidades de las mujeres arquetípicas en el ámbito público; que se presente de manera $b u t c h^{136}$, inclusive que sus rasgos o su acento no respondan a los más comúnmente encontrados en los medios o en la política.

La materialización performática de un cuerpo por fuera de la norma de lo permitido y lo visible tiene como respuesta reacciones agresivas que terminan reconociendo esa corporalidad de uno de los lados del binarismo, objetándola por esa vía.

Milagro Sala tiene pija chica. (@GarKaAbierta, tweet del 4/8/15, 11.37 PM).

¿Milagro Sala es travesti? Es pregunta retórica. (@Angustias_, tweet del 9/8/15, $2.22 \mathrm{PM})$

Y la negra pata sucia de la Milagros Salas ya es legisladora del Parlasur? O la mataron de un alpargataso [sic] por fea? (@Artiaguito, tweet del 11/8/15, 6.16 PM) MILAGRO SALA, irrumpió en el Concejo Deliberante local. Otra \#Hitler fabricación Nac\&Pop. Es una millonaria poderosa con fuerza bruta. (@aloMecha, tweet del 19/12/14, 9.43 AM)

Milagro Sala sos un macho en pinta! Toba de mierda. (@gisellersalinas, tweet del 24/10/13, 9.11 PM)

En \#Jujuy o votas al travesti de Milagro Sala o te cagan a tiros... Otro mounstrito

\footnotetext{
${ }^{136}$ La traducción más sencilla sería machona.
} 
[sic] creado por los K.. (@JoseGerard, tweet del 23/10/13, 9.58 PM)

Estas reacciones, que también tienen un fuerte componente racista, clasista y xenófobo, vuelcan gran parte de sus comentarios a identificar la no adscripción a lo que se espera de una mujer pública, con cuestiones de sexualidad, atravesada por la raza, la etnia, la clase y la educación.

Más allá de cualquier reflexión acerca de la agencia performática de la líder de la organización, es necesario introducir previamente las nociones de precariedad y violencia como elementos que son parte inmanente de la disposición cultural para la elaboración o materialización del género (Butler, 2008).

¿Por qué hacemos mención a la violencia en esta instancia? Básicamente para poder dimensionar el valor político de la emergencia de sujetxs disruptivxs. No sólo por la performación que de sí misma configura, sino por el rol protagónico que adquiere en sus contextos de desenvolvimiento, reafirmando en su devenir corpóreo parte de los argumentos que la hacen destacable y reconocible. Consideremos que ningún género existe por fuera de las normas imperantes de época. Y que en una elaboración corporal disruptiva, el agente opera en torno de estas precariedades. Entre la auto-afirmación y los movimientos regresivos que operan para intentar reubicarla y señalarla de forma estigmatizante, se encuentra la búsqueda que pretendemos hacer a fin de distinguir el modo en el que la desafiliación de ciertas características normativas sobre sí misma permite imaginar formas de enunciación que arremeten contra las lógicas simbólicas más comunes acerca de la construcción de figuras de poder o en roles de liderazgo.

Este es solo un ejemplo presentado para comprender los procesos de ida y vuelta entre 
precariedad y agencia, en tanto que todas esas características endilgadas como negativas en la líder, son en realidad reivindicadas públicamente por ella como por el conjunto de la organización que dirige: se reconocen como indígenas, como parte de la comunidad LGBT de la ciudad, como pobres, como negros.

\section{4. La escena festiva. Los reyes magos y el día del niño}

“Dije en cierta oportunidad que el país que olvida a sus niños renuncia a su porvenir". Eva Perón, Discurso de la inauguración de la Ciudad Infantil, 14 de Julio de 1949

Año a año, dos festividades clave para la Tupac son el día del niño (primer domingo de agosto) y el día de reyes magos (6 de enero). Se celebran los sábados cercanos a ambas fechas en la intersección del puente Gorriti y la avenida 19 de Abril -ambas, arterias fundamentales de la ciudad-, si bien se extiende hasta la vereda de la casa de Gobierno -ubicada a dos cuadras del puente, en el centro de la ciudad-y a lo largo de alrededor de cinco cuadras de la avenida. Por las épocas del año en las que se lleva adelante, el clima habitual de los últimos festejos ha acompañado con jornadas acaloradas o de viento norte, lo que torna a la masividad en una condensación agitada y febril.

Desde las primeras horas del día, integrantes de las copas y cooperativistas van armando cada mesa de comidas y golosinas, con cotillón y adornos temáticos. Llegan colectivos desde distintos puntos de la provincia para la celebración, si bien, en las semanas subsiguientes, los festejos por cada una de las fechas conmemorativas se replican en otras localidades. 
Cientos de miles de niñxs, jóvenes y adultx ${ }^{137}$ se congregan en una celebración que incluye mesas de comida, golosinas y tortas llevadas adelante por cada una de las copas de leche aunadas en la Tupac. La comida circula además de por las distintas mesas, entre lxs cooperativistas que ofrecen en bandejas al paso todo tipo de entremeses producidos para el evento. Hay decenas de peloteros inflables y toros mecánicos dispuestos a lo largo de las avenidas y el puente, y lxs niñxs saltan de uno al otro, al cuidado de lxs integrantes de copas de leche. Además de los distintos juegos de kermés, hay payasos y shows en vivo a lo largo de toda la tarde en un escenario de grandes dimensiones montado en los días previos frente al puente Gorriti y la calle del mismo nombre. Los espectáculos brindados en general se dividen entre un artista o personaje del ámbito infantil y grupos de cumbia villera destacados a nivel nacional y provincial. Se pasa así, de la concentrada atención de lxs niñxs a espectáculos de tipo teatral, al pogo, el baile y las palmas exaltadas de lxs demás presentes. Por la concurrencia se convierten en festivales de una masividad inusitada en el terreno local en lo que respecta a celebraciones dedicadas a la infancia. El despliegue de los juguetes que se regalan entre lxs niñxs presentes merece una nota aparte. En el año 2014, en conferencia de prensa, la organización reconoció haber adquirido 150 mil juguetes para ser repartidos durante el evento capitalino. En instancias previas al evento se consignan y se muestran en un despliegue a lo largo de todo el terreno de los galpones recuperados en la zona de la estación de trenes: cientos de bicicletas, monopatines, triciclos, andadores, patinetas de dos y cuatro ruedas, coches de bebé, carritos, saltarines inflables de

${ }^{137}$ A partir del año 2010 la cifra habitual ronda lxs más de cien mil invitadxs, según grafican los medios locales. La gran envergadura del evento y la poca o nula representación mediática (sobre todo gráfica) que obtenía en los primeros años era escena de conflicto. Sin embargo, esta situación viró desde hace alrededor de cinco años cuando el evento se comenzó a transmitir de manera simultánea por ambos canales de cable local (Canal 4 y Canal 2); además de ser incorporado a la agenda de muchos portales de noticias y por diario El Tribuno. 
PVC, accesorios de pileta y salvavidas, pelotas de distintos deportes y pelotas gigantes, muñecas, bebotes, cocinas de juguete, autos y camiones, aviones, juegos didácticos, bloques estilo Rasti, barriletes, cosméticos, soldados, juegos de magia, sonajeros.

Tal y como lo describe un diario digital:

[Milagro Sala] También dijo que los juguetes no son chicos, "son grandes porque yo estimo que los niños jujeños tienen que tener la misma alegría que tienen los hijos de los demás". ("Milagro Sala dijo que...”, Diario El Libertario, 10/01/14)

Desde las primeras horas de la tarde se hace entrega de todos estos juguetes. Cada niñx se lleva hasta dos regalos del evento. La premisa "que no se vaya ni un chico sin su juguete" es repetida permanentemente por cooperativistas. En varios momentos de la tarde hacen su llegada distintos camiones con cargas de pelotas de distintos tamaños que son distribuidas a las masas que se lanzan a la búsqueda de alguna.

Para enero en el momento central del festival, entre el despliegue de los peloteros y las mesas de comida, sumado al desfile de los presentes y el baile de algunas de las escuelas de danzas de la Tupac, arlequines, payasos y lobos, en toda una escena repleta de globos, banderines, carteles y banderas que se desparraman por las calles, se abre paso hacia el escenario para el festejo de Reyes Magos un trineo en el que hacen su aparición los tres reyes y un Papa Noel personificado por Milagro Sala, quien desde allí, avienta caramelos para todxs lxs presentes. La imagen se presenta como una obra de Daniel Santoro, con los tonos del justicialismo de la solidaridad en el obsequio acercado, la figura alusiva onírica, y la síntesis de la ilusión de un capitalismo empático.

Más allá de cualquier esfuerzo descriptivo, las sensaciones y el clima que se vivencian al deambular por el festival, el calor que se levanta en la muchedumbre; la exaltación de lxs chicxs 
que corren de un lado a otro en busca de golosinas, comida y juguetes; la efervescencia con la cumbia de fondo y los cuerpos que transitan en hileras al ritmo de la música; el clamor, los gritos, el llanto, las sonrisas, son de una experiencia intensa y jubilosa poco traducible.

Esta es una escena de visibilidad clave en el calendario anual y en la historia de la organización. Esta escena se distingue de las demás descriptas hasta aquí por la evidente latencia positiva, el gozo y la afectividad. La pulsión peronista, que en otros momentos se manifiesta como necesidad de institucionalidad o como demanda por la habitabilidad digna de la existencia, aquí cobra más evidentemente el carácter de capitalismo igualitario. La traducción del deseo por el consumo y la posesión se encuentra en este movimiento con la lógica redistributiva. Se asume que existe una constelación de imágenes que aluden a los bienes como símbolos de algún tipo de pertenencia y al espectáculo como ejecución del consumo. Y se incorporan casi sin mediar crítica estas premisas como parte de las "tonalidades emotivas de la multitud" (Virno, 2008: 89) contemporánea. Pero lo que sí se modifica son las condiciones para el acceso a dichos elementos de valor. Aquí se clarifica de alguna manera que la Tupac Amaru no busca adherir a una moral utópica por fuera de la senda del capital y el Estado, sino que interpreta parte del deseo colectivo y materializa mediante una modificación en la economía de los símbolos la concreción de algunos de esos deseos. Esos deseos, claro está, no son subterráneos ${ }^{138}$, sino que se expresan como vivencia que ha suscitado el dolor de la exclusión por la no posesión.

"Que no se vaya ni un chico sin su juguete" y la tónica general del evento responden a una de las máximas discursivas de la Tupac, que tiene que ver con que todo lo que se hace, se hace para lxs niñxs. Así es como la vivienda se concibe para lxs hijxs, las escuelas y los centros de salud

\footnotetext{
${ }^{138}$ Una definición más profunda sobre el deseo colectivo será desarrollada en el capítulo 6 de la tesis.
} 
sobre todo para lxs chicxs, las piletas para que "ningún chico pase por lo que unx pasó" (frase de Milagro Sala, pero replicada como experiencia personal por muchxs de lxs entrevistadxs), los mensajes de formación intergeneracional, o que los eventos más masivos y notables localmente respondan a fechas que lxs conmemoran opera en la línea de un discurso público que advierte en la aparente desprotección infantil previa, parte de las estrategias discursivas de demanda de pertenencia, además de apelar a una de las bisagras fundamentales del primer peronismo (Carli, 2000), el reconocimiento de la pobreza infantil. El peronismo aquí no es una sustantividad doctrinaria, sino que se ha colado en la praxis y la poiesis. Más allá de estas apreciaciones, estas expresiones también se apegan a discursos históricos respecto del cuidado, la protección, la educación y la represión de lxs niñxs (Carli [comp.], 1999). Asentándose en percepciones sociales que se conciben como valorables se pueden expresar y materializar parte de los deseos multitudinarios ${ }^{139}$.

Todo este tipo de manifestaciones no pueden interpretarse unívocamente como tan sólo una celebración. Sus intervenciones operan como un despliegue en exceso para reubicarse como interlocutores capaces de apropiarse y resignificar los sentidos hegemónicos de la ciudad. Arrogarse la posibilidad de usar estos espacios desde ese lugar, el de un sujeto colectivo visible, es arrogarse la de reconstruir cada espacio desde una nueva lógica de pertenencia (Butler y Spivak, 2009).

139 "Cuando yo era chica había dos piletas, una que usaban los ricachones y los baños públicos donde iba la clase media. Nadie podía entrar si no pagaba. Mis hermanos son blancos, me llevaban, pero no me dejaban pasar. Entonces mi hermano no entraba. A mí me daba odio. No sabía nadar, aprendí ahora. Nos dicen que queremos hacer una revolución. Sí, construir una pileta es hacer la revolución. De mate, de cabeza. ¿Por qué los chicos humildes no pueden tener una pileta de natación? ¿En qué parte de la Constitución lo dice? Y si no lo dice, hay que hacerlo." (Milagro Sala, en "Milagro Sala, esta nena...", Semanario Digital Lo Social, 29-10-09. Disponible en http://www.losocial.com.ar/nota.asp?iddocs=5004 visto por última vez el 05-11-15). 
Por otro lado, este despliegue escénico, además de una muestra de poderío, se instituye como una manifestación cultural poco deseada socioculturalmente a nivel local en razón de quienes detentan ocupar de manera hegemónica el rol de promotores de los valores culturales. Retomemos para considerar un contraste, lo que plantean Burgos y García Vargas (2008) acerca de parte de la red de significaciones dominantes que se construyen en Jujuy en torno de las tradiciones, la identidad y la cultura -a partir de lo planteado por un suplemento de diario Pregón, y sus articulaciones discursivas--. Esta posición articula una apelación estrecha a la cultura en términos de alta cultura (Rist, cit. en Burgos y García Vargas, 2008), la reafirmación como valor de la familia patriarcal -de ascendencia de ultramar-, y una afiliación de sujetxs selectiva que intenta homogeneizar al territorio mediante valores en torno de lo local -en un registro único- y lo tradicional - en una tradición selectiva.

La reivindicación villera en el festival, expresión que tiene origen territorial en la segregación residencial, pone en tensión la cultura dominante en tanto es también una reivindicación de la precariedad de la que se viene, de trayectorias sinuosas, de malestares y de reafirmación del consumo de alcohol y de drogas, de valores con moralidades diferentes de las del 'buen gusto'. 


\section{CONFLUENCIA DE SENTIDOS EN LA OBRA ARQUITECTÓNICA URBANA DE LA TUPAC AMARU}

Este capítulo condensa mucho de lo desarrollado en los demás segmentos de la tesis, pero lo hace con un matiz y una modulación retórica que, creemos, ameritaba la densidad del espectáculo visible. El capítulo representa un paréntesis oportuno que se encauza a partir de un tono y un estilo diferentes del resto de lo escrito. Si bien persigue parte de las mismas preguntas que se sostienen a lo largo de toda la investigación, aquí disponemos a partir de las formas y de los planteos una vía alternativa para el análisis. Está basada en la adopción de una descripción densa, pero por la especificidad de la obra analizada ha requerido de una multiplicidad exhaustiva en la búsqueda de conceptualizaciones, lecturas y teorías que pudieran de alguna manera dar cuenta de lo observado. Embebernos de sus usos, tránsitos y experiencias a lo largo de los años de campo nos situó ante una abstracción tan compleja como fructífera en las reflexiones que nos propusimos a lo largo de la investigación. La intención está puesta en disponer a modo de miradas múltiples, percepciones propias que discurren, se contradicen y aportan diversas categorías con las cuales fuimos pensando el parque en cuestión. 


\subsection{Presentación}

Existe únicamente un ver perspectivista; y cuanto mayor sea el número de afectos a los que permitamos decir su palabra sobre una cosa, cuanto mayor sea el número de ojos, de ojos distintos que sepamos emplear para ver una misma cosa, tanto más completa será nuestro "concepto" de ella, tanto más completa será nuestra "objetividad”. Friedrich Nietzsche. La genealogía de la moral.

La interpretación da por supuesta la experiencia sensorial de la obra de arte, y toma a ésta como punto de partida. (...) La nuestra es una cultura basada en el exceso, en la superproducción; el resultado es la constante declinación de la agudeza de nuestra experiencia sensorial. Todas las condiciones de la vida moderna — su abundancia material, su exagerado abigarramiento - se conjugan para embotar nuestras facultades sensoriales. (...) Nuestra misión no consiste en percibir en una obra de arte la mayor cantidad posible de contenido, y menos aún en exprimir de la obra de arte un contenido mayor que el ya existente. Nuestra misión consiste en reducir el contenido de modo de poder ver en detalle el objeto. La finalidad de todo comentario sobre el arte debiera ser

hoy el hacer que las obras de arte —y, por analogía, nuestra experiencia personal— fueran para nosotros más, y no menos, reales. Susan Sontag. Contra la interpretación.

Como punto de partida presentamos un par de fragmentos que, como palabras de antesala, juegan a contradecirse o se alejan el uno del otro. Los retomamos asumiendo la distancia sensorial, perceptiva y emotiva que parecen oponer a un objeto cualquiera y a una obra de arte. 
Apuestan y se comprometen con lo que significa mirar y sentir. Con ello, interpretar, tratar de dar sentido a algo que, ambos asumen, se escapará de todas formas a cualquier concreción sintética alcanzable. Podríamos dejar abiertas de antemano, también a modo de premisas, las preguntas que se hace Grüner al respecto de lo planteado por Sontag:

¿no se ve que la interpretación no es un mero intento de 'domesticación' de los textos, sino toda una estrategia de producción de nuevas simbolicidades, de creación de nuevos imaginarios que construyen sentidos determinados para las prácticas sociales? ¿No se ve que la interpretación es, en este registro, un campo de batalla? (1995: 11-12 - cursivas en el original).

Esta es la intención con la que interrumpimos una escena de todos los días para atravesarla de lecturas, discutiendo así también su estatuto artístico y productivo social.

El escenario elegido dialoga con la ciudad de San Salvador de Jujuy en su conjunto. La ciudad opera como marca fuerte que cimienta de manera condicionante las razones y contradicciones que se desarrollan como parte de la conformación de un colectivo multitudinario en términos de organización barrial, en general, y con la obra en cuestión, un lugar en particular.

Para la lectura programada miramos y nos movemos entre la ciudad en su conjunto y un fragmento del barrio construido por la organización elegida, en razón de comprender los flujos, articulaciones y reubicaciones de un orden sociocultural en la ciudad, como las expresiones que podrían reactivar deseos y activar otros sentidos locales en torno a la ciudadanía, el capital, el mercado y el consumo, y los modos de pertenencia más tradicionales. 
En esta instancia retomamos al parque del barrio como imagen central, como materialización máxima de conscientes e inconscientes deseos colectivos. Lo consideramos una probable brújula de las pretensiones multitudinarias y un despliegue de espejismos que nos convocan a imaginar sentidos inconclusos en razón de la búsqueda metonímica de este deseo.

Este parque está ubicado en el cantri de la Tupac. Como ya hemos mencionado, el barrio está asentado en un territorio topográficamente complejo, de desniveles, de suelo árido y seco; en realidad, a contrapelo de su desarrollo masivo, poco apto para la edificación y la vivienda.

En este apartado pareciera que por momentos hubiéramos deshabitado al parque de sus multitudes. Es un espacio vacío el que relatamos. No obstante, creemos que a cada expresión hacemos aparecer numerosas voluntades, pretensiones y apuestas, territorializándolo de cuerpos que en definitiva lo hicieron, lo habitan, lo usan y lo viven día a día.

Generamos una serie de miradas múltiples a expensas de una misma escena, sin pretensión resolutiva. El ejercicio pretende abrir distintas vías críticas que no son ni contradictorias, ni coherentes. Al sustraer de una imagen su ambigüedad podemos intentar profundizarla y complejizarla indiciariamente; observar y estimar un abanico de sentidos apelables, sin por ello asumir que es viable explicarla o traducirla. Así, a sabiendas que un ejercicio de este tipo parece "violentar, reajustar, recortar, omitir, rellenar, imaginar, falsear, y todo lo demás que pertenece a la esencia del interpretar" (Nietzsche, 2011: 179), lo hacemos sin intención de reducirlo o alterarlo de manera última.

Las preguntas de este apartado están motivadas en razón de diferenciarnos de ciertas lecturas valorativas en torno de la movilización colectiva en estos términos. Cierta manera de abordar la 
situación de esta organización multitudinaria, un sentido común analítico acerca del valor productivo economicista y de las inclinaciones políticas partidarias (Battezzati, 2014) o de las relaciones y el ejercicio de poder hacia el interior (Rodríguez Blanco, 2011), a modo de vara que procura medir positividades en un fenómeno que -consideramos- muchas veces pone en juego elementos diferentes de lo útil y/o lo favorable. Promueve, más bien, objetos producto de una acción que no necesariamente se condice con lo necesario, sino que obliga a imaginar otras preguntas.

\subsection{Breve descripción de la escena. La experiencia del panorama público ${ }^{140}$}

El territorio elegido para el análisis consiste en un parque temático, un parque acuático y una construcción réplica del templo de Kalasasaya y las Puertas del Sol y La Luna ubicados en el barrio Tupac Amaru, dentro de Alto Comedero en la ciudad de San Salvador de Jujuy. Este emplazamiento se encuentra en un sector central del barrio en relación con las alrededor de tres mil viviendas construidas por la organización Tupac Amaru en un poco más de diez años.

De frente a la entrada del parque temático se presentan dos figuras de lobxs sentadxs con las camisetas de Gimnasia y Esgrima de Jujuy, celestes y blancas (cada uno de ellxs, en una androginia que escapa de cualquier evidencia generizante a priori). Los juegos del parque toboganes y hamacas- son figuras de cemento de dinosaurios, retomados de la película

${ }^{140}$ Aquí se utiliza panorama como concepto al que aluden Benjamin (2005) y Buck-Morss (1995) acerca del artefacto artístico del siglo XIX que artificialmente le permitía a un espectador observar a través de gigantescas obras circulares distintas escenas naturales, históricas, de ciudades, etc. El espectáculo era, aunque público, de experiencia individual. Y le permitía al sujetx trasladarse visualmente entre escenario y escenario de manera no secuencial. 
estadounidense 'La Era de Hielo', y duendes, del dibujo animado argentino 'Los peques'. También se encuentran como parte en el lugar pequeños autos antiguos de cemento y puentes de madera. Rodean el parque unos quinchos con techo de paja, mesas y algunos asadores. Además, se construyeron dos canchas de básquet y fútbol cinco en cemento, que a menudo se utilizan como punto de encuentro asambleario.

Detrás del parque temático se encuentra el parque acuático. Éste, que es el complejo de piletas más grande de la ciudad, está conformado por varias piscinas encadenadas que dan forma a la imagen del mapa de la provincia de Jujuy ${ }^{141}$. De un lado, se construyó una cascada con esculturas de pingüinos; del otro, dos lobos marinos de grandes dimensiones al borde de la pileta -réplica de los lobos de Playa Franca en Mar del Plata-. Además, la pileta posee barcos, toboganes y puentes. Estos barcos funcionan sobre todo en la temporada invernal.

Quizás, la imagen más imponente de todo el parque es la obra de aproximadamente $8.000 \mathrm{mts}^{2}$, réplica del templo de Kalasasaya de Tiwanaku, Bolivia. Este templo consiste en una pirámide escalonada de cemento, en cuya base superior se albergan las réplicas de los monolitos del Fraile y el Ponce, además de los rostros esculpidos en piedra a lo largo de muchas de las paredes de la obra; cada uno de estos elementos acorde con los del templo original. También en la cima del templo, se centraliza la Puerta del Sol con vista de frente a gran parte del barrio. Esta puerta apunta al Este, calculando el alba en dirección a las serranías de Zapla. A cada lado de esta puerta sobrevienen las figuras de Tupac Amaru y Micaela Bastidas, cada una de ellas esculpida

${ }^{141}$ Entre los anexos de la tesis se adjuntan capturas satelitales del barrio que ilustran claramente la fisonomía de la provincia en la pileta. 
mirando de frente a la parte más extensa del barrio.

Toda la obra se emplaza entre los primeros sectores del territorio construido. Limita con el estadio de fútbol José Gabriel, con la tercera etapa de viviendas, de alrededor de 20 construidas, con el Centro Cultural del barrio, con la escuela primaria Olga Arédez, con la obra del colegio secundario y, de espaldas, con un barrio ajeno a la organización, construido por el Instituto de Vivienda y Urbanismo de Jujuy, sobre el que se levanta un paredón a modo de barrera directa.

El conjunto de la obra no es considerado como una escena para una experiencia meramente contemplativa, sino que su cotidiana habitabilidad modifica de pleno su modo de ser, su forma y su incorporación a un régimen valorativo y de pertenencia con el entorno.

\subsection{Observaciones sobre la obra}

El exceso, la artificialidad y las ironías percibidas se presentan como terreno para recorrer de manera crítica la seriedad y la teatralidad satírica de un deseo común. La intensidad del parque puede hablarnos del deseo como voluntad ambiciosa y re-inventiva; atravesador de la formación colectiva, ni secreto, ni oculto, sin auras de vergüenza; un axioma radical reformulante (Guattari y Rolnik, 2006). Puede interpretarse como un deseo violento en tanto parece forzar a su medio.

Que cada parte parezca tanto premeditada como azarosa es coherente con un proyecto de prácticas resbaladizas, el cual, sin embargo, puede llegar a revelarse de manera más nítida en este tipo de expresiones visibles. 
También cabe aludir a la experimentación fáustica presente en esta y en muchas instancias movilizadoras de la organización, como imagen ambigua y movediza, deseante, a expensas de más, siempre desarrollista.

La presencia ubicua de la comunidad ${ }^{142}$ en el desarrollo de la experiencia del individuo es parte de una fórmula de existencia permanente en la organización y en cierta medida se ve consagrada en esta obra. Tiene la intención de abarcar -sin separar, ni fisurar- como un todo coherente el ocio, el trabajo, la espiritualidad y la política.

El estímulo por considerar cómo es lo que es ${ }^{143}$ esta obra genera preguntas que guiarán el resto del apartado: ¿Qué se cuestiona de la ciudad trazada al construir un templo indígena como epicentro barrial? ¿De qué manera y qué demandan en esta concatenación simbólica? ¿La Tupac se corre así del debate por la producción y la utilidad, por lo bueno y lo malo del hacer, cuando se crean materialidades espaciales en un registro diferente de la moral de las necesidades? ¿Nos habla de otra racionalidad económica en lo que decide hacerse? ¿O se condice con las vías en las que se renuevan las fórmulas del capital? ¿A qué se apela con esta materialidad si se la interpreta como una obra con excesos? $?^{144}$

${ }^{142}$ Cuando hacemos alusión a la comunidad referimos, más que a las formas clásicas en la que se presenta en la modernidad, como dispositivo disciplinante, presencia multiforme, anónima, de concebible peligrosidad; al esfuerzo de búsqueda de completitud como principio inmanente, interpretado a veces como reciprocidad; de cierta inaccesibilidad racionalista (Blanchot, 2002).

${ }^{143}$ Esta pregunta alude, casi a modo de cita textual, a un pasaje tan relevante como conocido del final del ensayo "Contra la interpretación" de Susan Sontag (2008).

144 Estas preguntas no guardan ninguna afirmación de antemano, sino que se entablan como incitaciones reflexivas que no concretarán respuesta resolutiva en este capítulo. 


\subsection{Replicar. La copia y la fantasmagoría ${ }^{145}$}

La mostración de los objetos se presenta al juego en términos de valor exhibible. Más que su uso o su posibilidad de cambio, se reactiva el placer desde un lugar diferente, espectacular, que no tiene que ver con la posesión, aunque sí con la experiencia de consumo.

La dislocación entre clase, posesión y consumo, quizás sea de los elementos más gravitantes para el análisis de la Tupac en su conjunto. La exhortación al consumo es convocada tanto como mito del progreso social más moderno; como haciendo de vía alternativa (o desviada) de los parámetros de pertenencia capitalista más recientes.

Este parque parece hacer culto a un tipo de consumo, al fetiche espiritual y a la promesa del acceso, traducidos todos en embellecimiento urbanístico y monumentalidad, como fórmula del mejoramiento social.

Lo colosal de la obra se vale de las decenas de réplicas que en términos de signos comportan, además de los vastos sentidos previos (y debido a las circunstancias en las que se hunden), indicios de transformaciones simbólicas para los elementos allí presentes. Parece mostrarse como esa necesaria restauración de una promesa histórica, a partir de una expresión de la espiritualidad y el capitalismo que en la relación sujeto-objeto equipara y profana símbolos de la más diversa índole (Berman, 2011; Buck-Morss, 1995).

Es la melancolía que provocan algunos de estos símbolos la que los hace emerger de manera

${ }^{145}$ Este punto está movilizado por lecturas acerca del carácter preeminente de la modernidad, como Berman (2011), Benjamin (2005) y Buck-Morss (1995). 
más visible en su actual acontecer como huella de la fragilidad de la cultura (Benjamin, 2005). Esta fragilidad se ve también expresada en la parodia que supone cada elemento imitado, al derivar sobre un nuevo sentido (disidente) del que hacía parte en un procedimiento original. Quien los enuncia, el contexto y el uso los refuncionalizan en un valor tangencialmente paródico.

\subsection{Indigenizar la ciudad ${ }^{146}$}

La réplica del templo indígena descripto podría reconocerse a prima facie como un desgaste ornamental de los signos (Rivera Cusicanqui, 2012), un forzado emblema a modo de alegato para la cohesión comunal, en razón de una complicidad inadvertida con cierta 'nostalgia imperialista' de época (Rosaldo, 1989), de lo que debió haber sido la historia del pueblo.

Se reconoce, sin embargo, que los sentidos normalizados de la ciudad de San Salvador de Jujuy se construyen aun narrados en términos de una figura de localidad ideal abonada y restituida por los elementos más visibles a partir de los cuales se caratula el delineamiento de identificación univoca pretendido por los sectores hegemónicos ${ }^{147}$. Esta configuración ideal se presenta fenotípicamente blanca (de ascendencia europea o, en menor medida, árabe ${ }^{148}$ ), argentina (en

\footnotetext{
${ }^{146}$ En este punto señalamos algunos argumentos contrastando perspectivas poscoloniales.

${ }^{147}$ Ya hemos delineado estas articulaciones hegemónicas locales. Podemos recuperar en esta instancia como parte de las escenas visibles que aportan a su constitución, entre otras, a la Fiesta Nacional de los Estudiantes (desfiles de carrozas, elecciones de reinas), las conmemoraciones anuales del Éxodo Jujeño, el símbolo deportivo del Gimnasia y Esgrima de Jujuy (el lobo jujeño), las celebraciones y peregrinaciones populares cristianas de la Virgen de Río Blanco y Paypaya. Además del Carnaval, en el que los sectores hegemónicos -rotulados como experiencia popular anual-se permiten hablar y habitar jolgoriosamente el interior no urbano.

${ }^{148}$ Lo blanco, como se percibe, se presenta como marca geopolítica.
} 
conflicto y negación con la proximidad boliviana), católica, gaucha heroica (coherente con el nacionalismo criollo del siglo XX) y con necesidad de lo urbano como contrapartida de aquel territorio/paisaje etnificado, patrimonializado y fronterizo, que suponen la puna y quebrada provinciales $^{149}$.

Así, la espectacularización de lo indígena en la ciudad puede percibirse, en cambio, como signo eficaz, ante una operación urbana por desindigenizar la ciudad y por etnificar el interior provincial. La presencia de este símbolo indígena no es ni ornamental, ni pintoresco, sino que puede trascender como elemento crítico interno, como presencia incómoda que habla a partir de elementos construidos concatenadamente en comunidad ${ }^{150}$. Lo que se dice, lejos del ventriloquismo global que intenta insatisfactoriamente representar a lo diferente, es voz y performación de aquellos que habitan la ciudad y que habitan este barrio. Y esa voz es un llamado a la imaginación, concretado en el paisaje ch'ixi (Rivera Cusicanqui, 2010).

Lo ch'ixi como metáfora qhichwa habla de la conjugación de elementos diferentes sin subsumir uno a otro, tejido de materiales opuestos que no se dan como fusión desproblematizada, sino como trama heterogénea, filigrana en la que coexisten tanto antagónica como complementariamente texturas diversas. Esta trama cheje nos permite considerar un tipo de territorialidad en la que se reconozcan figuras renovadas del hacer colectivo y un territorio

149 Esta conceptualización se hace basándonos sobre todo en lo ya trabajado por Burgos, 2014; García Vargas, 2010a; Ficoseco, 2007; Caggiano, 2005; Karasik, 1994; Belli y Slavutsky, 1994; entre otros.

150 En este punto, al hablar de comunidad lo hacemos configurando un sector de la población que en gran medida se ve conformada por sectores migrantes que, por un lado, se vieron forzados a 'drenar' las regiones de puna y quebrada como elementos ya fragmentados a partir de la operación crónica de confinamiento excluyente que marginalizó a los habitantes de esta región, tanto del proyecto político nacional, como del provincial; y, por otro lado, por procesos más recientes de vaciamiento de polos productivos empresariales en la zona de las yungas y los valles más próximos. 
resultado del proceso permanente de las formas organizacionales de regionalidad actual.

\subsection{Jugar. Los juegos del parque $\mathrm{e}^{151}$}

En parte Disney, en parte Fox, hechos en chapa y cemento, los juegos y las figuras prehistóricas podrían presentarse como tácticas de apropiación irreverente de símbolos de consumo y de prestigio.

Incluso parecieran burlarlos al emplazarlos como uno más de los pliegues especialmente materiales de la comunidad y la reciprocidad. De alguna manera parecen actuar y narrar los imaginarios globalizados neoliberales en una inteligibilidad otra, que podría no traducirse de entrada como fetiche mercantil, sino ejercer una producción ingeniosa por la cual en la misma operatoria por hacer propios símbolos formulados específicamente como emblemas eyectores del mercado se materialicen condiciones para vivir mediante una economía comunitaria del espacio. Los imaginarios de consumo parecen ser desafiados de lleno al hacerse acreedores de sus signos, performándolos propios en la copia ${ }^{152}$. Esta materialidad parece deslumbrar cierta potencia para exceder los imaginarios más simplistas de dominación cultural.

Esta escena no es armoniosa, ni complementaria con el capital, sino que puede abrir un camino

${ }^{151} \mathrm{La}$ intención en este punto es tratar de percibir distintos modos de comprender la experiencia del capitalismo contemporáneo.

${ }^{152}$ Dos interpretaciones al respecto. Primeramente, que la copia no puede reconocerse linealmente como parte del hiperproductivismo mercantil de época, sino que más bien es acción que difracta transformando (Haraway, 1999). Por otra parte, que la copia se corresponde con la pérdida de la singularidad de por sí dada en las condiciones artísticas contemporáneas y que el valor político de esta experiencia de exhibición es su modo de habitabilidad (Benjamin, 2003). 
aparentemente disfuncional (Segato, 2012). Si bien puede interpretarse como coherente con el carácter de la modernidad occidental, desde este occidente, al ser la ironía la que moviliza la obra, dado que la profanación de las imágenes sagradas del mercado resulta parte de los movimientos dialécticos inherentes a la readecuación permanente de la modernidad. En definitiva, como repite Berman "todo está preñado de su contrario" (2011: 8).

\subsection{Veranear. La pileta y las configuraciones de la inclusión ${ }^{153}$}

La plaza está rodeada de calles de tierra, por supuesto. La aridez y la dureza del suelo en Alto Comedero hacen que cada vehículo que circule deje un tendal de polvo que se cuela por las orejas y las narices. El gris de las escalinatas del templo indígena y el beige de los techos de paja en los quinchos, contrastan con los cuerpos de los duendes y los dinosaurios, en amarillo, rojo y naranja, pero sobre todo con el cemento pintado de celeste, con forma de bota que hace a la vez de pileta y de provincia.

'Veranee con la Tupac' manifiesta la pintada en los perímetros del predio del parque acuático. Esta leyenda no pretende ser conciliatoria. Si bien concede el terreno, invitando a compartir, lo hace sobre todo para sentar la evidencia de una actitud históricamente negada. Esto no es tanto el llamado a la caída de la breva para el que no recibía, sino el sojuzgamiento del que no compartía.

${ }^{153}$ En una misma línea con los puntos anteriores, este apartado se pregunta por la convivencia en el capitalismo, pero desde las tonalidades más específicamente locales. 
Es que esta pileta apunta a ser el pivote más revelador de una serie de imaginarios colectivos locales. Al menos dos reguladores de status de la región y la ciudad se pondrían en juego porque ir a la pileta y vacacionar en Mar del Plata ${ }^{154}$ (adonde nos trasladan esos lobos marinos) no son actividades para cualquiera.

Pero además se apela a la pertenencia: a la argentinidad $^{155}$ del lobo marino como imagen de la playa nacional y a la irreductible condición peronista que tienen los gordos símbolos del veraneo popular-obrero. Principio identificador nacional, los lobos marinos son también aspiraciones hasta ahora negadas: el ocio permitido para quien trabaja, veranear y vacacionar. Se denuncia al símbolo, pero, nuevamente, se lo hace propio. Se invita al veraneo pero se remarca a quién le pertenecería ahora.

Junto a los lobos se conforma una tríada simbólica en el parque acuático que hace imaginar un país: toda la provincia de Jujuy, como forma puesta en mapa para ser observada desde el templo; los lobos marinos que retrotraen a la costa rioplatense y al horizonte utópico obrero mencionado; y la última arista, que alberga a la aún más artificiosa presencia de los pingüinos patagónicos, cuya puesta al sol en los márgenes de la pileta y en este barrio es sólo interpretable en base a la apariencia monolíticamente alineada con un proyecto político venido de esos confines.

Toda esta exhortación al ocio zigzaguea permanentemente con las aspiraciones de pertenencia y los símbolos del auto-desarrollo individual y, en clave histórica nacional, con el desarrollo

${ }^{154}$ La ciudad costera se encuentra ubicada a dos mil kilómetros de San Salvador de Jujuy.

${ }^{155}$ Esta proposición de identidad homogénea nacional se utiliza de manera crítica, asumiendo la exterioridad obligatoria que requiere una conformación colectiva de este tipo. Advertimos que recurrimos a una articulación de la identidad en estos términos y a una expresión de este tipo, como muchas de las expresiones vertidas sobre este apartado, solo a nivel de movilización deconstructiva de dicha sentencia. 
económico de las clases populares trabajadoras.

\subsection{Mostrar. Derroche como exhibición ${ }^{156}$}

Cuál parece ser la cualidad más reconocida y valorada de este proyecto organizacional, sino la masividad de la obra en general, la gestionaria y la necesaria: la que 'otorga' condiciones de bienestar, fácilmente aprehensibles -el techo, la salud, la educación.

Sí, tanta imperiosa necesidad habitacional, aquí truncada por el gasto "improductivo". Decenas de miles de ladrillos apilados, consumidos, gastados. Desgaste ornamental. Incoherencia por el derroche de la producción. Sin embargo, posible potlatch alternativo local.

Entre el número, el gasto, la masa, la obra desmedida, no se percibe un aura de racionalismo envilecedor del esfuerzo, del desgaste o de la pérdida. Aunque existe un comportamiento agonístico, no parece ser el principal movilizador del derroche de materia. Existe una promesa de concreción de algo inconmensurable y ella parece ser la que moviliza la acción (Bataille, 1987).

Estos excesos son una afrenta a la moral de la necesidad por la que transita la experiencia comunitaria de estos sectores. Porque si como colectivo surgieron de la necesidad urgente, lo generado requeriría servir. A qué servirán entonces.

Es que la moral cristiana moderna no adscribe al gasto fastuoso público, no concibe el derroche

${ }^{156}$ En este apartado oponemos el contraste entre una lectura más "inmediata” y cotidiana local y una delirante exposición foránea para pensar en lo sacrificial como competencia hacia el prestigio y la imagen pública. 
como función social positiva. Quizás por eso no se construyó una iglesia frente a esta plaza, como sí se hizo en el resto de las localidades aledañas. Quizás porque estos excesos tienen otras razones y sentidos regionales, planteados desde una racionalidad económica diferente, mas no incoherente. Así como quien hace la invitación abierta para la fiesta de carnaval, para la pachamama en su casa, o aquel que vuelve al pueblo y ostenta los frutos de lo conseguido. Como quien invita a lo suyo demostrando no sólo que puede, sino que tiene de sobra. La 'propiedad positiva de la pérdida' (Ibíd.) tiene valor de reubicación jerárquica en el alarde de quien puede gastar. Y este es así un gasto logrado.

\subsection{Deshacer. El género y los cuerpos visibles ${ }^{157}$}

Pareciera no haber margen para la duda. La identificación por medio del fútbol echa mano al repositorio más clásico de los símbolos de adecuación al ideal y a la norma. En el caso local: el lobo es jujeño, el lobo representa y es todos los jujeños ${ }^{158}$ y el lobo es masculino.

Y así, la presencia de los dos lobos en réplica, parece un reaseguro de la estabilización de las figuras y los roles en y a través del fútbol. Aunque como se mencionó en un primer momento, a primera vista se hace difícil una distinción evidente del género de cada unx de ellxs. Hasta parece inquietante notar la presencia de una figura de apariencia femenina en torno al deporte, aunque ya de antemano en este contexto se acople a una discusión necesariamente más profunda

${ }^{157}$ Este punto se presenta a las claras con una intención interpretativa post-feminista, desde autorxs clásicas en esta línea como Butler (2008, 2005), Preciado (2007) o Platero (2009).

${ }^{158}$ Burgos (2014) presenta críticamente la manera en la que en las últimas décadas y hasta la actualidad, el club Gimnasia y Esgrima se erige como estandarte identificatorio clave de los jujeños y la manera, prácticamente catacrética en la que Gimnasia se hace Jujuy. 
acerca de la barrabrava conformada por integrantes de la organización, llamada 'La banda de la flaca' $^{159}$. Cabría pensar en la posibilidad de una rearticulación de género en los liderazgos clásicos en las hinchadas, aunque esta experiencia adscriba sin búsquedas de mayores fisuras al ejercicio más tradicional y virulento del aguante deportivo.

Podríamos imaginar que estxs lobxs se desdoblan haciendo gráficas las contradicciones permanentes entre las que se desarrolla todo el movimiento, entre la norma y la adecuación más jerárquica y los devenires más fronterizos. Si es un lobo varón contentaría a cualquier ojo heteromasculino: musculoso, de pectorales marcados y piernas fibrosas, atlético, de mirada feroz. Y si es un lobo mujer, qué hacer al respecto de la contextura física que presenta, considerando además que despliega pechos y cabellera larga, consiguiendo feminizar esa figura tan cara a uno de los elementos más eficaces del repertorio de sostenimiento identitario heteropatriarcal-masculino, tan férreo de la provincia.

Puede que esta mirada yerre de universal: el ojo asume primero a un masculino y da por sentado que la diferencia se establece en la operación feminizante del cuerpo. Parece construir una versión fantasmática de la mujer a partir de la imagen del varón.

${ }^{159}$ Cabe la mención de que como parte de las tareas de campo se acompañó varias veces a la Banda de la Flaca en partidos de Gimnasia. Desde los prolegómenos de reunión, asado, la llegada de colectivos con bandas e instrumentos al cantri -punto de encuentro de los barras-, el viaje en colectivos colmados que atraviesan Alto Comedero y la autopista hasta llegar al estadio 23 de Agosto, la entrada a la cancha, la revisión policial y los partidos, se siguieron como parte de la hinchada a fin de asimilarlo como una más de las lógicas y vínculos en torno de la organización. Se retoman los pormenores de estos momentos como parte de una comprensión más íntegra del colectivo. Sin embargo, la complejidad de un fenómeno de estas características al interior de un proceso ya de por sí multilateral y polifacético como es la Tupac Amaru requiere de una instancia de abordaje más detenida que lo que se puede mencionar en este capítulo. Es sin duda, una de las vertientes de interés abiertas a lo largo de esta tesis que pueden devenir en parte de una investigación futura. 
La elaboración paródica también puede imaginarse mediante la construcción de una feminidad con evidente potencia física, todo eso que no debe ser frente al canon estético y a las prácticas que se le requieren; virilidad y fortaleza en contra de la modelación cultural del género.

Podríamos también sugerir que la actitud de distorsión del femenino y el masculino en ambxs lobxs manifiesta que la forma extravagante se impone redefiniendo el contenido original; es decir, que en la enunciación masculina de la pertenencia futbolera, puede existir un guiño, una ruptura inadvertida de las fronteras hegemónicas del género, por la cual la paradoja se expresa en que la materialización más evidentemente masculinizante del parque (ese lobo jujeño), se estetice en una categoría de género aparentemente inválida: representacionalmente ¿lobx andróginx? ¿lobx trans? ¿lobx drag?

\subsection{Satirizar e ironizar. Reapropiación simbólica y apuesta camp}

Se puede pensar otro tipo de desbordes sensoriales y significantes trastrocando sentidos previos, convirtiendo una cosa en otra distinta. La conjugación espectacular que consiguen con el conjunto del parque transita tanto la ironía y la seriedad, como lo sombrío y lo festivo.

Se aprecia cuando se incorporan al privilegio del ocio moderno y lo satirizan; en la ritualidad esotérica del templo indio hecho para lxs coyas de la ciudad; en la androginia estilizante (y feminizante) del lobo, bastión del aguante masculino futbolero; cuando montan lo prehistórico, lo mitológico, lo mítico y lo peronista como parte de una misma esencia común.

El travestismo más elegante de los símbolos permite corromperlos cuando, ya siendo propios, 
la ironía de que lo sean hace verosímil la sátira. Y ahí, en la seriedad que comporta la ironía, yace la reescritura más crítica como forma de cuestionamiento social. Planteamos, un paso detrás de la institucionalización del devenir multitudinario, la búsqueda más delirante de los sentidos porque así parecen darse, a modo de expresión crítica cuando se manifiestan primariamente.

La valoración en estos términos, en este registro está dada por proponer otra lectura de los posibles, por no apegarse ni creerse de lleno ninguno de los bordes identificantes extremos de cada elemento, pero también porque cuando teatralizan al ideal, reconstituyen la demanda en deseo y en placer adquiridos.

La alusión a lo camp como parte de las reflexiones que clausuran parcialmente esta veta del análisis viene directamente inspirada de lo planteado por Sontag hace medio siglo, no como cese en la problematización de lo planteado en este apartado o de las estructuras fundamentales que definen a la Tupac, sino como otra vía de apertura crítica necesaria. El planteo de la autora refiere a un tipo particular de percepción del mundo y a una autoría provocativa. Transitamos en lo que aparenta ser un lugar que evidencia las posibilidades de un programa que promueve la explotación política de la alteridad como vía para la crítica y el empoderamiento político colectivo. Estas miradas parciales fueron puestas en los retazos de lo que podemos considerar como un constante devenir entre lo emancipatorio y lo conservador, como parte del despliegue permanente del movimiento. 


\section{DEMANDAS ÉTNICAS EN EL CONTEXTO MULTICULTURAL}

Al comenzar el himno nacional, todos los militantes de la Tupac se quitaron sus gorras y entonaron el himno, ambos brazos al costado, bien erguidos. Algunos miraban de reojo la manera en que los de al lado, de la Cámpora, lo coreaban futboleramente, vitoreaban y saltaban. (...) Más adelante, un nuevo cruce, pero ya más caldeado, se generó cuando los de la Tupac sostenían los cánticos de aliento militante, frente a un silencio casi general del resto de los presentes en la plaza, quienes escuchaban el discurso de Cristina Fernández de Kirchner; los de la Cámpora les pedían que se callaran para poder escuchar el discurso presidencial, pero ellos no se detenían. Notas de campo, 1 de marzo de 2015. Discurso de apertura de las sesiones ordinarias en el Congreso de la Nación. Buenos Aires.

\subsection{Presentación}

En este apartado proponemos considerar los términos en los que es posible representarse como colectivo indígena en el contexto simbólico del Estado argentino para, desde ahí, considerar la manera en que se 'etnifica' la experiencia para hacerla traducible en clave demandante. En cierta medida, es un ejercicio deconstructivo ${ }^{160}$ que parte de las imágenes que representarían un

160 "La deconstrucción, del tipo que sea, no es valiosa para exponer un error, ciertamente no el error de otras personas o el esencialismo de otras personas. La crítica más seria en la deconstrucción es la crítica de las 
repertorio de lo indígena a la hora de exigirle al Estado argentino. La intención es desandar parte de las estrategias que pretenden hacer inteligibles en demandas étnicas procesos experienciales de la alteridad.

La escena que construimos permite considerar el accionar de la Tupac Amaru para problematizarnos cómo se constituyen en la actualidad discursos en torno a lo étnico en el contexto federal; qué implicancias políticas conllevan esas construcciones; quiénes, cómo y a quiénes apelan esos discursos, esas imágenes, esas prácticas; para, así, discutir los límites y potencialidades que puede cargar este escenario de puesta en acción y negociación de sentidos acerca de lo indígena en el plano actual nacional a la hora de actuar y exigir ${ }^{161}$.

Para ello y para movilizarnos algunas preguntas acerca del tema, retomamos distintas imágenes de los 'Pueblos originarios en alianza con la organización Tupac Amaru' ${ }^{162}$ durante la reasunción de la presidencia de la Nación por parte de Cristina Fernández de Kirchner durante $2011^{163}$ y la marcha del bicentenario de los pueblos originarios ${ }^{164}$. Elegimos estos dos momentos puntuales por lo significativo de las fechas en cuestión, pero dichas performances pueden remitir a muchos otros momentos visibles de la Tupac en cualquiera de las manifestaciones públicas de

cosas que son extremadamente útiles, cosas sin las cuales no podríamos vivir, arriesgarse.” (Spivak, 1993: 4)

${ }^{161}$ En última instancia, también se puede considerar partes de este texto como un meta-texto inscripto en la reflexión acerca de la posibilidad discursiva y la intervención en el plano representacional. Es decir, una consideración ética acerca de etiquetar/asir.

${ }^{162}$ Existe una articulación entre un sector de las comunidades indígenas de puna, quebrada, valles y ramal jujeño y la organización barrial Tupac Amaru. Este sector dentro de la organización se identifica como contingentemente articulado.

${ }^{163}$ Se retoman fotografías recabadas en redes sociales oficiales y de militantes, noticias publicadas en medios digitales, información de la página oficial de la organización y material fotográfico generado en distintos momentos del trabajo de campo. Se hace un análisis interpretativo crítico de los materiales, considerando la pertinencia del contexto de surgimiento y la circulación de cada uno de ellos.

${ }^{164}$ Marcha federal durante la semana previa al 25 de mayo de 2010. 
los últimos años (apertura de sesiones legislativas provinciales y nacionales, celebraciones, ceremonias y rituales como el Inti Raymi o el día de la Pachamama, entre otras).

En el interés por lo inmediatamente visible es primordial rehuir, eludir la linealidad de la lectura más próxima. Se asume la sincronía de la escena construida como un fragmento que permite aprehender con intensidad un estado (siempre pendular), resultado parcial de una lucha simbólica permanente acerca de lo evidente o lo reconocible.

\subsection{Comunidad, organización y demandas al Estado}

Como ya hemos desarrollado, la organización barrial Tupac Amaru fue conformada inicialmente en la provincia de Jujuy a fines de la década de los ' 90 , a partir de las apremiantes necesidades de sectores urbanos marginales de la capital provincial. Nace como un colectivo similar a distintas experiencias a nivel nacional que tuvieron su mayor efervescencia a principios de la década. Algunos perduraron como marca de época del vasto movimiento social que pretendía obligar la necesaria reconfiguración de un sistema neoliberal desbordado por los límites a la ciudadanía que él mismo impuso.

Ésta, entre esas otras experiencias surgidas como resultado de un régimen económico-político excluyente, porta como uno de sus elementos particulares más destacables el hecho de hacer de la puesta en valor del indigenismo y el respeto por las culturas precoloniales una de sus demandas más relevantes. Así, a reclamos que exigen mayores posibilidades de acceso al empleo, a la educación formal (en todos sus niveles), al sistema de salud, a la vivienda digna, le 
suman demandas por derechos específicamente reconocidos para las comunidades indígenas regionales.

En la necesidad de habitar la vida, los instrumentos distintivos a los que se recurre para 'decirse' se cristalizan generalmente en categorías que segmentan cuotas de reconocimiento en el orden contemporáneo de políticas de identidad. Aquello que en estas coordenadas se reconoce como clase, etnia, nacionalidad, género y sexualidad son razones reconocibles que en el cruce transversalizan la experiencia humana haciendo de la posibilidad de su señalamiento, condición que genera consecuencias desiguales para la reproductibilidad de la vida. En otras palabras, podría decirse a modo de ejemplo inicial que el reconocimiento de mujer se traduce en condición de diferencia.

La igualdad como fórmula histórica ciudadana, como modelo formal apelable para la convivencia, se ha desenmascarado como sistema insuficiente al no bastar como promulgadora de una equidad material en las condiciones de la vida de las personas, sino que, mediante la justificación basada en la pretensión de homogeneidad, desconoce -promoviendo su exclusión del mapa de reconocimiento- a todo aquello que se devela como diferente. La diferencia se ve sometida a mecanismos materiales de exclusión, mediante la premisa de que aquello que no entre en la condición de igual (idéntico) es señalable y jaqueable en el tablero ciudadano (Femenías, 2013).

En cierta medida, preguntarse por las políticas de identidades es preguntarse, no por quién es qué, sino más bien que supone buscar cuáles son las trayectorias históricas, culturales y políticas que cimientan el qué para cada quién. Ahí parece yacer, obviado, el fundamento del derecho a 
qué según quién sea.

De entre las voces audibles, entre aquellas que son menos bajas $^{165}$, se distingue el diálogo que se establece entre Estado y colectivo demandante. Relación que obliga, primero, a identificarse -como un quién reconocible- para luego decir -en el modo en el que el Estado quiere escuchar (con el pretexto de entender) - qué se quiere, para, quizás, obtener lo que le correspondería según su condición existente. La posibilidad de conversación aquí planteada no debe tomarse a la ligera, sino procurando vislumbrar el peso de la consecución de dicho intercambio frente a la estrecha probabilidad de acceso a las estructuras abstractas del Estado.

De este llamado a la intervención estatal como fórmula surge un primer elemento para un análisis más exhaustivo que el que seguramente podemos pretender en esta primera instancia, dado por las preguntas: ¿cuáles son los términos en los que estos pueblos indígenas (o esta articulación de sujetos que se reconocen como pueblo y como indígenas) que se definen como milenarios, precoloniales, premodernos, le pueden exigir efectivamente (eficazmente) a la forma moderna del Estado nacional derechos (universales, igualitarios -y en ese sentido, homogeneizantes)? Y sobre todo ¿de qué forma se pueden leer esas demandas?

$\mathrm{Y}$ a partir de esto, ¿puede ser el esencialismo estratégico ${ }^{166}$ étnico una posible respuesta a demandas de otro tipo? ¿Y será esa la respuesta más conveniente? ¿O demandar desde ese lugar

${ }^{165}$ La noción de voces bajas, originalmente creada por Ranajit Guha, es retomada por Bidaseca (2011) para diferenciar en los niveles de intensidad entre las posiciones contrahegemónicas o alternativas, entre aquellas que no son fagocitadas, representadas o traducidas.

${ }^{166}$ El término esencialismo estratégico fue acuñado por Spivak (2011 [1988]), originalmente en su conocido ensayo ¿Puede hablar el subalterno? Fue retomado y sometido a revisión y crítica por la misma autora en los años subsiguientes. 
los corre y corrige como movimiento transformador?

En este sentido, se presenta al esencialismo estratégico como concepto ${ }^{167}$ y estrategia política, que supone un reconocimiento por parte del subalterno en razón del discurso del opresor y "como si de una esencia se tratara" (Femenías, 2007: 113), a fin de una identificación (justamente) estratégica y funcional con el propósito de construir un sujeto auto-afirmativo que aproveche la contingencia en la lucha por un horizonte reivindicatorio colectivo y emancipatorio más diferenciado.

En este caso, e identificando el conflictivo derrotero del término en las últimas décadas (Mattio, 2009), lo más conveniente sería imaginar las potencialidades y consecuencias de esta vía de reconocimiento esperando que se propicie un desbalance del concepto en favor de lo estratégico, más que de la 'esencia'. Un “error necesario" (Butler, 1993: 309) que debe ser permanentemente cuestionado a sabiendas de aquello que excluye de antemano una (re)presentación en nombre propio.

Más allá de esto, como propuesta de visibilización colectiva, como estrategia, podría presentarse como opción posible y efectiva en tanto politiza y articula a sectores diversos, con demandas diversas, con cosmovisiones, saberes y trayectorias diversas.

167 Decimos concepto, pero no en clave académica. "Una estrategia le cabe a una situación, una estrategia no es una teoría" (Spivak, 1993: 4). 


\section{3. “¿La Tupac junto a la presidenta Cristina!”168. Ciudadanía y representación}

indígena

Retomaremos una imagen para iniciar con el análisis más específico en escena. La fotografía en cuestión (ver en Anexo) fue tomada por una militante de la organización en diciembre de 2011, durante los actos de reasunción de la presidencia de Cristina Fernández de Kirchner en las calles de la ciudad de Buenos Aires, y fue publicada en la red social Facebook. Tomamos esta imagen como punto de partida, no por ser extraordinaria o atípica, sino en definitiva como un grano de arena de un médano de secuencias semejantes corroboradas a lo largo de los últimos años.

La fotografía muestra de frente la pancarta: 'Pueblos originarios. Jujuy - Argentina', con una wiphala $^{169}$ a cada lado. Detrás, cientos de banderas de la Tupac Amaru llevadas por cientos de personas identificadxs con las remeras blancas y gorras beige de la organización. Se ve también a tres hombres tocando percusiones y flautas ${ }^{170}$. Lo que nos interesa retomar es el recuadro derecho de la imagen en donde se encuentran dos mujeres jóvenes. Ambas visten vestidos tipoy $^{171}$ de colores, por arriba de unos jeans, remeras, zapatillas y gorras.

De esta manera se articulan iconografías de pueblos indígenas de distintas regiones. La wiphala, más identificada con los pueblos andinos, sobre todo aymaras; los tipoy, vestimenta de

${ }^{168}$ El nombre del álbum de Facebook del que fue recogida la fotografía para este análisis es "La Tupac junto a la presidenta Cristina!" (Disponible https://www.facebook.com/silvana.lanchez/media_set?set=a.2694753484777.182592.1134762092\&type =3 visto por última vez el 9/6/15).

${ }_{169}$ La whipala es una bandera de cuarenta y nueve cuadrados con siete colores. Es usada por algunos pueblos andinos identificados sobre todo con la región de los pueblos aymara del Tawantisuyu.

${ }^{170}$ Identificables como instrumentos para el pimpim, un baile típico de los pueblos indígenas wichíes.

${ }^{171}$ El tipoy es un vestido de origen español impuesto a las mujeres guaraníes después de la colonización. 
regiones más bajas, de pueblos guaraníes; un baile como el pimpim, etc. Todos estos símbolos, que en la actualidad se vinculan a una iconografía originaria son en alguna medida una traducción colonial erosionada de los pueblos indígenas. Esta articulación icónica convive, por otro lado, con otros símbolos de la organización Tupac Amaru. Además de la presencia del líder indígena en sus banderas, también se encuentran imágenes de Eva Perón y el Che Guevara, respectivamente, símbolos del populismo y socialismo latinoamericano del siglo $\mathrm{XX}^{172}$.

Podemos reflotar la idea de que adherir a una articulación estratégica de distintas comunidades, de distintas regiones, que conviven con distintos contextos y que sostendrían distintas demandas, puede comprenderse como una estrategia funcional en la que la unificación política supondría en alguna medida, empoderamiento comunal. No sin ignorar la obvia pregunta acerca de qué es lo que la conformación colectiva necesariamente omite o excluye como parte de su configuración interna. Es decir, asumir que la promesa de la articulación visible implica el riesgo de la omisión de elementos del mapa.

Más allá de esto, con respecto a las dos mujeres en la fotografía nos preguntamos ¿Por qué fue necesario sumarle a los otros símbolos una vestimenta como el tipoy encima de sus prendas? ¿Se indigenizaron de esa manera? ¿Son ellas así un símbolo indígena? ¿No lo eran en jeans y zapatillas? Y así ¿se presentan como un símbolo de resistencia o como una teatralización de la condición 'originaria'?

Más aún, la noción de lo originario hace peso sobre la construcción de la mujer que se propone.

\footnotetext{
${ }^{172}$ Ambas corrientes políticas que reclaman una subversión del sistema estructural del Estado en vistas a extender los derechos ciudadanos de amplias capas sociales. Todas estas categorías se reconocen por supuesto en términos de un léxico común a los Estados modernos tal como los concebimos.
} 
La "carga de la representación" (Mercer, 1990, cit. en Yuval-Davis, 2003: 17) recae sobre las mujeres porque culturalmente se presume que a ellas les corresponde la reproducción (cultural y biológica) de lo ancestral y lo originario. En esta imagen son portadoras visibles de la tradición ${ }^{173}$, así como históricamente se ha asumido sobre las mujeres el sostenimiento y fortalecimiento de identidades colectivas (étnicas, raciales, de nación) y su autenticidad (Curiel, 2011; Dimri, 2012).

Es que de esta forma, y bajo la condición de 'originarixs', no pueden sencillamente ser presentadas como coetáneas, contemporáneas y cercanas (¿urbanas?). Pareciera ser más sencillo representarse como se los requiere un sistema y una nación que lxs incluye, pero recortadxs y condicionadxs por estos emblemas. Emblemas con los que se reconocen sus demandas, demandas que se vinculan en gran parte a la tenencia del territorio y a la preservación natural ${ }^{174}$, demandas por lo pronto invariablemente rurales, invariablemente internas (profundas, casi escondidas).

Indígenas ¿urbanas? de jeans y zapatillas tendrán otras demandas, diferentes. Atravesadas por su condición indígena, por su condición de jóvenes y por su condición de mujeres, pero no se reconocerán como demandas indígenas, porque esas parecen estar indefectiblemente dirigidas

173 Es significativo considerar como, si bien en la Tupac en general son las mujeres cholas y vestidas con tipoy las que encabezan las marchas y Mama Quilla es la figura 'materna' que guía espiritualmente los rumbos de la organización, durante todos los años de trabajo de campo para esta tesis el contacto autorizado, representante y voz oficial de los pueblos originarios sea un hombre, Jorge Ramos. Un punto más para la consigna en la distancia planteada entre figura permitida y voz autorizada.

174 Cuando hablamos de las demandas, retomamos escenas específicas con pedidos expresados: primero, en el petitorio presentado en la Casa Rosada al final de la marcha de los pueblos originarios durante los festejos del Bicentenario argentino (2010) y, como ejemplo entre distintos proyectos de ley, el presentado por diputadxs representantes del $\mathrm{FUyO}$ en el que se pide que se involucre a las comunidades originarias en cualquier medida administrativa, legislativa o productiva vinculada con la minería, el turismo, la tierra, el territorio, la educación o el medio ambiente. (Diario Libertador Hoy, 9 de abril de 2014). 
al contexto territorial rural y natural. Lo indígena, como categoría identificatoria, es complejo y resbaladizo ${ }^{175}$, tanto para quienes pretendemos caracterizarla, como para quienes buscan reconocerse en ella ${ }^{176}$.

Lo que sí queda en evidencia es el daño que puede provocar socavar los límites de lo que supondría la cuestión indígena al subsumirla a una sinonimia indígena-campesino, como ha sucedido en países como Bolivia a mediados del siglo XX, ocluyendo las variantes culturales tan cambiantes que se ponen en juego en razón de la variabilidad espacial en las que ocurren (Stefanoni, 2012).

Los polos ciudadanía/indigenidad - urbanidad/naturaleza oponen un contraste destinado a violentar, cercenando en una sustracción espacial toda una serie de sentidos acerca de quién puede habitar y manifestarse visiblemente como parte de un territorio. Se juega con lo temporal, al remitir veladamente lo originario a lo estático, lo pasado, lo residual. Concebirlo como presente implicaría reconocer una cohabitabilidad radical en la que se asuma la actualidad y urgencia de sus necesidades; concebirlo como urbano, implica una convivencia próxima con un sector que a nivel nacional parece seguir siendo parte de un imaginario de lo lejano y lo foráneo. "El 'pueblo originario' afirma y reconoce, pero a la vez invisibiliza y excluye" (Rivera

175 Un antecedente y ejemplo de ello es la búsqueda "acertadamente trunca" que propone Agustina Paz Frontera (2013) al preguntarse por las identidades mapunkies y la evidencia de la dificultad para encasillar la alteridad en términos de nitidez identificable. Su trabajo deviene en crónica que acompaña la experiencia deslindada de las urgencias por definiciones y categorizaciones.

176 “¿En qué casos los derechos que persigue la identidad 'para sí misma’ se convierten 'en sí mismos’ en un medio de administrarla? ¿Cuándo la identidad articulada a través de los derechos se convierte en producción y regulación de sí misma a través de la ley y la burocracia? ¿Cuándo se convierte el instrumento legal en un instrumento de regulación y el reconocimiento político en un instrumento de subordinación?" (Brown, 1995: 99). 
Cusicanqui, 2010: 60).

Aquí no se cuestiona meramente la manera en la que se (re)presenta el colectivo que demanda, sino que se consideran las condiciones y limitaciones con las que se encuentran ante el repertorio discursivo de época a nivel federal.

Este relegamiento de lo étnico a lo lejano y residual, espacial y temporalmente, es determinante en sus efectos políticos al subsumir en categoría de minoría a un sector de la sociedad con potencial hegemónico en la región. Más allá del estimado peso demográfico 'real' de los indígenas en el territorio argentino ${ }^{177}$, hay una operación de eliminación imaginaria que los desplaza y los suprime temporal, espacial y numéricamente. Tanto la producción de discursos académicos y políticos ${ }^{178}$ acerca del tema, como la reproducción mediática de tales imaginarios, la invisibilización de su presencia en el contexto metropolitano ${ }^{179}$, en la agenda mediática y en

177 Atendiendo a las complejidades que supone un auto-reconocimiento identitario y todos las cargas que se ponen en juego sobre adscripciones de este tipo presentamos, a modo ilustrativo, las cifras del último Censo Nacional de Población, Hogares y Viviendas (2010): la población auto-reconocida indígena o descendiente de pueblos indígenas u originarios asciende a 955.032 habitantes, lo que corresponde a casi un $2,4 \%$ de la población total en el territorio nacional argentino. Por su parte, en la provincia de Jujuy, la población auto-reconocida indígena asciende hasta un 7,8\% del total provincial. Fuente: INDEC.

${ }^{178}$ Según ensayistas como Ernesto Laclau, por ejemplo, cuyas teorías hacen a cimientos fundamentales de muchos de los argumentos de esta tesis. En su análisis acerca de la política argentina en el marco de la reelección de Cristina Kirchner como presidenta de los argentinos, remarcó que las demandas de los pueblos originarios "no son centrales para la estructuración de la política" (Bullentini, en Página/12, 2/10/11).

${ }^{179}$ La configuración del ser nacional, emanada a partir de una idealización compleja con orígenes rioplatenses que se presumen europeos, nubla conflictos raciales en los que se bloquean a alteridades étnicas a partir del señalamiento trastocado en clave de nacionalidad. Así, brotes xenófobos en conflictos como los experimentados durante las tomas de tierras en el Parque Indoamericano en la ciudad de Buenos Aires en el año 2010, apuntalan argumentos que extranjerizan, nacionalizando como ajenos a aquellos que racialmente no se adecuen a lo que supone idealmente un ciudadano porteño (Caggiano, et. al., 2012). Otro ejemplo de ello es la manera en que inmediatamente se vinculan los talleres textiles en la ciudad de Buenos Aires y el conurbano a la inmigración transfronteriza. Este tema es íntegramente tratado en el análisis acerca de la mixtura ch'ixi entre los talleristas y el rigor laboral y económico al que son sometidos como parte de una 'bolivianidad' armada en aras de instancias de ejercicio de poder 'argentino' (Colectivo Simbiosis, Colectivo Situaciones, 2011). 
la generación de políticas públicas, colaboran a disminuirlos o aminorarlos.

Aún más, esta misma operación es llevada adelante por un movimiento social (con mayoría de militantes indígenas urbanxs) que busca en el indigenismo (de corte rural) un relato para disputar incluirse y pertenecer en el plano ciudadano visible nacional.

Es importante traer a colación nuevamente la práctica de presentación tumultuosa con la que lxs militantes de esta organización habitualmente se apropian de los espacios públicos de las ciudades al momento de exigir ${ }^{180}$. Más allá de esto, al negociar así las formas de representación (en tanto minoría originaria) contribuyen a imaginarios que colonizan desde el discurso visual multicultural, subalternizando la diferencia. Porque un tipo de multiculturalismo digerido ha funcionado como articulador de la trama de relaciones que reconoce en 'cuotas' de autoafirmación y reconocimiento, pero deja liberado a los límites de esta estructura las posibilidades de efectiva transformación y reconfiguración de sus condiciones de existencia (Delfino, 1998). El agenciamiento se ve coartado por los límites discursivos preexistentes que condicionan las posibilidades de acción sólo hasta los márgenes previamente definidos por la agenda de lo plural en términos de reconocimiento.

Estas formas estereotípicas étnicas son funcionales al sistema que las presenta, que les da ese lugar para el surgimiento de lo visible ${ }^{181}$. Lo reconocible a través de símbolos estereotípicos

${ }^{180}$ Durante el trabajo de campo etnográfico, tanto en San Salvador de Jujuy como en la ciudad de Buenos Aires, se relevaron decenas de manifestaciones en la vía pública, en reclamo y en celebraciones, acampes en reclamo y otra serie de expresiones de su presencia que hacen parte en una práctica permanente de disputa por espacios públicos patrimonializados o simbólicamente restringidos para los sectores relegados.

${ }^{181}$ Surgimiento en el plano visible de la agenda que le permite serlo. Hablar de una efectiva genealogía de la etnia como elemento de reconocimiento y encuentro histórico implica un recorrido diferente del que tratamos cuando hacemos referencia a la visibilización en sus términos actuales. 
permite identificarlxs en la diferencia, y así lo identificable mediante "simplificaciones de rasgo fijo" (Femenías, 2007: 70) arma el panorama de lo representable en los términos en los que lo hegemónico lo permite. Pero lxs indígenas ¿sólo pueden hablar desde esos símbolos?

Hablar de la distancia entre representación y experiencia es hablar tanto de los límites que supone la traductibilidad audible en términos identitarios, como de las condiciones para la materialización corporal, vector de dichas demandas. Porque las marcas étnicas, racializadas, atraviesan y van más allá en las experiencias cotidianas que lo que supone esta escenificación de lo indígena ${ }^{182}$. Efectivamente, las marcas indígenas condicionan relacionalmente sus experiencias; pero la licencia representacional de la alteridad sólo les permite presentarse a partir del discurso que contingentemente los contiene. La representación de la etnia (en esta imagen, en estas manifestaciones) sólo se esgrime y se narra a sí misma dentro de lo imaginable, lo permitido desde el discurso hegemónico de lo multicultural como lo diverso otro que es sencillamente identificable.

La base de lo que demandan no necesariamente tiene razones identitarias, pero aunque probablemente tenga más que ver con materialidades históricas o prácticas comunes, queda claro que se enarbola en tanto que un tipo de identificación colectiva. Lo que se disputa es la manera de resistir de forma multitudinaria, reapropiándose de los métodos epocales de

182 Entre los cuestionarios de las entrevistas realizadas durante 2010 se incluía una pregunta a lxs militantes que residían en el cantri acerca de procesos de exclusión vividos. Una de las respuestas más comunes fue haber sido excluidos por 'negros' (que funciona como categoría de clase racializada). En entrevistas previas (llevadas adelante durante 2009), sobre todo entre mujeres del interior de la provincia que militan específicamente en el área de Pueblos Originarios, ellas afirmaron que su incorporación a las líneas de la Tupac Amaru tenía sobre todo que ver con el acceso al alimento (por medio de los bolsones) y la posibilidad futura de trabajo y de vivienda. El derecho a los títulos de las tierras no fue mencionado por ninguna de las entrevistadas. 
enunciación.

Sus experiencias quizás no encuentran elementos de inteligibilidad posible. En términos de lenguaje audible, parecieran no tener voz ni en el discurso académico más paternalista, ni en un culturalismo romántico, ni en la lectura social que excluye desde el mismo gesto en el que nominaliza, mucho menos en la política pública que cristaliza fragmentariamente o en cualquier otra instancia reconocible como ejercicio de poder, sino que está más ligada a un vivir indecible y sin embargo experienciable, una pelea que se da en la génesis previa a su codificación, desde los términos mismos en los que se plantea y se encarna tal experiencia.

La forma de 'pueblo originario', en este sentido, supondría más allá de una historicidad en tanto pueblo con algún tipo de patrimonio común -más que como originario-, como un pueblo emergente que, si tiene en común algo, son biografías marcadas por los trazos de la alteridad como factor determinante en sus trayectorias.

Nuevamente, en esas trasgresiones materializadas en la experiencia no sencillamente reconocible es en donde se pueden encontrar los elementos posibles para una nueva y diferente narrativa de codificación representacional. Y en este sentido, acordamos con Butler acerca de la necesidad de relocalizar la traductibilidad de la experiencia:

La tarea no será asimilar lo indecible en el dominio de la decibilidad para albergarlo allí, dentro de las normas de dominación existentes, sino hacer pedazos la confianza de la dominación, mostrar cuán equívocas son sus pretensiones de universalidad y, a partir de ese equívoco, rastrear en la ruptura de su régimen, una apertura hacia versiones alternativas de universalidad que se forjen a partir del 
trabajo de traducción mismo. (2011b: 183)

En definitiva, no se trataría de elucubrar un nuevo modo de particularismo que los aloje como parte del mismo sistema, sino más bien, y más de raíz, una reconsideración en la base hegemónica misma, que considere a la fluctuación de las diferencias como competencia inherente del sistema. La búsqueda por alguna instancia de descolonización encuentra en los regionalismos críticos (Spivak, 2012) quizás las mejores condiciones. Sin embargo, se siguen exigiendo cambios dentro de los márgenes de la historia y el poder de dominación de una soberanía nacional, cuando quizás son rastreables como expresiones más posibles dentro de poiesis menos abstractas.

\section{4. La marcha de los pueblos originarios en el bicentenario}

Durante mayo de 2010, en el marco de los festejos por el bicentenario argentino, desde el área de pueblos originarios de la organización Tupac Amaru se organizó una marcha de pueblos indígenas a nivel nacional que confluiría en la ciudad de Buenos Aires. Para ello, se organizaron tres columnas de manifestantes: una por la región NOA -que se desplazó desde La Quiaca y recorrió las provincias de Jujuy, Salta, Tucumán, Santiago del Estero, Córdoba, Santa Fe y Buenos Aires-; otra del NEA, que comenzó en Misiones y Formosa, y recorrió Corrientes, Chaco, sumándose a la columna NOA en Santa Fe; y una tercera, la columna Sur que recorrió Mendoza, Neuquén, Río Negro y el sector sur de la Provincia de Buenos Aires.

La intención de esta marcha, acordada en conjunto entre referentes de distintas comunidades 
a nivel nacional, proponía entregar un documento con una posición en común por parte de los pueblos para el establecimiento de un Estado Plurinacional, el cumplimiento de la ley de relevamiento territorial de comunidades indígenas, la restitución de tierras a estas comunidades y los títulos de propiedad de territorios comunitarios. Esta marcha se propuso como cierta intención de réplica histórica del 'Malón de la Paz' jujeño ${ }^{183}$.

A continuación se desarrollan algunas reflexiones respecto de los puntos principales de las demandas presentadas en la marcha del bicentenario, poniéndolas en relación con las implicancias que cada una de ellas supone en el contexto nacional. Hacemos hincapié principalmente en dos puntos: la plurinacionalidad como estrategia de reconocimiento en un marco global multicultural y el reclamo territorial rural por parte de un movimiento de carácter mayoritariamente urbano.

\subsection{Pluralismo y multiculturalismo}

En la referida marcha del bicentenario de los pueblos originarios se exigió la instauración de un Estado Plurinacional. Dicha configuración estatal promueve modificar de raíz el elemento opresor de vigilancia, de imposición de autoridad y de aquella soberanía que se define a través de la delimitación de eso que no es: por la negación, por lo que deja fuera. El Estado-Nación,

183 "En mayo de 1946 los arrendatarios de la puna jujeña marcharon hacia la Capital Federal para exigir los títulos de propiedad de las tierras que ocupaban, reclamando el derecho a la tierra. El «Malón de la Paz», como se lo llamó, recorrió los más de dos mil kilómetros que separan a Jujuy de Buenos Aires con la esperanza de que el nuevo presidente diera curso a sus reiteradas demandas. Cuando llegaron a Buenos Aires fueron saludados por Perón desde los balcones de la Casa Rosada y trasladados al viejo Hotel de Inmigrantes, donde permanecieron hasta que fueron devueltos hacia su provincia sin haber obtenido sus demandas" (Lobato y Suriano, 2003: 76). 
con una única nación, fuerza una versión de la cultura que históricamente ha definido el relato nacional argentino. La violencia con que se dominó (militarmente) ${ }^{184}$ y hegemonizó (culturalmente) el territorio a través del programa unificador para la conformación de una única nacionalidad suspendió las posibilidades de reconocimiento y nubló las resistencias del sector amplio que quedó y perdura definido como minoría en el territorio.

La noción de pluralismo parece menos estática, esencializante y ontologizante de las culturas por poner "el énfasis en sus portadores y en la identificación que respecto de ella(s) sienten los individuos involucrados" (Femenías, 2007: 44). La plurinacionalidad como demanda presentada al Estado exige la representación y el reconocimiento institucional, suspendiendo (idealmente) las opresiones que el colonialismo interno como práctica supuso a modo de sistema de gobierno. En este rediseño estatal se apela programáticamente a la perduración de las naciones originarias (con un posible filo esencialista) y al reconocimiento de los conflictos históricos como parte de las condiciones de existencia de un sector de la población no englobado dentro de la Nación, como piso hacia la mejora en las condiciones de vida actuales. Estas consideraciones se basan en los programas estatales de las dos versiones de pluralismo estatal ya existentes -Bolivia y Ecuador- a las que apelan en el documento presentado en la marcha del bicentenario argentino.

184 Uno de los cánticos de la marcha que analizamos dice: "Acaso porque soy coya no tengo oportunidad...vamos Tupac, que todo el pueblo quiere gritar... (...). Eso jamás, lo que nos hicieron van a pagar, milicos van a sufrir, milicos van a llorar, hoy día van a pagar todo lo que han hecho con mi pobre dignidad". Por una parte, convivimos con las marcas del avasallamiento histórico por parte de la milicia en el período fundacional del Estado sobre las comunidades indígenas y la utilización de indios y afrodescendientes en las distintas guerras nacionales. A eso, le sumamos hoy -entre diversos conflictos presentes en el ejercicio violento de poder 'cívico'-militar- bajo la premisa de la seguridad nacional, conflictos de frontera en los que se visibiliza un sistemático rechazo violento basado en la racialización sobre los residentes fronterizos y migrantes latinoamericanos y, considerando la indigenización de la pobreza urbana, una criminalización del marginal en las ciudades. 
Estas demandas por pluralidad se someten a discusión en discusión en un panorama global multicultural. El multiculturalismo más frecuente aparece como pretensión refundacional de las búsquedas igualitarias y supone un 'reconocimiento' que se queda estanco al esencializar a un unx con un otrx ${ }^{185}$, diferente - categorizado por medio de una nominación catacrética ${ }^{186}-$, que más bien se hibridarían o asimilarían en el marco de sistemas modernos como piso universal de reconocimiento de derechos entre diferentes.

Creer que superar los argumentos del igualitarismo por medio de la celebración de un culturalismo relativista por cuotas resuelve los conflictos de la alteridad es modificar sin transformar nada de hecho. Concepciones alternativas ya presentes en el plano nacional como el 'buen vivir' o 'vivir bien' ${ }^{187}$, en el marco del reconocimiento multicultural, son necesariamente- conflictivas al intentar cohesionarlas con un trasfondo latinoamericano y argentino neodesarrollista y extractivista que desde hace unas décadas se vale de distintos pasajes institucionales para seguir controlando y recolonizando las acciones y formas políticas posibles de diversos sectores al interior de los Estados. Su utilización retórica en ciertos contextos parece un discurso mal habido por parte del capitalismo contemporáneo para terminar

185 "El otro como una sombra de sí mismo. Este otro, inaccesible, es sin embargo representable, caracterizable y nombrable en los términos del uno. Deberíamos de considerar que, en todo caso, el llamado a llenar el vacío de lo inasible no proclama 'que se deje hablar al otro por sí mismo', sino que "apela a un 'llamado' a lo 'completamente distinto' (totu-autre, como opuesto al otro que es una consolidación de sí mismo) para 'volver delirante esa voz que es la voz del otro en nosotros'" (Spivak, 2011: 59). El encomillado interno en la cita corresponde a Derrida, 1994.

186 La catacresis como performación que obliga a encolumnar la heterogeneidad en términos argumentales (Aguilar Giménez, 2012) significados sólo sobre el poder sin sentido del lenguaje posicional (De Man (1984), cit. en Aguilar, 2010). Figuras que funcionan inapropiadamente; el uso de un nombre adecuado para abarcar algo que no se corresponde puntualmente con él (Butler, 2007). "'Tu llámame así, pero lo que yo soy elude el alcance semántico de cualquier esfuerzo lingüístico semejante por capturarme"' (Butler, 2011a: 20). Un objeto sin referencia, al que no le cabe ningún término existente, bajo la premisa de que es constitutivamente innombrable (Laclau, 2011).

187 Suma qamaña en aymara, sumak kawsay en quichua. 
fagocitando gestos comunitarios alternativos de potencial transformador al institucionalizarlos. El buen vivir (cuya traducción más adecuada sería vida en plenitud) asume un vínculo armonioso entre la humanidad y la tierra, en términos más holísticos que la concepción occidental de tierra/recursos naturales. En el marco federal se torna improbable imaginar una opción por el buen vivir frente al incentivo por el consumo y la propiedad por un lado, y, por otro, con el sostenimiento y avance del extractivismo y el monocultivo acelerado, como parte de las consignas estatales para el progreso.

Este tipo de debates acerca del bienestar, el desarrollo, el progreso y la ética de producción, de consumo y de posesión son viables de todas maneras en este tramo histórico, en Latinoamérica (García Linera, 2012) y en distintos polos globales (Hardt y Negri, 2012). Reformulaciones medulares del sistema de reconocimiento y reproducción ciudadana son posibles en el terreno de puesta a crítica de las fórmulas históricas de los Estados-nación. Parece más posiblemente señalable la porosidad que deja ver las falencias y los quiebres de las formas jurídicas que sostienen ciertos tipos de regímenes; no en detrimento de la institucionalidad para la convivencia, sino en razón de invertir elementos otrora opresivos, como parte de la constitución de un nuevo mapa de reivindicaciones. En este plano hasta parece hacerse posible proponer nuevas figuras descolonizadoras en una nueva institucionalidad.

\section{6. Indígenas ¿rurales?}

En lo que respecta a los reclamos territoriales rurales presentados en la marcha sucede algo similar a lo que ocurría con la presentación de las imágenes étnicas en las otras manifestaciones. 
Como grupo en posición subalterna, en la forma en que se presentan a sí mismos y a sus demandas, sólo logran reconocerse dentro del discurso que los contiene y les da márgenes para exigir. Así, se manifiestan exhortando un reconocimiento territorial rural, espacio que, a nivel nación, ha sido constituido como parte de la diferencia de la que venimos hablando. Si estos son los sujetos de la alteridad construida por la modernización, occidentalización y cristianización, su espacio como condición para la subalternidad es indefectiblemente el rural.

Lxs militantes de la Tupac Amaru son en su amplia mayoría urbanxs, pertenecientes a los sectores más densamente poblados de la provincia. Pero su discurso acerca de lo indígena indefectiblemente pegado a lo rural ejerce una clausura que excluye lo indígena del presente en el ámbito urbano en el que ellos experimentan sus vidas. Sus demandas los performan, en tanto ellos se construyen a sí mismos como indígenas sólo en presencia del territorio rural. Se escapa de las manos nuevamente qué es lo que podría definir una identificación indígena. En cierta medida, se clausura la posibilidad de pertenencia al presente urbano en los términos en los que la gran mayoría de los militantes de hecho reproducen sus experiencias.

Que los derechos indígenas en boga se presenten en relación a la preservación natural nos pone en cuestión: por un lado, culturas que, se asume, se vinculan con la naturaleza con otra racionalidad, lejos de la ficción occidental que continúa dividiendo naturaleza de cultura; y, por otro, en la invariable lectura occidental de los derechos exigidos, la preservación -acompañada de un paradigma ambientalista de época ${ }^{188}$ - parece dejar en segundo plano al sujeto, parece

${ }^{188}$ Ambientalismo que en definitiva refiere a la distribución de bienes materiales y las valoraciones significativas que se ponen en pugna. 
relegar o inclusive anular a quien efectivamente demanda esos derechos.

El intercambio entre los representantes de las comunidades y Cristina Fernández en audiencia genera un cruce en el cual la presidenta lxs 'invita' de manera permanente a ser "inteligentes" para reconocer que no son el único colectivo subalterno a nivel nacional discriminado (los compara con las mujeres y la comunidad LGBT), para aceptar los "beneficios que ha traído la modernidad" (señala los celulares de cada unx de lxs presentes) independientemente del origen étnico, para reconocer la necesidad de un Estado extractivista en los contextos actuales (alude para ello la experiencia del Estado boliviano), para "negociar" y "pivotear sobre transformaciones y cambios sin perder la esencia", ofreciendo brindar "mejores condiciones de vida que no solamente se logran estando en el monte" 189.

En este sentido, sostener la existencia y presencia indígena como mayoritariamente rural o campesina, ambientalizar la lucha indígena (Leff, 2006), expresar las demandas en términos del hábitat rural, del territorio en esos términos, los ubica en un debate que hegemónicamente se presta a tergiversar las cosmovisiones indígenas; en detrimento del sujeto, en favor de una manera de concebir como preponderante al territorio; un tipo de territorio, ecualizado en gramáticas ambientalistas.

Lo aquí planteado no busca ir en detrimento de las luchas de los indígenas rurales, ni plantear una polarización entre categorías y efectivas experiencias indígenas urbanas y rurales, sino que más bien se observa la manera en que al espectralismo crónico en el que se desarrolló la historia

${ }^{189}$ Extractos encomillados con expresiones textuales de audios registrados en la audiencia entre quince representantes de los pueblos indígenas y la presidenta al final de la marcha. Audios incluidos en anexos. 
indígena a nivel nacional, se le aporta una nueva dimensión en la gama de no reconocimientos, parte de un esfuerzo iterativo de desconocimiento o, inclusive, anulación.

Por un lado, se hace necesario considerar que si bien existe un marco para la figura visible (en el Estado y en la Tupac), no existiría en el plano ontológico un margen en el cual habitar una ciudadanía más cabal que comprenda lo indígena. No se habilita la posibilidad de existencia por fuera de los discursos hegemónicos mencionados acerca de qué es lo indígena a nivel federal. El esbozo de la demanda parece obviar la existencia más próxima, coetánea y co-territorial de muchxs sujetxs.

Por otra parte, cuando se asume la alteridad y la diferencia como parte 'a incluir' en el mapa multicultural ${ }^{190}$ y no como razón de refundación del territorio mismo que podría asumirla, se corren los riesgos no sólo comunes a las distintas vías para licuar y digerir imágenes como parte del sistema, sino también, del filo esencialista que promulga el requisito de inmutabilidad histórica -con el coste opresivo- en razón de la pervivencia de la tradición.

Lo paradójico de los diálogos interpuestos en el plano público (con la interpelación hacia el Estado, con las estrategias de visibilidad escénica, y la respuesta estatal) es la ambivalencia inherente en dicho intercambio. El desdoblamiento permanente al que nos somete la Tupac, como cualquier experiencia movimientista de este tipo, opone, sin requerimiento coherente, la sustancia de la regeneración, como del aplanamiento en la esencia. Es decir, aparenta contener intrínsecamente las tácticas para la resistencia posicional; una suerte de reto para una poiesis

\footnotetext{
${ }^{190}$ En otro de los pasajes del intercambio con la presidenta, y en una renovada alusión por el crisol nacional, ella les aconseja pelear "como argentinxs" más que "como indígenas", aludiendo a que lo más valioso de la nación es el respeto por "la libertad y la igualdad, pero para ello no hace falta ser diferentes".
} 
mediante la identificación, como es la reivindicación del ser (indígena) en contextos en los que el auto-reconocimiento afirmativo de este tipo parecía y parece algo sustraído a partir de los embates violentos hechos a su nombre. Que ese ser sea la actualización de la nominación o la habilitación para una renovada forma de experiencia depende en gran medida de que esta apuesta implique romper con las pretensiones de literalidad última a las que parecen seguirse anudando. 


\section{MARCHA DEL ORGULLO. REPERTORIOS DE VISIBILIDAD DE LA DIVERSIDAD}

\subsection{Presentación}

La noche del 28 de junio de 2013 se generó la primera manifestación masiva en la ciudad de San Salvador de Jujuy que respondió a las consignas del orgullo ${ }^{191}$. Así, miles de personas convocadas por la organización Tupac Amaru dieron forma a lo que fue la primera marcha del orgullo en Jujuy en un marco de estas dimensiones. Hasta ese momento, si bien habían existido numerosas manifestaciones con consignas LGBT a lo largo de los últimos años -aunque exclusivamente en el ámbito capitalino de la provincia- en general no se había logrado reunir a más de una veintena de personas en cada una de estas movilizaciones previas.

La marcha del 2013, también llamada Marcha de la Dignidad, fue impulsada por el área de Diversidad de género, conformada al interior de la misma Tupac Amaru. Esta área es un proyecto de nucleamiento que llevaba hasta ese momento no más de tres meses de conformación estable. Desde ya, cabe establecer el contraste entre la tecnología de visibilidad que supone la Dignidad, respecto de la más habitual consigna por el Orgullo. Aunque ambas son auto-

${ }^{191} \mathrm{Si}$ bien desde hace unos años este tipo de marchas son conocidas como marchas del orgullo LGBTIQ u orgullo a secas, en la difusión previa por parte de la organización se refirieron a ella como Mega marcha del orgullo gay. (Disponible en http://www.tupacamaru.org.ar/nota.asp?wVarID=1495 visto por última vez el 8/6/15). 
afirmaciones, parece necesario rescatar la manera en que se optó por una consigna de menor identificación directa con la 'causa' LGBT y, en cambio, se aludió a una expresión más comúnmente propuesta y escuchada en el ámbito de la Tupac Amaru ${ }^{192}$.

El repertorio de esta marcha se condijo con muchas de las expresiones antecedentes a nivel nacional y global. Este tipo de acciones de visibilidad responden a lógicas relativamente estabilizadas en el marco global de reconocimiento político de las diversidades sexuales. Sin embargo, el análisis en el contexto local requiere de consideraciones coyunturales que lo vuelven un elemento plausible para intentar renovar preguntas acerca de la traducción política de las corporalidades y las subjetividades, la dislocación de las normas espacio-temporales urbanas locales, las ciudadanías sexuales, en el cruce con las demandas de pertenencia local, de clase, de género, étnicas, etc.

Y una vez más, nos lleva a la crítica por al menos dos vías que se sostienen a lo largo de toda la investigación: los términos en los que la traducción identitaria puede llegar a constreñir la experiencia; como así también la manera en que la elaboración agente se vuelve un elemento propositivo y regenerativo de la situación de lxs sujetxs.

${ }^{192}$ La noción de dignidad es a menudo usada entre los materiales de difusión de la organización, prácticamente desde sus orígenes, presente en vídeos que relataron a lo largo de todos estos años los avances y logros en el sector sanitario o en el acceso a vivienda. Por otro lado, y a modo alusivo, cabe la mención a la anécdota de principios de los ' 90 acerca de la resolución del nombre de la primera marcha llevada a cabo en la ciudad de Buenos Aires, para proponer una referencia posible en común con la situación local: "César Cigliutti, actual presidente de la CHA y uno de sus mejores amigos (Jáuregui murió el 20 de agosto de 1996 a causa del sida), recuerda que en las reuniones previas Carlos no estaba del todo seguro de usar para la marcha la palabra *orgullo* 'La palabra orgullo era muy fuerte en esa época. Nadie hablaba entonces del orgullo gay-lésbico, y al principio Carlos pretendía que usáramos otras palabras, como dignidad o libertad. Aunque enseguida entendimos que hablar de orgullo implicaba confrontar con esa vergüenza que la sociedad heterosexista quiso imponernos por ser gays, lesbianas y travestis" (Lennard, en Página/12, 08/11/09. Disponible en http://www.pagina12.com.ar/diario/sociedad/3-134924-2009-11$\underline{08 . h t m l}$ visto por última vez el 20/08/15). 


\subsection{Políticas de la identidad y registro de la diferencia}

Respecto de su carácter de modalidad global, hemos observado que cuando se trata de cualquier registro de la diferencia (no sólo sexual), las lógicas constitutivas del capitalismo tardío remiten a una cierta política de la identidad, mediante la cual cualquier hecho cultural parece pasible de ser remitido, integrado y asimilado al sistema global de identidades (Delfino y Forsatelli, 2012). Las masivas marchas del orgullo bien pueden considerarse como ejemplificadoras de esta situación.

Más allá de la pérdida posible cuando se traduce en términos identitarios ${ }^{193}$, una apuesta performática como tecnología de visibilización resulta potente en su posibilidad de poner en cuestión el carácter restrictivo y ficticio de cualquier orden de géneros, de cualquier orden del deseo. Como manifestación política de visibilidad y de interpelación al orden establecido que utiliza como única herramienta la presencia de los cuerpos, la marcha del orgullo resulta -tanto hoy como en sus inicios- una performance de importante potencia política.

Como punto de partida parece necesario tener en cuenta dos cuestiones. Por un lado, se puede asumir a la marcha del orgullo como estado de excepción de las normas espacio-temporales en ciertos contextos ${ }^{194}$, una apropiación por parte de sujetxs no previstxs o no legitimadxs para

193 "Las criticas queer y transgénero dirigidas a las políticas de la identidad gay y lesbiana han mostrado que la identidad homosexual no puede ser considerada como una 'exterioridad pura', a partir de la cual sería posible construir un 'paraíso universalmente deseable', sino que nos hallamos siempre en 'culturas situadas', cuyos límites no podemos dejar de interrogar, culturas en proceso atravesadas transversalmente por múltiples relaciones de poder. Lejos de ser una utopía incontaminada, la homosexualidad se vuelve el nuevo rostro de la normalización identitaria" (Preciado, 2007: 121).

${ }^{194}$ Esta es una analogía de lo planteado por Preciado (2010) quien distingue a Playboy como una producción arquitectónica que viene a reconfigurar las lógicas espaciales, el género y el sexo a través de una heterotopía que altera la forma y función de cada uno de ellos hasta ese momento de la historia moderna. 
ocupar ciertos espacios de la ciudad, resultando un elocuente elemento desnaturalizador.

Tanto los procesos vitales de la reproducción de la experiencia, como su configuración geográfica suponen distribuciones ordenadas de roles y lugares, regulaciones sobre los comportamientos valorados como legal y/o moralmente adecuados para cada ámbito. Esto no supone solo la admisión tácita por parte de los conciudadanos (como diseminación de una red discursiva basada en gradaciones del silencio sobre la sexualidad), sino que mediante la urbanidad y la arquitectura (con instituciones sociales y dispositivos de control) históricamente se ha moldeado el carácter de cada territorio a partir de la imposición de estatutos para la circulación y la visibilidad permitidas ${ }^{195}$ (Sennet, 1997; Figari, 2009; Park, 1999). El espacio social es un espacio sexualizado y sexualizante, configurado por el género y programador de su desenvolvimiento cotidiano.

Ante esto, bajo una apariencia festiva y carnavalesca en las performances del orgullo se quebrantan momentáneamente algunas certezas acerca del binarismo de género, el conservadurismo sexual ${ }^{196}$ y los tránsitos del deseo ${ }^{197}$. Se trata de teatralizar ese deseo y proponer otras consignas para la libertad sexual, atravesando los códigos morales concebibles

195 “Antes sí, nos discriminaban mucho [a] las chicas. No podíamos, nos metían presas porque andábamos con nuestras parejas. (...) O porque a mí me miraban antes, yo con otras parejas que tenía antes, antes que me junté con ella, nunca he andado, o sea, yo iba adelante y ella por atrás. $\mathrm{O}$ en las reuniones yo estaba acá y ella allá. O nunca salir de la mano, nunca andarnos mostrando" (Obrera-militante, entrevista de diciembre de 2010).

196 "Si verdaderamente hay que dejar un espacio a las sexualidades ilegítimas, que se vayan con su escándalo a otra parte: allí donde pueden reinscribir, si no en los circuitos de la producción, al menos en los de la ganancia. El burdel y el manicomio serán esos lugares de la tolerancia" dice Foucault (2014: 10) para considerar la manera en que se insularizan históricamente prácticas sexuales que quedan a la deriva de la moral burguesa.

${ }^{197}$ Es acuciante a este punto la distinción entre deseo e identificación, la primera como huella de la itinerancia para la modelización de las subjetivaciones en recursos como la representación y la identidad. Cuando en este apartado hablamos de deseo, lo hacemos considerándolo una fuga previa al momento discursivo de reconocimiento. 
en torno a la distribución política de los espacios y discontinuando la razón disciplinaria de los géneros en la ciudad (Ficoseco y Gaona, 2014).

Por otro lado, puede considerarse la concreción de esta marcha como arena de exhibición de identificaciones sexuales en el cruce con clases, racializaciones, etnicidades, edades y nacionalidades que no necesariamente coinciden con las categorizaciones más fácilmente aprehensibles o aceptables por parte del orden de género y sexualidades dominante, inclusive frente a la fórmula hegemónica de las sexualidades disidentes: sujetos de cierta pertenencia de clase, con acceso a ciertos consumos, de figuras estéticamente valoradas, con un nivel educativo alto.

Así como se arremete contra las lógicas de las configuraciones sexuadas del espacio local, se embiste también contra la modelización de las figuras LGBT dentro de un registro normalizante que las fagocita y convierte en una nueva instancia de visibilidades comercializables y de tendencias jerarquizantes al interior del movimiento. Así nos referimos a la configuración de una forma hegemónica del sujetx LGT (sin una entera asimilación de figuras bisexuales), con características de distinción jerarquizante por sobre otros sujetxs, lo cual suprime cierta capacidad articulatoria que supone la diferencia como valor.

La apropiación de las tecnologías de visibilidad por parte de sectores empobrecidos, de origen indígena, del interior del país o por parte de inmigrantes, de corporalidades de valor estéticamente degradado en el sistema mercantil, es una afrenta también contra el propio colectivo. Putxs que, encima de pobres, están orgullosxs.

Las condiciones de desigualdad y de subalternización a partir de la pertenencia a sectores de 
clase socio-económica baja, la inequidad a partir de la racialización de la etnia o la nacionalidad, la exclusión por el género o por la edad y la desafiliación institucional, como parte de las trayectorias de lxs sujetxs en la marcha en Jujuy, obligan a abrir la escena haciendo visibles los límites políticos y simbólicos de aquel sujeto que se asienta en las relativas ventajas de la celebración trivializada de las diferencias permitidas como parte del paisaje multicultural. La tensión se establece entre el uso político de la diferencia y entre aquella construcción que convive en la segmentación estratégica de particularidades como parte de los circuitos del consumo ${ }^{198}$.

Esta marcha no puede dejar de considerarse en torno de otras condiciones que operan entre las desigualdades del marco local, en los que la diferencia sexual se entreteje con las demandas por parte de los manifestantes acerca de una serie de situaciones en común, como la inaccesibilidad a la salud, al trabajo, a la educación, a la contención institucional y familiar, al rechazo público de la mostración y a toda una serie de factores que, violentamente, hablan del conservadurismo cultural heteronormal y patriarcal y de la implicancia que la condición sexual tiene sobre las demás instancias.

En la sumatoria de todas estas facetas con las que se encuentra la apropiación discursiva de una marcha por la dignidad y el orgullo dentro de esta coyuntura, consideramos relevante someter a crítica dicho auto-reconocimiento y su performance, a partir de la base de que

198 Se pueden considerar, a modo de ejemplo y como parte de los mapas de poder al interior del movimiento LGBT, la segmentación de la oferta gay friendly en el turismo y el comercio, el auspicio de un número importante de marcas y empresas en diversas marchas del orgullo o las ofertas de consumo que se encuentran en torno a la constitución del segmento comercialmente reconocido por la sigla DINK (double-income, no kids: doble ingreso, sin hijos), que hace alusión a parejas de clase media-alta, con formación profesional y que viven en zonas urbanas con acceso diferenciado a servicios. 
mostrarse orgullosxs es derivado de la necesaria diseminación de instancias de ocultamiento y sojuzgamiento sobre las conductas y los deseos. El procedimiento confesional que supone declararse orgullosx hace peso de ambos lados: es una de las escenificaciones libertarias más recurribles para performarse, agenciarse y auto-presentarse; pero hace parte y refuerza la condición de necesidad de 'salirse del closet' como una revelación infinita en la experiencia confesional (que produce expectativa y garantiza la insatisfacción) ${ }^{199}$.

Sin embargo, el gesto performático tiene doble función. El de la demanda más evidentemente 'política', de la consigna de género y sexualidad que se concatena con las demandas permanentes ya señaladas de la organización; y el de la remoción simbólica que actúan los cuerpos sexualizados públicos -en este registro relativamente disidente de la sexualidad, diferente de otro tipo de mostraciones públicas que operan imponiendo modelos de sexualidades hegemónicas. De la espectralización en la que la mayor parte del tiempo se ven obligados a habitar la vida, se vuelcan a la teatralización y espectacularización más flameante en razón de gesto político.

199 "Convencionalmente, unx sale del closet (y sin embargo, ¿qué tan a menudo se da el caso de que "salimos" cuando somos jóvenes y sin recursos?); así que salimos del closet, pero ¿para ir adónde? ¿a qué nuevo espacio sin límites? ¿la pieza, el estudio, el ático, el sótano, la casa, el bar, la universidad, o algún nuevo lugar cerrado cuya puerta, como la de Kafka, produce la expectativa de aire fresco y luz al que nunca se llega? Curiosamente, es la figura del closet la que produce esta expectativa y la que garantiza su insatisfacción. Porque estar 'afuera' siempre depende hasta cierto punto de estar 'adentro'; gana su significado solo dentro de esta polaridad. Por lo tanto, estar 'afuera' debe producir el closet una y otra vez para mantenerse 'afuera'. En este sentido, el afuera solo puede producir una nueva opacidad; y el closet produce la promesa de una revelación que puede, por definición, no llegar nunca. ¿Es para lamentar este infinito aplazamiento de la revelación de 'lo gay', producido por el acto mismo de 'hacerse visible'? ¿O este aplazamiento de lo significado como valioso, un sitio para la producción de valores, justamente porque el término adquiere una vida que no puede ser, nunca puede ser, permanentemente controlada?". (Butler, 1993: 309) 


\subsection{Contextualización histórica de la consigna del orgullo}

La fecha elegida para la primera marcha en el marco de la Tupac Amaru corresponde al día internacional del orgullo LGBT, fecha que conmemora el llamado Stonewall riot. Este hecho acontecimental, una serie de disturbios derivados de la represión policial neoyorquina durante 1969 en bares gay, marca el hito fundacional de las luchas modernas de ciudadanía sexual en occidente. El hastío por las habituales prácticas de hostigamiento y persecución policial en el barrio de Greenwich Village generó una serie de manifestaciones por parte de la comunidad gay, lesbiana y trans durante los días venideros y estos eventos quedaron circunscriptos en la historia como el punto de partida de un nuevo tipo de acción militante en favor del reconocimiento de los derechos de la comunidad LGBT (Belluci, 2010). Así, se estableció dicha fecha en el calendario internacional para las acciones celebratorias y de pugna política en favor de la ampliación de las libertades sexuales, supresión de las opresiones sobre las sexualidades y el auto-reconocimiento en clave de Orgullo.

Año a año se fueron replicando las manifestaciones de este tipo a lo largo de las capitales globales y ya para el año 1992 (23 años después de la primera manifestación en Estados Unidos) se concretó la primera marcha del orgullo en Argentina (en la ciudad de Buenos Aires), con la apuesta demandante carnavalesca como la conocemos en la actualidad.

Sin embargo, el derrotero de la colectivización LGBT en el contexto nacional se remonta al menos a dos décadas y media antes, con grupos como Nuestro Mundo (1969) o el Frente de Liberación Homosexual (1971), que a su vez agrupaba a una decena de colectivos con un número menor de militantes. La primera noticia de un colectivo fuera del ámbito porteño data 
de 1975, con la Agrupación Homosexual en Tucumán (Perlóngher, 2008). El paralelismo de estos grupos con la historia nacional reciente los ubicó permanentemente tratando de asimilarse y de introducir algunas de sus consignas en el marco de lucha más amplio de los partidos políticos. Siendo rechazados por el ala izquierdista del peronismo durante principios de los ' $70^{200}$, apartados también por las izquierdas $\operatorname{troskistas}^{201} \mathrm{y}$ anarquistas, perseguidos públicamente por el peronismo más conservador de la época y convocados al exterminio ya desde meses previos al golpe cívico-militar de 1976, el sostenimiento de las luchas se vio violentamente truncado por el accionar conservador, machista y fascista de ese período ${ }^{202}$.

Se hace relevante esta deriva en los intentos por la incorporación a los movimientos políticos tradicionales, cuando se la pone en contraste con la incorporación de dichas consignas a los nuevos movimientos sociales durante la última década ${ }^{203}$.

Para el retorno democrático se pone en pugna una redefinición del carácter de las sexualidades y sus luchas políticas. Nos referimos a dos modelos que parecen contrastarse, con la dictadura como bisagra. Por un lado, "una política deconstructiva que expulsa toda posibilidad de una noción fuerte de identidad en favor de una performance contestataria y siempre cambiante" (Rapisardi y Belluci, 2002: 200). 'La loca', como lo define Perlóngher (2008), se contrasta con

200 Tanto Perlóngher (2008), como Rapisardi y Belluci (2002) hacen alusión al cántico militante: "no somos putos, no somos faloperos, somos soldados de FAR y montoneros".

201 O el comunista, que lo identificaba, en palabras de Fidel Castro, como una 'aberración' contrarrevolucionaria.

202 "A la distancia, la tendencia del FLH a la hiperpolitización puede leerse como una postura delirante; cabría analizar, empero, si una sociedad que es capaz de pergeñar dictaduras tan monstruosas no hace que, necesariamente, cualquier planteo mínimamente humanista -como el reclamo de una mayor libertad sexual- tienda a convertirse en un cuestionamiento radical de las estructuras socioculturales en su conjunto" (Perlóngher, 2008: 84)

${ }^{203}$ Así como la Tupac Amaru cuenta con su área de Diversidad de género, también lo hacen otras agrupaciones de importante peso nacional como La Cámpora, Kolina o Miles. 
la modelización de una identidad gay, más asentada sobre una actitud de normalización inclusiva, que en definitiva termina por subsumir en una masa homogeneizada -aunque jerarquizada - a toda una serie de experiencias subversivas y de fuga. Del otro lado, y con la conformación de nuevos colectivos, se abre un plano de disputa política trazado por la autoafirmación y la lucha en clave de derechos humanos y derechos civiles, con la Comunidad Homosexual Argentina (CHA) como organización emblema y Carlos Jáuregui, como su alma máter (Bellucci, 2010). Así también se termina de afirmar el camino conjunto entre los movimientos feministas y los de liberación sexual (Tarducci, 2014).

La crítica por el solipsismo blanco de clase media del nuevo modelo conformado sobrevino, frente a lo cual, respuestas de organizaciones como la CHA en la época fueron "la homosexualidad es una sola"204 (Rapisardi y Bellucci, 2002: 202).

El Sida como problemática trascendente en la sexualidad, consigue derivar de la moralidad a la salud las nociones de riesgo, cuidado y temor, promocionando así el ocaso del reflujo de las sexualidades disidentes como potencias radicalmente disruptivas. $\mathrm{Y}$ así, parece concretarse definitivamente la epifanía foucaultiana del dispositivo de la sexualidad como regulador disciplinario. El pánico hace volcar a la homosexualidad nuevamente (como en sus orígenes) a las figuras médicas.

Este parece ser uno de los motivos por los cuales, en una comunidad además abatida por los

${ }^{204}$ Afirmaciones de este tipo se condicen con los relatos acerca de los distintos grupos de concienciación y experiencia compartida de lesbianas de la época pre e inmediatamente post-dictatorial, acerca de la operatoria invisibilizadora de los grupos lesbianos, tanto al interior del feminismo, como de los colectivos gay de la época. Si bien comúnmente se hace mención al grupo Safo de lesbianas como parte del FLH, al día de hoy no existen registros documentales, ni siquiera una mínima identificación de al menos una de sus integrantes (Tarducci, 2014; Chejter, 1996). 
embates de la enfermedad, para 1996 se modifica la fecha de conmemoración designada para la marcha anual en Buenos Aires. Así, se traslada al $1^{\circ}$ de noviembre de cada año en coincidencia con la fecha de la primera edición de la Revista Somos de $1973^{205}$ (Bellucci, 2010).

La marcha del orgullo en Buenos Aires se convirtió, partiendo desde sus orígenes cuando marchaban un centenar de personas hasta hoy en día, en uno de los eventos públicos de mayor convocatoria año a año en el país.

En el contexto más reciente, el debate y aprobación de las leyes de Matrimonio igualitario ${ }^{206}$ y de Identidad de género ${ }^{207}$, en 2010 y 2012, respectivamente, produjeron sobre la población en su conjunto ${ }^{208}$, un impacto cultural de gran envergadura a partir de debates, polarizaciones y exposición de roles y actores en escena; y, al interior de los movimientos LGBT, una instancia de cristalización de los rumbos políticos que habían encaminado dominantemente las demandas colectivas, traduciendo las luchas de género y sexualidades en regulaciones para un modelo propicio de vinculación (la familia) y de circunscripción físico-subjetiva (una identidad autoreconocida unívoca, traducida nuevamente al binomio). La avanzada en los mecanismos necesarios para la habilitación de una experiencia habitable de los cuerpos (Butler, 2005) por

${ }^{205}$ La revista de difusión del Frente de Liberación Homosexual que fue la primera producción dedicada a la comunidad LGBT en Argentina, editada entre 1973 y 1976.

${ }^{206}$ Ley 26.618. De matrimonio civil. Sancionada por el Senado y Cámara de Diputados de la Nación Argentina el 15 de julio de 2010. Promulgada el 21 de julio del mismo año.

${ }^{207}$ Ley 26.743. Sancionada por el Senado y Cámara de Diputados de la Nación Argentina el 9 de mayo de 2012. Promulgada el 23 de mayo del mismo año.

208 "Yo, por ejemplo, acá cuando vine no sabía nada de la noción del lesbianismo. Y después yo veía chicas que coqueteaban entre chicas y yo decía 'qué raro, chica contra chica'. Me quedaba shockeada, no podía creer qué pasó. $\mathrm{O}$ chango contra chango. Y acá en la Tupac se ve eso. Chu qué raro. Ahora más con esta ley aprobada, hoy en día se ve que todos están ahí agarrados entre todos". (Obrera-militante, entrevista de noviembre de 2010). "Si vos sos lesbiana ya es: 'eh tortugona, eh lechuga'. Cuando es alguien afeminado, ya todos los machos van: 'eh que puto'. (...) Y lo que pasó ahora, aceptan. Ponele a la mujer ahora se la trata igual que al hombre. (...) Y por el sexo también, la parte de los matrimonios gay, que algunos lo aceptan, otros no aceptan" (Obrera, entrevista de octubre de 2010). 
parte de al menos una instancia del Estado y el reconocimiento legal de los vínculos afectivos y filiales tiene un peso de magnitud insoslayable en la materialidad de la experiencia colectiva.

Ya a esta altura, las últimas ediciones de la marcha en la ciudad de Buenos Aires, convocadas por más de treinta organizaciones, superan año a año las 250 mil personas, en un desfile que va habitualmente desde la Plaza de Mayo hasta el Congreso de la Nación.

Para el Censo nacional de 2010, la población total del departamento Manuel Belgrano, en donde está localizado San Salvador de Jujuy, comprendía un total de 265.249 habitantes ${ }^{209}$. Fueron diez mil quienes se convocaron en el casco céntrico de la ciudad para consagrar así la primera marcha del orgullo masiva que registre la historia de la provincia, en una manifestación que se vio imbuida de toda esta acumulación histórica que da lugar a la posibilidad de este tipo de escenificaciones. Las características de la marcha jujeña apelaron en buena medida a una mixtura entre los desfiles tradicionales del orgullo, las manifestaciones festivas de la Tupac en la vía pública y los condimentos de los recursos de otro tipo de eventos celebratorios locales.

\subsection{Disputa con los símbolos hegemónicos locales}

En ánimo de intentar abarcar de la mejor manera lo que supone una manifestación pública del tipo de la marcha del orgullo, con la exposición de corporalidades alternativas a las normas dominantes respecto de aquellos cuerpos habilitados en el contexto jujeño, se hace necesaria una antesala respecto de las maneras en que se reponen a menudo los discursos legitimantes de

${ }^{209}$ Fuente: INDEC. 
este orden.

Como ya vinimos construyendo hasta este punto, se podría elaborar una especie de tipificación de las características ideales de las imágenes jujeñas, expresadas en este caso, en tipos de cuerpos y de identidades de género. Esas identidades locales hegemónicas como idealización devenida en norma portan la premisa fundante de operar en tanto regulación sexualizada y sexualizante.

Como hemos planteado antecedentemente, imágenes que flotan con carácter relevante en la constitución de esta pretendida identidad conllevan, entre otros elementos, la construcción de ideales varón-mujer, constatados en buena medida en el calendario de eventos públicos jujeños, donde se pueden destacar como los más relevantes la Fiesta Nacional de los Estudiantes ${ }^{210}$ (FNE) y la conmemoración por el Éxodo jujeño ${ }^{211}$ : el gaucho urbano que conmemora la fecha patria del éxodo, montado en un viril caballo que desfila por el centro de la ciudad; la mujer joven de características fenotípicas europeizantes que quiere ser elegida reina de los estudiantes, que inviste la feminidad y el pudor de la nobleza; ambos, el varón y la mujer, entregados a la fe católica en las celebraciones de las Virgen de Río Blanco y Paypaya (patrona de la ciudad).

Podemos intentar observar a contraluz de este repertorio de imágenes y cuerpos legitimados como auténticos portadores de estas identidades jujeñas dominantes, algunos de los ejes

210 La Fiesta Nacional de los Estudiantes se celebra anualmente en Jujuy en el mes de septiembre, habitualmente coincide con el inicio de la primavera. Al respecto, ver Ficoseco (2007).

211 La conmemoración por el Éxodo Jujeño es quizás el principal estandarte simbólico político de Jujuy, en el que se destaca la participación heroica del pueblo jujeño en la lucha independentista nacional. Se convierte en demanda, no sólo por la heroicidad y por la comunidad del pueblo, sino, sobre todo, por la pertenencia a la nacionalidad argentina, permanentemente en conflicto por la proximidad geográficocultural con Bolivia. Al respecto, ver Gaona (2014c). 
temáticos elegidos por la Tupac como articuladores o aglutinadores de sentido en la marcha del orgullo.

El evento consistió principalmente en un desfile por calles del casco céntrico de la ciudad en el que, de entre miles de personas identificadas en su gran mayoría por carteles que señalaban las distintas localidades concurrentes, se abrieron paso carrozas alegóricas, comparsas artísticas, percusiones y tambores.

El desfile se parecía por momentos a los corsos de los carnavales más habitualmente identificados con las zonas del ramal y los valles jujeños, en donde cada segmento de la marcha se presentaba como una comparsa distinta, algunxs con trajes al estilo lamé blanco con bailes coreografiados, otrxs en trajes de lentejuelas, con plumas y boas bailando ritmos murgueros como en las llamadas comparsas artísticas corseras-, otro segmento con una enorme bandera con los colores del orgullo, drag queens y drag kings ${ }^{212}$, algunas máscaras, algunx gatubela, unx mujer maravilla, unx ángel, algunx disfrazadx de lobo con un arlequín azul y blanco en la cabeza, acompañadxs de los bombos, tambores y platillos por parte de diferentes bandas de música identificadas con sombreros pintados con los colores del arco iris. De cada lado de la calle, además marchaba el resto de la concurrencia, con cartelería alusiva y batiendo palmas.

El cierre del desfile concluyó en el cruce del puente Gorriti y la avenida 19 de abril, punto simbólico de las celebraciones de la Tupac, con un escenario al que accedieron decenas de $d r a g$ queens y personajes carnavalescos para bailar y alentar a la muchedumbre reunida ${ }^{213}$.

${ }^{212}$ Ambos como performance hiperbólicas de la feminidad y la masculinidad.

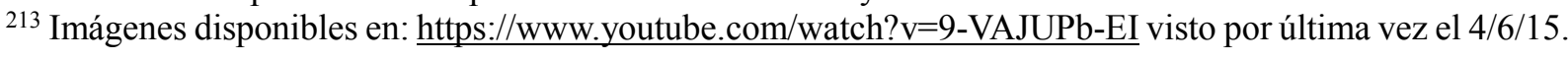


Se llevaron un lugar central en el desfile las tres carrozas alegóricas ${ }^{214}$ que recorrieron el centro de la ciudad, llevando en ellas a reinas de belleza, quienes saludaban efusivamente al público y, cuya marcha fue seguida de cerca y por momentos rodeada por lxs constructores o 'carrocerxs'.

A la vez, afrenta y ejercicio de pertenencia, apelar al uso de carrozas alegóricas remite de manera casi inmediata a los desfiles de la FNE cada año llevados adelante en la emblemática avenida Córdoba de la ciudad. La participación en esta fiesta anual reafirma la inclusión juvenil en los discursos de las tradiciones locales mediante valores estéticos y morales, reafirmando la salud (una que no permite la participación ni de jóvenes trans, ni de chicas embarazadas ${ }^{215}$ ), la belleza (blanca y urbana) y la actitud laboriosa de adolescentes incluidos en el sistema educativo como características apreciables entre los sectores más jóvenes de la población. En la FNE no hay espacio para situaciones diferentes a esta juventud ideal que es considerada la norma y no la excepción (Ficoseco, 2007; Gaona y Ficoseco, 2012). No queda margen ni para otras etnicidades, ni para cuerpos ajenos a las estructuras de la docilidad femenina inscripta sólo en cismujeres $^{216}$, ni para los sectores excluidos de la educación formal (por condiciones de género o de clase).

También incluidas en los anexos.

214 La primera carroza, con la alegoría del Partenón griego; la segunda, que representaba a la naturaleza de las yungas (terreno selvático provincial), con la alegoría de un yaguareté; y una tercera, con dos pilares dorados, un piso de flores y una pared con los colores del arco iris y la identificación de la localidad de Palpalá. Para la segunda marcha, en el año 2014, ya se incorporaron al desfile más de 17 carrozas y a cada uno de los grupos carroceros se les entregó un trofeo en reconocimiento, en un ritual similar a la premiación en el cierre de los desfiles de la FNE.

${ }^{215}$ Casos de este tipo fueron retomados de manera lateral en la tesis acerca de la construcción hegemónica de las mujeres jóvenes en la FNE de Ficoseco (2007).

${ }^{216}$ Este término, con el prefijo en latín que significa 'del lado de acá' o 'de este lado', refiere a la asignación de género impuesta al nacer, a fin de contrastar con mujeres que se identifican como tales (como pueden ser las mujeres trans). Un concepto similar, aunque más problemático, es el que ofrece Platero (2009) al hablar de biomujeres. 
En mayor o menor medida voluntaria, como parodia o como sujetxs inscriptxs en los discursos de lo deseable entre las visibilidades jujeñas, es que estas reinas escenifican y resignifican signos identificables con la operatoria más relevante para el control sobre los cuerpos locales.

Si estas reinas se mostraron dóciles o suaves en sus movimientos, en el saludo soberano aunque sumiso- al que compele el rol que están performando, imprimieron de todas maneras sobre la pasividad femenina, una estética diferente, basada en el valor paródico que permite lo camp.

\subsection{Las imágenes de las reinas. La ilusión mujer}

Este deleite por la solemnidad convierte a algunas de las piezas que hacen parte del desfile en elementos de una potencia sumamente disruptiva. Como ya hemos planteado en otros pasajes de esta tesis, la copia difractaria encuentra en la artificialidad de las réplicas los recursos para volcar sobre el significante, una fuerza que permite trastrocar símbolos caros a los sistemas de valores tanto locales como en un espectro más amplio.

Estas reinas trans en vestidos de gala imponen mediante el amaneramiento de sus saludos señoriales al público una nueva imagen que consigue terminar de desnaturalizar la pieza estética generada en torno de las reinas estudiantiles y su valor como insignias referentes de la mujer fantasmagórica deseada. Se copia de manera crítica, porque quien enuncia su reinado mediante un atril, sus gestos y su postura en la carroza no podría en otras condiciones desfilar de ninguna manera como reina de los estudiantes. Tampoco podrían acompañarla una drag queen y un drag 
king bailando a cada lado. Esta sátira intenta la seriedad de la majestuosidad que se les atribuye en Jujuy a las reinas -de manera, por cierto, para nada irónica.

Es una apuesta permanente en la organización, entramadxs en las intenciones de la pertenencia inclusiva demandante ${ }^{217}$, el retomar ciertos mitos locales y hacerlos circular con métodos propios en un carril paralelo que no puede llegar a asimilarse con los repertorios previos de identificación locales, pero que terminan por perturbarlos y deformarlos, impregnándolos de manera definitiva. Así como en este caso se restituye la figura de la reina jujeña, se puede pensar históricamente en la imagen que hace de Eva Perón, Perlóngher ${ }^{218}$. Ambos pastiches entre realidad y mito hablan de los trayectos afectivos icónicos que suponen el devenir mujer para el colectivo queer, trans y gay.

Lo alegórico, en ninguno de los dos casos, ni en los desfiles de la FNE ni en esta marcha, es la carroza, como suele señalarse. La alegoría está en los cuerpos, con los vestidos, las pompas y el maquillaje, poniendo en cada unx de ellxs las pretensiones de explotación de lo femenino en términos de un canon barroco.

La parodia, entonces, no requiere de una disidencia explícita sobre los símbolos, ni de una transgresión burlesca ${ }^{219}$, sino simplemente, de un procedimiento de imitación por una vía

${ }^{217}$ No hay una voluntad por desentenderse de los símbolos locales, sino que buscan hacer parte de ellos. Así, año a año los colegios secundarios Olga Arédez y Germán Abdala de la organización participan de las fases de elección de reinas estudiantiles locales, como de los desfiles de carrozas.

218 Tanto los textos de Perlóngher (2008), como la obra de Copi (2000) apelan a la exageración y explotación de la imagen de Eva, más como símbolo religioso travestido que como figura política tradicional.

${ }^{219}$ Aquí hacemos alusión a dos de las definiciones más comunes a la hora de hablar de lo paródico como son las de Bajtin (2003), que encuentra en la risa carnavalesca y burlesca una vía de ruptura subversiva con la seriedad del dominio y Kristeva (1981) como transgresión en la reescritura crítica de los símbolos. El humor como actitud de resistencia es una característica pocas veces destacada entre las recurrentes alusiones públicas que se hacen acerca de la Tupac y de Milagro Sala. Sin embargo, a lo largo de estos 
tangencial que termine por modificar la percepción en un nuevo sentido basado en el contexto divergente (Amícola, 2000; Figari, 2009).

La pura discursividad de los cuerpos más estrambóticos de la marcha evidencia la dimensión política de las distintas intensidades de feminidad y masculinidad como circulaciones estéticas. Pero sobre todo, la exuberancia de la feminidad expuesta de modos kitsch, ese máximo de belleza con el mínimo de esfuerzo -el taco aguja, el maquillaje excesivo ${ }^{220}$, las prendas que delinean las curvas-, se ubica como sombra estética cuestionable de la representación de los personajes caricaturescos de la cultura pop gay y de las figuras carnavalescas de orígenes no próximos. De igual manera que esas otras escenas kitsch en la Tupac, como son las puestas en escena de los tipoy o los overoles para las marchas.

Sin embargo, este tipo de escenificaciones, la explotación de toda una serie de códigos identificables en la subcultura LGBT, desde el empoderamiento femenino al que aluden Gatubela o la mujer maravilla, los coros de la canción de Thalía 'A quién le importa', los dotes rítmicos de quienes bailan sobre plataformas y tacos al ritmo de los tambores de la batucada, hacen de la exuberancia actitudinal, gestual y corporal una re-territorialización que pretende subvertir las experiencias corporales femeninas no hegemónicas. En una actitud agente que se distingue ya desde la asimilación de expresiones como queer, 'locas' o 'mariconas' como parte de las auto-identificaciones afirmativas del colectivo, esta exageración de las feminidades

años el recurso de la parodización, como de la ironía de ciertas instancias de lo político local han mostrado la capacidad inquisitiva de la trivialización como recurso de crítica social por parte, tanto de los militantes de base, como de los líderes de la Tupac y de sus lógicas de acción.

${ }^{220}$ Como parte de las actividades de formación que generó el área de Diversidad de género de la Tupac, meses después de la segunda marchase encuentra el taller de maquillaje para drag queens, taller que copó los 200 cupos disponibles en el transcurso de menos de una semana de inscripción. 
estigmatizadas en otros ámbitos. "Es bueno porque es horrible" (Sontag, 2008: 321) ese nivel de artificialidad hiperbólica de la feminidad y de una nueva 'mujer'221 fantasmática ${ }^{222}$.

Quedaría abierta la pregunta acerca de qué resulta más drag y más camp: si los brillos, purpurinas y lentejuelas de los que se recubren cada unx de lxs drags en los desfiles o todas esas obreras en overoles anchos beige y cabezas atadas con remeras y gorras deportivas. Claro que ambas imágenes hacen a la androginia recurrente de las corporalidades que se van aunando en torno de la Tupac.

\subsection{Experiencia y autoconciencia}

Aunque esta marcha y su segunda edición, realizada en noviembre de $2014^{223}$, supongan los eventos más destacados públicamente en lo que respecta a las acciones militantes en torno a las sexualidades por parte de la Tupac Amaru, ambas son tan solo el desprendimiento de un proceso mucho más rico que se gesta prácticamente desde los inicios de la organización. En parte debido al acrecentado número de mujeres lesbianas que se reconoce desde los inicios entre las líneas fundadoras de la Tupac ${ }^{224}$, en parte a partir de la apuesta por asumir la responsabilidad de la

${ }^{221}$ Se encomilla mujer en un doble sentido irónico, tanto por la estética camp que la genera, como por su efectiva inexistencia por fuera de la eterna fantasmagoría que supone su concreción (el llegar a ser debeauvoiriano, el devenir deleuziano).

222 "Es interesante destacar que las mujeres no se presentan, en primera instancia, como productoras de sentido camp, y que son, más bien, el objeto obligado de la representación a través de un espejo distorsionante de la supuesta esencia de lo femenino" (Amícola, 2000: 50)

${ }^{223}$ En la modificación se incorporan al calendario nacional del mes del orgullo LGBT.

${ }^{224}$ Entre quienes podemos destacar a Bety y Anita, dos mujeres de alrededor de 50 años, quienes se reconocen presentes en el movimiento desde sus orígenes. Hoy, ambas militantes también desde el área de Diversidad. 
resolución de situaciones y problemáticas al interior de la comunidad LGBT en la organización (filiales y de vínculos afectivos, legales ${ }^{225}$, de acompañamiento, apoyo emocional y soporte laboral y económico ${ }^{226}$ ).

A partir de la estabilización del colectivo de Diversidad como un área más de las de la organización, la elaboración de una nueva política de reconocimiento se sostuvo en un doble andamiaje: la intención de retomar categorías y métodos que se sustentan en la afinidad colectiva con la causa en favor de una nueva instancia del bien común, como una faz asociativa a partir de la autoconciencia grupal.

Partir del supuesto de que no se trata de una segregación al interior del movimiento como trasgresión segmentada, sino producto del desenvolvimiento agente de las condiciones de

${ }^{225}$ L: Nos juntamos cuando yo estaba con... al juntarme con ella yo tenía otra pareja y ella me llevó a juicio. Y: Mira como es la igualdad acá en la CTA, ella te va a contar.

L: Me llevó a juicio en la organización.

¿Ella trabajaba acá también?

L: Sí, y bueno, yo me separo de ella. Yo ya estaba separada, sino que vivíamos en el mismo lado porque era que nos íbamos a dividir los bienes. Y después llegamos acá a la organización y yo me enamoro de ella [señala a Y]. Y le dejo todo, me voy y salgo. Porque ella me saca así de una, con lo que tenía puesto, pantalón, una remera y un par de zapatillas, nada más. Y el documento, porque yo ya lo había sacado, se lo había dado a ella ya. Y después me hace citar a la abogada. Voy a la abogada con la gente de derechos humanos. Y me dice que yo estaba en falta, porque yo me había ido y ando con otra persona.

¿Y hacía mucho que vivías con ella?

L: Y yo con ella viví desde los 22 años. Y entonces me llevan, me citan dos veces. Y ya en la segunda me fulminaron porque me dijeron que tenía que pasarle el comué alimenticio. Y yo les decía por qué si ella se quedó con todo, me dejó sin nada y encima le tengo que dar la mitad de mi sueldo por cuántos meses. Me dicen 'no, vos le tenés que pasar'.

¿Los mismos abogados de la Tupac hicieron el juicio?

L: Sí. Perdí también ahí. Perdí mi casa, perdí la mitad de mi sueldo por un buen tiempo, hasta que después yo hablé con la Claudia, con la hija de la flaca, cómo podía hacer porque no era justo, si ella me seguía quitando la mitad del sueldo. (...) Encima que me quita la mitad del sueldo, me quitó todo y me deja en la calle. Encima le tengo que seguir pagando. 'Por los años que te ha servido' me dijo la abogada. Sea como sea te ha servido muchos años. (L e Y, Obreras-militantes, entrevista de diciembre de 2010).

226 "Comenzamos por contar experiencias de vida porque por ahí uno lo tiene tan guardado que dice 'no se lo cuento a nadie y que quede ahí, como un mal recuerdo'. Pero los chicos, cuando uno lo cuenta dicen, 'bueno, le puedo contar a alguien, le puedo decir a alguien"' (Obrero-militante, entrevista de octubre de 2013). 
reproductibilidad de la vida por parte de un conjunto de individuos que derivan de manera -no casualmente- colectiva en la Tupac, supone asimilar buena parte de las acciones en concreto como resultado de una elaboración de transformación con raíz feminista.

Así, cuando hablamos de autoconciencia, lo hacemos considerando el proceso de grupalidad para el diálogo sobre el que se cimienta de manera más permanente la labor de los integrantes del área de Diversidad. Las reuniones en grupos de mayor o menor número, con familiares de lxs sujetxs involucradxs, en el interior de la provincia, como en la ciudad, los relatos y entrevistas en el programa radial semanal del colectivo. Todo ello se consigna como parte de una elaboración de reconocimiento de la experiencia compartida.

Entre lo observado en el campo, hacemos uso de la caracterización de la experiencia que propone Bach (2010) en el doble sentido de pasada y presente: como conocimiento reunido en base a acontecimientos previos, una observación consciente y reflexiva sobre lo sucedido, y una conciencia presente activa, como parte de un proceso hacia la autoconciencia, tanto compartida, como diferenciada entre algunxs. El proceso de grupalidad permite llevar de una fase subjetiva individual de la experiencia hacia una que genere una reelaboración mediante un encuentro en la red de significados en común, lo que propicia la acción política a partir de la colectivización.

La validación de la experiencia personal como inscripta en trayectos comunes a otros discursos con los que se encuentran trayectos similares la rearticula haciendo reconocible el peso de la encarnación sexuada y situada.

Las escenas más recurrentes que relatan los integrantes del área de Diversidad refieren a 
situaciones de coming-out ${ }^{227}$ y relatos tormentosos acerca de las trayectorias de lxs sujetxs ${ }^{228}$.

Se vuelve a observar en gran medida el doblez intrínseco a la sexualidad contemporánea: la

confesionalidad y la medicalización (Foucault, 2014). La inmanencia de ambas a la

configuración de las sexualidades disidentes en el contexto jujeño viene a reafirmar a dichas

sexualidades como un modo diferente (perverso) de callar, distinto de las arquitecturas

disciplinarias del decoro y el recato de la heterosexualidad como naturaleza autorizada a

227 "Lo primero que uno sufre es al rechazo de los padres, yo siempre tuve miedo al rechazo ese, porque yo siempre tuve una muy buena relación. Entonces me preocupaba poder contarles que yo era gay, por ahí no ser aceptado. Es uno mismo el que por ahí se pone una barrera porque los padres los aceptan a sus hijos por lo que son. Primero yo tenía mucho miedo de mis amigos. Inclusive yo me cambié de barrio. Tenía miedo que ellos vieran como yo estaba, porque hace bastante que estaba con una chica. Y que ahí estaba con un chico. Y yo estaba con la chica solo para mantener la imagen, para no mostrarle a la sociedad que yo era gay. Después de a poco... (...) Tenía miedo de que me vieran con alguien así que me fui del barrio. (...) A mi papá se lo conté el día que yo desfilaba para la marcha del orgullo. Y fueron a verme y sí, estaban muy contentos. A medida que yo pasaba con una carroza, ellos me saludaban. La gente de donde yo trabajo, si bien acá en Jujuy sabían, en El Carmen donde yo trabajaba, no sabían. Y me costó bastante, porque por ahí tenían otra figura de la cual yo soy responsable. Y no, bueno, me sentí bastante contenido. Al otro día fue toda una revolución, todos saludándome. Y diciendo que contaba con su apoyo." (Obrero-militante, entrevista de octubre de 2013)

228 "Una madre y una hermana nos dicen (...) 'ellos andaban viviendo en la calle en Buenos Aires y les hablamos de este grupo que está, para que le ayude. Yo estoy bien con mi hijo pero me gustaría que lo ayuden, que él también se sienta bien con los demás, que no se tiene que ir de Jujuy'. Ella me contaba que cuando se fue, se fue de varón, se escapó de la casa y cuando llegó, llegó de mujer. Y para transformarse tuvo que prostituirse. Que a ella le dolió que, ósea se sintió mal creyendo que ella había sido mala madre. (...) Hicimos un grupo de diversidad de género en San Pedro, que es una de las localidades donde más chicos hay. Encima allá nos tocó la particularidad de conocer un chico que era gay y que sabía que tenía HIV. Y él murió. Pero por lo menos murió pudiéndole contar a la madre. Ósea, fue triste pero él me decía en los viajes 'por lo menos le pude contar a mi familia y quizás si hubiese habido un grupo así anterior, yo me hubiese cuidado de esto'. Porque él, cuando lo fuimos a ver estaba muy flaquito y me dijo 'mirá, yo creo que tengo sida pero no quiero ir a ver'. Ósea, tenía miedo de ir a hacerse el análisis. Y bueno, ahí empezamos a visitarlo. Estaba bien. Pero un día cayó y murió. Fue bastante doloroso, porque fue un día antes de la marcha del orgullo gay. Él inclusive ya se había hecho una ropa y todo. Pero él a una de las chicas le había contado que se sentía contenido por fin, que alguien lo escuchaba, que no tenía que mentir en esas cosas. Porque él era uno de los chicos que se había ido a vivir a Buenos Aires. La mayoría de la gente que está en San Pedro se termina yendo. Cuando uno ve por ahí los informes periodísticos de prostitución, muchos de los chicos son de Salta, de Jujuy, de Tucumán. Ellos mismos nos cuentan que es increíble la cantidad de chicos que se van para allá. Dicen 'me voy por trabajo' y ya es un mundo tan grande que pueden mostrar lo que son, pero a la vez tienen que hacer cosas que por ahí, como no hay un trabajo, un lugar, quizás la sociedad misma sabe lo que uno es. Sienten como que es la calle nomás" (Obrero-Militante, entrevista de octubre de 2013). 
silenciarse en la creación moderna de lo privado.

A modo de palabras de cierre parcial, consideramos que la óptica progresiva en la que se ramifica la organización se alza nuevamente mediante una identificación estratégica. Sin embargo, la lucha más radical contra el régimen de normalización que continúa operando parece darse en el reconocimiento de la transversalidad y multiplicidad de opresiones, más que en la representación política de la identificación sexual. Las vías más potentes de transformación y emancipación parecen darse en dos caminos de lo practicado: en las alianzas transversales de resistencia estratégica a la norma (el lazo comunitario, la discusión de algunos indecibles, la rearticulación de lo experimentado) y en la reapropiación corporal de figuras hegemónicas por parte de cuerpos múltiples y bizarrxs que conmocionan la estabilidad de lo visible. 


\section{CONCLUSIONES}

\section{I.}

Esta tesis ha buscado considerar la experiencia territorial construyéndola analíticamente como una escena en el presente. La tarea, compleja por lo que supone un análisis cultural de un proceso político en curso, ha procurado conjugar un análisis crítico a partir de imágenes de aquello que hemos reconocido como parte de un movimiento social, en vinculación con diferentes articulaciones hegemónicas rastreables en el contexto local jujeño. Así, las fibras que han tejido empíricamente la investigación y que han movilizado las reflexiones de la tesis se establecieron sobre la base de lo que construimos como el sujeto social Tupac Amaru y su relación con la capital provincial, San Salvador de Jujuy. La trama que observamos se ramificó en una exploración sobre un vasto repertorio discursivo con la intención de reconstruir críticamente el modo en que se entablan voluntades de forma y reparto de sentidos asignados. De esta diseminación empírica se ha procurado conjugar un corpus concreto que se escalona como imágenes y discursos supeditados a la pregunta inicial sobre la conflictividad de la diferencia en el contexto urbano y su desenvolvimiento a partir de los movimientos multitudinarios.

Esta pregunta inicial se despliega y ramifica a lo largo de otros cuestionamientos que impregnan cada uno de los apartados de la tesis, como son la pregunta por las vías que han 
adoptado las desigualdades materiales históricas al interior de la sociedad capitalina jujeña -al menos en el último cuarto de siglo XX y principios de este-; cómo opera y se organiza simbólicamente la diferencia a nivel local; el modo en el que se tejen las relaciones de poder y las articulaciones hegemónicas territorial y experiencialmente; los hilos que van urdiendo y actualizando las demandas históricas locales en un sujeto colectivo; los indicios del deseo colectivo que podemos observar materializados a través de él; el cruce que allí se presta a observar entre producción de conocimiento a partir de la experiencia, agencia y empoderamiento colectivo; y los aspectos dialécticos permanentes percibidos en la búsqueda de lo comunitario.

Todas estas instancias fueron puestas en juego y observadas desde el carácter activo y movilizante de lo simbólico, su inmanente condición de opacidad y polisemia, de transformación y reactivación. Es así que la conformación de un sujeto de análisis para esta investigación ha requerido asumir las complejidades de la amalgama de sentidos que convergen en él. Así también, se ha dispuesto una metodología etnográfica que apela a la heterodoxia en la recolección empírica a fin de abarcar de la mejor manera posible y del modo más adecuado el fenómeno observado. Como herramientas hemos dispuesto de las entrevistas y los diálogos informales, de la observación participante, la recolección mediática digital, gráfica y audiovisual disponible, la incorporación de materiales institucionales, y los discursos e imágenes volcados en redes sociales masivas.

A partir de ellos, la cartografía deseante como método de inscripción en el flujo relacional nos ha permitido observar al fenómeno a través de un mapa de efectos de superficie. Todas las líneas abiertas fueron dispuestas de cara a un proceso complejo y rizomático, lo que ha requerido de un abordaje crítico cultural de carácter fragmentario y rapsódico; es decir, un acercamiento 
parcial y modulado por distintos discursos y voces.

Para un seguimiento que pueda dar cuenta de las derivas y corrimientos perceptuales hemos establecido una periodización que, como estrategia metodológica, procuró definir un modo de lectura del fenómeno analizado que reconozca las variabilidades de su curso histórico. El eje problemático fue formulado a partir del cruce 'crecimiento multitudinario-conflictividad visible'. Consideramos que esta herramienta generada nos permitió y nos va a permitir sostener las consideraciones analíticas como línea de continuidad para la investigación a partir de este cruce.

Este fue el esquema de armado del problema, la escena y el sujeto de análisis, así como la metodología para el abordaje. Además, hemos establecido un recorrido de antecedentes para sentar las bases de las líneas más destacadas en los estudios que refieren a la movilización colectiva de sectores populares en Argentina en el último período histórico, con foco puesto en los estudios de género y en investigaciones acerca de la organización analizada. El repaso por los antecedentes nacionales y locales en torno de la beligerancia y la acción territorial permitieron armar un mapa contextual para el análisis. Sin embargo, consideramos que el peso de la Tupac Amaru a nivel político y simbólico en el plano actual local la ubicarán como bisagra histórica de los movimientos sociales y de las formas de empoderamiento por parte de los sectores populares. Asimismo, observamos que el cruce entre la coyuntura sobre la que se constituye el análisis y el tipo de preguntas establecidas a partir de la elaboración conceptual en la tesis se asientan en diálogo teórico con dichos antecedentes y permite bifurcar parte de los resultados propiciando líneas fructíferas que serán continuadas como parte de la propia investigación futura. 
Asimismo, con los antecedentes teóricos locales con los que se establecen cruces permanentes y de los que la investigación se beneficia para poder pensar cabalmente la ciudad y sus procesos simbólicos, se procura un ensamblaje teórico coyuntural en el que el contexto promueve los términos de comprensión y elaboración para la crítica. Así, desde el análisis que establece García Vargas (2010b) de los espacios de ciudad de San Salvador de Jujuy construyendo de manera cabal una cartografía teórica basada en la materialidad del espacio físico, el espacio social y el espacio mediático, propusimos en esta investigación intentar incorporar a los espacios virtuales como parte de dichas edificaciones simbólicas, dado el modo contemporáneo de la experiencia de la ciudad. Asimismo, incorporamos el juego dialéctico permanente entre corporalidad y espacio social, atendiendo a las operaciones y condicionamientos que constituyen a la alteridad como parte de los mapas urbanos hegemónicos. Todas estas armas teóricas se sustentan además en las premisas del espacio como eminentemente político, generizado, producido en la experiencia y las relaciones, heterogéneo y jerárquico (Massey, 2004), y a la ciudad como terreno de disputas, y propiciadora de desigualdades materiales y simbólicas que operan performativamente sobre lxs sujetxs. La potencia política de los espacios y la ciudad fue reconocida en torno de las nociones de geografías de poder (Ibíd.), resistencia y derecho a la ciudad (Harvey, 2014) a partir de los movimientos sociales como productores contrahegemónicos o alternativos de sus sentidos dominantes.

Es desde estas dimensiones teóricas que hemos establecido un recorrido por las configuraciones urbanas de los últimos años en la capital provincial. A partir de un trayecto por la situación de ingobernabilidad provincial durante toda la década de los ‘90 (Lagos y Gutiérrez, 2009), un rapaz Estado nacional neoliberal, la escalada de desocupación, exclusión y 
marginalidad, la desarticulación de las escalas productivas provinciales, y la elevación y el constante conflicto social, consideramos que se configuran tres instancias de experiencia ciudadana local que atravesaron toda la investigación: un sector de la población que se desvincula de la acción participativa política, un sector tendiente al conflicto público en razón de demandas de clase frente al Estado, y un gobierno caudillista justicialista que responde a los rumbos federales sin un fuerte peso de reconocimiento y legitimidad local. Si algo queda sentado a partir del recorrido por la historia reciente jujeña es que las fibras que construyen los caminos de la política no se han dado por la vía de los partidos políticos tradicionales, sino por la lucha de sus sectores populares y sindicales.

Establecemos una línea común que observamos entre conflicto social y estructuración de la ciudad. Las luchas se dieron en el fragor de medidas que definieron rumbos excluyentes y de fragmentación social. Esta fragmentación, propiciada por el cruce mercantil y estatal local, se ha materializado también en fractura urbana. Estas observaciones quedan plasmadas de manera más plausible entre una retícula (espacial) generada para operar de manera excluyente y expulsiva -regida por las lógicas gestionarias, administrativas, comerciales y turísticas- y lugares predestinados a desplegarse en las desventajas y asimetrías urbanas -con el caso paradigmático del barrio Alto Comedero.

Todos los condimentos hasta aquí mencionados, sumados a las condiciones paupérrimas para la vida de miles y el marcado vuelco hacia la disputa social sentaron las bases para el surgimiento y desarrollo de una organización como la Tupac Amaru. Cuando hablamos de sentar las bases, además de este período prolongado de conflicto y marginalización social, hablamos también de un tipo de Estado como condición. Las dimensiones y la magnitud que alcanzaron a lo largo de 
sus 15 años de conformación formal no son concebibles por fuera de un tipo de Estado y de gobierno. Así, la negociación y alineación a la par de un modelo de gobierno a nivel nacional y las modulaciones estratégicas en la disputa con el poder político provincial, le permitieron consolidarse como vía hegemónica alternativa, tanto en lo que refiere al desarrollo material a partir de los recursos del Estado, como a la disposición masiva de militantes políticxs reunidxs en causas comunes.

En una de las primeras afirmaciones a partir de lo abordado sostenemos que la historicidad disruptiva de la movilización colectiva y el tenor periódico que adquieren esas relaciones de fuerza, y las modificaciones que se pueden configurar entre un modelo de Estado y otro, constituyen a la Tupac Amaru y a distintos movimientos sociales locales de ese tipo como actores que lo confrontan en razón de redefinirlo de manera integracionista o inclusiva. Lo revolucionario en estas experiencias colectivas es lograr la interrupción en el curso histórico de un tipo de Estado en favor de su reconfiguración hacia la mejora en las condiciones de los sectores subalternos.

Ante posiciones teóricas que consideran fuertemente la imposibilidad acontecimental de un movimiento social en torno del Estado, aquí nos preguntamos qué acontecía efectivamente cuando, haciendo y asumiendo plena utilización de sus recursos productivos y la necesidad del subsidio como sustento, se generaban de hecho disrupciones que podrían modificar radicalmente las experiencias de un sector de la ciudadanía en su conjunto.

La Tupac Amaru reúne en la actualidad decenas de miles de afiliadxs y militantes, miles de obrerxs y casi dos mil delegadxs y sub-delegadxs de copas de leche, convirtiéndose así en la organización social más grande del país. En la provincia tiene presencia en las localidades de 
La Quiaca, Humahuaca, Volcán, San Pedro, Calilegua, Libertador Gral. San Martín, Chalicán, Lote Parapetí, Perico, El Carmen, Monterrico, y Palpalá. Las decisiones generales se coordinan en asambleas que funcionan de manera regular una vez por semana. Además de los líderes de la organización, participan de ellas lxs delegadxs y sub-delegadxs de copas de leche, lxs presidentxs de cooperativas y lxs encargadxs de áreas.

Su líder, Milagro Sala, es también la líder de la Red de Organizaciones Sociales en la provincia de Jujuy, una red que nuclea a 27 organizaciones a nivel local. La capacidad adquisitiva de la Tupac Amaru en lo que respecta a la vehiculización de distintos tipos de programas productivos, redistributivos y de asistencia a nivel nacional le permite erigirse como intermediadora de los recursos de otras organizaciones a nivel local. En este sentido, las demás organizaciones se establecen como satélites de las luchas -y de los beneficios obtenidos-desde la Tupac.

Todo el período de investigación se llevó adelante durante una etapa recompositiva en la vida de lxs militantes y obrerxs, y eso se pudo apreciar no solo a partir del relato experiencial con marcados quiebres respecto de sus trayectorias previas, sino por el notorio desenvolvimiento cotidiano en condiciones de mejora en sus vidas. Vivienda, trabajo, educación y salud son significantes vacíos contemporáneos, y desde nuestros objetivos y nuestras interrogaciones buscamos también dar cuenta de ellos como hilos minúsculos que se tejen en una compleja urdimbre de tal nivel de trascendencia hasta en lo más ínfimo de la vida de las personas que solo en el enfático contraste entre lo que fueron y son las experiencias de lxs sujetxs es apreciable. Se han reconocido situaciones de autonomización, empoderamiento, concienciación, autoreconocimiento valorativo y dignificación de la experiencia humana. 
En este panorama de colectivización, organización y articulación con el Estado pudimos apreciar además la promoción de formas de discursos modernistas, desarrollistas y progresistas, entramados de manera dialéctica con rasgos comunitarios y emancipatorios. Todas estas características sin escapar de ciertos tintes locales de reivindicación de las clases populares y de la cultura villera, de reconocimiento y restitución afirmativa de los caminos sinuosos que lxs llevaron al punto de encuentro en una nueva forma de identificación colectiva como es la Tupac.

La magnitud contextual que supone como fenómeno social lo convierte en un proceso que requiere del detalle analítico para poder distinguir entre aquellos elementos que responden a repertorios nacionales y regionales latinoamericanos de acción y lucha en favor de mejores condiciones de vida, y aquellos que hacen a características particulares en tanto la cimentación de la experiencia en los marcos jujeños posee condimentos territoriales, identitarios e históricoculturales específicos.

Además de las ya mencionadas consignas por derechos -vivienda, trabajo, educación y salud-, fueron saliendo a superficie de manera temprana pero con más peso año a año las luchas por la Memoria, la Verdad y la Justicia, y se fueron trayendo a superficie nuevos marcos de reconocimiento en cruce con la condición de clase. Así, como tupaquerxs se nombraron indígenas, mujeres, gays, lesbianas y trans, ancianxs y bolivianxs, para, a partir de allí, disputar nuevos terrenos del reconocimiento social y la humanización de la vida de cada unx de ellxs.

El hecho de hacer de dispositivo por el que drenaron las más vastas formas de demandas de clase históricas a nivel local, le permitió a la organización la acumulación de un capital simbólico que se fue evidenciando de manera más pronunciada a lo largo de los años. Sin dudas 
que el análisis en la nueva encrucijada traducida en configuración política partidaria, primariamente abordada en esta tesis, tiene componentes que requieren del paso del tiempo para continuar observando la posibilidad de cruce directo entre movimientismo, apelación al Estado e institucionalización partidaria.

\section{II.}

Si podemos armar una constelación de imágenes conceptuales a partir de lo dispuesto en la tesis, en movimientos permanentes entre una y otra noción a lo largo de los capítulos, probablemente podamos sintetizarla en las siguientes expresiones: Multitudes articuladas; Trabajo, comunidad y protección; Violencia y precariedad; Liderazgos generizados; Voz y visibilización indígena; Corporalidades sexuadas; y Deseo, acceso, consumo y posesión.

El concepto inicial formulado acerca de las multitudes articuladas puede definirse a grandes rasgos como la congruencia de fuerzas sociales, pluralidad de demandas, y un horizonte constituido por el deseo en el encuentro situado de sujetxs de trayectorias disímiles. Esta noción, aquí sintetizada, opera a lo largo de la tesis para intentar aunar analíticamente al sujeto colectivo mediante la evidencia de su proceder.

La vía de análisis que se sostuvo en la tesis acerca del trabajo y la producción comunitaria no tiene que ver exclusivamente con la gestión productiva comúnmente reconocida en torno de la Tupac. Sino sobre todo con aquellas cadenas de sentido que construyen a lxs tupaquerxs discordantemente entre las imágenes de "esclavxs", "vagxs” y/o "planerxs". 
Hemos observado a lo largo de las obras de construcción y fabriles una honda crudeza del trabajo obrero, que vuelve ciertamente imposible transmitir todo lo que se ve entre los cuerpos de lxs obrerxs, tal nivel de sacrificio y extenuación. Por otro lado, en sus relatos lo que hacen se experimenta mediante al menos dos acepciones comunes respecto de lo que significa el empleo del cuerpo para el trabajo articulado en palabras: aquellxs que asimilan la posibilidad del trabajo como una experiencia que 'soportan' por la obtención de dinero y por el 'miedo' a la pérdida; y entre aquellxs que llegan a elaborarlo con un fin más allá del personal, quienes someten a una reflexión social, la tarea individual. Es decir, que aquello que se hace tiene un fin más allá del interés propio y más próximo. Estas vertientes expresivas se dan de manera confluyente y contradictoria inclusive en relatos por parte de la misma persona.

A lo largo de la tesis, la presencia repetida de la noción de lo comunitario en la obra y en el uso y acceso colectivo se ve atravesada con los anclajes subjetivos en los que se estructura la convivencia. Hay una genealogía de fondo en la noción de lo comunitario, genealogía no necesariamente procesada en el desenvolvimiento de la vida, pero que reflota como pulsión productora en un momento de descomposición, y como noción conservadora ante lo obtenido.

Se reconocieron en este panorama las tensiones del trato en términos de subordinación, y las oscilaciones entre el individualismo y los horizontes colectivos. Así, el engranaje subjetivo obrero se articula en un cruce entre lo agobiante de la tarea, el temor frente al horizonte subjetivo siempre presente de las experiencias de privación y carencias, la vitalidad de las nuevas experiencias de acceso a la posesión y al consumo, y la auto-identificación como parte de un proyecto que encarna en la noción de la moral del trabajo las bases para el bien común. 
Hemos reconocido una apuesta por una restitución de lo colectivo en términos alternativos, pero ello significa y ha significado un precio alto por costear. Los logros materiales de lo popular no descansan sobre lo obtenido, sino que históricamente se han visto y se ven fustigados por los sectores dominantes. Se dirimen de frente con sectores encolerizados que sostienen en pugna las disputas por las balanzas distributivas. Más allá de lo material y lo económico, la reconstrucción de algún tipo de lazo social requiere de márgenes de protección recia y liderazgos fuertes.

La asimetría en el reparto de discursos visibles, y la situación de que buena parte de ellos operen en la lógica de la difamación, el rumor y el estigma, se ejerce como coerción permanente que los constriñe a proteger impetuosa e implacablemente la calle, el barrio, el colectivo reunido, lo que se discute en asamblea, etc. Esta protección, sin embargo, apela a recursos dentro del derrotero de métodos y estrategias que pueden reconocerse en términos pleiteantes y agresivos, sin terminar de enmendar por esa vía las bases para un nuevo tipo de lazo social.

La crítica al proyecto político de la Tupac Amaru opera casi exclusivamente por los carriles del campo discursivo difamatorio respecto de las formas de ejercicio de la violencia que evidencian, y que parece construir Milagro Sala en la presentación de sí misma. Y ante la violencia se disipa cualquier argumentación respecto del proceder político y se traslada el foco comprensivo a las únicas aparentes vías de incorporación: la adhesión o el rechazo. Parece por momentos inaudible la voz política. Sin embargo, se construye de manera indubitable un liderazgo político. Y ese liderazgo se ejerce mediante un descentramiento de los roles de género esperables entre las mujeres políticas visibles y las figuras de la femineidad hegemónicas. Queda claro que más allá de la ratificación popular interna que refiere a su rol de líder en la 
organización, en cualquier elaboración corporal disruptiva, el agente opera en torno de las precariedades del género. Entre la auto-afirmación y los movimientos regresivos que operan para intentar reubicarla y señalarla de forma estigmatizante, pretendimos distinguir el modo en el que la desafiliación de ciertas características normativas sobre sí misma permite imaginar formas de enunciación que arremeten contra las lógicas simbólicas más comunes acerca de la construcción de figuras de poder o en roles de liderazgo. Tal como se ha desarrollado en el apartado Tupaqueras (4.5.), existe una indudable veta común entre su liderazgo y agenciamiento, y las instancias que convocan a las mujeres en la organización.

Estos elementos rastreados de manera indiciaria en la experiencia colectiva, se encuentran en otros momentos expuestos de manera acontecimental cuando ratifican su existencia a modo de demanda. Los dos capítulos finales de la tesis se abocan a ello.

Por un lado, la visibilización y la voz indígenas se analizan asumiendo que, en la necesidad de habitar la vida, los instrumentos distintivos a los que se recurre para 'decirse' se cristalizan generalmente en categorías que segmentan cuotas de reconocimiento en el orden contemporáneo de políticas de identidad.

Las coordenadas de presentación en términos de clase, etnia, nacionalidad, género y sexualidad, entre otras, se materializan transversalizando la experiencia humana, y haciendo de la posibilidad de su señalamiento, condición que genera consecuencias desiguales para la reproductibilidad de la vida. Hablar de la distancia entre representación y experiencia es hablar tanto de los límites que supone la traductibilidad audible en términos identitarios, como de las condiciones para la materialización corporal, vector de dichas demandas. Porque las marcas 
étnicas, racializadas, atraviesan y van más allá en las experiencias cotidianas que lo que supone esta escenificación de lo indígena. Efectivamente, las marcas indígenas condicionan relacionalmente sus experiencias; pero la licencia representacional de la alteridad sólo les permite presentarse a partir del discurso que contingentemente lxs contiene. Las formas estereotípicas étnicas con las que se presentan son funcionales al sistema que las permite. Sin embargo, reconocerlxs solo mediante esos símbolos estereotípicos arma un panorama de lo representable que parece caer en ciertas dificultades.

Lxs militantes de la Tupac Amaru son en su amplia mayoría urbanxs. Pero su discurso acerca de lo indígena indefectiblemente fijado en torno a lo rural ejerce una clausura que excluye su propia existencia en el presente en el ámbito urbano donde experimentan sus vidas. Sus demandas los performan, en tanto ellos se construyen a sí mismos como indígenas sólo en presencia del territorio rural; clausurando así toda posibilidad de pertenencia al presente urbano y de necesidades y demandas que afloran en ese desenvolvimiento. El esbozo de la demanda parece obviar la existencia más próxima, coetánea y co-territorial de muchxs sujetxs.

Si bien existe un marco para la figura visible (en el Estado y en la Tupac), no existiría en el plano ontológico un margen en el cual habitar una ciudadanía más cabal que comprenda lo indígena. No se habilita la posibilidad de existencia por fuera de los discursos hegemónicos mencionados. A pesar de esto, apreciamos que lo que se disputa es la manera de resistir de forma multitudinaria, reapropiándose de los métodos epocales de enunciación.

Por otro lado, en el análisis acerca de la apropiación de la consigna del orgullo y la puesta en escena de cuerpos sexuados en la ciudad para reivindicarse, establecemos un tenor de otro tipo 
por lo que supone una afrenta contra la elaboración hegemónica del género y de las sexualidades en la ciudad. El encuentro del conjunto de individuos que derivan en la Tupac no es casual ni fortuito, sino que se atribuye a un proceso de exclusión local marcado y expresado en la discriminación y el estigma. El área de Diversidad y la marcha del orgullo deben verse a las claras como parte del desenvolvimiento agente empoderado a partir de las modificaciones en condiciones de reproductibilidad de la vida por parte de un grupo que asimila la crudeza de la experiencia subjetiva previa.

Con las complejidades de un panorama heteropatriarcal local tan marcado, la política de reconocimiento al interior del movimiento se define en el armazón táctico de vincular una nueva instancia de afinidad colectiva que se puede ligar al bien común último (reconocimiento de nuevos derechos y de respeto por la diferencia) con una faz asociativa grupal a partir de la autoconciencia.

Hemos distinguido en distintos momentos de la tesis imágenes que flotan con carácter relevante en la constitución de esos ideales varón-mujer locales. Frente a estas figuras hegemónicas, la marcha del orgullo se convierte en una arena de exhibición afirmativa de las intersecciones de la diferencia que no necesariamente coinciden con las categorizaciones más fácilmente aprehensibles o aceptables por parte del orden de género y sexualidades dominante local, o inclusive con la fórmula hegemónica de las sexualidades disidentes. Que sectores empobrecidos, de origen indígena, del interior del país o inmigrantes, de corporalidades de valor estéticamente degradado en el sistema mercantil se manifiesten en la ciudad y mediante la tecnología de visibilidad del orgullo es una afrenta contra la configuración urbana hegemónica y contra las imágenes más recurrentes del propio colectivo LGBT. 
Lo butch, lo femme, lo drag, las reinas son imágenes que explotan de manera barroca en este desfile pero que habitan y conviven en corporalidades diversas en el marco cotidiano de la experiencia colectiva. Se carga sobre los cuerpos un nivel paródico sin siquiera una disidencia explícita sobre los símbolos, sino sencillamente mediante la apelación a la inclusión y el reconocimiento a partir de un procedimiento que espectaculariza el gesto político bifurcando los sentidos de las imágenes a las que apelan.

En su disputa por discutir el régimen reconocemos dos vías que parecen destacarse dado el contexto y los modos procedimentales observados: aquellas alianzas transversales de resistencia estratégica a la norma (lazos y vínculos, puesta en palabra de problemáticas apremiantes, la articulación de experiencia colectiva) y en la reapropiación corporal de figuras hegemónicas por parte de cuerpos múltiples y bizarrxs que conmocionan la estabilidad de lo visible.

Un último elemento consignado como parte de la constelación conceptual armada se sostiene sobre el deseo como axioma radical reformulante (Guattari y Rolnik, 2006), al que solo podemos aspirar acceder de manera indiciaria a partir de lo que son las líneas productivas trazadas entre el acceso, el consumo y la posesión.

Hay una distancia perceptual entre 'tener' la casa, un par de zapatillas, los muebles de una casa, una moto, un auto, condiciones de ese tipo, y otras materialidades a las que se acceden, como son el parque temático y acuático, el templo como exhibición vistosa, los festejos de reyes magos y día del niño; o en menor medida las piletas y los quinchos por distintos puntos de la ciudad, y la oferta de espectáculos y consumos culturales gratuitos. Probablemente entre la moral de reparación de la primera enumeración y la reconstrucción paradigmática inclusiva de 
la segunda se encuentren los rasgos más evidentes de la magnitud política de la Tupac Amaru.

Se asume que existe una constelación de imágenes que aluden a los bienes, al espectáculo y a un tipo de esparcimiento como símbolos de algún modo de pertenencia y como ejecución del consumo. Ellos son incorporados en la agenda de producción y construcción de la ciudad. Pero se modifican las condiciones para el acceso a dichos elementos de valor. Hemos mencionado en distintos momentos de la tesis que la Tupac Amaru no busca adherir a una moral utópica por fuera de la senda del capital y el Estado, sino que interpreta parte del deseo colectivo y los concreta mediante una modificación en la economía de los símbolos en una lógica redistributiva.

La experimentación fáustica presente en muchas instancias movilizadoras de la organización promueve otras racionalidades de lo económico y de la moral de las necesidades. Si como colectivo surgieron de la necesidad urgente, encuentran en estos 'gastos' inversiones que adscriben al gasto productivo en las lógicas de un regocijo por otra vía, un potlatch alternativo local.

\section{III.}

Esta investigación se propuso ser una instancia de visibilización crítica de aquello que acontece como un fenómeno masivo, multitudinario y de magnitudes insoslayables en San Salvador de Jujuy. Decimos visibilización y crítica en un juego de palabras por el evidente carácter visible que tiene en el contexto jujeño la Tupac Amaru. Empero, la puesta en curso de una mirada crítica ha sido difícilmente hallable en los últimos años en el plano local. El sentido común, como 
aleación peligrosa de discursos, ha primado en la configuración de las imágenes recurrentes respecto de lo que significa la vida de miles de personas y, en definitiva, de los designios políticos posteriores de la provincia.

La problematización expuesta procuró formular posiciones claras que evidencian la dimensión política que hace parte de la teorización de los escenarios locales actuales. La teoría se concibe de manera consciente a fin de orientar la práctica en vistas a una transformación. Es un intento por participar de debates en los que nos involucramos, reconociendo en la traducción cultural formas posibles de visibilizar condiciones que actúan de manera desfavorable para un vasto sector social de nuestra región.

Hemos mencionado repetidamente el valor fundamental que le damos a la teoría en un sentido contextual y contingente, en tanto que ella se esboza esencialmente por condiciones que se lo requieren y permiten, como por la función y el rol que ocupa, respondiendo y permeando desde la crítica a un marco contingente.

Lo político cuestiona y debe ser cuestionado para avizorar en sus fórmulas las potencialidades regenerativas. La reflexión y la crítica no pueden ser algo previo a la acción política, sino que ésta requiere de constante ejercicio crítico como razón para su propio avance.

Las líneas planteadas en la tesis se estiman como temáticas de continuidad en la investigación que de seguro encontrará, en un nuevo panorama político, modificaciones estructurales para el tipo de preguntas que nos hacemos. Las operaciones de la diferencia, las articulaciones hegemónicas, la activación de mecanismos de sostenimiento de lo conseguido, las rúbricas comunitarias encontradas en lo colectivo, entre otras preguntas que atañen a la identificación, la 
experiencia y la vida en la ciudad requerirán de la agudeza crítica para contribuir a las disputas desde el plano interpretativo de lo social. Por lo pronto, se encauzan como derivas de esta investigación las formas que adquiera un nuevo mapa de distribución de sentidos en un contexto político diferente, de qué manera se librarán las contiendas del reconocimiento y los derechos desde la diferencia a partir de lo ya sentado, de qué modo de desplegará la noción de la dignidad en las contiendas de resistencia y reafirmación ante nuevos contextos, qué demandas y actores se visibilicen ante un aparente reordenamiento de los sectores populares; además del seguimiento de los incipientes modos de establecimiento de las disputas LGBT en el plano jujeño, no solo en el marco de la Tupac Amaru, y el cruce de estas aristas afirmativas con la experiencia indígena y popular en la ciudad.

El período de análisis de esta tesis se ha dado en un marco de evidente recomposición para la vida de muchxs de lxs militantes. Y aun en el vigorizador ambiente de un sector social movilizado y concienciado, no dejó de percibirse el temor a los embates corrosivos de lo que allí se estaba gestando. La manifestación de las demandas los ingresó de alguna manera a la existencia e interpeló de manera problemática a la ‘comunidad' (Butler, 2009).

Asumimos que los caminos hacia la transformación, las fugas emancipatorias y la humanización de la vida no pueden darse sino mediante la visibilización del conflicto, y que en el consenso y la conformidad no se experimenta más que el silenciamiento y entumecimiento de lxs vulneradxs y oprimidxs. Así también, que si algo deja abierto este proceso -y que ya ha sido observado en otras experiencias comunitarias de menor escala a nivel local-son las hebras del vigor político de los sectores populares que resisten y disputan la ciudad. 
El análisis logrado acerca del movimiento social se llevó a cabo enteramente en un panorama en el cual un tipo de Estado -y de gobiernos- sentó parte de las condiciones necesarias para este tipo de desarrollo. Asimismo, se llevó adelante en un panorama de crecientes manifestaciones de rechazo y estupor públicos por un proyecto que reasignaba los destinos populares.

Consideramos que concluimos de manera acabada con un período investigativo que fue movilizador y estimulante, y que los vaivenes periódicos políticos nos dejarán a las claras que una cualidad de las resistencias populares es su carácter perdurable. 


\section{REFERENCIAS BIBLIOGRÁFICAS}

ABU-LUGHOD, L. (2006). "La interpretación de la(s) cultura(s) después de la televisión” en Etnografías contemporáneas. UNSAM, 1 .

ACHUGAR, H. (2000). "Sobre el 'balbuceo teórico' latinoamericano" en Rico, A. y Acosta, Y. (Comp.), Filosofía Latinoamericana, globalización y democracia. Uruguay, Facultad de Humanidades y Ciencias de la Educación-Nordan Comunidad.

ADORNO, T. W. (1962). "El ensayo como forma” en Notas de literatura. España, Ariel.

ALABARCES, P., GARRIGA ZUCAL, J. y MOREIRA, M. V. (2008). “El ‘aguante’ y las hinchadas argentinas: una relación violenta" en Horizontes antropológicos, 14, 30.

ALBÓ, X. (2008). Movimientos y poder indígena en Bolivia, Ecuador y Perú. Bolivia, CIPCA. ALCOFF, L. (1999). “Merlau-Ponty y la teoría feminista de la experiencia” en Mora, 5.

ALZINA, P. (2012). Tupaqueros, la construcción de las identidades en los movimientos sociales. Buenos Aires, Ediciones del CCC.

AMÍCOLA, J. (2000). Camp y posvanguardia. Manifestaciones culturales de un siglo fenecido. Buenos Aires, Paidós.

ANDÚJAR, A. (2005). Mujeres piqueteras: la repolitización de los espacios de resistencia en la Argentina (1996-2001). Informe final del concurso: Poder y nuevas experiencias democráticas en América Latina y el Caribe. Programa Regional de Becas CLACSO.

ANZALDÚA, G. (1999 [1988]). Borderland/La Frontera: the new mestiza. Estados Unidos, 
Aunt Lute Books.

AUYERO, J. (2004). Vidas beligerantes. Dos mujeres argentinas, dos protestas. Bernal, Ed. de la Universidad Nacional de Quilmes.

AUYERO, J. (2001). La política de los pobres. Las prácticas clientelistas del peronismo. Buenos Aires, Cuadernos Argentinos Mananatial.

AUYERO, J. y CAFASSI, E. (2002). La protesta. Retratos de la beligerancia popular en la Argentina democrática. Buenos Aires, Libros del Rojas.

BACH, A. M. (2010). Las voces de la experiencia: el viraje de la filosofía feminista. Buenos Aires, Biblos.

BAJTIN, M. (2003). La cultura popular en la Edad Media y el Renacimiento. El contexto de Francais Rebelais. $3^{\circ}$ Reimpr. España, Alianza Editorial.

BALlENT, A. (2009). Las huellas de la política: vivienda, ciudad, peronismo en Buenos Aires, 1943-1955. Bernal, EDUNQ.

BARRIOS, R. y FERNÁNDEZ, N. (2008). “(Con)vivir con el peronismo. Vivienda y ciudad durante el primer peronismo" en Actas del $1^{\circ}$ Congreso de Estudios sobre el Peronismo: La Primera Década. Mar del Plata, Red de Estudios sobre el Peronismo.

BARTHES, R. (2014). Fragmentos de un discurso amoroso. $1^{\circ}$ Ed. (especial). Buenos Aires, Siglo XXI Editores.

BARTHES, R. (2005). Cómo vivir juntos: simulaciones novelescas de algunos espacios cotidianos. Buenos Aires, Siglo XXI.

BARTOLOMÉ, M. (2010). "Intreculturalidad y territorialidades confrontadas en América Latina” en Runa, 31, 1.

BATAILLE, G. (1987). La parte maldita. España, Icaria. 
BATTEZZATI, S. (2014). "La Tupac Amaru: movilización, organización interna y alianza con el kirchnerismo (2003-2011)" en Población y sociedad, 21, 1.

BATTEZZATI, S. (2012). "La Tupac Amaru: intermediación de intereses de los sectores populares informales en la provincia de Jujuy” en Desarrollo económico, 52, 205.

BELL HOOKS (1981). Aint I a woman. Black women and feminism. Estados Unidos, South end Press.

BELLI, E. y SLAVUTSKY, R. (1994). "Flores, reinas y carrozas. Reflexiones sobre la identidad en San Salvador de Jujuy" en Karasik, G. (comp.), Cultura e identidad en el noroeste argentino. Buenos Aires, Centro Editor de América Latina.

BELLUCCI, M. (2010). Orgullo. Carlos Jaúregui, una biografia política. Buenos Aires, Emecé.

BENJAMIN, W. (2005). Libro de los pasajes. España, Akal.

BENJAMIN, W. (2003). La obra de arte en la época de su reproductibilidad técnica. México, Itaca.

BERGER, J. (2000). Modos de ver. $2^{\circ}$ Ed. España, Editorial Gustavo Gili S. A.

BERGESIO, L. y GOLOVANEVSKY, L. (2010). "Crecimiento urbano y fragmentación social. Breve historia del surgimiento y expansión del barrio Alto Comedero" en García Vargas, A. (comp.), Ciudad. San Salvador de Jujuy como texto. San Salvador de Jujuy, EdiUnju.

BERGESIO, L., GOLOVANEVSKY, L. y MARCOLERI, M. E. (2009A). Construcción social de la ciudad. San Salvador de Jujuy desde el barrio Alto Comedero. San Salvador de Jujuy, EDIUNJu.

BERGESIO, L., GOLOVANEVSKY, L. y MARCOLERI, M. E. (2009A). "Privatizaciones y mercado de Trabajo: La venta de empresas públicas en Jujuy y sus consecuencias sobre el empleo" en Lagos, M. (dir.), Jujuy bajo el signo neoliberal. Política sociedad y cultura en la 
década del noventa. San Salvador de Jujuy, EDIUNJu.

BERMAN, M. (2011 [1988]). Todo lo sólido se desvanece en el aire. La experiencia de la modernidad. España, Siglo XXI Editores.

BIDASECA, K. (2011). “"Mujeres blancas buscando salvar a mujeres color café': desigualdad, colonialismo jurídico y feminismo postcolonial” en Andamios, 8, 17.

BLANCHOT, M. (2002). La comunidad inconfesable. España, Editora Nacional.

BOLLE, W. (2008). "Metrópolis y megaciudades: sobre el ordenamiento del saber en los Pasajes de Walter Benjamin” en Buchenhorst, R. y Vedda, M. (eds.), Observaciones urbanas: Walter Benjamin y las nuevas ciudades. Buenos Aires, Gorla.

BRÁNCOLI, J. (comp.) (2010). Donde hay una necesidad, nace una organización. Surgimiento y transformación de las asociaciones populares urbanas. Buenos Aires, Ciccus.

BROWN, W. (1995). "Rights and losses" en States of injury. Power and freedom in late modernity. Estados Unidos, Princeton University Press.

BUCK-MORSS, S. (1995). Dialéctica de la mirada. Walter Benjamin y el proyecto de los pasajes. España, Visor, La balsa de Medusa.

BURGOS, R. (2014). Fútbol y política. El club Gimnasia y Esgrima y la construcción de una identidad jujeña (1975-2011). Tesis de Doctorado. Universidad Nacional de La Plata, La Plata.

BURGOS, R. y GARCÍA VARGAS, A. (2008). "El irrenunciable desafío de trabajar por Jujuy y su gente. Actores, cultura e identidad en el suplemento '50 aniversario de Pregón'” en Oficios Terrestres, 21.

BUTLER, J. (2011a). "Universalidades en competencia” en Butler, J., Laclau, E. Y Zizek, S. Contingencia, hegemonía, universalidad: diálogos contemporáneos en la izquierda. $2^{\circ}$ Ed. Buenos Aires, Fondo de Cultura Económica.

BUTLER, J. (2011b). "Replantear el universal: la hegemonía y los límites del formalismo” en 
Butler, J., Laclau, E. Y Zizek, S. Contingencia, hegemonía, universalidad: diálogos contemporáneos en la izquierda. $2^{\circ}$ Ed. Buenos Aires, Fondo de Cultura Económica.

BUTLER, J. (2009). Vida precaria. El poder del duelo y la violencia. Buenos Aires, Paidós.

BUTLER, J. (2008). Cuerpos que importan. Sobre los limites materiales y discursivos del sexo. Buenos Aires, Paidós.

BUTLER, J. (2007). El género en disputa. El feminismo y la subversión de la identidad. España, Paidós.

BUTLER, J. (2005). Deshacer el género. México, Una Pluma.

BUTLER, J. (1993). "Imitation and gender insubodination" en Abelove, H., Barale, M. y Halperin, D. (eds.), The lesbian and gay studies. Estados Unidos, Routledge.

BUTLER, J. y SPIVAK, G. (2009). ¿Quién le canta el Estado-Nación? Lenguaje, política y pertenencia. Buenos Aires, Paidós.

CAGGIANO, S. (2012). El sentido común visual. Disputas en torno a género, "raza” y clase en imágenes de circulación pública. Buenos Aires, Miño y Dávila.

CAGGIANO, S. (2005). Lo que no entra en el crisol: inmigración boliviana, comunicación intercultural y procesos identitarios. Buenos Aires, Prometeo libros.

CAGgianO, S., et. al. (2012). Racismo, violencia y política. Pensar el Indoamericano dos años después. Los Polvorines, Universidad Nacional de General Sarmiento.

CANETTI, E. (2010). Masa y poder. $1^{\circ}$ Ed., $6^{\circ}$ Reimpr. España, Alianza/Muchnik.

CANGI, A. (2013, septiembre). Del reparto de lo sensible. Elementos estéticos y políticos para una nueva arqueología del presente. Seminario de doctorado. FPyCS-UNLP. Apuntes de clase.

CARLI, S. (2000). "Los niños entre los derechos y la política. Peronismo, Pedagogía y transformaciones sociales (1945-1955)" en Niñez, pedagogía y política. Transformaciones de 
los discursos acerca de la infancia en la historia de la educación argentina entre 1880 y 1995. Buenos Aires, Miño y Dávila.

CARLI, S. (comp.) (1999). De la familia a la escuela. Infancia, socialización y subjetividad. Buenos Aires, Santillana.

CARMAN, M. (2011). Las trampas de la naturaleza: medioambiente y segregación en Buenos Aires. Buenos Aires, Fondo de Cultura Económica.

CARMAN, M. (2006). Las trampas de la cultura: Los 'intrusos' y los nuevos usos del barrio de Gardel. Buenos Aires, Paidós.

CASTELLS, M. (2004). La era de la información: economía, sociedad y cultura. Volumen II: El poder de la identidad. México, Siglo XXI Editores.

CASTILlO, F. (2007). Movimientos piqueteros: espacio, discurso y articulación de la subjetividad colectiva. Tesis de Licenciatura en Comunicación Social. Universidad Nacional de Jujuy, Jujuy.

CAUSA, A. y OJAM, J. (comps.) (2008). Mujeres piqueteras. Trayectorias, identidades, participación y redes. Buenos Aires, Baobab.

CHANT, S. (2003). Nuevas contribuciones al análisis de la pobreza: desafios metodológicos y conceptuales para entender la pobreza desde una perspectiva de género. Chile, Cepal.

CHEJTER, S. (1996). "Los setenta” en Travesía, Feminismo por feministas, 5.

CHEN, N. (1992). “"Speaking nearby’ a conversation with Trinh T. Minh-Ha” en Visual Anthropology Review, 8, 1.

COLECTIVO JUGUETES PERDIDOS (2011). Por atrevidos. Politizaciones en la precariedad. Buenos Aires, Tinta Limón.

COLECTIVO SIMBIOSIS, COLECTIVO SITUACIONES (2011). De chuequistas y overlockas. Una discusión en torno a los talleres textiles. Buenos Aires, Tinta Limón. 
COPI (2000 [1969]). Eva Perón. Buenos Aires: Adriana Hidalgo Editora.

CORTÉZ, P., GAONA, M. y LÓPEZ, A. (2010). "De la olla al fratacho: la participación de las mujeres en las cooperativas de construcción de viviendas en la Tupac Amaru-CTA" en García Vargas, A. (comp.), Ciudad. San Salvador de Jujuy como texto. Jujuy, EdiUnju.

CROSS, C. y FREYTES FREY, A. C. (2007). "Movimientos piqueteros: tensiones de género en la definición del liderazgo" en Argumentos. 20, 55.

CURIEL, O. (2011) "El regimen heterosexual y la nación. Aportes del lesbianismo feminista a la antropología" en Bidaseca, K. y Vazquez Lava, V (comps.), Feminismos y poscolonialidad. Descolonizando el feminismo desde y en América Latina. Buenos Aires, Ediciones Godot.

DE CERTEAU, M., GIARD, L. y MAYOL, P. (2000). A invenção do cotidiano. Tomo II: Morar, cozinhar. $3^{\circ}$ Edición. Brasil, Vozes.

DELAMATA, G. (2004). Los barrios desbordados: las organizaciones de desocupados del Gran Buenos Aires. Buenos Aires, EUDEBA.

DELFINO, S. (2012). Seminario de doctorado "Prácticas y saberes de la comunicación". Universidad Nacional de La Plata. Apuntes de clase.

DELEUZE, G. y GUATTARI, F. (2004). "Introducción: Rizoma” en Mil mesetas: capitalismo y esquizofrenia. $6^{\circ}$ Ed. España, Pre-textos.

DELFINO, S. (1998). "Desigualdad y diferencia: retóricas de identidad en la crítica de la cultura", en Estudios, 7-8.

DELFINO, S. Y FORASTELLI, F. (2012). “Activismo LGBT: temporalidades y escenas desde las luchas políticas de identidad de géneros" en De Signis: "Estudios queer. Semióticas y políticas de la sexualidad", 19.

DERRIDÁ, J. y DUFOURMANTELLE, A. (2000). La hospitalidad. Buenos Aires, Ediciones de La Flor. 
DI MARCO, G. (2011). El pueblo feminista. Movimientos sociales y lucha de las mujeres en torno a la ciudadanía. Buenos Aires, Biblos.

DI MARCO, G. (2003). "Movimientos sociales emergentes en la sociedad argentina y protagonismo de las mujeres". Trabajo Presentado en el VI Congreso Nacional de Ciencia Política de la Sociedad Argentina de Análisis Político (SAAP). Rosario.

DIMRI, J. (2012). "Images and representation" en Images and representation of the rural woman. A study of the selected novels of Indian women writers. India, Indian Institute of Advanced study.

DRI, R. (comp.) (2008). Movimientos Sociales. La emergencia del nuevo espíritu. Buenos Aires, Nuevos Tiempos.

EROLES, C. (2009). Familia, democracia y vida cotidiana. La(s) familia(s) en la gestación de movimientos sociales. Buenos Aires, Espacio.

ESPEJO, M (2006). “Introducción: la memoria recobrada” en Teruel A. y Lagos, M. (dir.), Jujuy en la historia. De la colonia al siglo XX. San Salvador de Jujuy, EDIUNJU.

FEMENÍAS, M. L. (2013). "Presentación: los caminos de la 'diferencia"” en Guerra, L. y Scirotino, M. L., Volver a los setenta. El feminismo italiano de la diferencia sexual. La Plata, EDULP.

FEMENÍAS, M. L. (2007). El género del multiculturalismo. Buenos Aires, Universidad Nacional de Quilmes.

FERNÁNDEZ, A. M. y colaboradores (2011). Política y subjetividad: asambleas barriales y fábricas recuperadas. $3^{\circ}$ Ed. Buenos Aires, Biblos.

FERNÁNDEZ RETAMAR, R. (1971). Calibán. Apuntes sobre la cultura en nuestra América. México, Diógenes.

FERRARA, F. (2003). Más allá de los cortes de ruta: la lucha por una nueva subjetividad. 
Buenos Aires, La rosa blindada.

FERRER, C. (2005). Mal de ojo. El drama de la mirada. Buenos Aires, Colihue.

FICOSECO, V. (2014). Experiencias, virtualidad y género. Usuarias del entorno virtual de aprendizaje de la Universidad Nacional de la Patagonia Austral, Unidad Académica San Julián. Tesis de Doctorado. Universidad Nacional de La Plata, La Plata.

FICOSECO, V. (2007). La construcción de la imagen de la mujer en la prensa gráfica de Jujuy durante la Fiesta Nacional de los Estudiantes. Tesis de Licenciatura. Universidad Nacional de Jujuy, Jujuy.

FICOSECO, V. y GAONA, M. (2014). "Orgullo y Dignidad. Repertorios del Reconocimiento y la Visibilización LGBT en Jujuy". Trabajo presentado en el Congreso Pre-Alas Patagonia 2014. Universidad Nacional de la Patagonia Austral. Calafate.

FICOSECO, V. y GAONA, M. (2013). "Preámbulo para las lecturas y reflexiones acerca del espacio. Lo construido en el relato" en Question, 1, 38.

FIGARI, C. (2009). Eróticas de la disidencia en América Latina. Brasil, siglos XVII a XX. Buenos Aires, CICCUS, CLACSO.

FORNI, P. y CATRONUOVO, L. (comps.) (2014). Ni piqueteros ni punteros. Organizaciones populares durante el kirchnerismo. La Plata, EDULP.

FOUCAULT, M. (2014). Historia de la sexualidad: la voluntad de saber. Buenos Aires, Siglo XXI Editores.

FOUCAULT, M. (2002). La arqueología del saber. Buenos Aires, Siglo XXI Editores.

FOURNIER, M. J. M. (2002). "Ordres et désordres dans les villes argentines, l'exemple de Alto Comedero, San Salvador de Jujuy" en Annales de Géographie, 624.

FRASER, N. (1993). "Repensar el ámbito público: una contribución a la crítica de la democracia realmente existente" en Debate Feminista, 7, 4. 
FREDERIC, S. (2004). Buenos vecinos, malos políticos: moralidad y política en el Gran Buenos Aires. Buenos Aires, Prometeo Libros.

FREITAG, S. (2012). Teorías da cidade. Brasil, Papirus.

FREUD, S. (2013 [1921]). Psicología de las masas y análisis del yo. Francia, VF Éditions.

GAONA, M. (2014a). "Hacerse el indio. Repertorios estratégicos de visibilidad para demandar" en Amerika, 11.

GAONA, M. (2014b). "Tripear por San Salvador de Jujuy. La ciudad mirada desde una web de turistas y viajeros" en Question 1, 44.

GAONA, M. (2014c). "De la constitución de una jujeñidad hegemónica" Trabajo presentado en el Congreso Pre-Alas Patagonia 2014. Universidad Nacional de la Patagonia Austral. Calafate.

GAONA, M. (2013). "Fragmentos potentes. Lecturas diversas en las intersecciones de la pluralidad urbana jujeña" en Actas digitales de las III Jornadas de becarios y tesistas. Bernal, Universidad Nacional de Quilmes.

GAONA, M. (2011). Vida cotidiana y relaciones familiares en el barrio Tupac Amaru de San Salvador de Jujuy. Tesis de Licenciatura en Comunicación Social. Universidad Nacional de Jujuy, Jujuy.

GAONA, M. y FICOSECO, V. (2014). "La mirada de la investigadora. Sentido común académico, reflexión epistemológica y práctica feminista" en Temas de Mujeres, 10.

GAONA, M. y FICOSECO, V. (2012). "La jujeñidad cuestionada: acciones colectivas que desafían las normas y los márgenes" en Question, 1, 35.

GAONA, M y LÓPEZ, A. (2013). Género, comunicación y cultura. En dos organizaciones sociales de San Salvador de Jujuy. Jujuy, Ediunju.

GAONA, M y LÓPEZ, A. (2009). “Ciudad sitiada: caos, temor e incertidumbre'. 
Manifestaciones, imagen e imaginarios sociales". Trabajo presentado en la XI Jornada Nacional de jóvenes investigadores de la Comunicación, VI Encuentro Nacional de Investigadores de la Comunicación y III Expocom Bolivia. Bolivia.

GARCÍA LINERA, A. (2012). Las tensiones creativas de la revolución. La quinta fase del proceso de cambio en Bolivia. Buenos Aires, Ediciones Luxemburg.

GARCÍA LINERA, A. (2009). La potencia plebeya: acción colectiva e identidades indígenas, obreras y populares en Bolivia. Colombia, Siglo del Hombre Editores y Clacso.

GARCÍA LINERA, A. (2005). "La lucha por el poder en Bolivia”, en Horizontes y límites del Estado y el poder. Bolivia, Muela del Diablo.

GARCÍA LINERA, A. (2004). Sociología de los movimientos sociales en Bolivia. Bolivia, Diakonia, Oxfam y Plural.

GARCÍA MORITÁN, M. (2010). "De la cuadrícula de control a la gran ciudad” en García Vargas, A. (comp.), Ciudad. San Salvador de Jujuy como texto. San Salvador de Jujuy, EdiUnju.

GARCÍA MORITÁN, M. y ECHENIQUE, M. (1990). “Lógica de la localización de los pobres urbanos en Jujuy" en Cuadernos, 2.

GARCÍA VARGAS, A. (2011). "Mapas clásicos y parecidos de familia en la producción comunicacional latinoamericana sobre ciudades" en Cuadernos, 39.

GARCÍA VARGAS, A. (2010a). "San Salvador de Jujuy: una, otra, esta ciudad". En A. GARCIA VARGAS (comp.), Ciudad. San Salvador de Jujuy como texto. Jujuy, Ediunju.

GARCÍA VARGAS, A. (2010b). “Tan lejos, tan cerca...' Medios masivos e inmigración boliviana en San Salvador de Jujuy" en Con-Sciencias Sociales, 2.

GARCÍA VARGAS, A. (2009). “Geografías del poder. Comunicación transnacional y estudios interculturales en la periferia globalizada" en Memoria Encuentro Internacional Comunicación 
y Cultura “Interculturalidad, globalización y comunicación”. La Paz, Fundación Visión Cultural.

GARCÍA VARGAS, A. (2006). "En construcción. Geografías del poder y sentidos del lugar en San Salvador de Jujuy" en UNIRev Actas del VII Congreso ALAIC y VIII Congresso Latinoamericano de Pesquisadores de Comunicaçao. São Leopoldo, Rio Grande do Sul, Brasil.

GARCÍA VARGAS, A. (2004). “Traducciones. Multiculturalidad, espacio físico y espacio social en la patrimonialización de San Salvador de Jujuy durante la década de 1990" en Ponencias 70 años de Periodismo y Comunicación en América Latina, La Plata, Facultad de Periodismo y Comunicación Social, Universidad Nacional de La Plata.

GARCÍA VARGAS, A. (2003). "La iconicidad como estrategia metodológica: mapas y planos de San Salvador de Jujuy" en Signo y Pensamiento, 22, 43.

GARCÍA VARGAS, A. (2002). “Acción colectiva, visibilidad y espacio público en la construcción de la ciudadanía/Los cortes de puentes de mayo del '97 en San Salvador de Jujuy" en Revista Latina de Comunicación Social, 35.

GARCÍA VARGAS, Alejandra (2000) "San Salvador de Jujuy: Distribución en el espacio y posibilidades de acceso a instituciones sanitarias". En: Informe Argentino sobre Desarrollo Humano. Buenos Aires: PNUD / Senado de la Nación Argentina.

GARCÍA VARGAS, A. (1999). "Señores, el Mercado es la cara de cada pueblo. El uso de la Banca XIII en relación con el conflicto por la privatización del Mercado Central Municipal de San Salvador de Jujuy", en Actas de la Tercer Reunión de Antropología del MERCOSUR (III RAM), Posadas, Universidad Nacional de Misiones.

GARCÍA VARGAS, A., ARRUETA, C. Y BRUNET, M. (2009). “Medios masivos: tramas y complicidades en Jujuy. Una mirada desde la década del 90” en Lagos, M. (dir.), Jujuy bajo el signo neoliberal. Política sociedad y cultura en la década del noventa. San Salvador de Jujuy, EDIUNJu. 
GARCÍA VARGAS, A., GAONA, M. y LÓPEZ, A. (2012). "Espacio físico, espacio social y espacio mediático: territorios y sentidos de ciudad en San Salvador de Jujuy (Argentina)" en Actas digitales del XI Congreso Latinoamérica de Investigadores de la Comunicación. Universidad Nacional de la República, Montevideo. Uruguay.

GARDELLA, M. E. (2010). "La mirada cultural en las prácticas de comunicación. El caso Tucumán Danza”. Mimeo.

GEERTZ, C. (1989). "Estar allí. La antropología y la escena de escritura" en El antropólogo como autor. Buenos Aires, Paidós.

GELDSTEIN, M. R. (1997). Mujeres jefas de hogar: familia, pobreza y género. Unicef Argentina.

GIDDENS, A. (1993). Las nuevas reglas del método sociológico. Crítica positiva de las sociologías interpretativas. $1^{\circ}$ Reimpr. Buenos Aires, Amorrortu.

GINZBURG, C. (1999). “Indicios. Raíces de un paradigma de inferencias indiciales” en Mitos, emblemas, indicios. Morfología e historia. España, Gedisa.

GONZÁLEZ, H., LÓPEZ, M. P. y SCOLNIK, S. (2011). "Alejandro Kaufman: 'Se ha alcanzado un techo en la posibilidad de desarticular críticamente los discursos dominantes" en La Biblioteca, 11.

GONZÁLEZ CASANOVA, P. (comp.) (1985). Historia política de los campesinos latinoamericanos 3. México, Siglo XXI Editores.

GORELIK, A. (1998). La grilla y el parque. Espacio público y cultura urbana en Buenos Aires, 1887-1936. Bernal, EDUNQ.

GRAMSCI, A. (2011). "La ciencia y las ideología 'científicas"”, "Concepto de 'ideología", "Conexión entre el sentido común, la religión y la filosofía" en Antología. Buenos Aires, Siglo XXI Editores. 
GRIMSON, A. (2009). "Introducción: clasificaciones espaciales y territorialización de la política en Buenos Aires" en GRIMSON, A. FERRAUDI CURTO, M. y SEGURA, R. (comps.), La vida política en los barrios populares de Buenos Aires. Buenos Aires, Promteo Libros.

GRIMSON, A. FERRAUDI CURTO, M. y SEGURA, R. (comps.) (2009). La vida política en los barrios populares de Buenos Aires. Buenos Aires, Promteo Libros.

GROSSBERG, L. (2006). "Stuart Hall sobre raza y racismo: estudios culturales y la práctica del contextualismo" en Tabula Rasa, 5.

GRÜNER, E. (1995). “Foucault: una política de la interpretación” en Foucault, M. Nietzsche, Freud, Marx. Buenos Aires, El cielo por asalto.

GRUPPI, L. (1978). El concepto de Hegemonía en Gramsci. México, Ediciones de Cultura Popular.

GUATTARI, F. y ROLNIK, S. (2006). Micropolítica. Cartografias del deseo. Brasil, Editora Vozes.

GUBER, R. (2005 [1991]). El salvaje metropolitano. Reconstrucción del conocimiento social en el trabajo de campo. $1^{\circ}$ Reimpr. Buenos Aires, Gedisa.

GUBER, R. (2001). La etnografía. Método, campo y reflexividad. Colombia, Norma.

HALL, S. (2010a). ¿Qué es lo negro en la cultura popular negra? En E. Restrepo, C. Walsh, y V. Vich. (Eds.). Sin garantías: trayectorias y problemáticas en estudios culturales. Bogotá: Envión Editores.

HALL, S. (2010b). La cultura, los medios de comunicación y el 'efecto ideológico'. En Restrepo, E., Walsh, C. y Vich, V. (eds.), Sin garantías: trayectorias y problemáticas en estudios culturales. Bogotá: Envión Editores. 
HALL, S. (1997). Representation. Cultural representations and signifying practices. Editado por Stuart Hall.

HAMMERSLEY, M. y ATKINSON, P. (1994). Etnografía. Métodos de investigación. España, Paidós.

HARAWAY, D. (2004). “Testigo_Modesto@Segundo_Milenio” en The Haraway Reader. Traducción de Pau Pitarch. Estados Unidos, Routledge.

HARAWAY, D. (1999). "Las promesas de los monstruos: una política regeneradora para otros inapropiados/bles" en Política y Sociedad, 30.

HARAWAY, D. (1991). Ciencia, cyborgs y mujeres. La reinvención de la naturaleza. España, Cátedra.

HARDING, S. (1998). “Existe un método feminista?” En Bartra, E. (comp.), Debates en torno a una metodología feminista. México, UAM.

HARDING, S. (1993). "Rethinking standpoint epistemology: What is 'strong objectivity'” en Alcoff, L. y Potter, E. (eds.). Feminist epistemologies. Estados Unidos, Routledge.

HARDING, S. (1993). "Rethinking standpoint epistemology: What is 'strong objectivity"” en Alcoff, L. y Potter, E. (eds.). Feminist epistemologies. Estados Unidos, Routledge.

HARDT, M. y NEGRI, A. (2012). Declaration. Estados Unidos, Agro-Navis.

HARDT, M. y NEGRI, A. (2005). Imperio. España, Paidós Ibérica.

HARVEY, D. (2014). “A liberdade da cidade” en MARICATO, E., et. al. (comps.), Cidades rebeldes: Passe livre e as manifestações que tomaram as ruas do Brasil. Brasil, Tinta Vermelha.

HARVEY, D. (2007). Espacios Del capital. Hacia una geografía crítica. España, Akal.

JAY, N. (1981). "Gender and dichotomy” en Feminist studies, 7. 
JEREZ, M. (e. p.). "El problema de la vivienda en San Salvador de Jujuy en la primera mitad del siglo XX" en García Vargas, A. (comp.), Territorios y sentidos de ciudad. San salvador de Jujuy, la capital provincial. San Salvador de Jujuy, EDIUNJu.

KARASIK, G. (2005). Etnicidad, cultura y clases sociales. Procesos de formación histórica de la conciencia colectiva en Jujuy, 1970-2003. Tesis de doctorado, FFyL-UNT.

KARASIK, G. (1994). "Plaza grande y plaza chica: etnicidad y poder en la Quebrada de Humahuaca" en Karasik, G. (comp.), Cultura e identidad en el noroeste argentino. Buenos Aires, Centro Editor de América Latina.

KAUFMAN, A. (2014). “Animales sueltos” en Voces en el Fénix, 32.

KAUFMAN, A. (2012). La pregunta por lo acontecido. Ensayos de anamnesis en el presente argentino. Lanús, Ediciones La Cebra.

KAUFMAN, A. (2012, noviembre). Taller de tesis I de doctorado. FPyCS-UNLP. Apuntes de clase.

KESSLER, G. SVAMPA, M. y GONZÁLEZ BOMBAL, I. (comps.) (2010). Reconfiguraciones del mundo popular. El conurbano bonaerense en la postconvertibilidad. Buenos Aires, Prometeo Libros.

KINDGARD, F. (2009). "Los conflictos sociales bajo la política neoliberal" en Lagos, M. (comp.), Jujuy bajo el signo neoliberal. Política, sociedad y cultura en la década del noventa. $2^{\circ}$ Ed. San Salvador de Jujuy, EdiUnju.

KINDGARD, F. y GÓMEZ, E. (2000). "Los cortes de ruta en la provincia de Jujuy. Mayo/Junio de 1997". Documento de trabajo N¹5. Programa de investigación sobre el Movimiento de la Sociedad Argentina. Mimeo.

KOROL, C. (comp.) (2009). Criminalización de la pobreza y de la protesta social. Buenos Aires, Editorial El Colectivo y América Libre. 
KRISTEVA, J. (1981). Semiótica I. $2^{\circ}$ Ed. España, Ed. Fundamentos.

LACLAU, E. (2011). La razón populista. $1^{\circ}$ Ed., $6^{\circ}$ Reimp. Buenos Aires, Fondo de Cultura Económica.

LACLAU, E. (2007). "La deriva populista y la centroizquierda latinoamericana" en Nueva Sociedad, 205.

LACLAU, E. y MOUFFE, CH. (1987). Hegemonía y estrategia socialista. Hacia una radicalización de la democracia. España, Siglo XXI Editores.

LAGOS, M. y GUTIÉRREZ, M. (2009). "La década del menemismo y la ingobernabilidad en Jujuy. Nación, región y provincia en los noventa" en Lagos, M. (comp.), Jujuy bajo el signo neoliberal. Política, sociedad y cultura en la década del noventa. $2^{\circ}$ Ed. Jujuy, EdiUnju.

LAGOS, M. y GUTIÉRREZ, M. (2006). "Dictadura, democracia y políticas neoliberales. 1976-1999” en Teruel A. y Lagos, M. (dir.), Jujuy en la historia. De la colonia al siglo XX. San Salvador de Jujuy, EDIUNJU.

LAVANDERA, P. y MAGLIONI, C. (2010). "Caracterización de las organizaciones" en Bráncoli, J., Donde hay una necesidad, nace una organización. Surgimiento y transformación de las asociaciones populares urbanas. Buenos Aires, Ciccus Ediciones.

LE BON, G. (2000 [1895]). Psicología de las masas. $5^{\circ}$ Ed. España, Morata.

LEAVI, C. (2013). Los sentidos de la justicia: Juicio por genocidio y desaparición de López en la ciudad de La Plata. Tesis de Doctorado. Universidad Nacional de La Plata, La Plata.

LEFEBVRE, H. (1991 [1974]). "Social Space" en The Production of Space. Gran Bretaña, Antropos.

LEFF, E. (2006). "La ecología política en América Latina. Un campo en construcción” en Alimonda, H. (comp.), Los tormentos de la materia: aportes para una ecología política latinoamericana. Buenos Aires, CLACSO. 
LOBATO M. Z. y SURIANO, J. (2003). La protesta social en Argentina. Buenos Aires, Fondo de Cultura Económica.

LÓPEZ, A. (2011). La participación de las mujeres en el movimiento social y cultural Tupaj Katari. Tesis de Licenciatura. Universidad Nacional de Jujuy, Jujuy.

LÓPEZ, M. P. (2012). "Formas y figuras del racismo" en CAGGIANO, S., et. al. (2012). Racismo, violencia y política. Pensar el Indoamericano dos años después. Los Polvorines, Universidad Nacional de General Sarmiento.

LÓPEZ, M. P. (1997). Mutantes. Trazos sobre los cuerpos. Buenos Aires, Colihue.

LORDE, A. (1984). “Age, race, class, and sex: women redefining difference” en Sister Outsider, 116.

MANZANO, V. (2013). La política en movimiento. Movilizaciones colectivas y políticas estatales en la vida de Gran Buenos Aires. Rosario, Prohistoria Ediciones.

MARCUS, G. (2001). "Etnografía en/del sistema mundo. El surgimiento de la etnografía multilocal" en Alteridades, 11, 22.

MASSETTI, A. (2004). Piqueteros: protesta social e identidad colectiva. Buenos Aires, Editorial de las Ciencias.

MASSEY, D. (2012). "Un sentido global de lugar” en Albert, A. y Beach, N. (comp.), Doreen Massey. Un sentido global del lugar. España, Icaria.

MASSEY, D. (2005). For Space. Gran Bretaña, Sage Publications.

MASSEY, D. (1994). Space, place and gender. Estados Unidos, Minnesota Press.

MATA, M. C. (2009) "Comunicación comunitaria en pos de la palabra y la visibilidad social” en Área de Comunicación Comunitaria (comp.), Construyendo comunidades... Reflexiones actuales sobre la comunicación comunitaria. Buenos Aires, La Crujía y Universidad Nacional de Entre Ríos. 
MATTIO, E. (2009). “¿Esencialismo estratégico? Un examen crítico de sus limitaciones políticas" en Construyendo nuestra interculturalidad, 5, 4.

MAYA, R. (2014). La construcción de la figura del gaucho en la radio de San Salvador de Jujuy. Los casos de los programas "Tradiciones gauchas" y "El orejano". (Tesis de licenciatura. Universidad Nacional de Jujuy, Jujuy.

MELLUCI, A. (1999). Acción colectiva, vida cotidiana y democracia. México, El Colegio de México, Centro de Estudios Sociológicos.

MERKLEN, D. (2005). Pobres ciudadanos: las clases populares en la era democrática. Argentina, 1983-2003. Buenos Aires, Gorla.

MEZZINI, M., LABECKY, B. y BRÁNCOLI, J. (2010). "Las organizaciones comunitarias y su vínculo con el Estado" en Bráncoli, J., Donde hay una necesidad, nace una organización. Surgimiento y transformación de las asociaciones populares urbanas. Buenos Aires, Ciccus Ediciones.

MINH-HA, T. (1991). "The totalizing quest of meaning" en When the moon waxes red: representation, gender at cultural politics. Estados Unidos, Routledge.

MOHANTY, Ch. y ALEXANDER, J. (2004). "Genealogías, legados, movimientos" en bell hooks, et. al., Otras Inapropiables. Feminismos desde las fronteras. España, Traficantes de sueños.

MOSCOVICH, L. (2009). "Fronteras entre la participación y la política. Estudio de las relaciones entre los gobiernos subnacionales y las organizaciones sociales con financiamiento federal en la Argentina". Trabajo presentado en el XXI Congeso Internacional de Ciencia Política. Chile.

MTD SOLANO y COLECTIVO SITUACIONES (2002). Hipótesis 891. Más allá de los piquetes. Buenos Aires, Tinta Limón Ediciones.

MUJERES CREANDO (2005). La virgen de los deseos. Buenos Aires, Tinta Limón Ediciones. 
NIETZSCHE, F. (2011 [1887]). La genealogía de la moral. $1^{\circ}$ Ed., $1^{\circ}$ Reimpr. Buenos Aires, R.P. Centro Editor de Cultura, Libertador.

NUIN, S. (2008). Dibujando fuera de los márgenes. Movimientos sociales en América Latina. Entrevista a Raúl Zibechi. Buenos Aires, La Crujía.

OLMEDO, J. (1998). El perro Santillán en Jujuy. Diálogos con Jesús Olmedo. Buenos Aires, Ediciones Populares.

ORTNER, B. (1974). "Is female to male as nature is to culture?" en ROSALDO, M. y Lamphere, L. (eds), Woman, culture, and society. Estados Unidos, Stanford University Press.

PAREDES, J. y GALINDO, M. (1992). “¿Y si fuésemos una espejo de la otra?: la construcción de nuestra identidad" en ¿Y si fuésemos una espejo de la otra?: por un feminismo no racista. Bolivia, Ediciones Gráficas.

PARK, R. E. (1999). La ciudad y otros ensayos de ecología urbana. España, Ediciones del Serbal.

PARTENIO, F. (2008). Género y participación política: Los desafios de la organización de las mujeres dentro de los movimientos piqueteros en Argentina. Informe final del concurso: Las deudas abiertas en América Latina y el Caribe. Programa Regional de Becas CLACSO.

PAZ FRONTERA, A. (2013). Una excursión a los mapunkies. Buenos Aires, Pánico el pánico.

PERLONGUER, N. (2008). Prosa plebeya. Ensayos 1980-1992. Buenos Aires, Colihue.

PLATERO, R. L. (2009). "La masculinidad de las biomujeres: marimachos, chicazos, camioneras y otras disidentes" en Trasversales, 17.

POOLE, D. (2000). Visión, raza y modernidad. Una economía visual del mundo andino de imágenes. Perú, Sur, Casa de Estudios en el Socialismo.

PRECIADO, B. (2010). Pornotopía. Arquitectura y sexualidad en 'Playboy'durante la guerra fría. España, Anagrama. 
PRECIADO, B. (2007). "Devenir bollo-lobo o cómo hacerse un cuerpo queer a partir de $E l$ pensamiento heterosexual" en Córdoba, D., Saéz, J. y Vidarte, P. (comps.), Teoría Queer. Politicas Bolleras, Maricas, Trans, Mestizas. $2^{\circ}$ Ed. España, Egales.

PRECIADO, B. (2003). "Multitudes queer. Notas para una política de los 'anormales'” En Multitudes, 12.

RANCIERE, J. (2014). El reparto de lo sensible. Estética y política. Buenos Aires, Prometeo Libros.

RAPISARDI, F. y BELLUCCI, M. (2002). "Identidad: diversidad y desigualdad en las luchas políticas del presente" en Borón, A. y De Vita, A. (comps.), Teoría y filosofía política. La recuperación de los clásicos en el debate latinoamericano. Buenos Aires, CLACSO.

REGUILLO, R. (2007). “Ciudad y Comunicación. Densidades, ejes y niveles” en Diálogos de la comunicación, 47.

RETAMOZO, M. (2009). Movimientos sociales. Subjetividad y acción de los trabajadores desocupados en Argentina. México, FLACSO.

RICH, A. (2003). Heterosexualidad obligatoria y existencia lesbiana. Bs. As., Libros de la mala semilla.

RICHARD, N. (2001). Residuos y metáforas (Ensayos de crítica cultural sobre el Chile de la Transición). Chile, Cuarto Propio.

RIVERA CUSICANQUI, S. (2012, septiembre). Charla abierta con Silvia Rivera Cusicanqui. Organizada por el Área de Estudios Interdisciplinarios en Educación Aborigen del Departamento de Educación de la Universidad Nacional de Luján. Buenos Aires. Apuntes personales.

RIVERA CUSICANQUI, S. (2010). Ch'ixinakax utxiwa: Una reflexión sobre prácticas y discursos descolonizadores. Buenos Aires, Tinta Limón Ediciones. 
RIVERA CUSICANQUI, S. (2003). Oprimidos pero no vencidos. Bolivia, AruwiyiriYachaywasi.

RIVERA CUSICANQUI, S. (1983). "Luchas campesinas contemporáneas en Bolivia: el movimiento 'katarista': 1970-1980" en Zavaleta Mercado, R. (comp.): Bolivia hoy. México, Siglo XXI Ediciones.

RODRÍGUEZ ALZUETA, E. (2014). Temor y control. La gestión de la inseguridad como forma de gobierno. Buenos Aires, Futuro Anterior.

RODRÍGUEZ ALZUETA, E. (2007). Vida lumpen. Bestiario de la multitud. La Plata, EDULP.

RODRÍGUEZ BLANCO, M. (2011). "Participación ciudadana no institucionalizada, protesta y democracia en Argentina" en Íconos, 40.

RODRÍGUEZ BLANCO, M. (2002). La parte de los que no tienen parte. La dimensión simbólica y política de las protestas sociales: la experiencia de los piqueteros en Jujuy. Buenos Aires, Centro Cultural de la Cooperación.

ROMÁN VELÁSQUEZ, P. y GARCÍA VARGAS, A. (2008). “'Hay que traer espacio a la vida'. Entrevista con Doreen Massey" en Signo y Pensamiento, 27, 53.

ROMERO, J. L. (2010). Latinoamérica. La ciudad y las ideas. $3^{\circ}$ Ed. Buenos Aires, Siglo XXI Editores.

ROSALDO, R. (1989). Cultura y verdad. Nueva propuesta de análisis social. México, Grijalbo.

ROTONDI, G. (2000). Pobreza y Masculinidad. El urbano marginal. Buenos Aires, Espacio Editorials.

RUSSO, S. (2010). Milagro Sala. Jallalla. La Tupac, utopía en construcción. Buenos Aires, Colihue.

SAID, E. (1996). Representaciones del Intelectual. España, Paidós. 
SARTRE, J. P. (1948). Reflexiones sobre la cuestión judia. Buenos Aires, Ediciones Sur.

SASSEN, S. (1999). The global city: New York, London, Tokyo. Gran Bretaña, Princeton University Press.

SCHUTTENBERG, M. (2011). "La reconfiguración de las identidades 'nacional populares'. Los puentes discursivos para la inserción de tres tradiciones políticas en el espacio 'transversal kirchnerista"” en Sociohistoria. Cuadernos del CISH, 28.

SCOTT, J. (1999 [1992]). “Experiencia” en Hiparquía, 10, 1.

SCOTT, J. (1993). "El género: una categoría útil para el análisis histórico”. En LAMAS, M. (comp.), El género: la construcción cultural de la diferencia sexual. México, PUEG.

SEGATO, R. (2013). La escritura en el cuerpo de las mujeres asesinadas en Ciudad Juárez. Buenos Aires, Tinta Limón.

SEGATO, R. (2012, junio). Las humanidades frente a los Derechos Humanos. Seminario de doctorado. FPyCS-UNLP. Apuntes de clase.

SEGATO, R. (2011). "Género y colonialidad: en busca de claves de lectura y de un vocabulario estratégico descolonial" en Bidaseca, Karina y Vazquez Laba, Vanesa (comp.): Feminismo y Poscolonialidad. Descolonizando el feminismo desde y en América Latina. $2^{\circ}$ Ed. Buenos Aires, Ediciones Godot.

SEGATO, R. (2007). La nación y sus otros. Raza, etnicidad y diversidad religiosa en tiempos de políticas de la identidad. Buenos Aires, Prometeo Libros.

SEGURA, R. (2009). “'Si vas a venir a la villa, loco, entrá de otra forma'. Distancias sociales, límites espaciales y efectos de lugar en un barrio segregado del gran Buenos Aires" en GRIMSON, A. FERRAUDI CURTO, M. y SEGURA, R. (comps.), La vida política en los barrios populares de Buenos Aires. Buenos Aires, Promteo Libros. 
SENNET, R. (1997). Carne y piedra. El cuerpo y la ciudad en la civilización occidental. España, Alianza Editorial.

SILVEIRA, S. y CAMUSSO PINTOS, V. (2010). “Taller de Formación 'Jóvenes investigando jóvenes'. Programa “Mujeres jóvenes en la Sociedad de la Información”. Aula Virtual Unidad Tres, Módulo Ocho: 'Trabajo y Empleo'" de Cátedra Regional UNESCO Mujer, Ciencia y Tecnología en América Latina.

SONTAG, S. (2008 [1966]). Contra la interpretación: y otros ensayos. Buenos Aires, Debolsillo.

SPIVAK, G. (2012). Otras Asias. España, Akal.

SPIVAK, G. (2011 [1988]). ¿Puede hablar el subalterno? Buenos Aires, Ed. Cuenco de Plata. SPIVAK, G. (1993). "In a word: Interview" en Outside in the teaching machine. Entrevista de Ellen Rooney. Estados Unidos, Routledge.

STEFANONI, P. (2012). “¿Y quién no querría ‘vivir bien’? Encrucijadas del proceso de cambio boliviano" en Crítica y Emancipación, 4, 7.

STEFANONI, P. y DO ALTO, H. (2006). Evo Morales de la coca al Palacio. Una oportunidad para la izquierda indígena. Bolivia, Malatesta.

SVAMPA, M. (2005). La sociedad excluyente. Buenos Aires, Taurus.

SVAMPA, M. (2001). Los que ganaron. La vida en los countries y barrios privados. Buenos Aires, Biblos.

SVAMPA M. y PEREYRA, S. (2009 [2003]). Entre la ruta y el barrio. La experiencia de las organizaciones piqueteras. $3^{\circ} \mathrm{Ed}$. Buenos Aires, Biblos.

TABBUSH, C. y CAMINOTTI, M. (e. p.). "Emociones en movimiento: Milagro Sala, la 'militante iracunda' del norte argentino" en Mora, 22. 
TABBUSH, C. y CAMINOTTI, M. (2015). "Tensiones entre igualdad de género y movimientos en la Argentina posneoliberal: acerca de la Organización Barrial Tupac Amaru (2003-2014)" en Perfiles Latinoamericanos, 23, 46.

TARDUCCI, M. (2014). "Hitos de la militancia lesbofeminista en Buenos Aires (1984-1995)" en Tarducci, M. (comp.), Feminismo, Lesbianismo y Maternidad en Argentina. Buenos Aires, Librería de Mujeres Editoras.

TARROW, S. (1997). El poder en movimiento. España, Alianza Editorial.

THOMPSON, K. (2014). Pánicos morales. Bernal, EDUNQ.

TILLY, CH. (2010). Los movimientos sociales, 1768 - 2009. Desde sus origenes a Facebook. España, Crítica.

TIQQUN (2013). Primeros materiales para una teoría de la jovencita. Hombres-máquina modo de empleo. Buenos Aires, Hekht Libros.

TOURAINE, A. (1997). ¿Podremos vivir juntos? Iguales y diferentes. Buenos Aires, Fondo de Cultura Económica.

VICEPRESIDENCIA DEL ESTADO PLURINACIONAL DE BOLIVIA (comp.) (2010). Pensando el mundo desde Bolivia. I Ciclo de Seminarios Internacionales. Bolivia.

VILLANUEVA, E. y MASETTI, A. (comps.) (2007). Movimientos sociales y acción colectiva en la Argentina de hoy. Buenos Aires, Prometeo Libros.

VIRNO, P. (2008). Gramática de la multitud. Para un análisis de las formas de vida contemporáneas. Buenos Aires, Colihue.

WACQUANT, L. (1999). Las cárceles de la miseria. Buenos Aires, Manantial.

WILLIAMS, R. (2009). Marxismo y Literatura. Traducción de Guillermo David. Buenos Aires, Los Cuarenta. 
WITTIG, M. (2006 [1992]). El pensamiento heterocentrado y otros ensayos. España, Egales.

YUVAL-DAVIS, N. (2003). "Nationalist projects and gender relations" en Narodna Umjetnost, 40, 1.

ZIBECHI, R. (2006). Dispersar el poder. Los movimientos como poderes antiestatales. Buenos Aires, Tinta Limón Ediciones. 
ANEXOS 